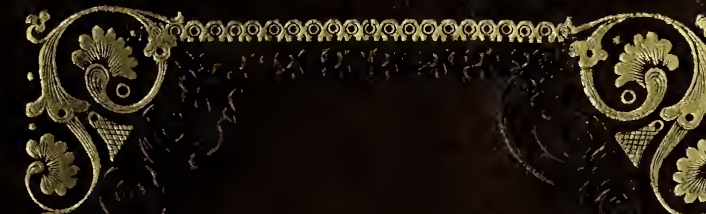

r.

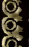

?

o

of 


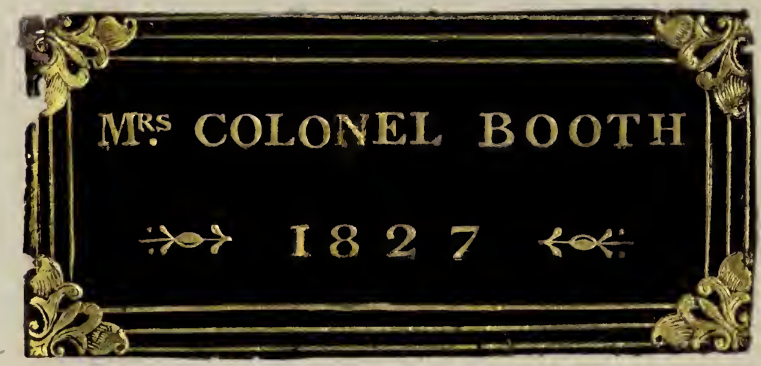




\section{Digitized by the Internet Archive}

in 2017 with funding from Getty Research Institute 




\section{THE}

\section{B RITISH}

\section{FLOW ER GA R D N ;}

CONTAINING

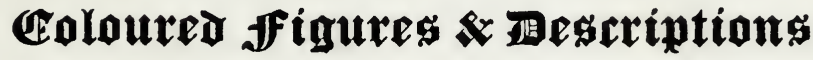

OF THE

MOST ORNAMENTAL \& CURIOUS

\section{HARDY HERBACEOUS PLANTS,}

INCLUDING

ANNUALS, BIENNIALS, \& PERENNIALS;

WITH THEIR

SCIENTIFIC AND ENGLISH NAMES;

BEST METHOD OF CULTIVATION AND PROPAGATION;

THE HEIGHTS THEY GENERALLY ATTAIN;

Or any other Information respecting them that may be considered useful or entertaining.

BY

ROBERT SWEET, F.L.S.

Author of Hortus Suburbanus Londinensis, Botanical Cultivator, Geraniacea, the British Warblers, \&c. \&c.

The Drawings by E. D. SMITH, F. L.S.

\section{VOLUME I.}

\section{LONDON:}

PUBLISHED FOR THE AUTHOR,

BY W. S IMPKIN A N D R. MARSHALL, STATIONERS'-HALL-COURT, LUDGATE-STREET.

1823 to 1825. 
TILUING, PRINTEI, CHELSEA. 


\section{BOOKS QUOTED.}

Act. Soc. Asiat. Asiatic Researches, or Transactions of the Society instituted in Bengal, 4 to. Calcutta, 1788 et seq. Adanson fam. Adanson (Michel.) Familles des Plantes, 2vol. 8vo. Paris, 1763 . Andrews's reposit. The Botanist's Repository for new and rare Plants. By Henry Andrews, 4to. London, 1797 et seq. All. pedem. Allioni (Carolus.) Flora Pedemontana, 3 vol. fol. Taurini, 1785. Barton $f$. amer. Barton's Flora of North America, 4to.

Besl. eyst. vern. ord. Besler (Basilius.) Hortus Eystettensis, 2 vol. fol. $N u$ remberg, 1612.

Bess. cat.h. crem. Besser (Wilib.) Catalogus horti Botanici Wolhyniensis Cremenici, 8vo. 1811-1816.

Bot. mag. Curtis (William.) The Botanical Magazine, 8vo. vol. 1 to 12, continued by Dr. J. Sims. London.

Bot. reg. Edwards (Sydenham.) The Botanical Register, descriptions by J. B. Ker, 8vo. London.

Brot. fl. lusit. Brotero (Felix Avellar.) Flora Lusitanica, 2 vol. 8 vo. Olissiponone, 1804.

Brown prodr. Brown (Robertus.) Prodromus floræ nova Hollandiæ, et Insulæ vall Diemen, vol. 1. 8vo. Londini, 1810.

Cavanill. ic. Cavanilles (Aut. Jos.) Icones et Descriptiones Plantarum quae aut sponte in Hispaniâ crescunt aut in loortis hospitantur, 6 vol. fol. Madriti. I. 1791. VI. 1800 .

Column. ecphr. Colımna (Fabius.) Minus cognitarum stirpium Ecphrasis, 4to. Roma, 1616.

Colv. cutal. A Catalogue of Plants, sold by Colvill and Son, Nursery and Seedsmen, King's-road, Chelsea, near London, 1821, $12 \mathrm{mu}$.

Colv. catal. ed. 2. A Catalogue of Plants sold by James Colvill, Nursery and Seedsmun. Second Edition, 1823, $12 \mathrm{mo}$.

Curtis magaz. see Bot. mag.

DC. Astrag. De Candolle (Augustin Pyramus.) Astragalogia, 1 vol. 4to. et fol. Paris, 1802.

DC. horl. monsp. Id. Catalogus plantarum horti botanici Monspeliensis addito observationum circa species novas aut non satis cognitas fasciculo, 1 vol. $8 \mathrm{vo}$. Monspelii, 1813.

DC. ic. gall, rar. Id. Icones Plantarum Galliæe rariorum, 1 vol. 4to. Paris, 1808.

DC. prodr. Id. Prodromus Systematis naturalis Regni Vegetabilis, vol. 1. 8vo. Parisiis, 1824.

DC. Reg. veg. syst. nut. Id. Regni Vege. tabilis Systema Naturale, vol. 1 et 2, 8vo. Parisiis, v. 1, 1818, v. 2, 1821.

DC. theor. Id. Théorie élémentaire de la Botanique, 1 vol. 8vo. Paris, 1813.

Deless. ic. sel. Delessert (Benj.) Icones selectæ plantarum in system. univers. descriptarum, 4to. Paris, fasc.1, 1820. fasc. 2,1823 .
Desfont. arb. Desfontaines (RenéLoniche.) Histoire des arbres et arbrisseaux qui peuvent être cultivés en pleine terre sur le sol de la France, 2 vol. 8vo. Paris, 1809.

Desf. atl. Id. Flora Atlantica, 2 vol. 4to. Paris, 1793 et 1799.

Dill elth. Dillenius (Joh.Jac.) Hortus elthamensis, 2 vol. fol. Londini, 1732.

Donn cant. Donn (James.) Hortus Cantabrigiensis, 8vo. Cambridge.

Don prodr. fl. nep. Don (David.) Prodromus Floræ Nepalensis, 12mo. Lon. dini, 1825.

Flor. peruv. Ruiz (Hippol.) et Pavon (Jos.) Flora Peruviana et Chilensis prodromus, sive novorum generum descriptiones et icones, fol. Madrid, 1794.

Gœrt. sem. Gærtner (Josephus.) De Fructibus et seminibus plantarum, 2 vol. 4to. Lipsia, 1788. II. Ibidem, 1791.

Gmel. sibir. Gmelin (Joh. Georg.) Flora Sibirica, 4 vol. 4 to. Petropoli, 1747 1769.

Gnu. fl. monsp. Gouan (Anton.) Flora Monspeliaca, 1 vol. 8vo, Lugduni, 1765.

Haworth sax. enum. Haworth (Adrian Hardy.) Saxifragearum Enumeratio, or a new arrangement of all the known species and varieties of that intricate Tribe of Plants, 1 vol. 8vo. London, 1823.

Haworth supp. pl. succ. Id. Supplementum Plantarum Succulentarum, 1 vol. 12mo. Londini, 1819.

Hooker exot. flor. Hooker (W. Jackson.) Exotic Flora, 8vo. 1823 et seq.

Hornem. hafn. Hornemann (J. W.) Hortus regius botanicus Hafniensis, 8vo. Hafnia., 1813. Supplementum, 12mo. 1819.

Hort. berol. Hortus Berolinensis. Fasc. fol. Berolini, 1806 et seq.

Hort. cliff. Linnæus (Carolus.) Hortus Cliffortianus, 1 vol. fol. Amstelodami, 1737.

Hort. Kew. Hortus Kewensis. ed. 2 d. 5 vol. 8vo. London, 1810-1813.

Hort. sub. lond. Sweet (Robert.) Hortus Suburbanus Londinensis, or a Catalogue of Plants cultivated in the Neighbourhood of London, 1 vol. 8 vo. London, 1818.

Hort. trans. Transactions of the Horticultural Society of London, 4 to. London, 1812 et seq.

Jacq. aust. Von Jacquin (Nicol. Jos.) Floræ Austriaca Icones, 5 vol. fol. Vindobone, 17.73-1778.

Jacq. lort. vindob. Id. Hortus Botanicus Vindobonensis, 3 vol. fol. Vindobone, 1770-1776.

Jucq. icon. rar. Id. Icones Plantarum rariorum, 3 vol. fol. Vindobone, 1781 $-1793$.

Jacq. miscel. Id. Miscellanea austriaca ad botanicam etc. spectantia, 2 vol. 4 to. Vindobono, 1770-1781. 
Jacq. schoenb. Id. Plantarum rariorum horti cæsarei Schnenbrumensis, 4 vol. fol. Vienna, 1797-1804.

Juss. gen. Jussieu (Antoine Laurent.) Genera plantarım, 1 vol. 8vo. Paris, 1789.

Kunth Synops. Kunth (Carolo Sigism.) Synopsis Plantarum æquinoctialium Orbis novi, vol. 1-3, 8vo. Paris, 1822 $-1824$.

Lag. gen. et spec. Lagasca (Mariano.) Genera et species Plantarum qua aut novæ aut nondùm rectè cognoscuntur, 4to. Madriti, 1816.

S Lamarck encycl.

Lum. dict.

Monet de la Marck (Jean Bapt.) Encyclopédie méthodique Botanique, 4 to. Puris, 1823 et seq.

Lam. ill.gen. Id. Illustration des Genres, 4 to. Puris, 1791 et seq.

Link enum. Link (H. F.) Enumeratio Plantarum horti regii Botanici Berolinensis altera, vol. 2, 8vo. Berolini, 1821 -1822.

Linn. in act. upsal. Linrıæus (Carolus.) Acta litteraria et scientiarum Upsalia aut $\mathrm{ab}$ academia Upsaliensi publicata, 1720.

Lin. sp. Id. Species Plantarum, 8vo. Holmia, 1753 è seq.

Linn. trans. Transactions of the Linnean Society, 4to. London, 1791-1824.

Loddiges' Bot. Cab. Loddiges' (Conrad.) and Sons. Botanical Cabinet, 4to. et 12mo. London, 1817-1825.

Lour. cochinch. De Loureiro (Joannes.) Flora Cochinchinensis, 2 vol. 4 to. Ulyssipone, 1790, ed. II. cur. C. L.Willdenow, 2 vol. 8vo. Bernlini, 1793.

Marsh. Bieb. flor. taur. cauc. Marschall de Bieberstein (L. B. Fred.) Flora Taurico-Caucasica, 8vo. Charkovioe, 1808-1819.

Meerb.ic. Meerburg(Nicol.) Plantarum selectarum icones pictæ. fol. Lugd. But. 1798.

Mich.flor amer. Michaux (Andre.) Flora Boreali Americana, 2 vol. 8vo. Pari. siis, 1803.

Miller's Gard. dict. Miller (Philip.) The Gardener's Dictionary, fol. London, 1731-1768.

Mor. hist. Morison (Robert.) Historia Plantarum universalis Oxoniensis, 2 vol. fol. Oxonii, 1680.

Nuttal. gen. amer. Nuttall (Thomas.) The genera of North American Plants, and a catalogue of the species, 2 vol. 12mo. Philadelphia, 1818.

Pallus it. Pallas (Peter Simon.) Pallas Keise durch verschiedene provintzen des Russischen Reichs. 3 vol. 4to. Petersburg, 1771-1776.

Pers. syn. Persoon (Christ. Henr.) Synopsis Plantarum seu Enchiridium Botanicum, 2 vol. 12mo. Paris. I. 1805. II. 1807.

$P l$. rar. hung. Waldstein (Franc.) et Kitaibel (Paul.) Descriptiones et Icones plantarum rariorum Hungaria, 3 vol. fol. Vienne, 1802-1812.
Poir. dict. Poiret (J. L. M.) Encyclopédia métlodique, Dictionnaire de Botanique. Paris, 4to. 1804-1808.

Poir. supl. Id. Encyclopédie méthodique supplément au Dictionnaire de Botanique, 4to. Paris, 1810-1816.

Pursh fl. amer. Pursli (Frederick.) Flora America Septentrionalis, 2 vol. 8vo. London, 1814.

Ramat. in journ. d. hist. nat. Journal d'histoire naturelle, 2 vol. 4to. Paris, 1792.

Redoute liliac. Redoute (P. J.) Les Liliacées, 8 vol. fol. Paris, 1802-1816.

Retz. obs. Retzius (And. Joh.) Observationes Botanicæ, 6 fasc. fol. 1 ed. I. 4to. . Londini, 1774. Ed. II. Lipsia, $1779-1791$.

Rom. et Schult. syst. veg. Rœmer (J. J.) et Schultes (F. A.) Systema Vegetabilium, 8vo. Stutgardia, 1817-1820.

Roth neue Beytrage. Roth (Alb. Wilh.) Beitræge zur Botanik. 2 theil, 12mo. Bremen, 1782-3.

Salisb. parad. Salisbury (Rich. Antl.) The Paradisus Londinensis, the figures by W. Hooker, 2 vol. 4 to. London, $1805-1508$.

Salisb. prodr. Id. Prodromus stirpium in horto ad Chapel Allerton, 1 vol. 8vo. London, 1796.

Schkuhr handb. Schkuhr (Christ.) Botanisches handbuch. 3theil,8vo. 1791--1803.

Schrad. ver. Schrader (Henr. Adolph.) Commentatio de Veronicis spicatis, 8 vo. Gotting $\mathscr{e}, 1803$.

Schrank hort. monuc. Schranck (Franz von Paula.) Plantæ rariores horti Mo. nacensis. Munich, 1817-1819.

Sibth. $f$. groe. Sibthorp (John.) Flora Graca, ed. J. E. Smith, fasc. fol. London, 1806 et seq.

Smith exot. bot. Smith (James Edward.) ExoticBotany, 2vol. London, 1804--1808.

Smith in Rees's cycl. Rees (Abr.). The new Cyclopæedia. The Botanical articles by Sir J. E. Smith, 4to. London.

Sprengel pug. Sprengel (Kurt.) Plantarum minus cognitarum pugillus primus, 8vo. Hala, 1813.

Steudel nomen. Steudel (Ern.) Nomenclator Botanicus, vol. 1, 8vo. Stutt. gardtia et Tubinga. 1821.

Swt. hort. brit. Sweet (Robert.) Hortus Britannicus, 1 vol. Svo. London, inedit.

Tenor prod. fl. nap. Tenore (Michel.) Prodromus Flora Napolitana.

Thunb. jup. Thunberg (Car. Petr.) Flora Japonica, 1 vol. 8vo. Lipsia, 1784.

Vent. hort. cels. Ventenat (Etienne Pierre.) Description des plantes nouvelles ou peu connues du jardin de J. M. Cels. 1 vol. fol. Paris, 1800.

Waldst. et Kitaib.hung. Vid. Pl. rur.hung. Walt. $f$ car. Walter (Thomas.) Flora Caroliniana, 1 vol. 8vo. Londini, 1788.

Willd. enum. Willdenow (Car. Lud.) Enumeratio plautarum horti bot. Berolinensis, 2 vol. 8vo. Berolini, 1809. Suppl. 1813.

Willden. $s p$. pl. Id. Species Plantarum, vol. 5, 8vo. Berolini, 1797-1810. 



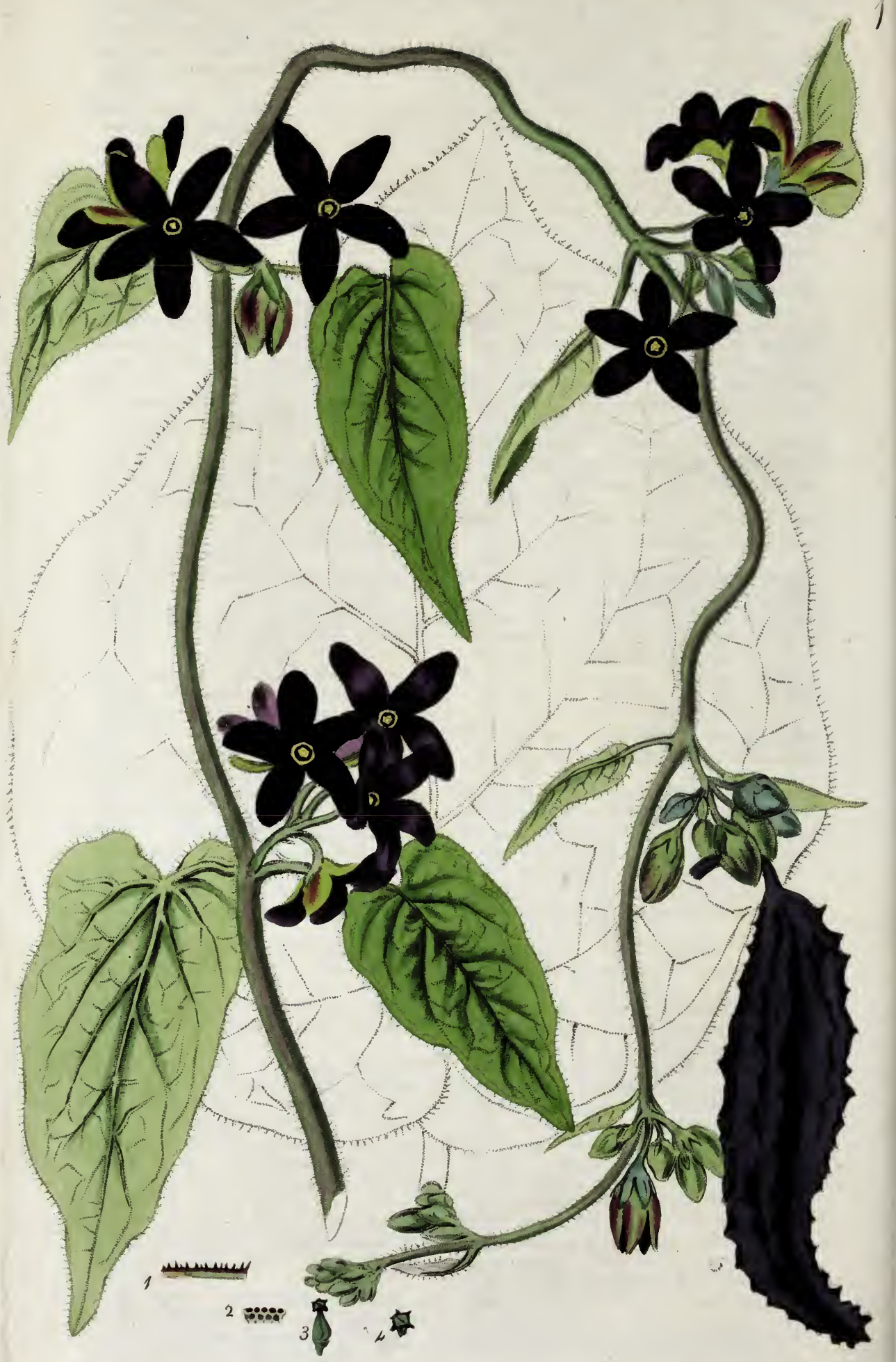

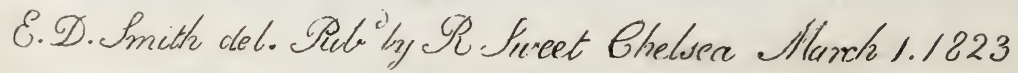




\title{
GONOLOBUS hirsutus.
}

\author{
Hairy Gonolobus.
}

Natural Order. AsclePiAdeA. Brown prodr. 458.

GONOLOBUS. Massa Pollinis læves, 10, transversæ. Corolla subrotata. Semina comosa. Brown Hort. Kew. ed. 2. v. 2. p. 82.

Herbæ v. Suffrutices volubiles. Folia opposita, cordata. Flores umbellati, axillares $v$. terminales.

G. hirsutus, sarmentis petiolisque hirsutissimis, foliis sensim acuminatis utrinque pubescentibus, corollæ laciniis oblongo-ovalibus obtusis, folliculis oblongis muricatis. Pursh fl. amer. sept. vol. 1. p.179.

Gonolobus hirsutus. Mich. flor. amer. 1. p. 119. Rom. et Schult. syst. veg. 6. 11. Hort. sub. lond. p. 51. Steudel nomen. $p .380$.

Vincetoxicum acanthocarpos. Walt. fl. car. 104.

Root perennial. Stems herbaceous, climbing, thickly clothed with a dense ferruginous pubescence, and longer hairs intermixed. Leaves opposite, cordate, hairy on both sides, reticulately veined; lower ones very large, 5 inches long and $4 \frac{1}{2}$ wide, roundly cordate, ending abruptly in an acute point, the sinus overlapping at the base: upper leaves narrowly cordate, gradually tapering to a sharp point, and open at the base, about 2 inches long, to scarcely 1 wide. Petioles hairy, on the lower leaves long, purple, and furrowed on the upper side; on the upper ones, about half an inch long, and nearly cylindrical. Umbels many-flowered. Peduncles 
lateral, not so long as the pedicles, densely pubescent, as is the pedicles and calyx and the outside of the corolla. Calyx 5-parted, segments short, lanceolate, acute. Corolla of 1 petal, rotate, deeply 5 -parted, of a lively brown purple colour ; segments oblongly-oval, obtuse, spreading; the inside smooth and glossy, the outside pubescent. Crown in the centre 10-toothed, with smaller teeth between them. Siamens 5. Pollen masses 10, smooth. Germens and Stigmas 2. Follicles oblong, hooked at the point, muricate.

For the opportunity of giving a figure of this rare and handsome plant, we are indebted to Mr. Knight, of the Exotic Nursery, King's Road, Little Chelsea, where our drawing was taken in September last, and the fruit was added in October, when it ripened. It is a native of North America, growing spontaneously, according to Pursh, from Pensylvania to Carolina. Mr. Knight has it cultivated on a little slope of peat earth, with some other scarce American plants : from its appearance, we suspect it will grow to the height of ten or twelve feet, if trained up a stick or trellis, where it will flower from June to October, if the weather prove favourable. Pursh mentions it as growing in hedges near rivulets; but we should think it not adviseable to plant it in a moist situation in this country, as its tuberous roots would be apt to suffer from too much wet. The present plants were in a flourishing state in a dry situation.

We have no doubt but it might be increased by dividing the roots, as well as by seeds.

1. The ten-toothed crown of the corolla spread open, showing the smaller teeth between the others. 2. The 5 stamens with the 10 masses of yellow pollen, one on each side of the anther. 3. The 2 germens with their stigmas. 4. Stigmas. 5. The full grown ripe follicle, all magnified, except the last. 



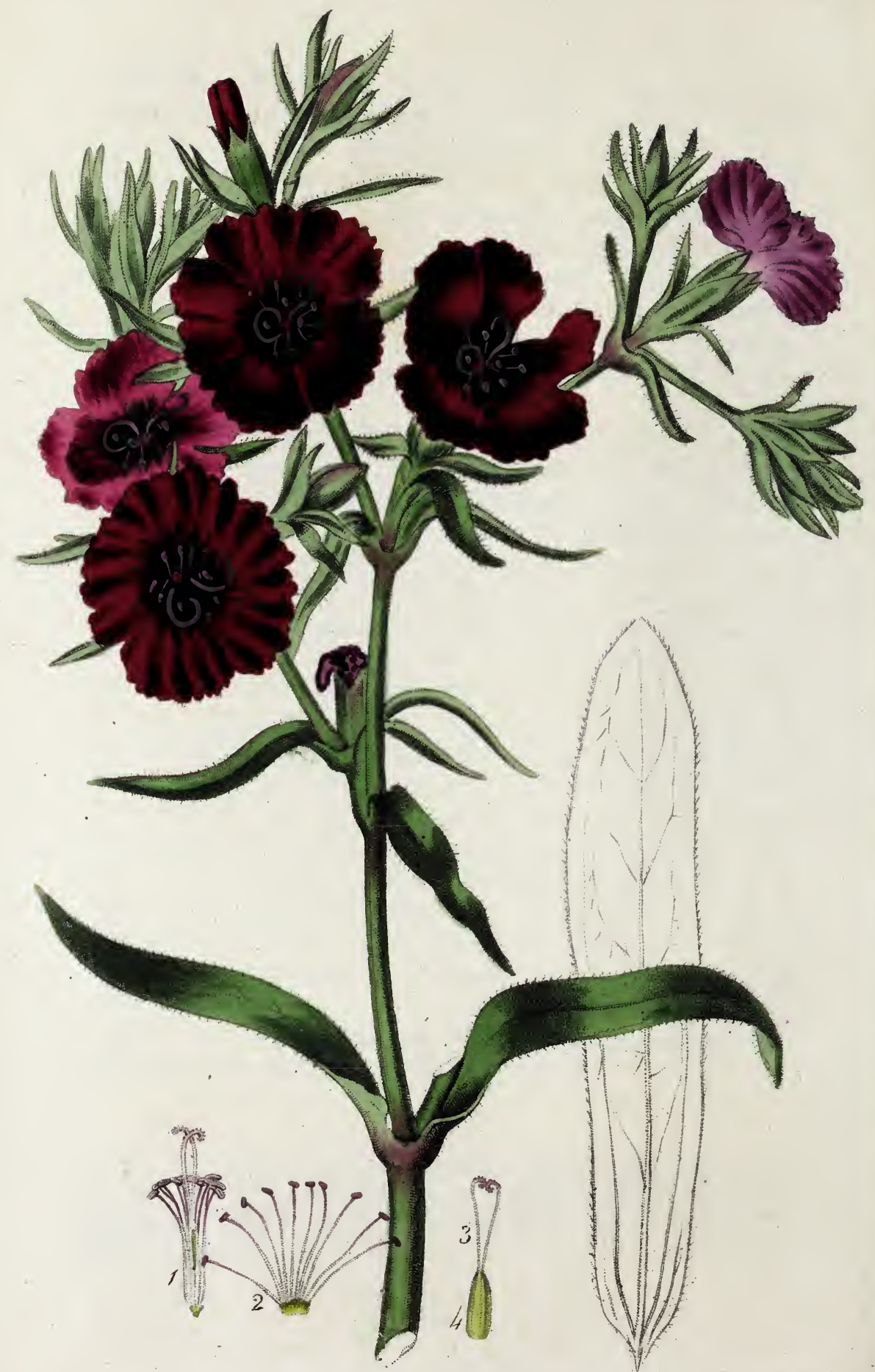

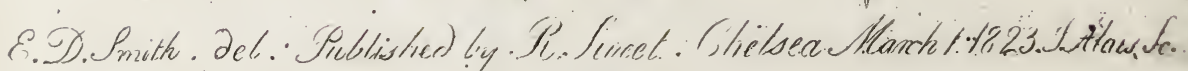




\title{
DIANTHUS latifolius.
}

\author{
Broad-leaved Pink.
}

Natural Order. Caryophylles. Juss. gen. 299.

DIANTHUS. Calyx cylindricus, longus coriaceus, 1-sepalus; basi squamis 4-8. Petala 5, unguiculata. Styli 2 , sæpe recurvi. Caps. cylindrica, 1-locularis, apice dehiscens.

D. latifolius, floribus aggregatis racemoso-corymbosis, squamis calycinis lanceolatis acutis demum calycem superantibus, petalis dentatis, foliis oblongo-lanceolatis trinerviis.

Dianthus latifolius, Willd. enum. v. 1. p.466. Jink enum. v. 1. p. 418. Hort. sub. lond. p. 99. Steud. nom. p. 271.

Root perennial. Plant herbaceous, short, tufted. Leaves sessile, oblong lanceolate, three-nerved, smooth, of a green opaque colour, margins rough; root leaves from 4 to 5 inches long, and $\frac{3}{4}$ of an inch wide, bluntish, or ending abruptly in an acute point; stem leaves opposite, shorter and acute. Flowerstem obsoletely 4 -sided, slightly channelled, smooth. Flowers loosely aggregate, racemosely-corymbose, sessile. Scales of the Calyx 4, leafy, widely lanceolate, taper-pointed, about the length of the calyx before the flowers expand, afterwards growing to nearly the length of the petals, margins membranaceous near the base. Calyx of 1 sepal, tubular, cylindrical, channelled with numerous furrows, 5-cleft; segments taper-pointed, longer than the ungues. Petals 5, unguiculate, with broad lamina, which are deeply crenate, of a bright dark red or purple, with a dark circle near the base. Filaments 
10, inserted in the receptacle. Anthers incumbent, 2-celled. Capsule smooth, cylindrical. Styles 2, smooth. Stigmas 2, red and feathered.

This plant, as Mr. Milne noticed to us, is as near as possible intermediate between D. barbatus and D. chinensis. It differs from the former, in its flowers not being fascicled and double the size, in the scales of the calyx being broader, and in its more compact and shorter growth; from the latter, it differs altogether in habit, but its flowers are very similar; it is a very ornamental herbaceous perennial, and continues to flower the greater part of the sum mer, and till late in autumn; it scarcely attains to a foot in height, oftener being only 6 or 8 inches; but that depends chiefly on the situation where it grows. It delights in a light rich garden soil, in a dryish situation, as it would be apt to rot if the ground was too moist; it is also a very proper plant for ornamenting rock work, in which it would appear to great advantage. It may be increased by cuttings planted under a hand-glass in the open ground, in a shady situation; but they must be planted thinly, or they will damp off; when rooted, they must be hardened to the air by degrees, and may then be planted where they are to remain.

Our drawing was taken at the Nursery of Messrs. Whitley, Brames, and Milne, of Fulham, in September last.

1. Stamens and pistils divested of the corolla and calyx. 2. The 10 stamens spread open, all joined at the base. 3. The 2 styles terminated with 2 simple incurved stigmas. 4. Germen, all natural size. 



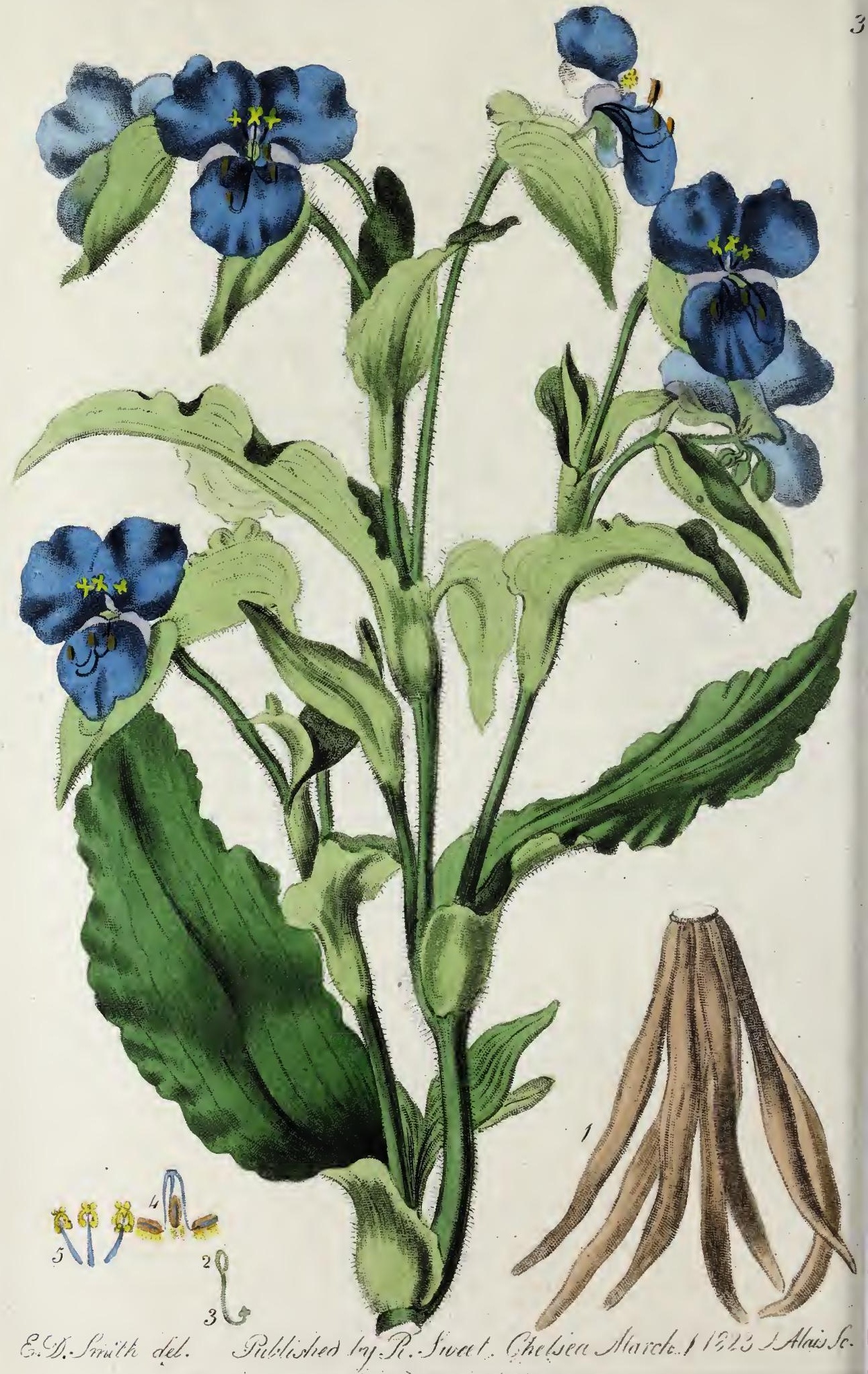




\title{
COMMELINA colestis.
}

\author{
Sky-blue Commelina.
}

Natural Order. Commelinez. Brown prodr. 268.

COMMELINA. Perianthium sexpartitum, inæquale; foliola 3 exteriora extus calycina, persistentia: interiora petaloidea, unguiculata, decidua, tertia quandoque dissimili v. abortiente. Stamina sex (v. 5.) Antherarum 3, (nunc 2-4) dissimiles : vix polliniferæ. Involucrum monophyllum, conduplicatum v. cucullatum, persistens, capsulas includens.

Herbæ sape diffusa. Folia vagina integra. Pedunculus apice fasciculatim multiflorus, floribus hermaphroditis : altero exteriore unifloro masculo scepius stipatus. Brown prodr. 269.

C. coelestis, corollis æqualibus, involucris cordatis acuminatis conduplicatis, racemis multifloris, pedunculis pubescentibus, pedicellis glabris, foliis oblongo-lanceolatis sessilibus glabris : margine undulatis, vaginis ciliatis, caule erecto.

Commelina colestis. Willd.enum, v. 1.p. 69. Link enum. v. 1. p. 61. Hort. sub. lond. p. 12. Rum. et Schult. syst.1. p. 538. Steud. nom. p. 214.

Commelina tuberosa. Bot. mag. 1695.

Root perennial, composed of a fascicle of long subcylindrical tubers. Stems several from the same root, erect, smooth, slightly furrowed, not much branched. Leaves sessile, sheathing the stem, oblongly lanceolate, taper-pointed, undulate, smooth but fringed at the base, 7-nerved. Sheaths fringed. Peduncles terminal and axillary, densely pubescent, scarcely as long as the leaf. Involucre cordate, taper-pointed, pubescent, doubled inwards so as to cover the flowers before they expand. Raceme many-flowered, inclosed in the involucre. Pedicles smooth, bent forward before the flower expands, erect when expanded, afterwards bent backwards. 
Flower 8-parted, of a beautiful sky-blue, 3 outer segments calyx-like, persistent; 3 inner ones petallike, unguiculate, deciduous. Stamens 6. Anthers 3 perfect, and 3 barren; fertile ones incumbent, oblong, 2-celled; sterile ones of a different shape, divided into 4 parts, yellow. Style smooth, longer than the stamens. Stigma slightly 3 -lobed.

This ornamental plant has been sometimes confused with C. tuberosa, from which it differs in several respects; this having smooth leaves and hairy peduncles, whereas C. tuberosa has hairy leaves and smooth peduncles; we are not certain whether C. tuberosa will prove to be so hardy as our present plant; we hope to ascertain that the present season. Plants raised from seeds early in spring, if brought forward with a little artificial heat, and then planted in the open ground, will flower in autumn; as soon as their tops begin to die away, the roots must be taken up, and kept in a little dry earth or sand, out of the reach of frost, till the following spring, in the same manner as Dahlias, or other tuberous roots. The latter part of April, or the beginning of May, according as the season suits, they must be planted in the ground; or they might be brought forward earlier in a hot-house, or green-house, or hot-bed frame, and from thence be planted into the flower borders, where they will continue to bloom for a considerable time, and ripen their seeds; the comınon garden soil will suit them very well, the lighter and more sandy the better.

Our drawing was taken in September last, at the Nursery of Mr. Colvill, King's Road, Chelsea.

1. The fascicle of tuberous roots, natural size. 2. Germen. 3. Style and 3-lobed stigma. 4. Three fertile stamens. 5. Three barren ditto, divided into 4 lobes, all slightly magnified. 



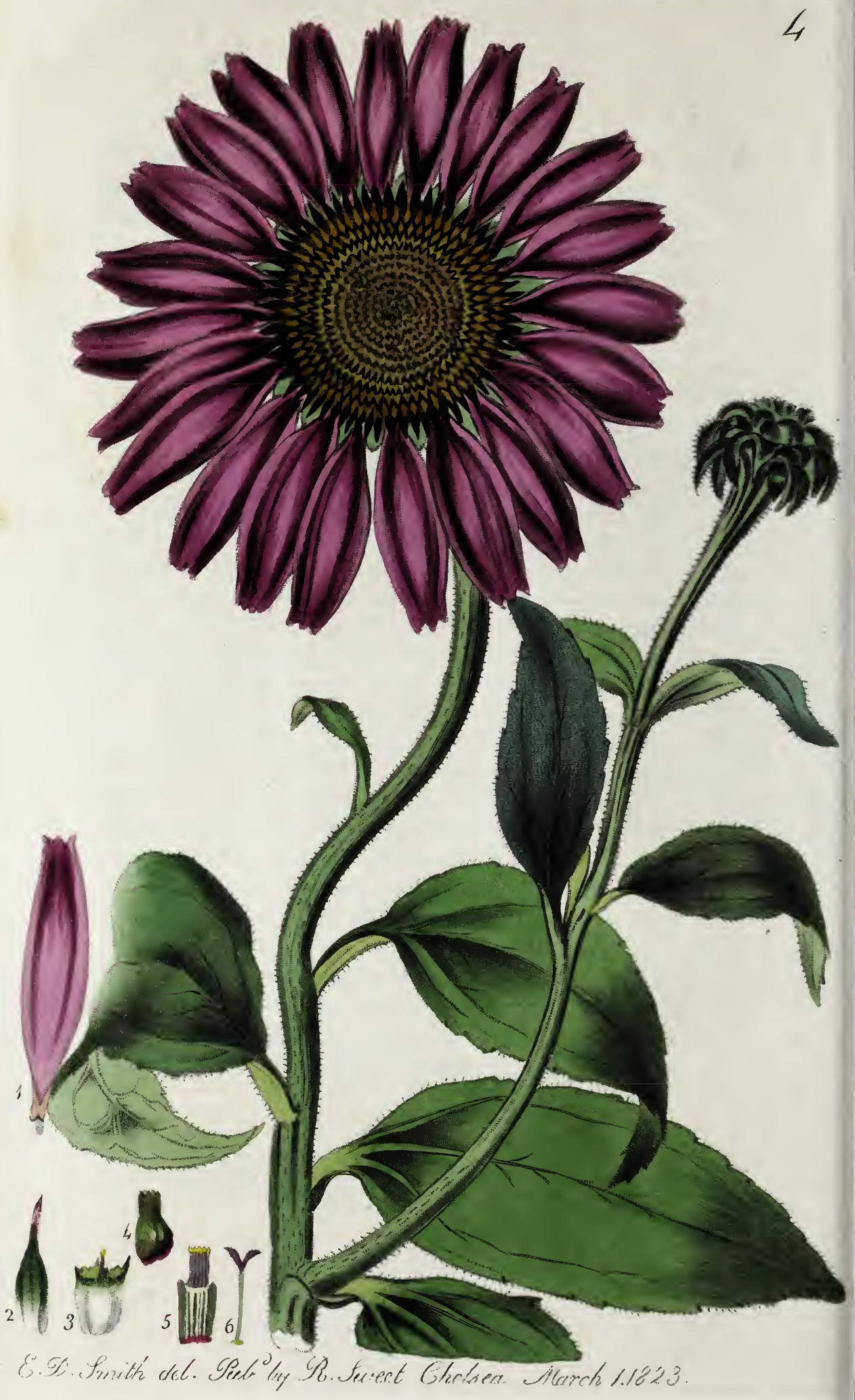




\section{RUDBECKIA serotina.}

\section{Late-flowering hispid-stalked Rudbeckia.}

Natural Order. Composite. Adanson fam. 2.103.

RUDBECKIA. Flores radiati, ligulis neutris. (Involucrum) duplici serie polyphyllum subæqualis patens. Semina apice marginata, margine membranaceo 4-dentato. Receptaculum (paleaceum,) conicum.

Herbæ alternifolia, quaedam asperce; Flores sape terminales; discus interdum subfuscus; ligulæ quarumdam luteo-crocece, in $\mathbf{R}$. purpurea (et serotina) purpurascentes. Juss. gen. 189.

R. serotinc, caule hispido, foliis inferioribus lato-ovatis basi attenuatis remote dentatis asperrimis : caulinis lanceolatoovatis utrinque acuminatis subintegerrimis, radiis patentibus apice tridentatis.

Rudbeckia purpurea, $\beta$ serotina. Nuttal.

Rudbeckia speciosa. Hortulanorum. Link enum. v. 2. p. 353.

Root perennial. Stems several from the same root, from 2 to 5 feet high, branching, thickly clothed with short stiff hairs. Leaves very rough; root ones very large, widely ovate, tapering at both ends, distantly and unequally toothed, from 3 to 5 -nerved: stem leaves much narrower, lanceolately ovate, entire or scarcely toothed. Petioles on the root leaves very long, sheathing at the base, deeply channelled on the upper side, and bluntly keeled on the lower. Peduncles longer than the leaves, furrowed, much swollen near the flower, thickly clothed with short stiff hairs. Involucre many-leaved; scales lanceolate, acute, concave, ciliate, reflexed, in three tiers one above the other, the lower ones generally the longest. Receptacle conical, chaffy. Chaff longer than the florets of the disk, very rigid, the lower part keeled and green, the point cartilaginous, bluntish, of a brownish horn colour. Rays barren, broadly ligulate, narrow at the base, point 3-toothed, strongly 
nerved underneath, and furrowed on the upper side, of a light purple colour; in the floret is the rudiment of two hair-like stigmas. Florets of the disk tubular, 5-toothed, much shorter than the chaff. Stamens 5, filaments distinct. Anthers joined into a tube, exserted above the floret, scarcely the height of the chaff. Pollen bright yellow. Style green, smooth. Stigmas 2, purple, reflexed, feathered at the point. Seeds angular, crowned with a 4-toothed pappus, and between the 4 teeth are several other smaller ones.

This stately herbaceous perenuial is a native of North America, and has been introduced to our gardens about six or seven years since, where it has generally passed under the name of $\boldsymbol{R}$. speciosa; by which title we also find it recorded in Professor Link's Enumeratio, but without a description, as it is said not to have flowered in their garden; we have no doubt but it is the R. purpurea $\beta$ serotina of Nuttal, though he describes the rays as bifid, which in ours is 3-toothed. Mœnch has separated $\boldsymbol{R}$. purpurea from the other species, under the generic name of Echinacea; should it be hereafter confirmed as a distinct genus, our plant will rank with it as a second species: their rigid chaff and habit altogether is certainly very different from the others.

The present plant, in strong soil, will sometimes attain the height of 5 feet; in poorer soil, it will be considerably less. It begins flowering in July, and will continue in bloom, if the season be mild, till the middle of November. It will thrive well in any common garden soil, and increases freely by seeds, or dividing the roots.

Our drawing was taken at the Nursery of Mr. Colvill, in September last.

1. Barren floret of the ray, natural size. 2. Scale of the chaff. 3. Seed with its toothed pappus. 4. Floret of the disk. 5. The same cut open, to show its 5 distinct filaments and connected anthers. 6. Style and 2 stigmas, all magnified. 



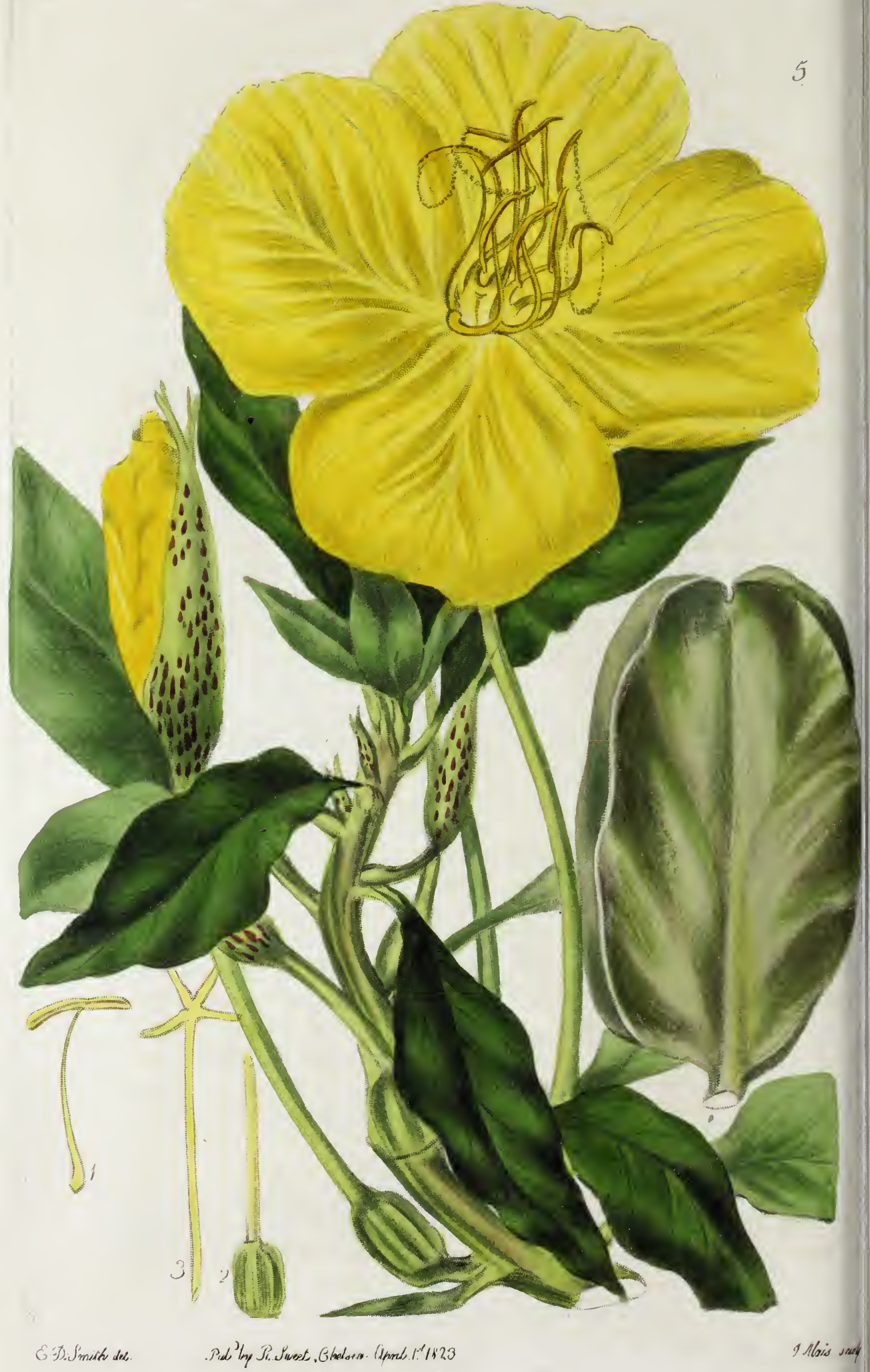




\section{OENOTHERA macrocarpa.}

\section{Large-capsuled OEnothera.}

Natural Order. Onagrarie. Jussieu.

CENOTHERA. Calyx 4-fidus, tubulosus. Corolla 5-petala; petalis integris. Stamina 8; filamentia omnia fertilia. Stigm. 4-fidum. Caps. 4-locularis, 4-valvis, infera. Sem. nuda, receptaculo centrali, 4-gono affixa.

C. macrocarpa, caule diffuso ramoso, foliis petiolatis elliptico-lanceolatis acutis mucronatis glanduloso-denticulatis integerrimisve margine nervisque sericeo-albidis, petalis obcordatis venosis, capsulis quadrialatis subsessilibus.

Enothera macrocarpa. Pursh Flor. Amer. Sept. supp. p. 734. excl. syn. Bot. may.

Root perennial. Stem of a woody texture at the base, branching. Branches spreading, covered with a short silky pubescence, furrowed, thickly clothed with leaves. Leaves petioled, elliptically lanceolate, acute, mucronate, entire, or sometimes distantly toothed with small glandular teeth ; margins thicker, of a horny substance, and with the nerves clothed with a whitish silky down. Petioles downy, about three times shorter than the blade of the leaf, convex on the upper part, and rounded on the lower. Capsule below the calyx, thickly clothed with white silky hairs, 4-winged; wings growing to a great size before the capsules ripen. Calyx tubular, tube in our specimen four inches long, of a greenish white; limb spathaceous, irregularly spotted with pale purple, sericeous, split on one side for the expansion of the petals, and divided into 4 segments at the base, which are joined above the middle and end in 4 subulate points. Petals 4 , the largest in 
the genus, inserted in the calyx, obcordate, but ending in a point, many-nerved, margins slightly toothed, of a light yellow colour. Stamens 8, also inserted in the calyx. Filaments dilated at the base, and narrowed upwards, about half as long again as the anthers. Anthers linear, 2 celled, bursting in front to discharge the pollen, which is pale yellow. Style smooth, gradually thickening upwards. Stigma 4-cleft, segments cylindrical, blunt, spreading.

The present ornamental plant produces the largest flowers of any species belonging to the genus; it has been confused with $\mathbf{E}$. missourensis of the Botanical Magazine, pl. 1592, both by Pursh and Nuttall. Plants of both species are now growing in the Nursery of Mr. Colvill, by the side of each other, where they have been cultivated for several years, without varying in the slightest degree; they both produce perfect seeds, and the young plants raised from them always continue true to their species. The difference in the two when seen growing together, is very striking; the leaves of $\mathrm{EE}$. macrocarpa being elliptical, or elliptically lanceolate, tapering at both ends; of $\mathbf{E}$. missourensis linearly lanceolate, the stems and branches of the latter are longer and slenderer, and the flowers much smaller; but they are both very ornamental plants; the E. alata of Nuttall, belongs to the latter species, judging from his description.

This plant thrives well in a rich light soil, and will grow to the height of a foot, or 18 inches, if supported by a stick; but its more natural manner of growth is to trail on the ground; it is very well suited for ornamenting rock-work, but requires room for its branches to spread; it may be readily increased by seeds; or young cuttings, planted thinly under a hand-glass, will soon strike root.

1. Stamen. 2. Germen, and the lower part of the style. 3. Upper part of the style and 4-cleft stigma, all natural size. 
- 


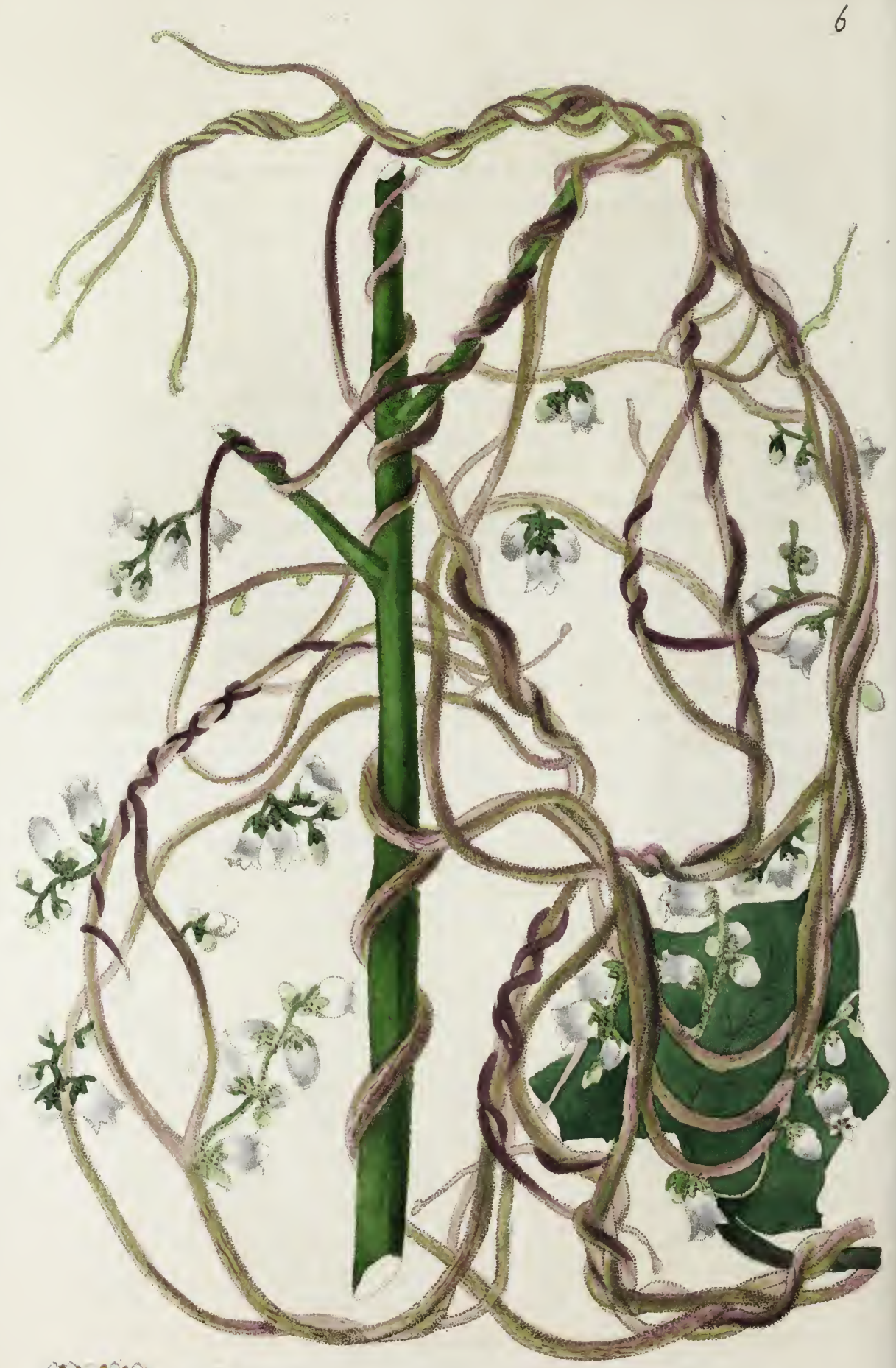

\section{2 correstas}

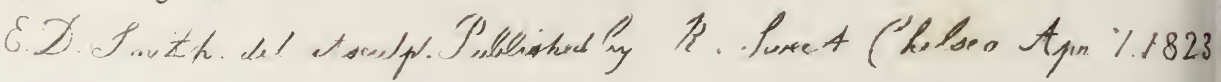




\title{
CUSCU'TA verrucosa.
}

\author{
Warted-calyxed Nepaul Cuscuta.
}

Natural Order. Convolvulaces. Brown prodr. 481. Sect. III. Embryo acotyledoneus.

CUSCUTA. Calyx 5-raro 4-fidus. Corolla globosourceolata, limbo 5-fido, marcescens. Ovarium 2-loculare, loculis dispermis. Capsula bilocularis, circumscissa.

Herbæ aplyylla, volubiles, parasitica. Flores aggregati, subcapitati v. spicati, unibracteati. Squamæ 5, epipetala, infra filamenta, iisdemque opposita, raro deficientes. Brown prodr. 491.

C. verrucosa, digyna, stigmatibus lanceolatis obtusis basi dilatatis carnosis, squamis epipetalis fimbriato-laceris, antheris subsessilibus, calycis 5-fidi laciniis rotundatis verrucosis.

Parasitical on various plants. Stems succulent, twining, much branched. Branches smooth and glossy, of a brownish green colour, or sometimes purple, irregularly marked with purple linear spots, extending to a great distance, and laying hold of every branch within their reach. Racemes numerous, often 3 -flowered, but sometimes 9 or 10 -flowered. Flowers white with short succulent pedicles, very fragrant. Bractea 1, sessile, ovate, obtuse, concave, sheathing the pedicle. Calyx 5-cleft, segments roundish, succulent, persistent, thickly covered with small purple warts. Corolla urceolate, border 5-cleft, divisions blunt, reflexed; scales 5 , inserted into the base of the corolla, much fringed or lacerated. Anthers 5, nearly sessile, inserted into the tube just below the divisions of the border, and extending a c 2 
little above the mouth. Stigmas 2, nearly sessile, lanceolate, obtuse, widened at the base, succulent. Germen warted.

This curious parasitical plant was raised last Spring, at the Nursery of Mr. Colvill, from seeds sent him by Mr. George Potter, from the Botanic Garden at Calcutta, where they had been received from Nepaul; soon after the plants came up, they died off at the bottom, the tops catching hold of the nearest plant within their reach, and soon growing and spreading themselves in all directions, twining round all the young shoots and footstalks of the leaves, where they thrust out a kind of teeth, by which they inserted themselves into the plant. The more juicy and succulent the plant is, the stronger they grow; the strong growing species of Pelargonium suits them admirably.

The plants raised in Spring began flowering in September, and soon became entirely covered with flowers of a most delightful fiagrance, somewhat resembling a mixture of violets and cowslips ; and a plant that had taken hold of the ivy by Mr. Colvill's shop, soon covered a great part of it, where it continued in flower till the very severe frost, and ripened its seed. Mild Winters it would survive very well, as it stood several severe frosts without being injured. It might be treated as an hardy annual, or may be kept alive through the Winter, in a frame or greenhouse.

1. Calyx. 2. Corolla spread open, showing the 5 stamens, and 5 fringed seales. 3. One of the scales separated from the corolla. 4. Germen, terminated by 2 fleshy stigmas. 



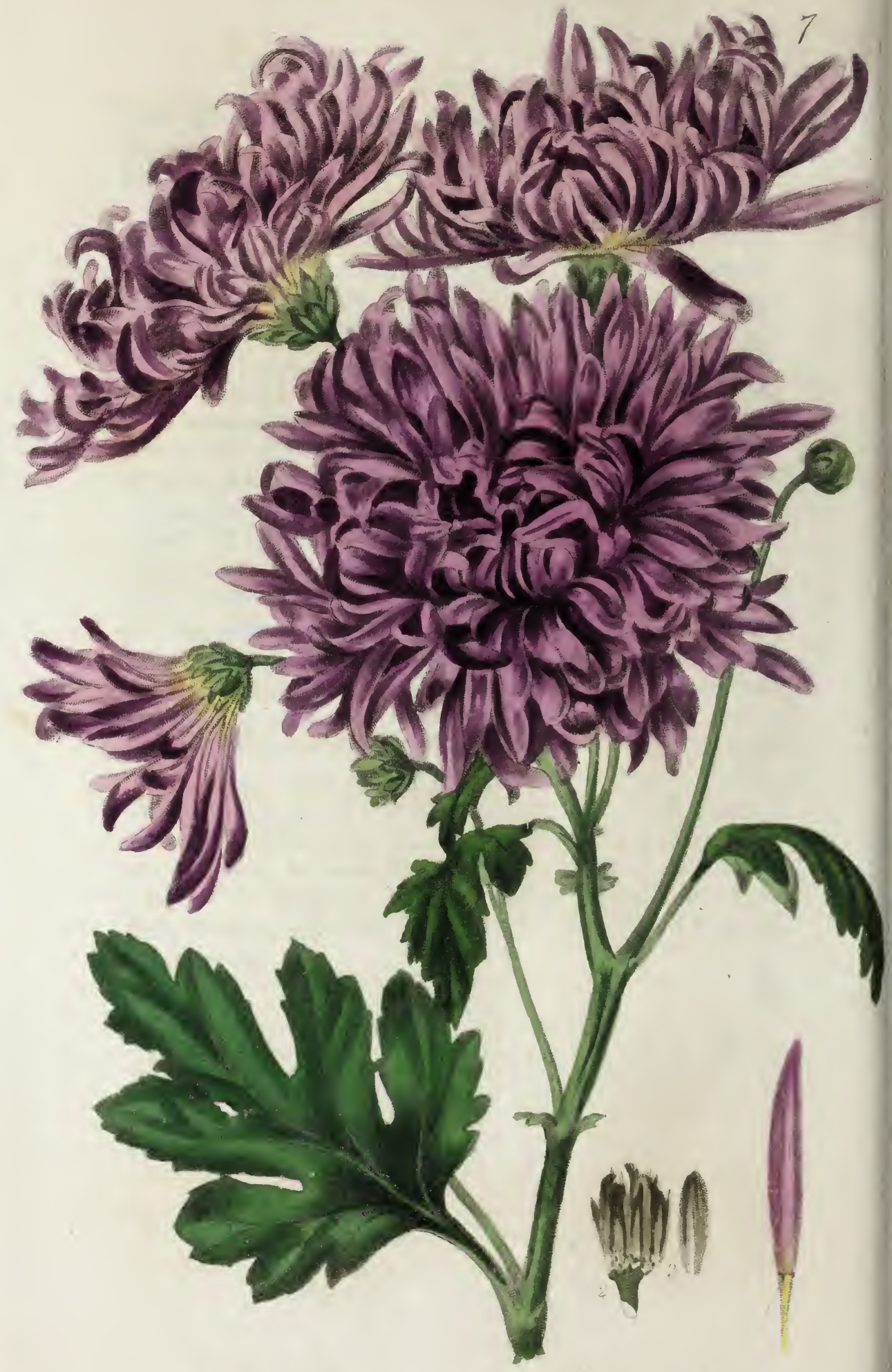




\section{CHRYSANTHEMUM sinense, var. involutum.}

Curled Lilac Chinese Chrysanthemum.

Natural Order. Composita. Adanson fam. 2. 103. CHRYSANTHEMUM. Flores radiati. Involucrum hemisphæricum, imbricatum; squamis marginalibus membranaceis. Recept. nudum. Pappus nullus s. marginatus.

(Suffrutices aut herbæ;) caulis simplex aut ramosus; folia simplicia, (lobata) aut pinnata; flores terminales, solitarii aut corymbosi. Juss. gen. 183.

C. sinense, foliis petiolatis sinuato-lobatis dentatis mucronatis subtus incanis stipulatis, receptaculo conico-convexo paleaceo v. nudo.

Chrysanthemum sinense. Sabine Mss.

Chrysanthemum purpureum. Pers. syn. 2. p.461. Steud. nom.p. 193.

Chrysanthemum indicum. Curtis magaz. 327. Hort. Kew. ed. 2. v. 5. p. 95. non Linn.

Anthemis grandiflora. Ramat. in jour. d. hist. nat. 2. p. 234. Desfont. arb. 1. p. 315.

Anthemis artemisiæfolia. Willden. sp. pl. 3. p. 2184. Enum. 911. Hort. sub. lond. 192. Link. enum. 2. p. 346.

involutum, floribus corymbosis confertis magnis lilacinis; medio pallidioribus, radiis apice involutis, receptaculum globosum paleaceum.

Root perennial, tufted. Stems numerous, woody at the base, from 2 to 4 feet high, more or less branched, obtusely angular, thickly clothed with a dense white tomentum. Branches spreading, and terminated with a compact corymbus of flowers. Leaves flat, sinuately 5-lobed, densely tomentose, particularly on the under side, much dotted; lower ones about 4 inches long, to $2 \frac{1}{2}$ broad, deeply lobed, and unequally toothed; lobes and teeth rounded, 
very obtuse; upper leaves much smaller, and pointed; lobes and teeth sharply acute. Petioles slightly winged, shorter than the leaf, deeply channelled on the upper side, and bluntly keeled on the lower; densely tomentose. Stipules of various forms, generally 2 or 3 -forked; segments lanceolate, on the large leaves obtuse; on the smaller ones acute, sometimes toothed. Peduncles tomentose, gradually increasing in size upwards; the lower ones longest. Involucre hemisphærical, composed of numerous scales over-lapping each other. Scales lanceolate, with brown membranaceous margins. Receptacle globular, chaffy, particularly on the upper part. Chaff spatulate, membranaceous, of a light brown colour, and curved inwards like the rays. Flowers full, composed wholly of rays, without florets in the centre. Rays open, not tubular, twisted or curled, the points curved inwards; outer ones of a dark lilac, inner ones much paler. Stamens none. Style slender, even with the tube of the ray. Stigmas 2 , recurved.

One of the beautiful new varieties of Chinese Chrysanthemum, lately introduced into the Garden of the Horticultural Society, from whence it is now distributed into many other collections. We believe the Society's collection now contains nearly thirty different varieties, many of which are very handsome; we have drawings of several, which will be published in our future numbers.

The introduction of so many beautiful varieties of the Chinese Chrysanthemums is a great acquisition to our gardens, particularly as they begin flowering in Autumn, after most other flowers are overblown; they will grow freely in any common garden soil, but should be planted in a south border, to have them flower well; they may be increased by dividing at the root, or by cuttings planted under hand-glasses.

1. Floret of the ray. 2. Chaffy receptacle divested of the calyx. 3. Scale of the chaff flattened out. 


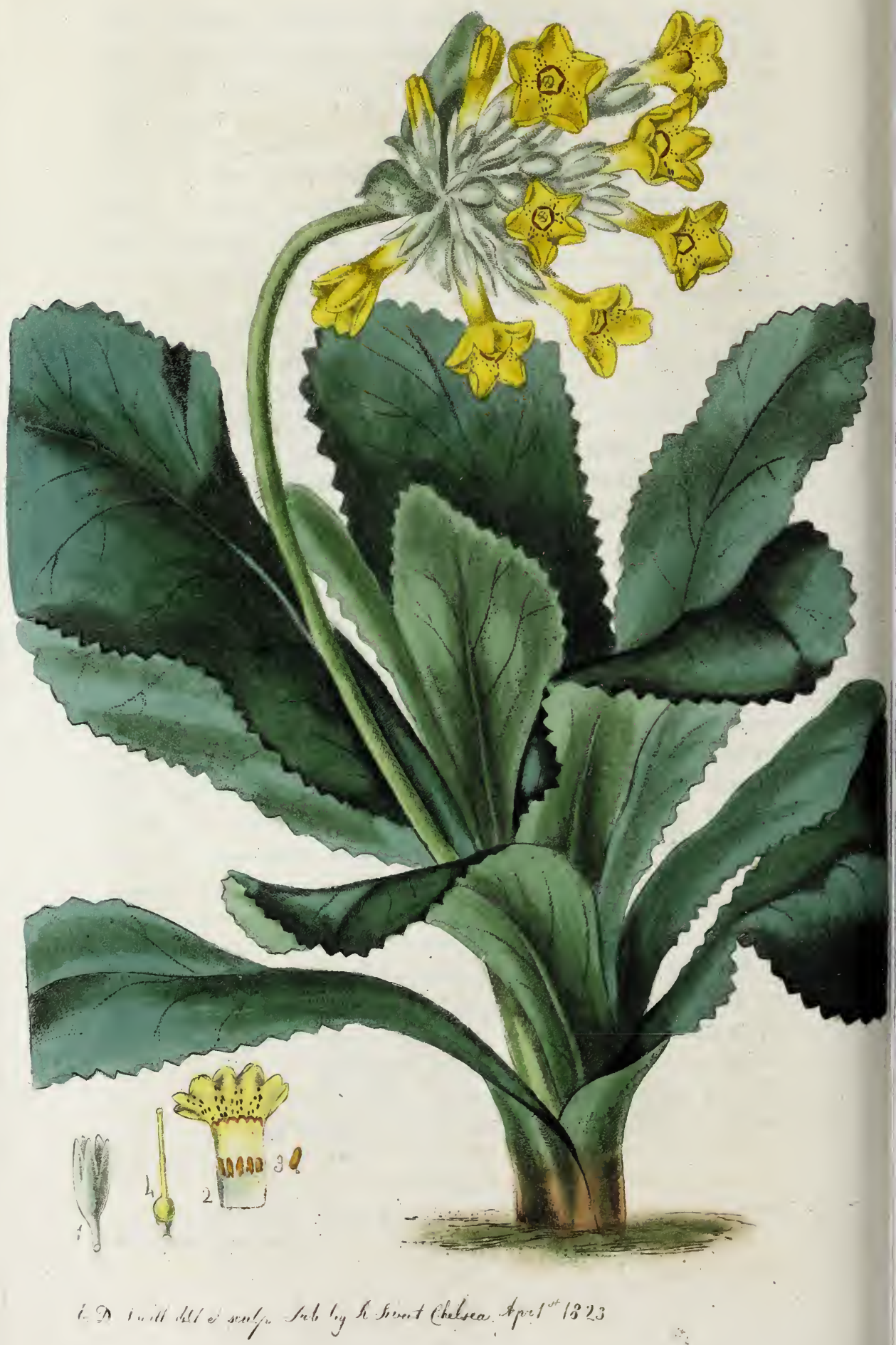




\title{
PRIMULA Palinuri.
}

\author{
Unequal-bracted Primrose.
}

Natural Order. Primulaces. Brown prodr. 427.

PRIMULA. Calyx tubulosus 5-dentatus persistens. Corolla tubus cylindricus; ore patulo; limbo emarginato. Stamina 5. Stigma 1, globosum. Capsula 1-locularis; ore 10-fido.

P. Palinuri, foliis obovatis crenatis glabris, scapo foliis altiore laterali, umbella nutante, involucro inæquali pedunculos subæquante, corollæ limbo margine incurvo.

Primula Palinuri. Willd. enum. v. 1. p. 191. Link enum. v. 1. p. 158. Hort. sub. lond. p. 32. Rom. et Schult. syst. 4. p. 138.

Subcaulescent. Stem short and stiff, erect. Leaves sessile, obovate, slightly undulate, deeply crenate, with rounded points, and attenuate at the base, of a greasy appearance and very soft, but scarcely viscous, about 2 inches broad, and $4 \frac{1}{2}$ long; when rubbed, emitting a powerful fragrance resembling Chamomile or Wormwood. Scape higher than the leaves, viscid, pubescent. Umbel many-flowered, nodding. Involucre of several unequal leafy bractes, some longer, others about the length of the peduncles. Bractes obovate, undulate, entire. Peduncles cylindrical, a little longer than the calyx, thickly covered with a white powder. Calyx 5-toothed, densely clothed inside and out with a white mealy powder. Corolla tubular, tube nearly twice the length of the calyx; limb scarcely half the length of the tube, emarginate; sides folded inwards, of a bright yellow colour, slightly farinaceous, with a golden circle at the mouth. Stamens 5, oblong, 
sessile, inserted about half way up the tube of the corolla. Germen globular, farinaceous. Style smooth, even with the mouth of the corolla, but lengthening after the flower is over-blown. Stigma capitate, point slightly depressed.

The plant from which our drawing was taken, was received last Summer, by Mr. Colvill, from the Botanic Garden at Berlin; soon after its arrival, it flowered; but not so strong as it did the second time, which was the latter end of December, when our drawing was made. It had been protected under a frame, to preserve the flower; but the plant itself is quite hardy. It is nearly related to P. $\boldsymbol{A u}$ ricula, but is a much stronger growing upright plant; the flowers are much smaller, not unlike the Cowslip, which it also resembles in fragrance. It may be cultivated successfully, by planting it in a dry border in a light loamy soil; or it may be grown in a pot, in a mixture of sandy loam and peat; and is readily increased by seeds, or by suckers from the root.

1. Calyx. 2. Corolla spread open, showing the insertion of the stamens. 3. Stamen. 4. Germen, Style, and Stigma, natural size. 


\section{.}




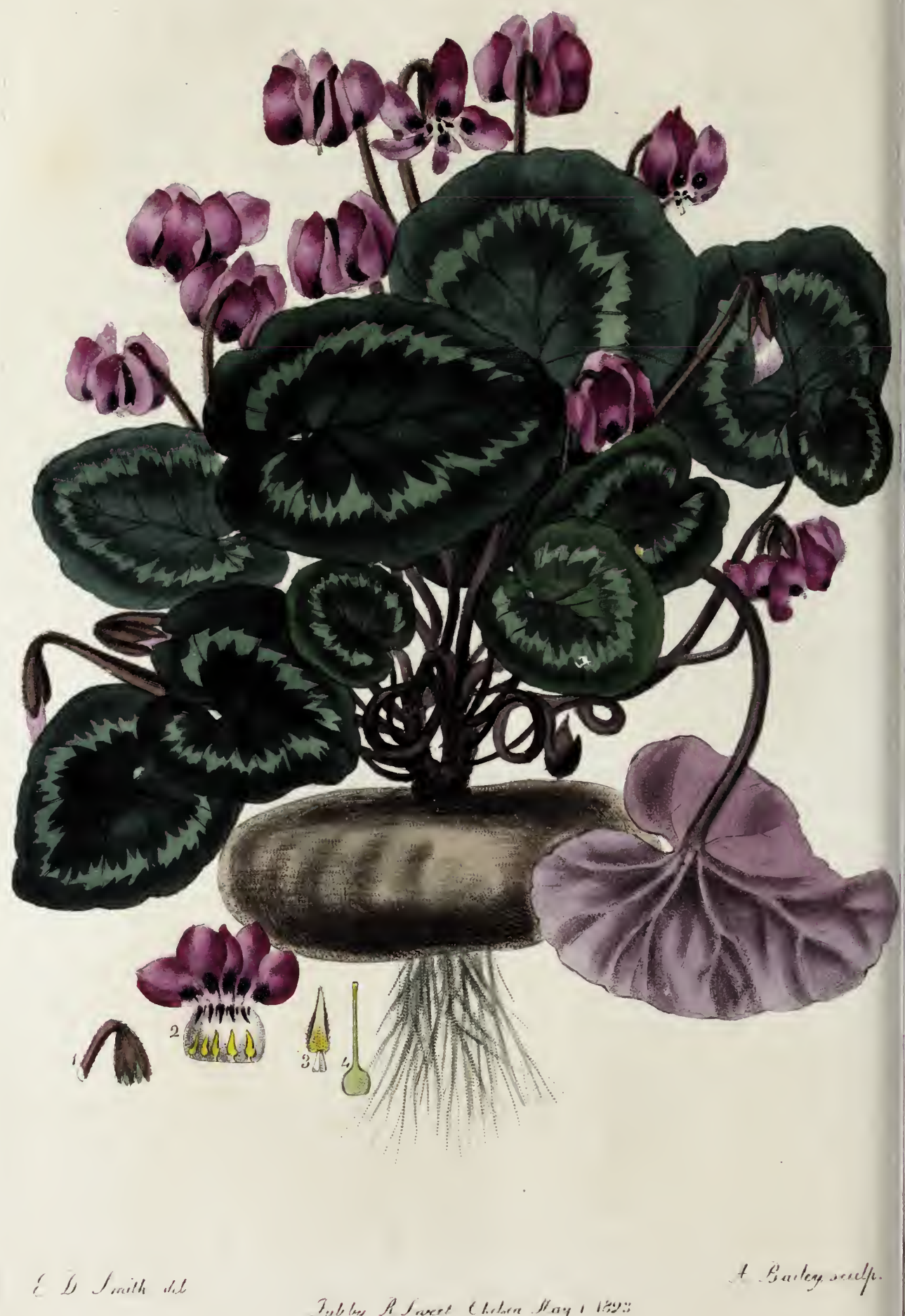

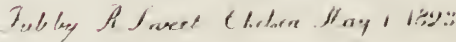




\section{CYCLAMEN vernum.}

Vernal Cyclamen.

Natural Order. Primulaces. Brown prodr. 427.

CYCLAMEN. Calyx 5-fidus. Corolla rotata, reflexa, tubo brevissimo: fauce prominente. Stamina 5; antheræ conniventes. Stigma 1. Bacca tecta capsula. Scapi 1-flori; flores nutantes.

C. vernum. subcaulescens, foliis cordatis subcrenulatis apice emarginatis ; sinu subclauso, corollæ laciniis oblongo-ovatis, stylo exserto.

Cyclamen vernum minus orbiculato folio inferne rubente, flore minore ruberrimo. Mor. hist. Lesser spring Sowbread with roundish leaves of a reddish colour underneath, with small deep red flowers. Miller's Gard. dict. ed. 3. Cyclamen No. 4.

Cyclamen vernale. Steud. nomen. p. 247.

Cyclamen Coum. Loddiges' Bot. cab. no. 108. nec aliorum.

$\boldsymbol{R o o t}$ tuberous, round and flat, not unlike a Turnep; of a reddish brown colour. Stems short, rough, branched, and clothed with numerous leaves and flowers. Leaves cordate, concave, slightly crenulate, emarginate, upper side green, marked with an unequal circle of white, underneath of a reddish purple; sinus overlapping at the base. Petioles longer than the leaves, nearly cylindrical, crooked, very slender near the base. Peduncles reaching a little above the leaves, gradually tapering upwards, 1-flowered. Flowers nodding, of a rosy red colour, darker near the month, where there is a white circle, inside striped with red. Calyx 5-cleft, pubescent ; segments lanceolate, acute, slightly keeled. Corolla rotate, reflexed; segments ovate, or 
oblong; margins curved inwards. Stamens 5, inserted into the base of the tube. Filaments short and flat, dilated at the base. Anthers attached to the filaments at the base, 2-celled, sharp-pointed, fringed, included in the tube. Germen globular, smooth. Style smooth, tapering upwards, exserted a little above the mouth. Stigma small, flat.

The present beautiful little plant seems to have been almost entirely overlooked by Botanists, since the time of Miller. In Martyn's edition of Miller's Dictionary, it is recorded as a variety of C. persicum; to which it certainly is scarcely at all allied, except in the form of the leaves, and the white circle on their upper side. The flowers are nearly the same as in C. Coum.; but the style is exserted a little beyond the mouth; the plant is altogether more robust, and the leaves and flowers are produced on a kind of short flat stem that branches from the tuber, not directly from the crown of the tuber, as in C. persicum, and C. Coum. The leaves are also cordate, and the sinus frequently overlapping at the base; in C.Coum. they are reniform, and have a large opening at their base, and are entirely green on their upper surface.

It will succeed well in a warm border, in a light sandy soil ; or it may be grown with advantage in small pots, in an equal mixture of loam, peat, and sand; it can then be protected under a frame in Winter, during which time it requires very little water. The only method of propagating it, is from seeds, which ripen plentifully, if care be taken to scatter some pollen on the stigma when in full bloom.

Drawn at the Nursery of Mr. Colvill, the beginning of March last.

1. Calyx. 2. Corolla spread open, showing the insertion of the Stamens, natural size. 3. One of the Anthers magnified, burst on each side. 4. Germen, Style, and Stigma magnified. 


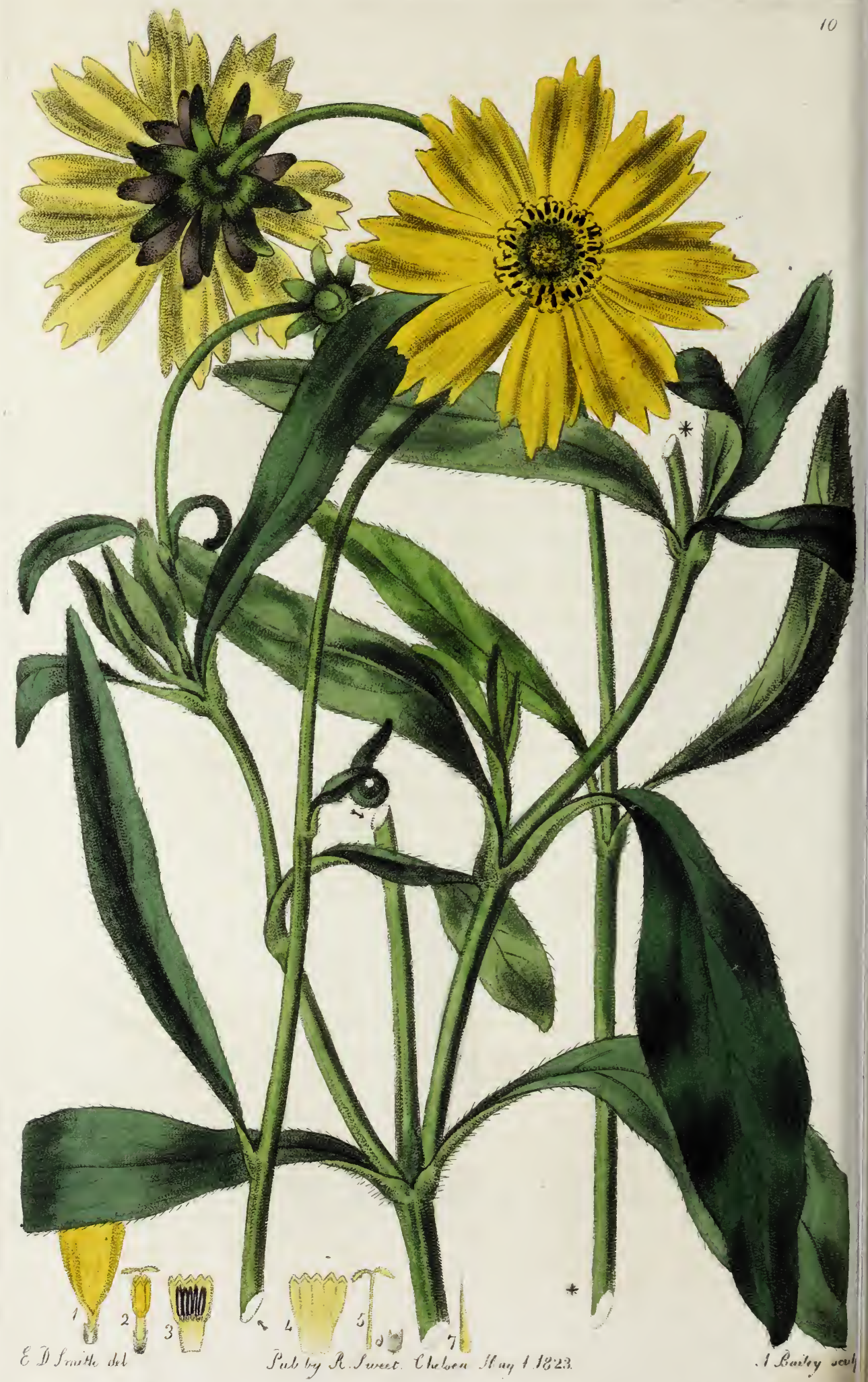




\title{
COREOPSIS lanceolata.
}

\author{
Spear-leaved Coreopsis.
}

Natural Order. Composite. Adanson fam. 2, 103.

COREOPSIS. (Radiata; Pappus aristatus; Receptaculum paleaceum.) Involucrum polyphyllum, foliolis a receptaculi paleis vix aut parum distinctis. Recept. planiusculum v. leviter convexum. Flosc. disci hermaphroditi, fertiles; radii feminii s. neutris ; ligulis disco transverso æqualibus s. longioribus, steriles. Pappus 2-3-aristatus; aristis glabris s. retrorsum scabris. Giart. sem. 2, 457.

Herbæ erecta ; folia sapius opposita, in quibusdam multifida; flores axillares et sapius terminales; ligula quarumdam albida. Juss. gen. 188.

C. lanceolata, foliis lanceolatis integerrimis ciliatis basi in petiolum attenuatis, pedunculis elongatis nudis, radiis 4 -dentatis, seminibus alatis scabris apice bidentatis emarginatis.

Coreopsis lanceolata. Willd.sp. pl. 3. p. 2256. Mich. flor. amer. 2. p. 137. Pursh. fl. amer. 2. p. 567. Pers. syn. 2. p. 478. Hort. Kew. ed. 2. v. 5. p. 135.

Bidens succisæ folio, radio amplo laciniato. Dill. elth. 55 . t. 48. $f .56$.

Stems several from the same root, erect, branching. Leaves opposite, broad lanceolate, entire, smooth, slightly fringed, bluntish, base attenuated down the petiole; fringed at the base with long spreading white hairs. Peduncle long, naked, bluntly angular, furrowed, smooth, 1-flowered. Involucre of two series, many-leaved; scales of the outer series 9, leaf-like, lanceolate, bluntish, reflexed; of the inner 9 , membranaceous, oblong, pointed. Receptacle convex, warted. Chaff subulate, channelled, about the length 
of the florets. Rays very broad, barren, cuneate, toothed with 4 large unequal teeth, which are bluntly and unequally crenate, or slightly notched, strongly nerved underneath, and furrowed on the upper side, flat when first expanded, afterwards rolled back at the edges, of a bright yellow colour. Florets of the disk numerous, tubular, funnel-shaped, hermaphrodite, 5 -toothed, nerves alternating with the teeth. Stamens 5; filaments distinct; anthers connected, their points exserted. Style smooth, slender, half as long again as the floret. Stigmas 2, revolute, fringed. Seeds oblong, slightly winged with rough edges. Pappus of 2 short fringed teeth.

Our drawing was taken from a fine plant, sent by Mr. Shepherd from the Botanic Garden at Liverpool ; an establishment, we are informed, particularly rich in hardy perennial herbaceous plants. It is a native of North America; and, according to Pursh, is found growing in mountainous situations near Virginia, and Carolina, flowering from August to October; with us it flowers about the same time; and, if cultivated in rich light soil, will attain the height of 2 feet, or upwards. It is rather more tender than some other species of the genus, and prefers a dryish situation; it would be well to place some of them in a frame in Winter, where they can be protected from the severe frost; they can then be turned out in the open ground in Spring, and will succeed very well. They are readily increased by dividing at the root; or cuttings, planted under a hand-glass, will soon strike root.

1. Barren floret of the ray. 2. Floret of the disk. 3. The same spread open, showing the 5 connected anthers. 4. Floret spread open, showing the nerves alternating with the teeth. 5. Style terminated with 2 fringed stigmas. 6. Unripe seed, terminated with 2 fringed teeth. 7. Scale of the chaff. 


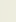




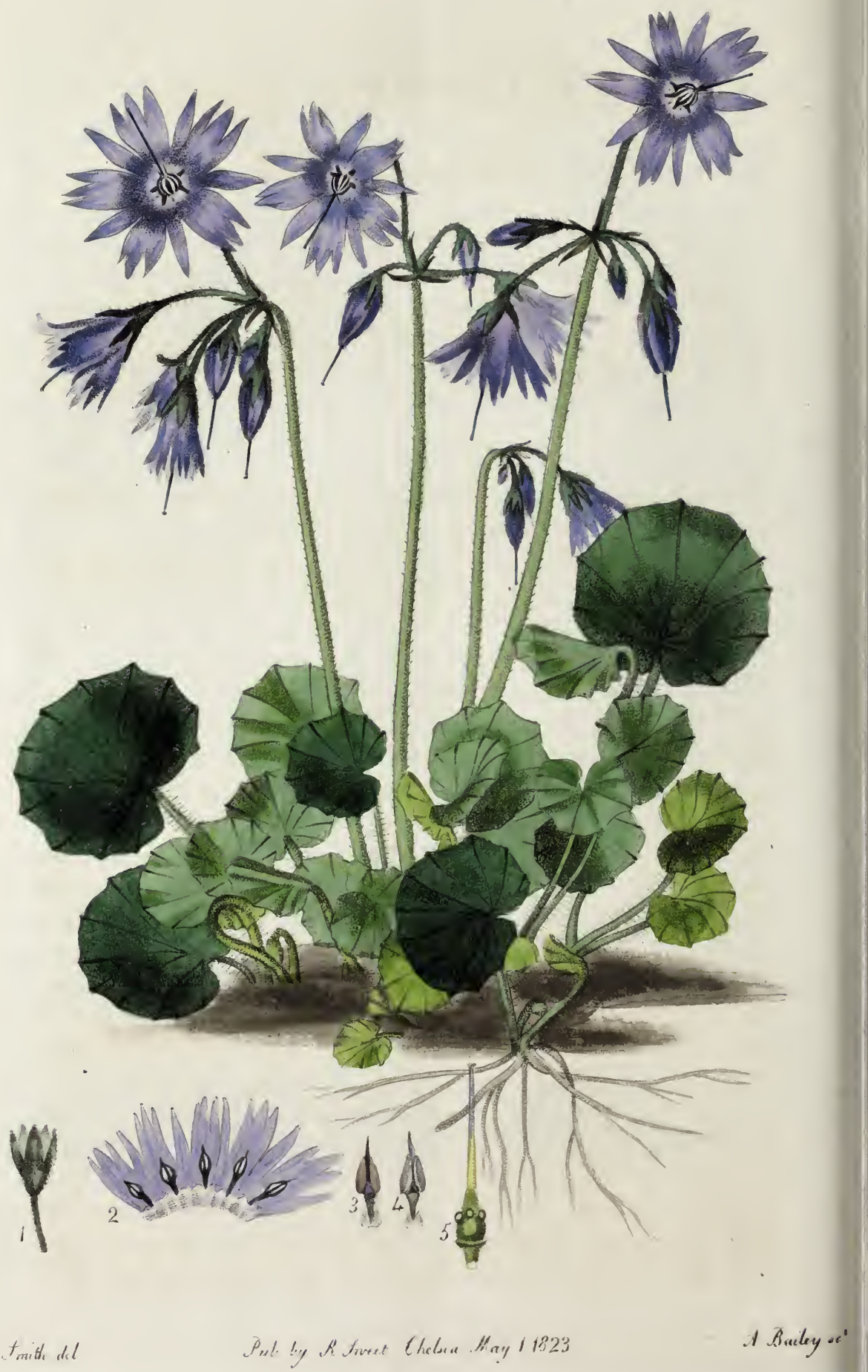




\section{1}

\section{SOLDANELLA montana.}

Mountain Soldanella.

Natural Order. Primulacex. Brown prodr. 427.

SOLDANELLA. Calyx 5-partitus. Corolla campanulata, ore lacero multifido. Stamina 5, filamentis antheras adnatas sagittatas superantibus. Stigma 1. Capsula apice multivalvis.

S. montana, foliis reniformibus crenato-repandis reticulatovenosis ; petiolis hirsutis, scapo multifloro.

Soldanella montana. Willd. enum. 1. p. 192. Link enum. 1. p. 158. Rœm. et Schult. syst. 4. 132. Hort. sub. lond. p. 33. Soldanella Clusii. Botan. magaz. 2163.

Root perennial, tufted. Stem none. Leaves reniform, waved, slightly crenate, reticulately veined, sinus generally overlapping at the base. Petioles nearly cylindrical, gradually tapering upwards, densely clothed with short white hairs. Scape slightly pubescent, gradually tapering upwards; from 4 to 8-flowered. Bractes 4 to 8, 1 at the base of each pedicle; unequal in length, the uppermost longest, smooth, ligulately-linear, obtuse. Pedicles very pubescent, unequal in length. Flowers nodding, of a pale blue colour. Calyx 5-parted, segments lanceolate, bluntish, slightly wrinkled. Corolla campanulate, mouth multifid, unequally and deeply lacerate. Stamens 5, inserted in the mouth of the corolla. Filaments flat and reaching beyond the anthers, terminating in a simple subulate point. Anthers joined to the front of the filament, 2-celled. Pollen white, farinaceous. Germen smooth, with 5 gland-like pellucid warts round 
it. Style smooth, gradually tapering towards the point, longer than the corolla. Stigma a small simple point.

A beautiful little alpine plant, introduced into our Gardens about seven years back. It differs from S. alpina, in being altogether more robust ; in bearing more flowers on each scape; the segments of which are larger, and spread more flatly open; the termination of the filament beyond the anther, is simple and subulate, and the petioles are densely hairy. In S. alpina, the scape is few-flowered; the flowers are more finely fringed, and bell-shaped; the filament beyond the anthers terminates in a bifid point; the leaves are narrower, more entire, and the petioles smooth.

Our drawing was taken from a plant at the Garden belonging to the Apothecaries Company, at Chelsea, in March last. When cultivated in the open ground, it should be planted in a dry border, in peat soil, which it prefers ; or it may be grown in rock-work, where it must also have peat soil, or it will not thrive so well ; it may also be cultivated, with advantage, in small pots, and can then be protected in a frame in severe weather. It is increased by dividing at the root, or by seeds; if by the latter method, they should be sown as soon as ripe, and planted off into other pots while in their seed leaf; they will then not miss their removal.

1. Calyx. 2. Corolla spread open, showing the insertion of the Stamens. 3. Back view of the Stamen magnified. 4. Front view of ditto. 5. Germen, Style, and Stigma magnified. 


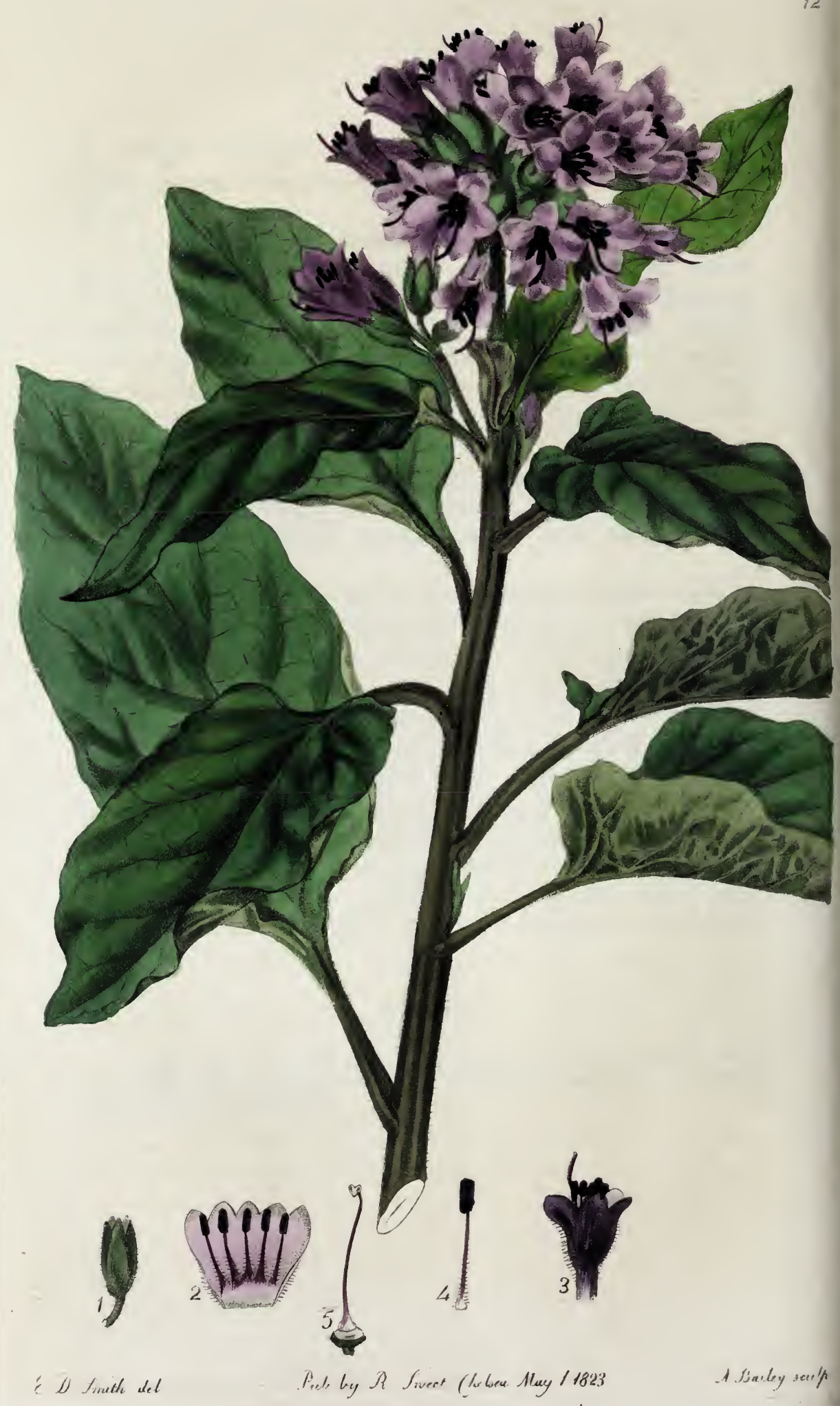




\title{
HYOSCY AMUS orientalis.
}

\author{
Oriental Henbane.
}

Natural Order. Solanes. Juss. gen. 124.

HYOSCYAMUS. Calyx tubulosus 5-fidus. Corolla infundibuliformis, obtusa. Stamina 5, inclinata. Stigma capitatum. Capsula operculata, 2-locularis. Herbæ; folia floralia sape geminata; flores solitarii axillares $v$. aggregati terminales, sape secundi.

H. orientalis, foliis ovatis repando-dentatis integerrimisve acutis pubescentibus, floribus terminalibus aggregatis; calycibus oblongis pubescentibus, caule villoso.

Hyoscyamus orientalis. Marsch. Bieb. flor. taur. cauc. v. 1. Røm. et Schult. syst. 4. p. 312. Link enum. v. 2. p. 178.

Root perennial. Stems several, springing from the same root, simple, erect, slightly angular, furrowed, thickly clothed with unequal villous hairs. Leaves ovate, repandly-dentate, or entire, attenuated down the petiole, pointed, glossy ; veins hairy. Petiole downy, shorter than the blade of the leaf. Flowers terminal, aggregate, trichotomously-corymbose, of a brownish lilac colour. Bractes ovate, obtuse, downy. Peduncles scarcely as long as the calyx, villous. Calyx oblong, 5-toothed, ribbed, downy. Corolla funnelform, 5-cleft, ribbed, downy; segments obtuse. Stamens 5, inserted into the tube. Filaments villous at the base, and smooth upwards; at first, included in the tube, but, at length, growing beyond the mouth. Anthers sagittate, incumbent, 2-celled. Pollen bluish, or ash-coloured. Germen slightly hairy, or sometimes smooth. Stigma capitate, emarginate. 
This pretty Spring flowering plant was raised from seed, received from Moscow, by Messrs. Whitley, Brames, and Milne, at Fulham, in the year 1818. It is nearly related to $\mathbf{H}$. physaloides, but is of much stronger growth, and thickly covered with pubescence, and its anthers are exserted beyond the mouth of the corolla; whereas $\mathbf{H}$. physaloides is quite smooth and shining, its flowers are of a beautiful dark purple, and its anthers are included within the mouth; they both are in flower at the same time, and are very desirable by being so early in bloom.

The present plant is a native of Iberia; it is quite hardy, and thrives well in any common garden soil, flowering the latter end of March, and beginning of April, and continuing in bloom a considerable time; in poor soil it will scarcely exceed a foot in height, but in stronger soil it will attain 18 inches, or more. It is increased by dividing at the root, or by seeds.

Drawn at the Nursery of Messrs. Whitley and Co. the beginning of last month.

1. Calyx. 2. Front view of the Corolla spread open to show the insertion of the Stamens. 3. Back view of the same in a more advanced state, in which the Anthers are exserted. 4. Stamen. 5. Germen, Style, and Stigma. 


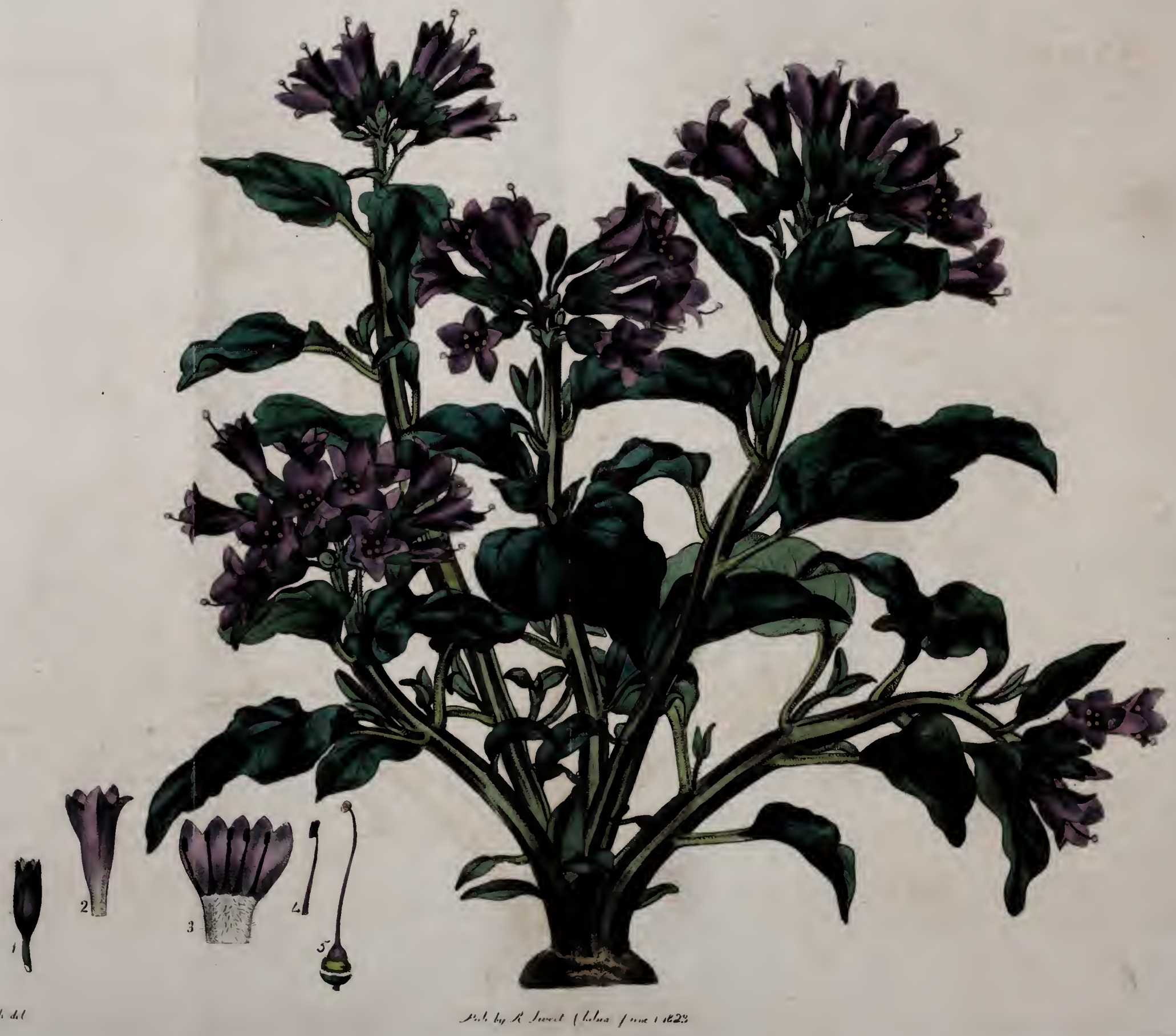




\title{
13
}

\section{HYOSCY AMUS physaloides.}

\author{
Purple-flowered Henbane.
}

Natural Order. Solane HYOSCYAMUS. Supra fol. 12.

H. physaloides, foliis ovatis acutis repandis integerrimis glabris, floribus terminalibus, calycibus inflatis angulatis glabris, staminibus corolla parum brevioribus.

Hyoscyamus physaloides. Willden. sp. pl. 1. p. 1012. enum. 229. Pers. syn. 1. p. 217. Botan. magaz. 852. Hort. Kew. ed. 2. v. 1. p. 389. Rom. et Schult. syst. 4. p. 312.

Root perennial, herbaceous. Stems several from the same root; angular, smooth and glossy, of a pale purple colour, seldom attaining a foot in height. Leaves alternate, ovate, acute, entire, repand, attenuated down the petiole, smooth and glossy, purple whilst young, afterwards changing to green on the upper side, and purplish underneath. Petioles shorter than the leaves, smooth and shining. Flowers terminal, paniculately corymbose, of a bright bluish purple. Bractes of various sizes, some as long as the peduncles, others not half the length, lanceolate, acute, concave. Peduncles purplish, about half the length of the calyx, with a few hairs scattered on them here and there. Calyx 5-cleft, tubular, inflated, 10-angled, reticulately veined, smooth; segments fringed. Corolla of a bright blue purple, funnel-form; tube slender at the base, gradually widening upwards, inside thickly clothed with hairs at the base of the filaments ; border 5-cleft, spreading, segments blunt and rounded. 
Stamens 5, inserted in the tube; filaments hairy at the base, and smooth upwards, of a pale purple colour; anthers incumbent. Pollen white. Germen pyramidal, smooth, green at the base, and purple at the point. Style smooth, purple. Stigma white, capitate, emarginate.

One of our handsomest early Spring flowering plants; a native of Siberia, seldom to be met with in any collection, though certainly deserving of cultivation much more than a great many that are more generally cultivated ; we suspect the reason of this is, from its being so little known; and have, therefore, given a fine specimen of it in our figure, that it may no longer remain in obscurity. It is a very hardy plant, thriving well in a rich light soil, and continues in flower for several weeks, beginning to blossom in March, and sometimes lasts in bloom till the beginning of May. It may be increased by dividing at the root, or by cuttings planted under a hand-glass; it also produces ripe seeds, which should be sown as soon as gathered.

Drawn at the Nursery of Mr. Colvill, in April last.

1. Calyx, showing its fringed segments. 2. Corolla. 3. The same split open, showing the insertion of the stamens, natural size. 4. Stamen. 5. Germen, Style, and Stigma, magnified. 


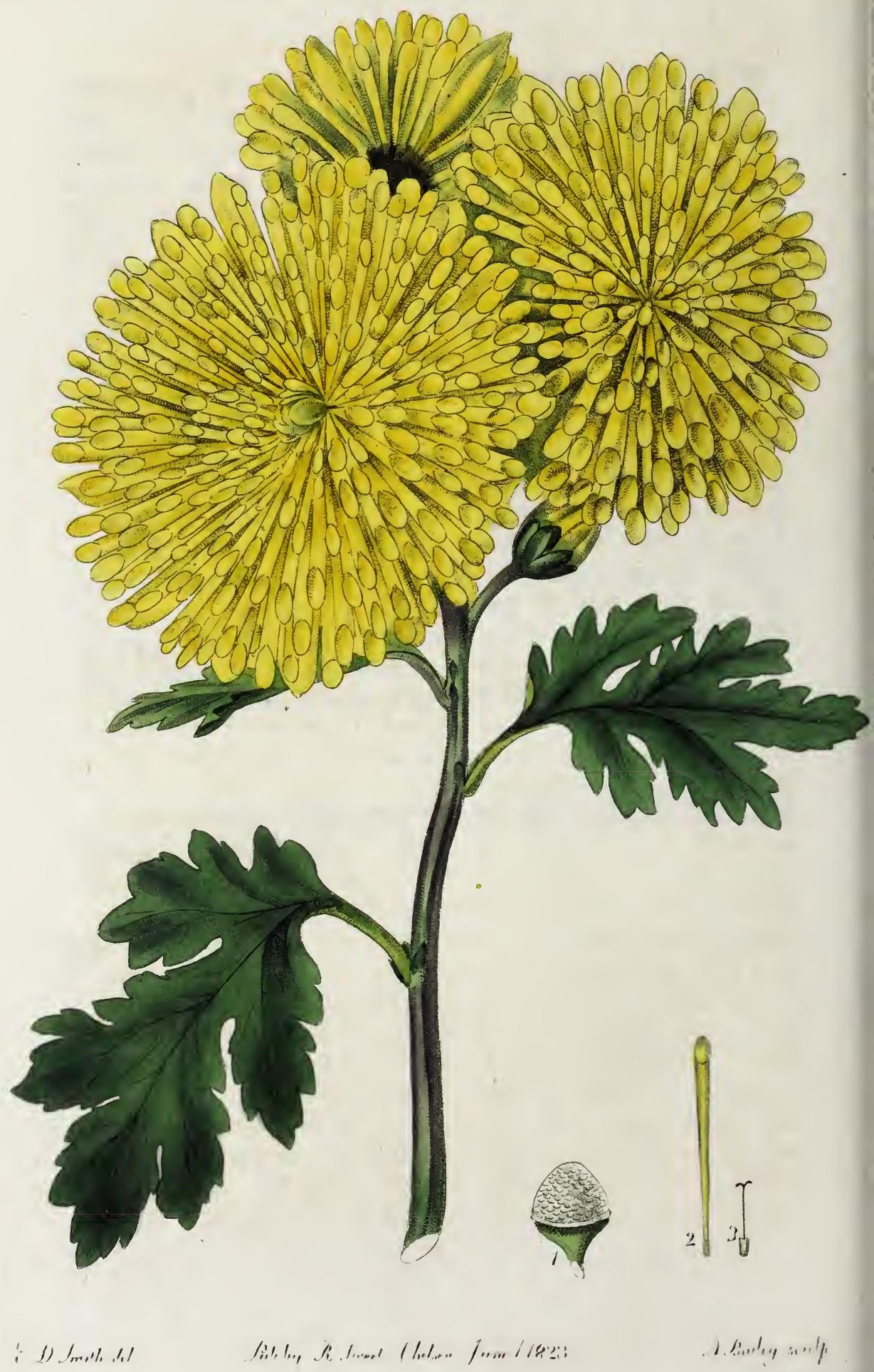




\section{CHRYSAN'THEMUM sinense,}

\section{var. fasciculatum.}

Superb Clustered Yellow Chrysanthemum.

Natural Order. Composite. Adanson Fam. 2. 103.

CHRYSANTHEMUM. Supra fol. 7.

Chrysanthemum sinense. Supra fol.7.

fasciculatum, floribus plenis fasciculato-corymbosis; radiis tubulosis luteis apice vix expansis, receptaculum nudum conico-globosum punctatum.

Root perennial, tufted. Stems ligneous, erect; in our specimen, about 3 feet high, slightly branched, and terminated with a fasciculated corymbus of flowers; branches a little flexuose, obtusely angular, of a purplish brown colour, thickly clothed with a dense white tomentum. Leaves of various forms, punctate, sinuately-lobate, and toothed with unequal bluntish teeth, of a dull green on the upper side, and clothed with a dense white tomentum on the lower; segments wide apart, blunt, and rounded at the ends, terminated in a very short point; lower ones about 4 inches long, to 3 broad. Petioles winged, channelled on the upper side, and bluntly keeled on the lower.'Stipules variable, oblong, obovate or spatulate, obtuse, sometimes toothed. Peduncles short, densely tomentose. Involucre hemisphærical, composed of numerous oblong or lanceolate membranaceous scales, overlapping each other. Flowers double, bright yellow. Receptacle naked, dotted, between conical and globular. Rays 
all quilled, scarcely expanded at the points, except here and there one expanded nearly half way down. Florets of the disk none. Stamens none, or barren. Style and Stigmas short and slender, imperfect.

Our figure represents another beautiful variety of the Chinese Chrysanthemum, lately introduced into the Garden of the Horticultural Society, and from thence distributed to other collections; in our opinion, the present variety is the handsomest of all the yellow ones, and differs from all others in its compact cluster of flowers; it is one of the varieties that is most proper for planting out in the open ground, as it begins flowering earlier than many of the others; like the rest, it may be readily increased by dividing at the root, or by cuttings planted under hand-glasses; when grown in pots, they are the most proper plants for ornamenting rooms, or greenhouses, in Autumn.

The present variety has, in general, a naked receptacle, or is very slightly chaffy ; some of the others are thinly, others thickly clothed with chaff; our opinion is, that the chaffy ones are mules, and have been fertilized by the Chinese with the pollen of some species of Anthemis, perhaps A. apiifolia, or some nearly related species.

1. The naked dotted receptacle. 2. Floret. 3. Germen, Style, and Stigma. 


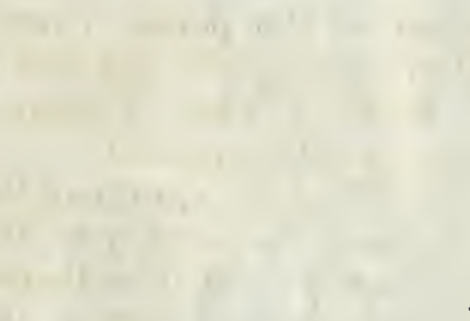




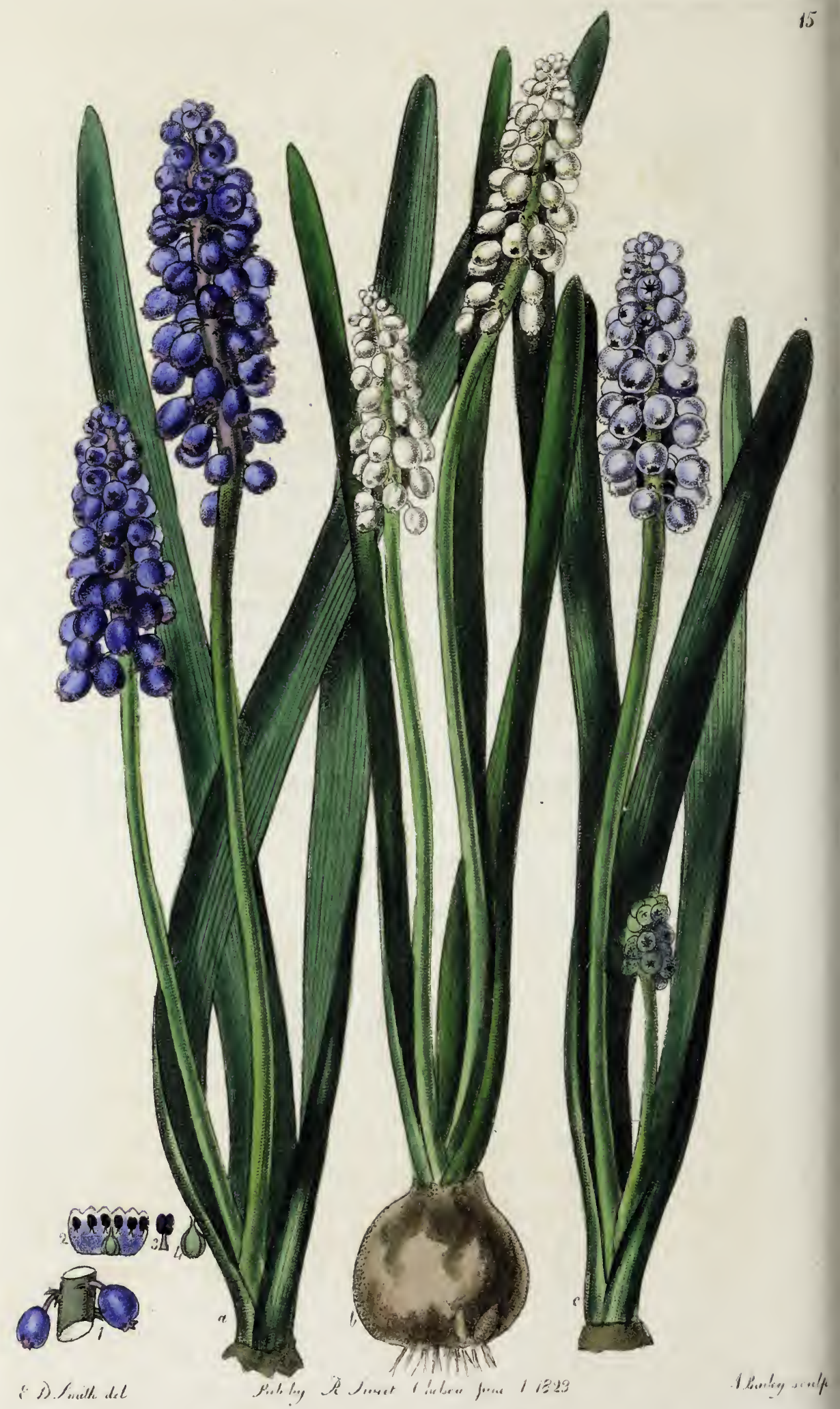




\title{
15
}

\section{MUSCARI botryoides, $\alpha, \beta, \gamma$.}

\author{
Grape Muscari, three varieties.
}

Natural Order. Asphodelex. Brown prodr. 274.

MUSCARI. Perianthium coloratum, ventricoso-tubulosum; fauce coarctata, crenis sex brevissimis marginata. Stamina 6, tubo medio inserta. Stigma 1. Capsula loculis sæpius 2-spermis.

M. botryoides, perianthiis globosis uniformibus; inferioribus remotioribus, foliis strictis linearibus basi angustatis canaliculatis.

Muscari botryoides. Willd. enum. 1. p. 378. Link enum. 1. p. 331. Hort. sub. lond. p. 73.

Hyacinthus botryoides. Willd. sp. pl. 2. p. 170. Pers. syn. 1. p. 375. Botan. magaz. 157. Hort. Kew. ed. 2. v. 2. p. 283.

a. azureum, floribus azureis. Sky-blue Grape Muscari. fig. a. ß. pallidum, floribus pallidis. Pale-blue Grape Muscari. fig.c. r. album, floribus albis. White Grape Muscari. fig. b.

Root bulbous, increasing rapidly by its numerous offsets. Leaves several, smooth, erect, linear, channelled, bluntish, narrowest at the base. Scapes generally 2 from the same bulb, erect, about the length of the leaves, smooth, round on one side, and flat on the other, slightly angular. Flowers in a crowded cluster, globular, all of the same form, lowermost farthest apart, nodding. Bractes 2, at the base of the peduncle, 1 on each side, very short, succulent. Peduncles cylindrical, shorter than the flowers, more than double the length of the bractes. Perianthium globular, mouth contracted, and terminated in 6 slight margi- 
nated notches. Stamens 6 , inserted in the middle of the tube; filaments widest at the base, and narrowing upwards ; anthers cordate, incumbent, 2-celled. Germen trigonal. Style about the length of the stamens.

The three varieties represented in our figure are very desirable plants for adorning the flower-borders in Spring, where they may be planted in patches in conspicuous situations, either mixed together, or separate, according to the taste of the Cultivator. The pale blue variety is the least common, and, in our opinion, is the most beautiful; they all increase readily by offsets from the bulbs, and thrive well in a rich light soil, flowering in April, some time before M. racemosum.

Our drawing was taken from plants at the Nursery of Mr. Colvill; we also received specimens of the darkest blue and white varieties, from Mr. Milne, of the Fulham Nursery.

1. Magnified portion of the scape, showing the bractes at the base of the flowers. 2. Perianthium spread open, showing the insertion of the stamens. 3. Stamen detached. 4. Germen, Style, and Stigma, magnified. 


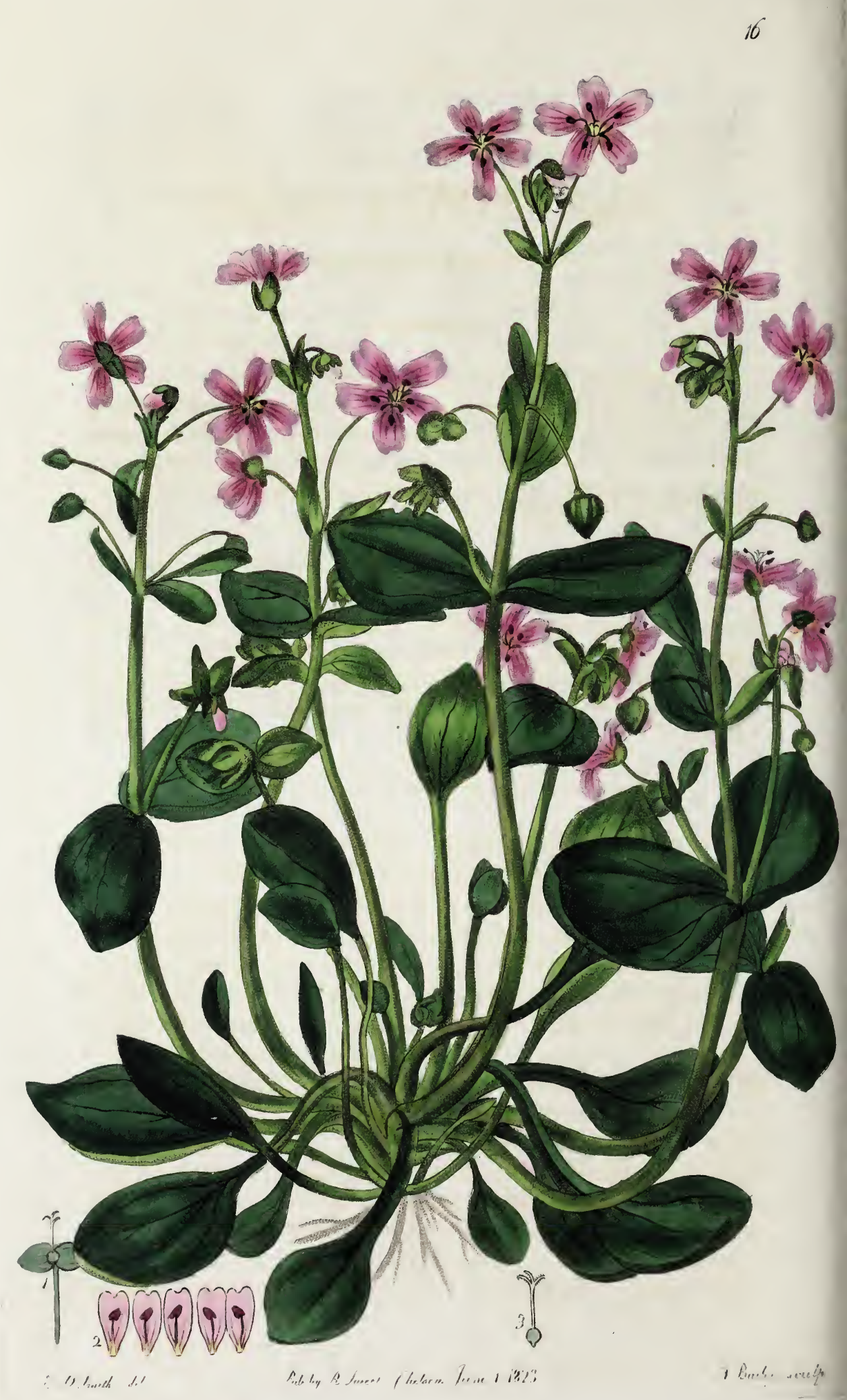




\title{
CLAYTONIA sibirica.
}

\author{
Siberian Claytonia.
}

Natural Order. Portulacea. Juss. gen. 312.

CLA YTONIA. Calyx 2-valvis. Petala 5 subunguiculata. Stamina 5, unguibus petalorum inserta; antheræ incumbentes. Stylus 1; stigmata 3. Capsula 3-valvis, 1-locularis, 3-sperma. Herbæ; folia radicalia; scapus opposite 2-phyllus, apice racemoso-multiflorus.

C. sibirica, foliis nervosis: radicalibus caulinisque ovatis, racemo secundo, petalis bifidis. Willd. sp. pl. 1. p. 1186.

Claytonia sibirica. Pers. syn. 1. p. 253. Hort. Kew. ed.2. v. 2. p. 53. Røm. et Schult. syst. 5. p. 435 . Botan. magaz. 2243.

Perennial. Herbaceous. Roots tufted. Branches short, numerous, much crowded together. Leaves succulent, ovate, bluntish, deeply nerved, smooth and glossy ; lower ones petiolate, and attenuated down the petiole; upper ones, or those on the scape sessile, the two lower ones opposite. Petioles smooth, channelled on the upper side, dilated at the base, and sheathing the stem. Scapes axillary, declining, smooth and glossy, generally terminated with 2 racemes of flowers, one of them beginning to flower about the time the other appears. Racemes secund, or leaning to one side, drooping till the flowers expand, then becoming erect. Pedicles intermixed with the bracte like leaves, slender, smooth and glossy. Calyx 2-valved. Sepals cordate, concave, bluntish. Petals 5, bifid, of a bright lilac, streaked, and lightest at the edges, 
unguiculate. Stamens 5, inserted in the claws of the petals. Filaments declining. Anthers red, incumbent. Style smooth. Stigmas 3, blunt, slightly reflexed.

A handsome little perennial plant, attaining but a few inches in height, and very desirable for ornamenting rock-work, or planting at the front of flower-borders; it may also be cultivated with advantage in small pots, and will continue to flower the greater part of the Summer; it prefers a light sandy soil, and may be increased by cuttings, which soon strike root if planted in a shady situation; it also produces seeds, by which a sufficient quantity may be raised.

Drawn at the Nursery of Mr. Colvill, from a plant raised last year from seed, sent by Dr. Fischer, from the Botanic Garden at Gorenki.

1. The 2-valved Calyx. 2. Petals spread open, showing the insertion of the Stamens. 3. Germen, Style, and Stigma. 



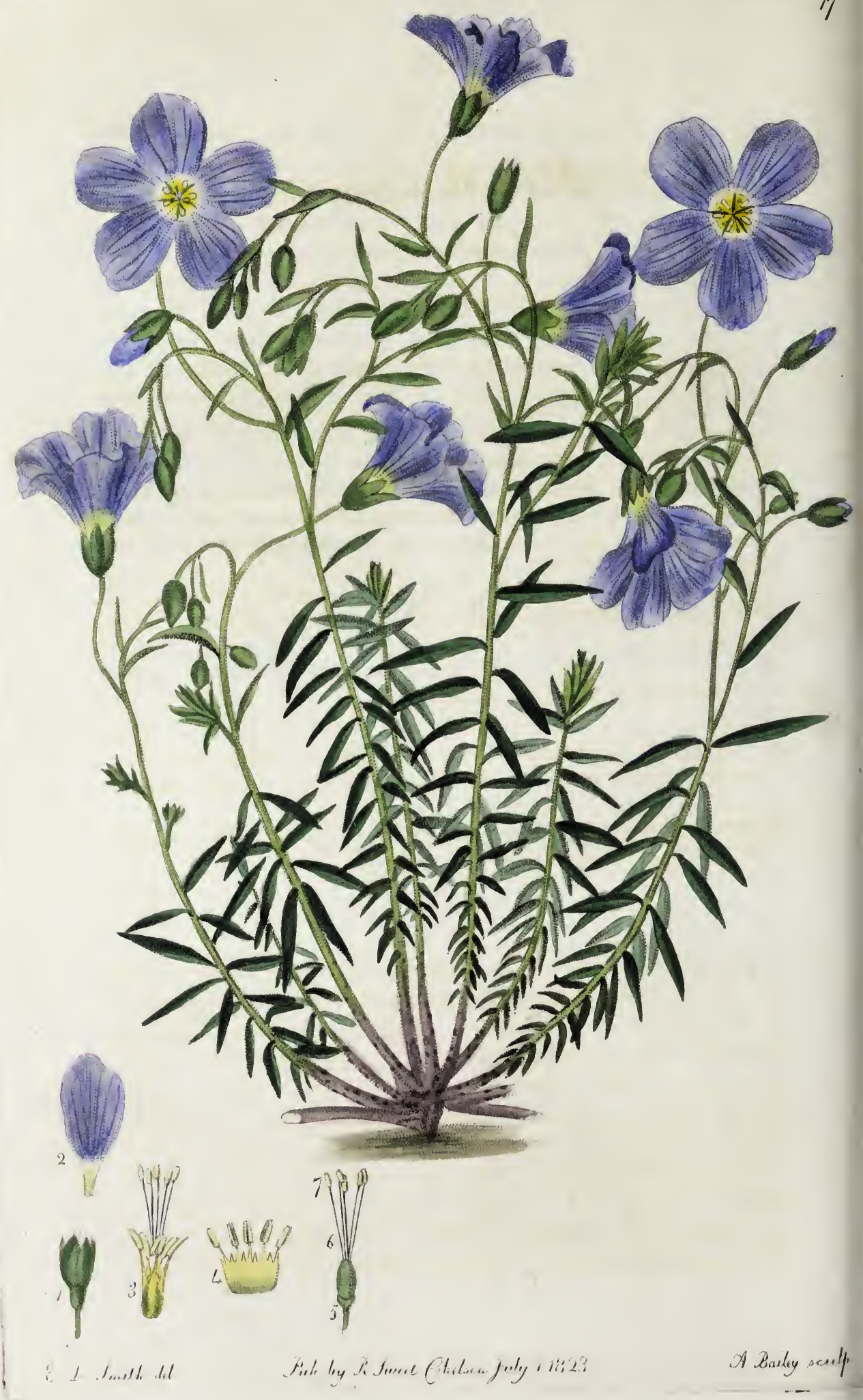




\section{7 \\ LINUM alpinum. \\ Alpine Flax.}

Natural Order. LiNex. DC. theor. ed. 1. p. 214.

LINUM. Calyx 5-sepalus. Petala 5 unguiculata. Staminum filamenta 10, basi in annulum connata, alterna fertilia antheris sagittatis, alterna breviora sterilia. Styli 5 ; stigmata 5 . Capsula 5-valvis, 10-locularis. Semina solitaria.

Herbæ aut suffrutices; folia plurimorum alterna, pauciorum opposita; flores solitarii axillares aut rarius oppositifolii, apice corymbosi aut spicati aut sparsi, in L. radiola, (Radiola millegrana,) 4-andri 4-styli. Genus a Caryophylleis distinctum staminibus basi monadelphis, nullo nec receptaculo fructus centrali nec seminis perispermo, foliis sape alternis. Juss. gen. 303.

L. alpinum, calycibus rotundatis obtusis, foliis linearibus acutiusculis subreflexis, caulibus declinatis. Jacq. aust. 4. $t .321$.

Linum alpinum. Willden. sp. pl. 1. p. 1538. Pers. syn. 1. p. 335. Hort. Kew. ed. 2. v. 2. p. $10 \%$.

Perennial. Stems several, declining, smooth at the points, and rough at the base; slightly branched, from 5 to 9 inches in length. Leaves alternate, linear, smooth and glaucous, spreading or reflexed; lower ones much the shortest, and bluntish; upper ones longer, taper-pointed. Corymbus terminal, pendulous before the flowers expand, afterwards becoming erect. Peduncles alternating with the leaves, slender, cylindrical. Sepals 5, lanceolate, concave, bluntly rounded, but ending in a small point. Petals 5, unguiculate, obovate, of a light blue, tinged with purple, and darker 
veins; claws hairy. Stamens connected at the base, hairy; filaments 10,5 bearing anthers, and 5 sterile; sterile ones alternating with the others, very slender and filiform, and scarcely half the length of the fertile ones; anthers sagittate, 2-celled. Styles 5, slender, about double the length of the stamens. Stigmas 5, incumbent, shield-like, granular.

Our drawing of this pretty little plant, was taken at the Nursery of Mr. Colvill, King's Road, Chelsea; where it continues to flower nearly all the Summer. It is a neat little plant, and will thrive well on rockwork, or at the edge of flower borders, in a light sandy soil, in a dryish situation, and being of small growth, it requires but little room. It might also be cultivated with advantage in small pots. Being a native of Austria, it is quite hardy, and is more liable to suffer from damp than from cold; it may be increased from cuttings, taken off in a young state, and planted under a hand-glass, where they will soon strike root; it also ripens seeds, which should be sown as soon as gathered, and they will soon make nice young plants.

1. Calyx. 2. Petal. 3. The 5 Stamens connected at the base, alternating with 5 sterile filaments, and inclosing the Germen and 5 Styles. 4. The same split open, showing the 5 barren Filaments. 5. Germen. 6. Styles. 7. Stigmas. 



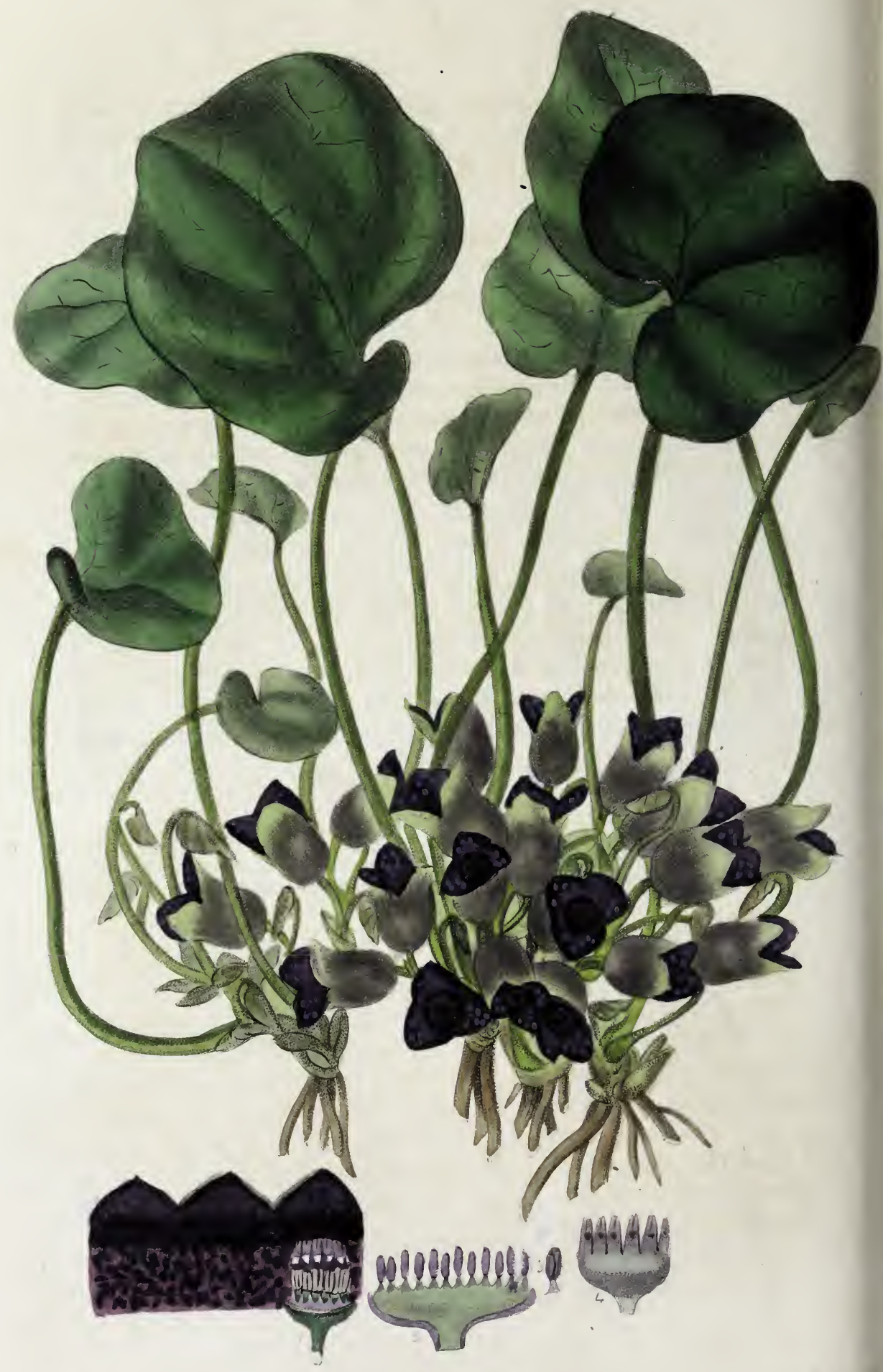




\title{
18
}

\section{ASARUM virginicum,}

\author{
Virginian Asarabacca.
}

Natural Order. Aristolochiz. Brown prodr. 349.

ASARUM. Perianthium coloratum, urceolatum, 3-s. 4-fidum, germini insidens. Stamina 12 brevia, germini imposita; antheræ mediis filamentis adnatæ. Stylus brevis; stigma stellatum 6-partitum. Capsula 6-locularis.

A. virginicum, foliis solitariis rotundato-cordatis obtusis glabris petiolatis, perianthium extus glabrum breviter campanulatum. Asarum virginicum. Mich. flor. amer. 1. p. 279. Willden. sp. pl. 2. p. 838. Pers. syn. 2. p. 1. Pursh. fl. amer. sept. p. 597. Hort. Kew. ed. 2. v. 3. p. 141.

Perennial. Root tufted. Branclies very short, 1-leafed, 1-flowered. Leaves roundly cordate, obtuse, entire, smooth and shining, strongly veined underneath, and marked with white on the upper side, similar to Cyclamen vernum, or persicum. Petiole long and slender, furrowed on the upper side, and convex on the lower. Bractes 2, cucullate, fringed, one double the size of the other. Flowers on short footstalks. Peduncle cylindrical, 1-flowered, smooth, or slightly pubescent. Perianthium short, campanulate, trifid, smooth on the outside, of a pale brown colour, segments straight, obtuse; inside dark purple, rugged and plaited below the mouth; segments spotted with white, pubescent. Stamens 12 , short, every other one longest, seated on the germen. Slyle scarcely any. Stigma stellately 6-parted, segments 
bluntish, slightly curved inwards, each having a large pale gland, or protuberance, about half way up.

According to Pursh, the present curious species grows in shady rocky woods, near Virginia and Carolina, flowering in May; with us it blooms much earlier, as our drawing was taken at the Nursery of Mr. Knight, King's Road, the middle of April; and it had then been in flower a considerable time, although the season was very backward; but it continues in flower a long time, as some of them are still remaining, now, about the middle of June. It thrives best in a peat soil, in a shady situation; in such it was cultivated at Mr. Knight's Nursery, where there was a large clump of it entirely covered with bloom; the flowers, though not so splendid as some others, are pretty, and very curious; and as they continue a long time, the plant is well worthy a place in all curious collections. It may be grown in rock-work, if in a shady situation, and the ground should then be made with peat; it is readily increased by dividing at the root.

1. Perianthium spread open, to show the plaited inside, and the insertion of the stamens inclosing the stellately 6-parted stigma, with the large gland on the middle of each segment. 2. Stamens spread open, every other one shortest, seated on the germen. 3. Back view of a detached stamen. 4. Germen, with the short fleshy style, and stellated stigma split open, to show the glands on the inside, all magnified. 


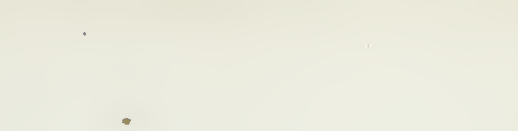




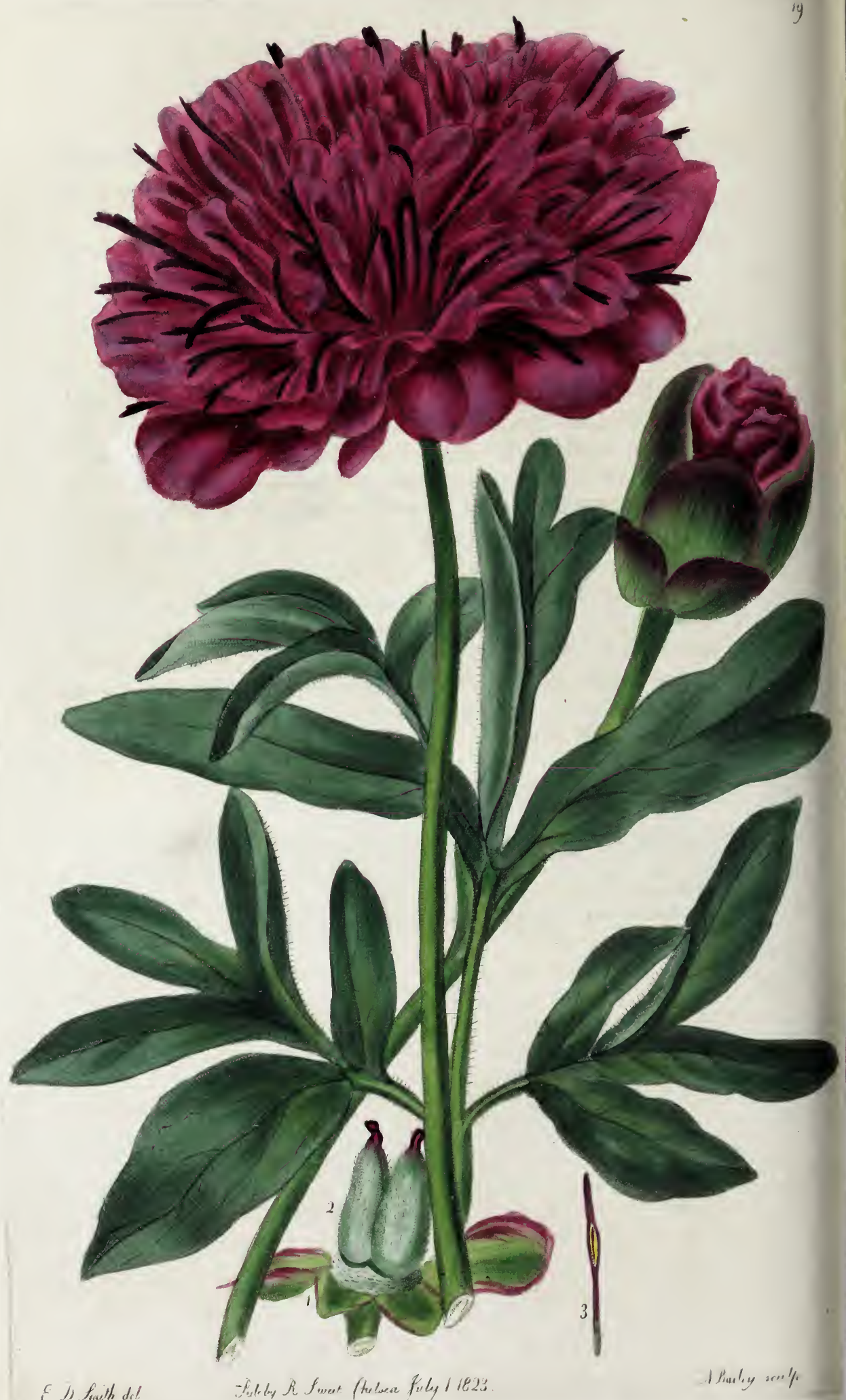




\title{
PAONIA paradoxa $\beta$, fimbriata.
}

\author{
Double fringed Paony.
}

Natural Order. Ranunculaces. DC. Reg. veg. syst. nat. 1. $p .127$.

Div. II. Ranunculaceæ spuriæ, seu Antheris introrsis.

PAEONIA. Calyx 5-sepalus, sepalis subfoliaceis inæqualibus orbiculatis persistentibus. Petala 5 (interdum 6-10) orbicularia subæqualia ungue destituta. Stamina plures, antheris introrsis; discus carnosus ovaria cingens; ovaria 2-5 grossa; stigmata sessilia crassa falcata bilamellata crispa; capsula (folliculive) 2-5, ovatæ, apice stigmate superatæ, 1-loculares, polyspermæ, sutura longitudinali superne dehiscentes. Semina subglobosa nitida; umbilicus prominulus; albumen carnosum; embryo in basi locatus.

Herbæ aut rarius suffrutices; radices perennés collo crasso subhorizontali, fibris fasciculatis extus nigricantibus aut omnibus aut aliis cylindricis, alteris in tubercula ovata cylindraceave incrassatis; vaginæ squamosa ad basim caulis; gemmæ radicales squamis petiolaribus constantes; folia alterna petiolata bis ternatin secta; flores terminales, ampli, purpurei rosei aut albi (nunquam nec carulei nec lutei,) facile multiplices. DC. syst. 1. p. 386-7.

P. paradoxa, foliolis multipartitis obtusis undulatis, subtus glauco-pilosis, germinibus adpressis tomentosis. Anderson in Linn. trans. v. 12. p. 280, cum synon.

Pæonia paradoxa. Hort. sub. lond. p. 124. Link enum. 2. p. 77.

a. simpliciflora, caule omnino glabro, floribus 8-petalis.

6. fimbriata, caule vix pilosiusculo, floribus plenis. Anders. loc. cit.

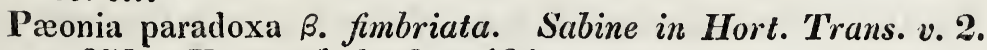
p. 276. Hort. sub. lond. p. 124.

Roots tuberous, slenderer than in most species, here and there knotted, spreading. Stem from a foot to 18 inches in height, simple, smooth, or slightly pubescent, furrowed. Leaves biternate; lower ones 
largest, and most divided; upper ones gradually smaller; segments ovate, or oblong, often bifid, or trifid; sometimes simple, bluntish, the upper ones a little pointed, flat, or slightly undulate, upper side naked, uneven, of a bright green; under side thickly clothed, with a whitish woolly pubescence. Petioles smooth, slightly decurrent, swollen at the base. Sepals 5, smooth, unequal, outer ones green, scarcely half the size of the inner ones, nearly round, pointed; inner ones nearly orbicular, retuse, green on the under side, and tinged with red on the upper. Flowers double, of a reddish purple. Petals 8 on the outside, obovate, slightly retuse, much veined; edges a little uneven, surrounding the numerous stamens that are transformed into narrow petals, with here and there a broad one intermixed. Pollen produced round the edges of some of these of a yellow colour. Germens 2 , erect, close pressed, thickly clothed with a white dense tomentum. Styles 2, flesh-coloured, hooked or reflexed.

This beautiful variety of P. paradoxa had generally passed in our Nurseries for a variety of P. humilis, until its species had been determined by the late Mr. Anderson, and Mr. Sabine, in the Horticultural and Linnean 'Transactions, where a masterly account of the whole that were known at that time in our gardens is given, with their synonyms.

The present variety is readily distinguished from the double ones of the other species, by its humbler growth, and pubescent leaves; it thrives well in the common garden soil, and is increased by dividing at the root. Our drawing was taken at the Nursery of Messrs. Whitley, Brames, and Milne, of the Fulham Nursery.

1. Calyx showing the unequal sepals. 2. Woolly Germens, crowned with the hooked fleshy style. 3. Stamen partly changed to a petal, showing the pollen ou its sides. 


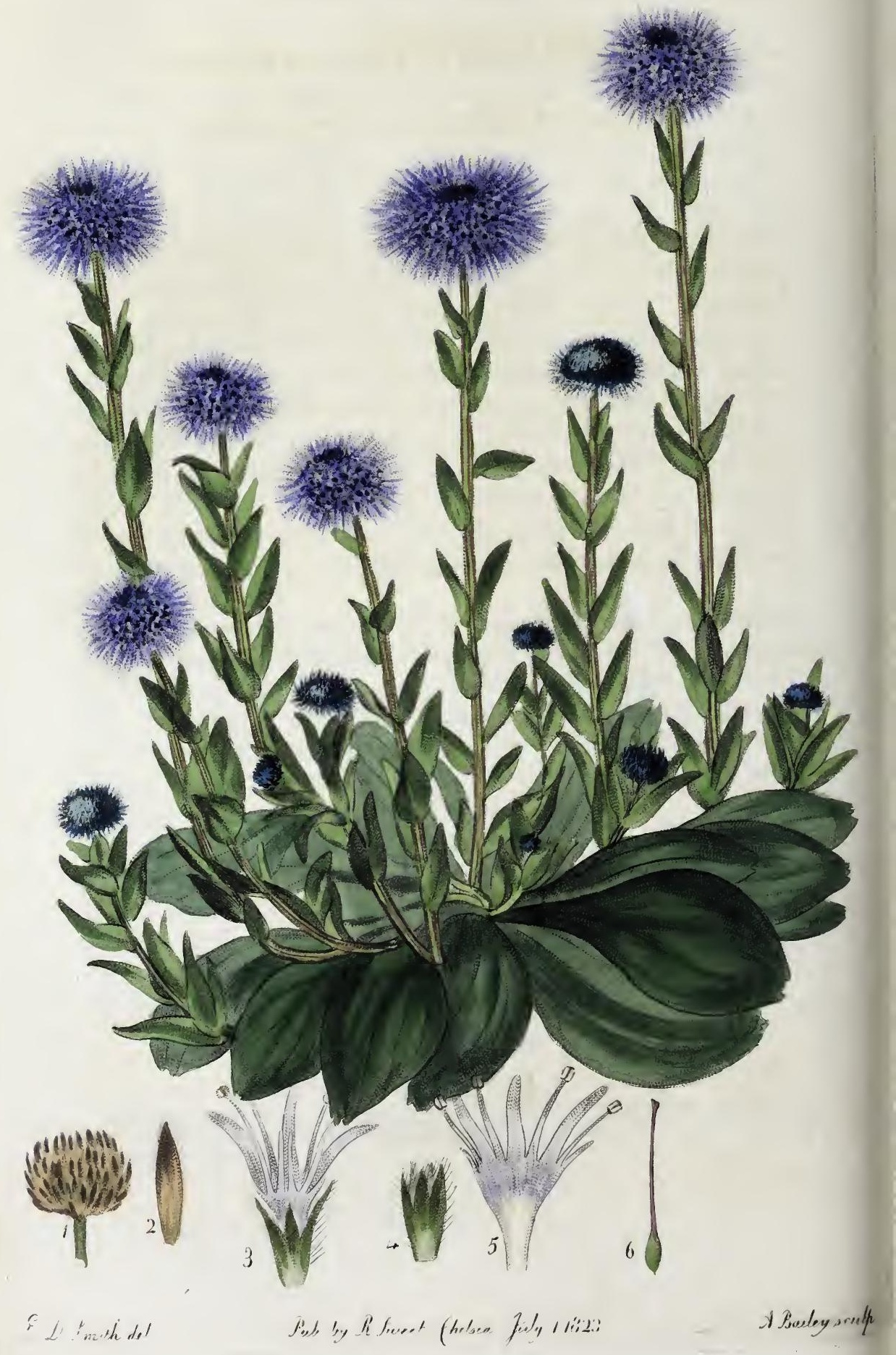




\section{GLOBULARIA vulgaris.}

Common Globularia, or Blue Daisy.

Natural Order. Globularine. Link enum. 1. p. 123.

GLOBULARIA. Calyx tubulosus 5-fidus persistens. Corolla tubulosa, 5-loba, inæqualis; laciniis 2 superioribus minimis. Stamina 4, tubo inserto (laciniis alterna?) Germen superum; stylus 1; stigma 1. Semen 1, calyce connivente tectum. Flores aggregati in calyce communi polyphyllo hemisphærico supra receptaculum commune paleaceum.

Caulis herbaceus simplex, apice 1-florus; folia radicalia sape spatulata, emarginato-acuminata; caulina parva aut subnulla. Discrepat G. Alypum calyce communi turbinato plurimum imbricato, corollâ ligulatâ tridentatâ, stigmate 2-fido, caule frutescente ramoso, habitu Protea; an genus diversum? Globularia a Monopetalis hypogynis et ideô à Lysimachiis distinctissima semine nudo et florum dispositione et habitu, indè Statice extùs similis non tamen affinis, similior fortè Proteis sed corollata, unica in suo ordine nondùm cognito, huic tanquàm viciniori nunc adjuncta. Juss. gen. 97.

G. vulgaris, caule herbaceo, foliis radicalibus tridentatis ; caulinis lanceolatis. Willden. sp.pl. 1.p. 540.

Globularia vulgaris. Pers. syn. 1. p. 118. Hort. Kew. ed. 2. v. 1. p. 222. Ram. et Schult. syst. 3. 39. Link enum. 1. p. 123. Schkuhr. handb. 1. p.65. t. 21. Botan. magaz. 2256.

Root perennial. Branches numerous, short, tufted. Leaves smooth and glossy ; lower ones petiolate, ovate, oblong, or spatulate, obtuse, generally terminated with 3 short bluntish teeth; stem-leaves scattered, small, sessile, lanceolate, or oblong, entire, acute. Flowerstem from 4 to 6 inches high, furrowed with numerous shallow channels. Flowers in a flattish head, about 
the size of a large cherry, of a bright blue. Receptacle chaffy. Scales of the chaff fringed, about the length of the calyx. Calyx tubular, hairy, 5-cleft, persistent; segments taper-pointed, fringed. Corolla tubular, 5-parted ; segments unequal ; 2 upper ones very small and slender. Stamens 4, inserted in the tube, and alternating with the larger segments. Style 1, terminated with an emarginate stigma.

The present beautiful plant is an old inhabitant of our gardens, though it is now very rarely met with; and we had never before seen it growing so luxuriantly, and flowering so abundantly, as we saw it this Spring, at the Nursery of Mr. Lee, at Hammersmith; it was cultivated in a bed of peat soil, several plants of it growing together, which made a fine appearance; and from one of them our drawing was taken. Being a short tufted plant, it might be grown with advantage on rock-work, but requires a light soil; it will also thrive well in pots, and may be increased by seed, or dividing at the root.

1. The chaffy Receptacle. 2. Scale of the chaff, fringed. 3. Calyx and Corolla. 4. Calyx divested of the corolla, and showing its fringed segments. 5. Corolla split open, showing the insertion of the stamens. 6. Germen, Style, and cleft Stigma, all magnified except the receptacle. 



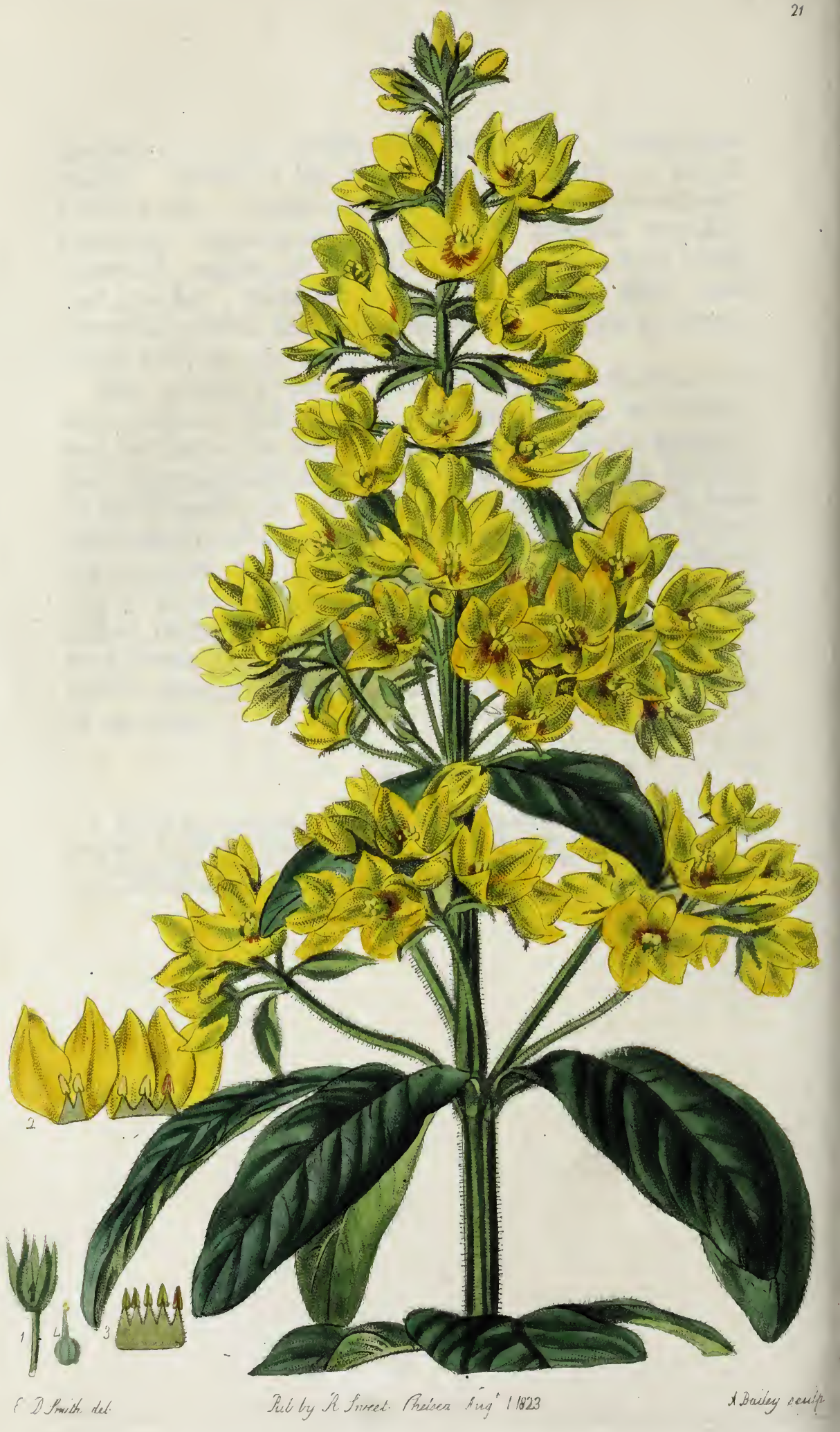




\title{
LYSIMACHIA verticillata.
}

\author{
Whorled Loose-strife.
}

Natural Órder. Primulacex. Brown prod. 427.

LYSIM ACHIA. Calyx 5-partitus. Corolla rotata, 5-fida. Stamina 5. Capsula globosa, 5-10 valvis. Folia opposita v. verticillata. Flores axillares $v$. terminales, solitarii v. spicati aut corymbosi. Brown prodr. $\mathbf{2 4 8}$.

L. verticillata, foliis verticillatis oblongo-lanceolatis ovatisque petiolatis molli-pubescentibus, pedunculis axillaribus unitriflorisque, petalis ovatis acutis glandulosa-ciliatis, caule pubescente.

Lysimachia verticillata. Willd. enum. 1. p. 195. Ram. et Schult. syst. 4. p. 124. Link enum. 1. p. 160. Nob. in Colv. catal. p. 36. col. 1.

Root perennial, turfy. Stems numerous, springing from the same root, from 1 to 2 feet high, simple, erect, channelled, thickly clothed with unequal woolly hairs. Leaves in whorls, 4 or 5 in each whorl; lower ones generally ovate, a little unequal at the base; upper ones oblong, or lanceolate, slightly undulate, rugose, bluntish, many nerved underneath, and channelled above; thickly clothed on both sides with short soft hairs. Petioles more than 3 times shorter than the leaves, deeply channelled above, and rounded below; winged, the wings continuing from the leaf down the stalk to the next leaves. Stipules none. Peduncles from the axils of the leaves, from 1 to 3 flowered, thickly clothed with unequal spreading hairs. Calyx 5-parted, about half the length of the petals; segments narrowly lanceolate, concave, acute, 
very hairy. Corolla rotate, of 1 petal, deeply 5-parted; segments ovate, acute, glandularly ciliate, and covered on both sides with a short glandular pubescence, of a palish yellow, with a brown circle at the base. Filaments 5, connected at the base; the upper ones rather the longest, all glandularly pubescent, and all bearing perfect anthers. Anthers slightly incumbent, cordate, 2-celled; bursting in front to discharge the pollen. Style green, smooth and shining, scarcely as long as the filaments; about the length of the calyx. Stigma simple.

This plant is related to L.ulgaris, but differs in its root being tufted, not creeping, the stem being simple, and altogether more pubescent; its leaves shorter and blunter, its calyx 3 times the length, and the corolla glandularly ciliate, besides other slighter differences. It is a very ornamental plant, beginning to flower in June, and continuing in bloom till late in Autumn; growing in strong ground to the height of 18 inches; in poorer soil it seldom exceeds a foot. It will, also, thrive very well in rock-work ; and being a native of Hungary and Tauria, it is quite hardy. It is readily increased by dividing at the root; it may also be raised from seeds, which succeed best if sown as soon as gathered. Drawn at the Nursery of Mr. Colvill, last October.

1. Calyx. 2. Corolla split open, showing the stamens connected at the base. 3. Stamens divested of the corolla, all joined at the base. 4. Germen, Style, and Stigma, all slightly magnified. 



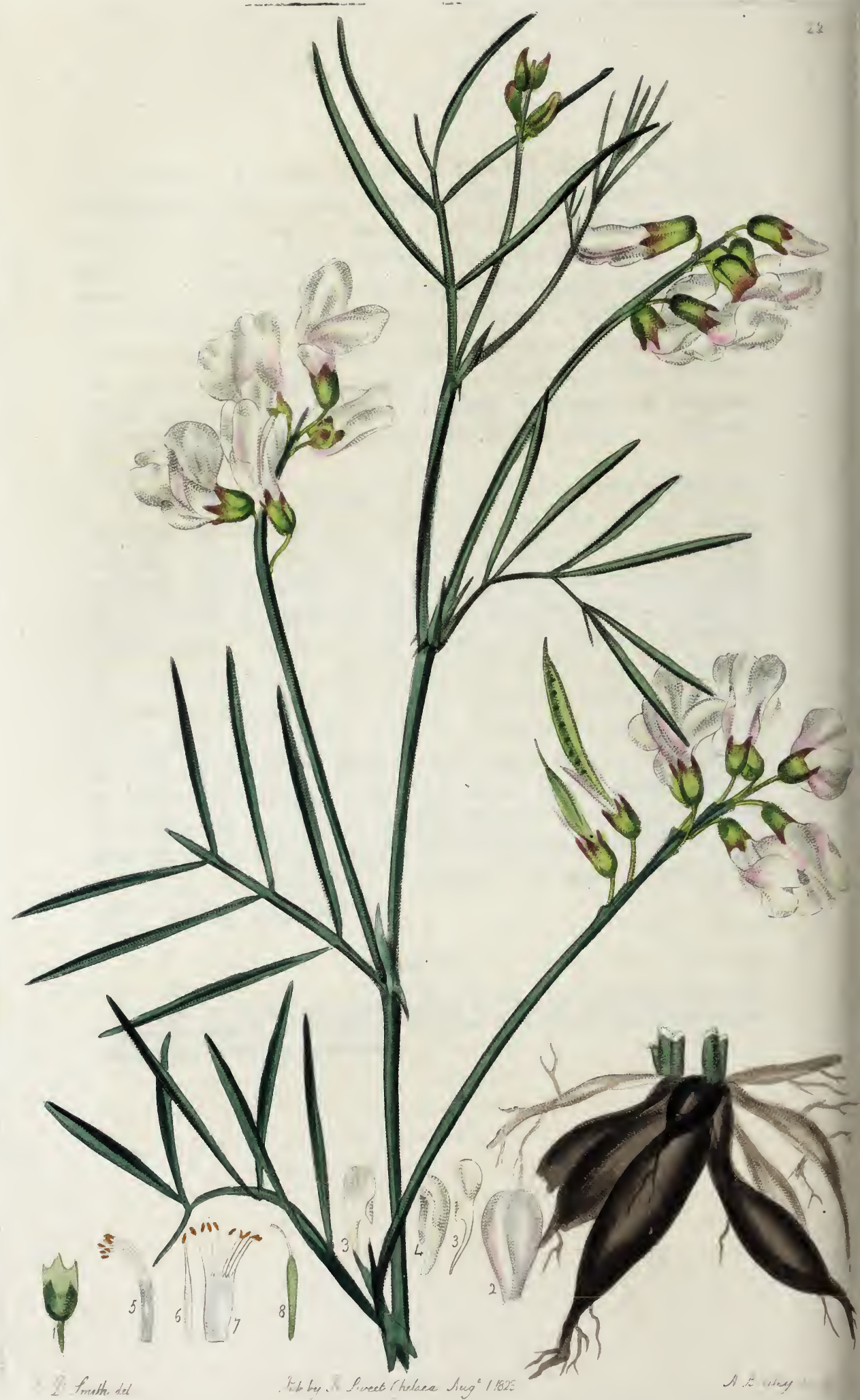




\section{OROBUS albus.}

\section{White-flowered Bitter-Vetch.}

Natural Order. Leguminosa. Juss. gen. 345.

Div. VII. (PAPILIONACEE.) Corolla irregularis papilionacea. Stamina decem diadelpha. Legumen uniloculare bivalve. Juss. gen. 359.

OROBUS. Calyx tubulosus, basi obtusus, limbo 5-dentatus dentibus 2-supernis brevioribus et profundioribus. Stylus linearis ; stigma superne villosum. Legumen oblongum polyspermum seminibus rotundis. Caulis sepe erectus. Folia conjugata, aut bijuga aut pinnata. Stipulæ auriculata. Flores spicati axillares et terminales. Juss. gen. 360.

O. albus, foliis bijugis ensiformibus petiolatis, stipulis lanceolatis semisagittatis, caule simplici superne alato.

Orobus albus. Willden. sp. pl. 3. p. 1075. Pers. syn. 2. p. 303. Hort. sub. lond.p. 164.

Orobus pannonicus. Jacq. aust. 1.p. 25. t. 39 .

Root tuberous, branching. Stems several from the same root, simple, erect, slender, triquetrous, furrowed, smooth and glossy, from 1 to 2 feet high. Leaves pinnate, producing 2 pair of leaflets, or rarely 3 pair on the lower part of the stem; leaflets short-petioled, opposite or alternate, linear or ensiform, acute, smooth; on the upper part of the stem, about 3 inches long; on the lower part, about half the length. Pe tioles wide, deeply channelled on the upper side, and keeled on the lower. Stipules semisagittate, taperpointed, joined to the base of the footstalk; on the lower part of the stem ovate, and on the upper part lanceolate. Racemes short, axillary, the flowers all leaning to one side. Peduncles very long and slender, G 2 
a little flattened, slightly furrowed. Pedicles scarcely as long as the calyx, slender, all bent to one side. Calyx smooth, tubular, blunt at the base; limb 5 -toothed; teeth subulate, unequal; the upper ones shortest and deepest. Corolla papilionaceous, white, slightly tinged with rose; vexillum obovate, blunt, slightly emarginate; ala, or wings, about the length of the vexillum; spoon-shaped, eared on the inside, unguiculate; keel shorter than the wings, of a greenish white, curved upwards. Stamens 10, diadelphous, 9 connected into a tube, the other distinct. Pod flat, many-seeded, terminated with a green pointed style, and fringed stigma.

Our drawing of this handsome plant was taken at the Nursery of Messrs. Whitley, Brames, and Milne, at Fulham; we also received specimens of it from Mr. Knight, of the King's Road. It thrives well in a rich light soil; and ${ }_{r}$ when grown strong, attains the height of 2 feet, flowering in May and June, and ripening its seeds in July, which should be sown as soon as ripe; they will then make flowering plants for the next season, if properly treated. They may either be sown in pots, or in the open ground; if in the latter, it should be a sheltered situation, and free from weeds; they may also be increased, but sparingly, by dividing at the root.

1. Calyx. 2. Vexillum. 3. Alæ, or Wings. 4. Carina, or Keel. 5. Stamens, with the style exserted just above them. 6. The single distinct Stamen. 7. The other 9 connected into one piece about half way up. 8. The young Seed-pod, terminated with its Style. 


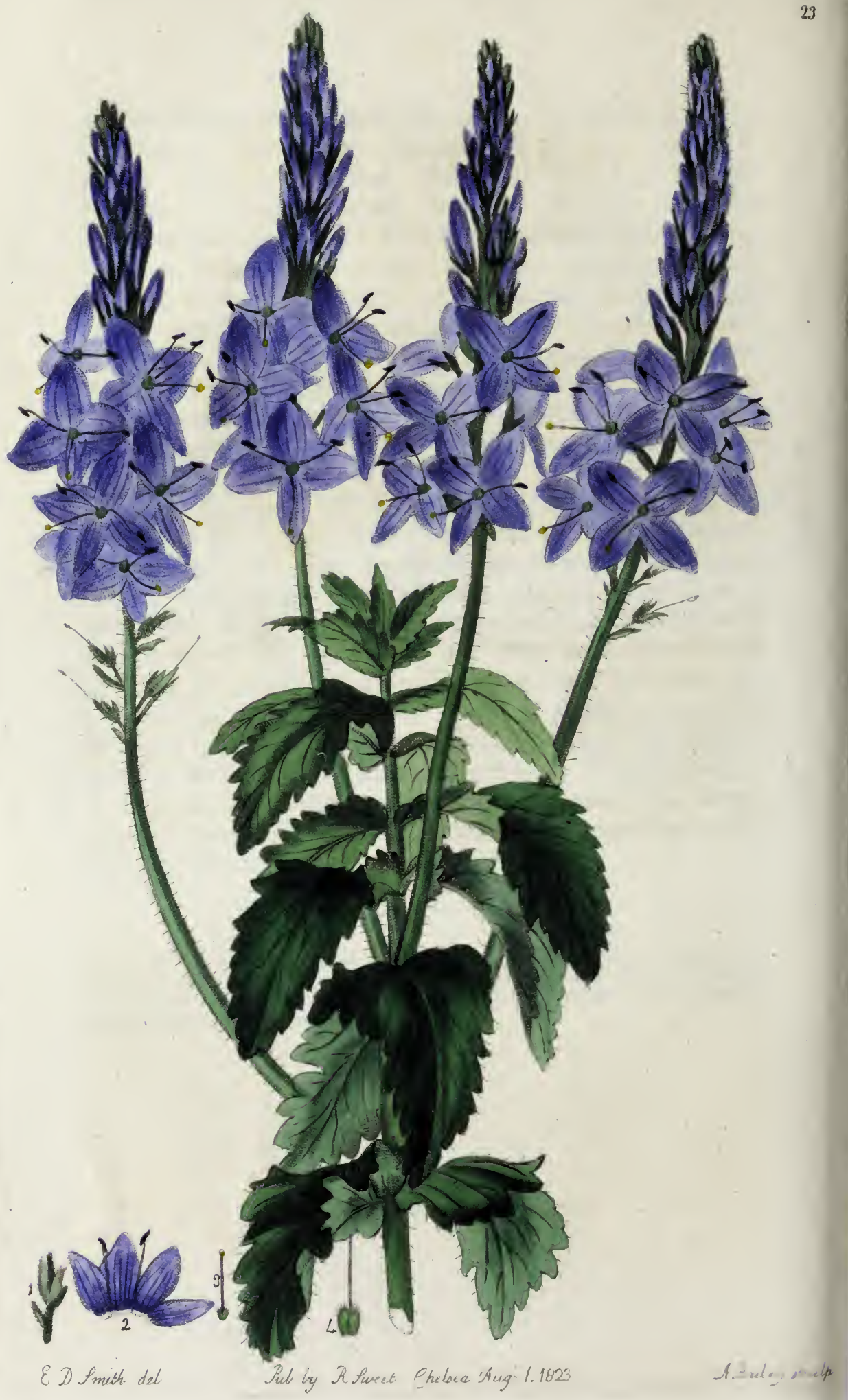




\title{
VERONICA latifolia.
}

\author{
Broad-leaved Speedwell.
}

Natural Order. Scrophularina. Brown prodr. 433.

Sect. I. Stamina duo antherifera, Capsula bilocularis.

VERONICA. Calyx 4-partitus, raro 5-partitus. Corolla subrotata. Tubus calyce brevior. Limbus 4-partitus, inæqualis, lobis indivisis. Stamina 2, antherifera, sterilia nulla. Capsula valvis medio septiferis, v. bipartibilis.

Herbæ vel Frutices, Folia opposita, quandoque verticillata v. alterna, scepe dentata $v$. incisa. Inflorescentia varia. Calyces ebracteati. Brown prodr. 434.

V. latifolia, racemis lateralibus longissimis, foliis cordato-ovatis sessilibus rugosis obtuse serratis, caule erecto, segmentis calycinis quinis.

Veronica latifolia. Willden. sp. pl. 1. p. 71. Pers. syn. 1. p. 12. Hort. Kew. ed. 2. v. 1. p. 33. Ram. et Schult. 1. p. 111.

Veronica pseudo-chamædrys. Jacq. aust. 1.p. 37. t. 60.

Veronica Teucrium. Roth neue Beytrage. p.69. Pers. syn. 1. Corrigenda et Addenda.

Root perennial, tufted. Stems erect, simple, thickly clothed with a dense woolly pubescence, from 18 inches to 2 feet high. Leaves opposite, cordately ovate, sessile, clasping the stem, rugose or wrinkled, bluntish, and bluntly serrated, hairy on both sides, of a dark green colour ; upper leaves narrower and more pointed. Racemes lateral, very long, many flowered, generally 4 on each stalk. Flower-stallss cylindrical, villous. Bractes subulate; lower ones about the length of the peduncle; upper ones about half the length. Calyx deeply 5-cleft, segments unequal, taper-pointed, back 
ones nearly double the length of the middle ones; front one very short and small. Corolla 4-cleft, of a bright blue colour, segments unequal; the upper one largest, cordately ovate; middle ones rather less; lower one narrowest, and more pointed. Stamens 2 ; filaments inserted in the mouth of the corolla, scarcely as long as the segments; anthers incumbent. Capsule nearly orbicular, emarginate, the septum passing down through the middle. Style smooth, about the length, or a little longer than the stamens. Stigma capitate.

The present ornamental plant is a native of Austria ; and succeeds well in our flower borders in the open ground, flowering from May to July; we think it one of the handsomest species of the genus; and it will thrive in any soil, or situation; but the richer the soil is, the stronger it will grow, and the flowers will be more numerous; though it will succeed very well in a small pot, if it be well supplied with water. It is readily increased by dividing at the root; or by seeds, which ripen plentifully. Our drawing was taken at the Nursery of Mr. Colvill, in June last.

1. Calyx split open, to show the 5 segments, and the bracte at the base of the footstalk. 2. Corolla split open, showing the insertion of the 2 stamens. 3. Germen, Style, and capitate Stigma. 4. Capsule, all natural size. 


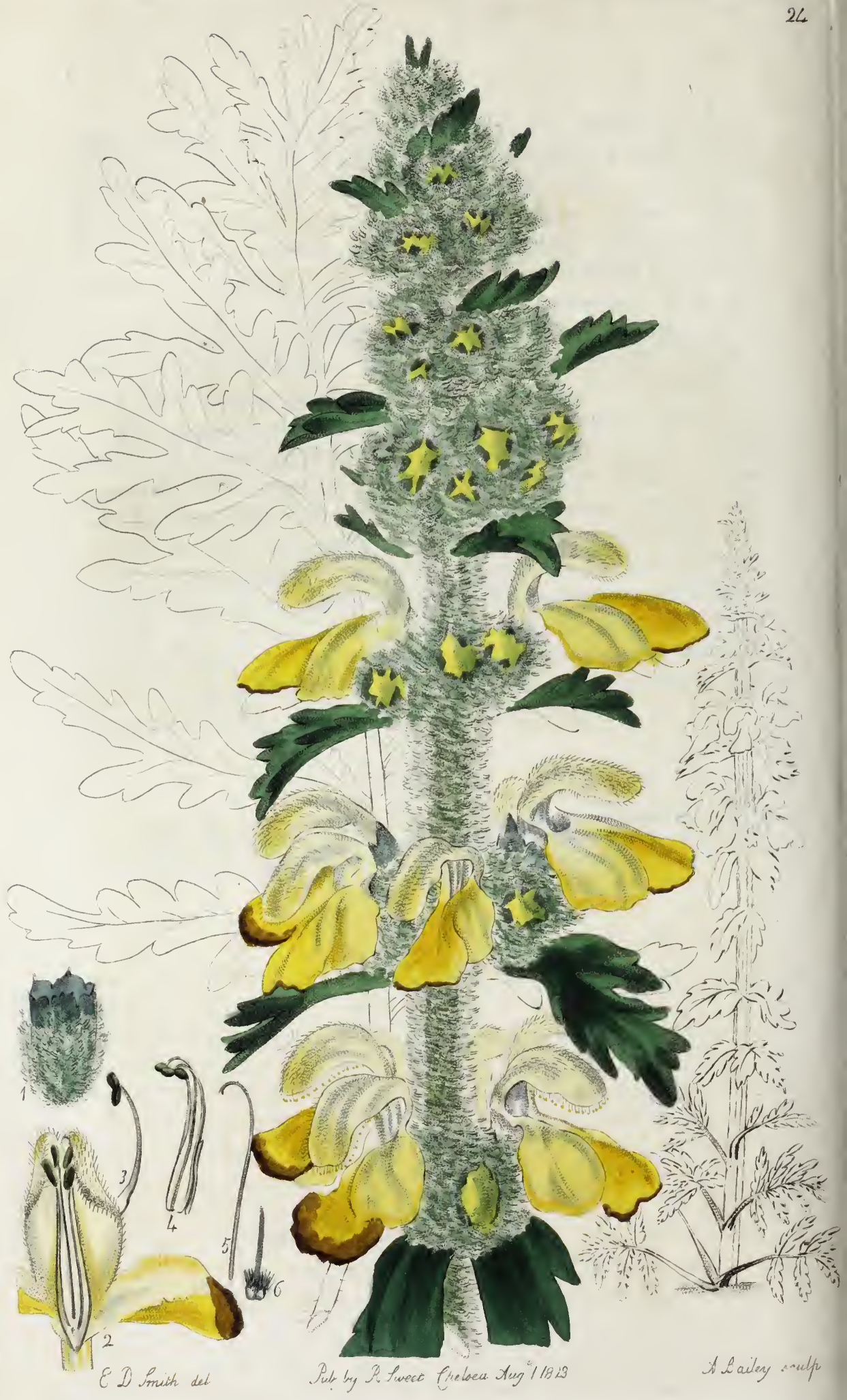




\title{
24
}

\section{PHLOMIS laciniata.}

\author{
Jagged-leaved Phlomis.
}

Natural Order. Labiate. Brown prodr. 499.

Sect. II. Stamina 4-fertilia, antheris omnium v. duorum completis.

A. Calyx regularis 5-fidus v. 5-10-dentatus.

PHLOMIS. Calyx 5-gonus, 5-dentatus. Corolla galea incumbens, carinato-compressa, barbata, emarginata v. incisa ; labium inferius proportionatum; lobo medio majore. Stigma labio superiore breviore. Brown Hort. Kew. ed.2. v. 3. p. 406.

P. laciniata, foliis alternatim pinnatis ; foliolis laciniatis, calycibus lanatis. Willden. sp. pl. 3. p. 120. Pers. syn.2. p. 126. Hort. Kew. ed. 2. v. 3. p. 408.

Root perennial, herbaceous. Stem erect, thickly clothed with a woolly pubescence, about 3 feet high. Leaves near the root, petiolate, alternately pinnate, downy; leaflets lanceolate, more or less laciniate; segments unequal, obtuse, sometimes toothed; stemleaves sessile, pinnatifid or laciniate, smooth and shining on the upper side, and downy on the lower; segments obtuse, unequally toothed with blunt teeth. Flowers whorled in a long spike. Bractes subulate, clothed with long woolly hairs. Calyx tubular, narrowest at the base, 5 -sided, angles terminated with 5 short subulate teeth, densely clothed inside and out with long shaggy wool. Corolla tubular, 2-lipped, woolly; helmet keeled, compressed, emarginate, densely fringed, of a pale sulphur colour; lower lip very broad, keeled, 3-lobed; upper lobe undulate, of a deep yellow, edged with brown; side-lobes flat, of a 
pale yellow. Stamens 4, ascending, the 2 uppermost rather longest, inserted in the mouth of the corolla, and joined at the base; the 2 lower ones shorter, inserted in the tube below the mouth; filaments hairy; anthers incumbent. Seeds 4, smooth at the base, points bearded. Style smooth, about the length of the stamens. Stigma unequally forked.

The present rare and handsome species is a native of the Levant; and, although it has been in our gardens ever since the year 1731, it is now seldom to be met with. For the opportunity of giving this figure, we are obliged to Messrs.Whitley, Brames, and Milne, at whose Nursery, at Fulham, it flowered luxuriantly, this Summer, the plant having attained the height of 3 feet. We suspect one reason of its present scarcity to be, its suffering from too much moisture in Winter; it is, therefore, requisite to keep some plants of it in pots, that they might be protected under frames in moist or very cold weather. The best method of increasing it is from seeds, which will ripen plentifully, if some pollen be rubbed on the stigmas when in full bloom; as soon as gathered, they should be sown in pots, and preserved under a frame in Winter, and they will make flowering plants for the next Summer.

1. Calyx. 2. Corolla split open, showing the insertion of the stamens. 3. Stamen detached. 4. The 2 upper Stamens joined together, about half way their length; the upper parts distinct. 5. Style and Stigma. 6. The 4-bearded Seeds. 


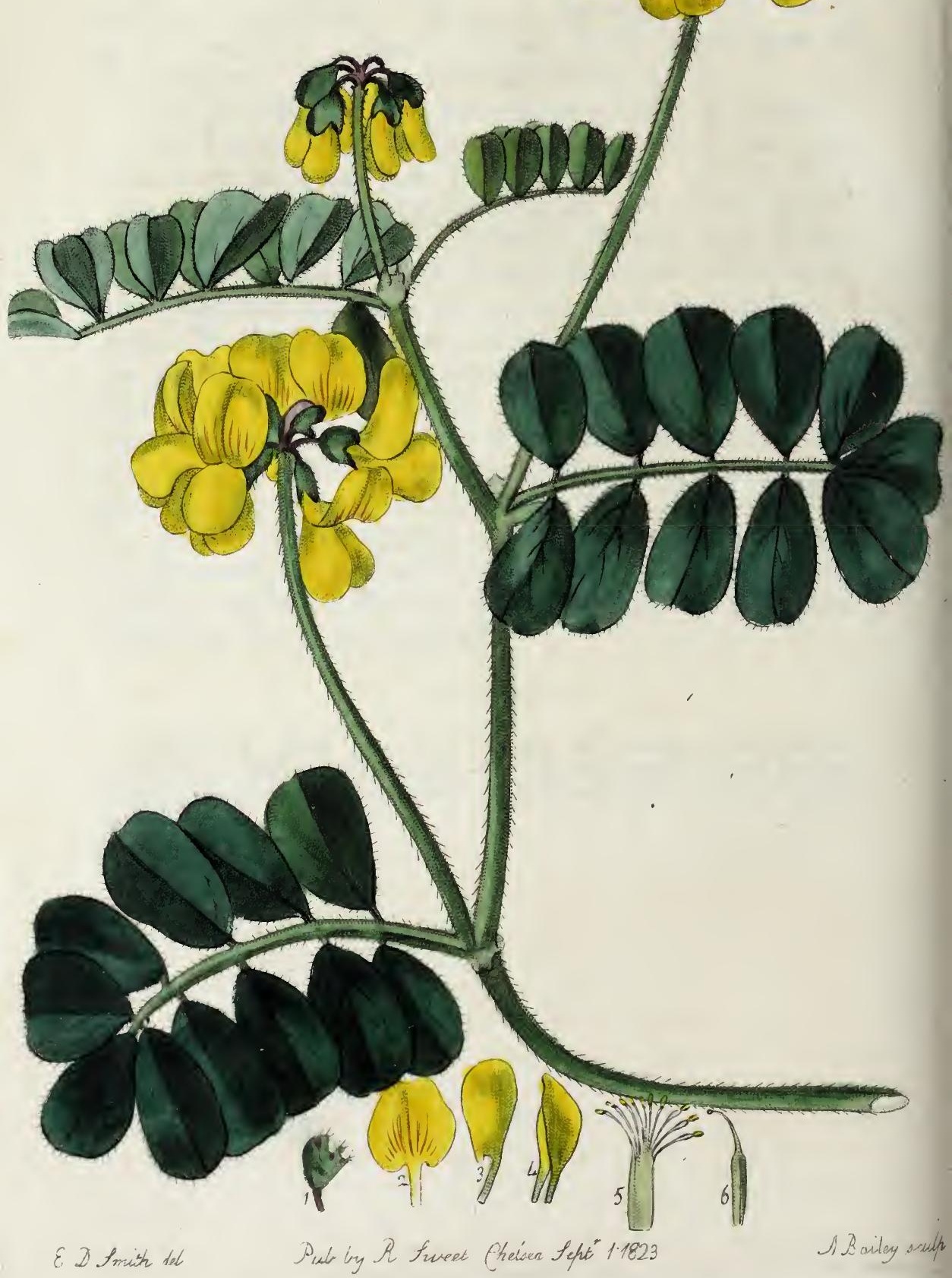




\title{
CORONILLA iberica.
}

\author{
Iberian Coronilla.
}

Natural Order. Leguminosa. Juss. gen. 345.

Div. VIII. (PAPILIONACEA.) Corolla irregularis papilionacea. Stamina decem diadelpha. Legumen articulatum articulis monospermis. Juss. gen. 361.

CORONILLA. Calyx 2-labiatus; suprà 2-dentatus dentibus junctis : infrà 3-dentatus. Vexillum vix alis longius. Lomentum teres, articulatum, rectum.

Herbæ aut Suffrutices; folia impari-pinnata, stipulis à petiolo distinctis, pedunculi axillares et terminales, umbellatim multiflori; legumen in pluribus 2-valve sub 1-loculare vix articulatum, in Coronilla T. subcylindricum seminibus oblongis, in Securidaca T. latius compresso-planum apice subulatum seminibus subquadratis, tenue subulatum seminibus cylindricis in Emero T. cujus praterià caulis frutescens et petala unguiculata et unguis vexilli basi 2-callis. Juss. gen. 361.'

C. iberica, herbacea procumbens, foliolis undenis cuneatoobcordatis sericeo-pubescentibus, stipulis cuneatis ciliatis, umbellis 6-8-floris.

Coronilla iberica. Marsch. Bieb. taur. cauc. 1. 171. 3. 479. Link enum. 2. p. 244 . Steud. nomen. 228.

Root perennial. Stems numerous, prostrate, spreading round in all directions, slightly angular, pubescent. Leaves pinnate; leaflets generally 11, cuneate or obcordate, covered on both sides with a silky pubescence, margins fringed. Petioles channelled on the upper side, and convex on the lower. Stipules short, cuneate, fringed. Peduncles cylindrical, pubescent, bearing umbels of from 6 to 8 flowers. Involucre of several very small pointed teeth. Pedicles scarcely 
as long as the calyx, recurved. Calyx 2-lipped; upper lip keeled, composed of 2 flat teeth joined together, fringed at the point with numerous long white hairs; lower lip toothed with 3 sharp pointed teeth, also fringed. Corolla papilionaceous, of a bright yellow colour; vexillum about the length of the wings, unguiculate, keeled, emarginate; ala or wings obovate, unguiculate, eared on one side; keel about the length of the wings, or scarcely as long, bifid at the base, point acute, curved inwards. Stamens 10 , scarcely diadelphous, the back stamen being joined to the others more than half way up; filaments all distinct at the points; anthers incumbent. Style falcate, gradually tapering upwards. Stigma capitate.

For the opportunity of giving a figure of this beautiful plant, we are indebted to Mr. Anderson, Curator of the Garden belonging to the Apothecaries' Company, at Chelsea, where it is cultivated in the open ground, and spreads round to some distance, making a fine appearance with its numerous golden yellow flowers; it differs from the others of the genus, by its stamens being all connected at the base.

Being a native of Iberia, it is likely to succeed well in the open borders; but it will be well to keep some plants of it in pots, that they may be protected in a frame in Winter, as it may probably suffer from too much moisture. It is readily increased by seeds, which ripen freely.

1. Calyx. 2. Vexillum. 3. One of the ala, or wings. 4. Keel. 5. The 10 stamens joined at the base, the back one parted from the others about half way down. 6. Germen, terminated with the Style, and small capitate Stigma. 



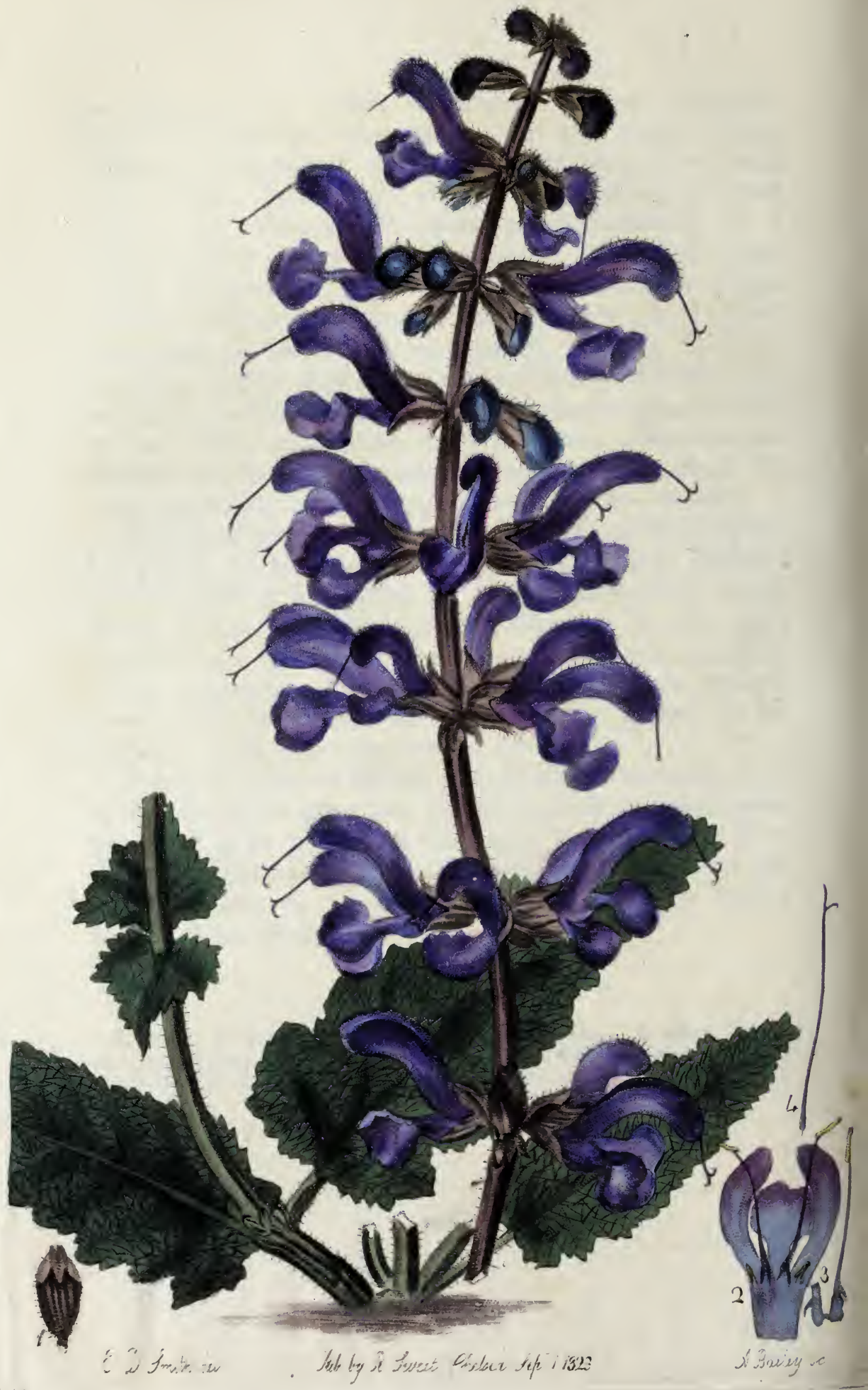




\section{6}

\section{SALVIA Tenorii.}

\section{T'enore's Sage.}

Nalural Order. La biate. Brown prodr. 499.

Sect. I. Stamina 2 fertilia; v. dum 4 fertilia. Antheræ omnium dimidiatæ.

SALVIA. Calyx subcampanulatus, bilabiatus, labio superiore 3-dentato, inferiore bifido. Corolla ringens. Filamenta duo fertilia bifida, lobo altero adscendenti antherâ dimidiatâ, altero sterili. Folia rugosa. Flores verticillato-racemosi. Brown prodr. 500.

S. Tenorii, foliis oblongis subsinuatis inæqualiter crenatis rugosis reticulato-venosis; summis amplexicaulibus acutis, verticillis subnudis, corollis galea hirsuta falcata, calycibus sulcatis.

Salvia Tenorii. Spreng. pug. 1. n. 3. Rcem. et Schult. syst. 1. 242. Link enum. 1. p. 14. Steud. nomen. p. 729. Salvia Barrelieri. Tenore. Sichrank. Hort. monac. 1. t. 5.

Root perennial. Stems from 1 to 2 feet high, not much branched; branches bluntly quadrangular, thickly clothed with unequal spreading hairs. Leaves near the root petiolate, oblong, slightly jagged, unequally crenate, bluntly pointed, very rugged and uneven, reticulately veined, hairy on both sides; upper leaves clasping the stem, or sometimes with very short footstalks, cordate, acute, more deeply jagged. Petioles flat on the upper side, and convex on the lower, hairy, as are the peduncles and calyx. Flowers growing in whorls, about six in each, of a beautiful dark blue, tinged with purple. Bractes small, cordate, taper-pointed, fringed. Peduncles short and slender, 
about half the length of the calyx. Calyx campanulate, hispid, deeply furrowed with numerous channels, 2-lipped; upper lip terminated in 3 short pointed teeth; lower lip bifid. Corolla ringent, hairy; helmet narrow, and very much falcate; lower lip 3-lobed, terminal lobe cucullate, crenate, side ones small and narrow. Stamens 2, fertile, on short stems; filaments ascending; anthers linear, incumbent; sterile stamens 2, gland-like, on a short footstalk. Seeds 4, smooth, of a dark brown colour. Style long and slender, terminated with an unequal bifid stigma.

This handsome plant was raised last year at the Nursery of Mr. Colvill, from seed received from Dr. Fischer, then at the Botanic Garden at Gorenki, under the name of $\mathrm{S}$. dumetorum; but we have no doubt but it is the species for which we have given it, and it is cultivated by Mr. Anderson as such. It makes a fine show in the flower borders, being covered with beautiful blue flowers in May and June. Our plants grew nearly 2 feet high; perhaps when it gets stronger, it will attain a greater height; it thrives well in the common garden soil, and would succeed very well in rock-work. Seeds of it ripen freely, so that any quantity of them may soon be raised.

1. Calyx. 2. Corolla split open, to show the insertion of the stamens. 3. Stamens detached from the corolla. 4. Style and unequal divided Stigma. 


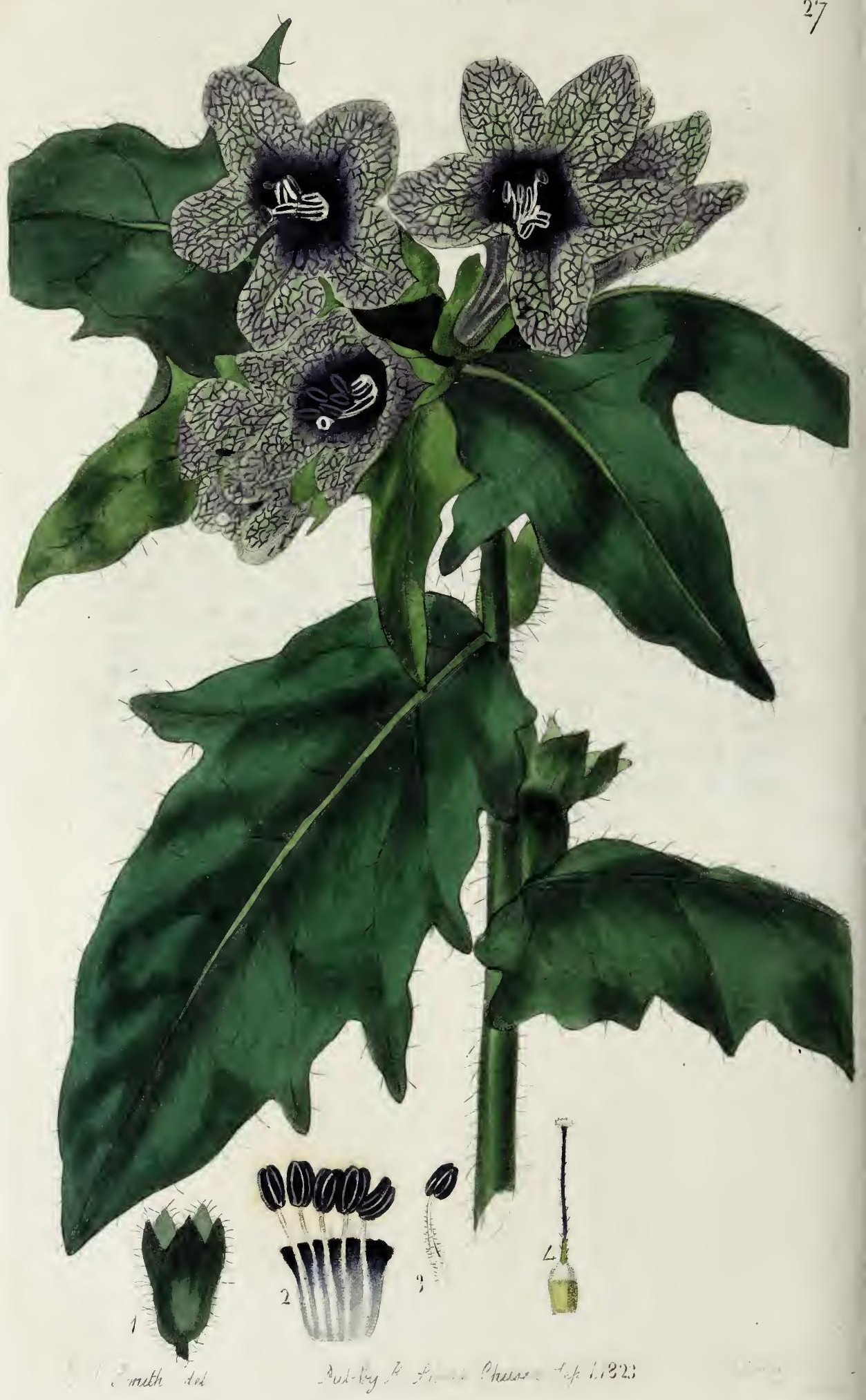




\title{
HYOSCY A MUS agrestis.
}

\author{
Hungarian field Henbane.
}

Natural Order. Solaned. Juss. gen. 124. HYOSCYAMUS. Supra fol. 12.

H. agrestis, foliis amplexicaulibus angulato-dentatis glabriusculis, floribus sub-sessilibus, corollis reticulato-venosis, calycibus angulatis, caule villoso ramoso.

Hyoscyamus agrestis. Roem. et Schult. syst. 4. 308. Link enum. 1. p. 177.

Annual. Stem erect, branching, from a foot to 18 inches in height; branches spreading, thickly clothed with long villous hairs. Leaves clasping the stem, ovate, acute, angular, or toothed with large pointed teeth, smoothish, nerves villous underneath. Flowers all leaning to one side, nearly sessile. Peduncles very short, longest on the lowermost flowers, villous. Calyx tubular, 5-toothed, inflated, angular, thickly clothed with long villous hairs; mouth spreading. Corolla tubular, mouth spreading, ringent, 5 -cleft, of a brownish yellow, reticulately veined with violetcoloured veins, the lower part of a dark-brownish purple; segments unequal, obtuse. Stamens 5, inserted in the tube; filaments densely clothed at the base with rigid spreading hairs, the upper part smooth and naked; anthers incumbent. Germen smooth and shining. Style hairy, about the length of the stamens. Stigma capitate, fimbriate. 
We first observed plants of this species, about seven years back, at the Nursery of Messrs. Whitley and Co. at Fulham; where it was raised from seeds given them by a friend, who collected them on the Carpathian Mountains; it is nearly related to our British species H. niger, but differs in that being biennial; the present is annual. H. pallidas is also allied to it, but its flowers are of a pale yellow, and not netted. It only requires to be sown in the open ground; the plants when come up, must be thinned out, so as to be about 6 inches apart, or else they will be drawn up by being too close together, and the plants will not be so handsome, or flower so well. If the seeds are sown in Autumn, it will bloom early in Spring; if sown in February, they will flower later; some may be sown as late as May or June, to flower late in Autumn; like other annuals, it is a good plan to sow them at different seasons, so as to have a good succession of flowers.

Drawn at the Nursery of Mr. Colvill, where the plants grew about 18 inches high, and produced plenty of seeds.

1. Calyx. 2. Corolla split open, to show the insertion of the stamens. 3. Stamen detached, showing the hairy filament. 4. Germen, Style, and fringed capitate Stigma. 



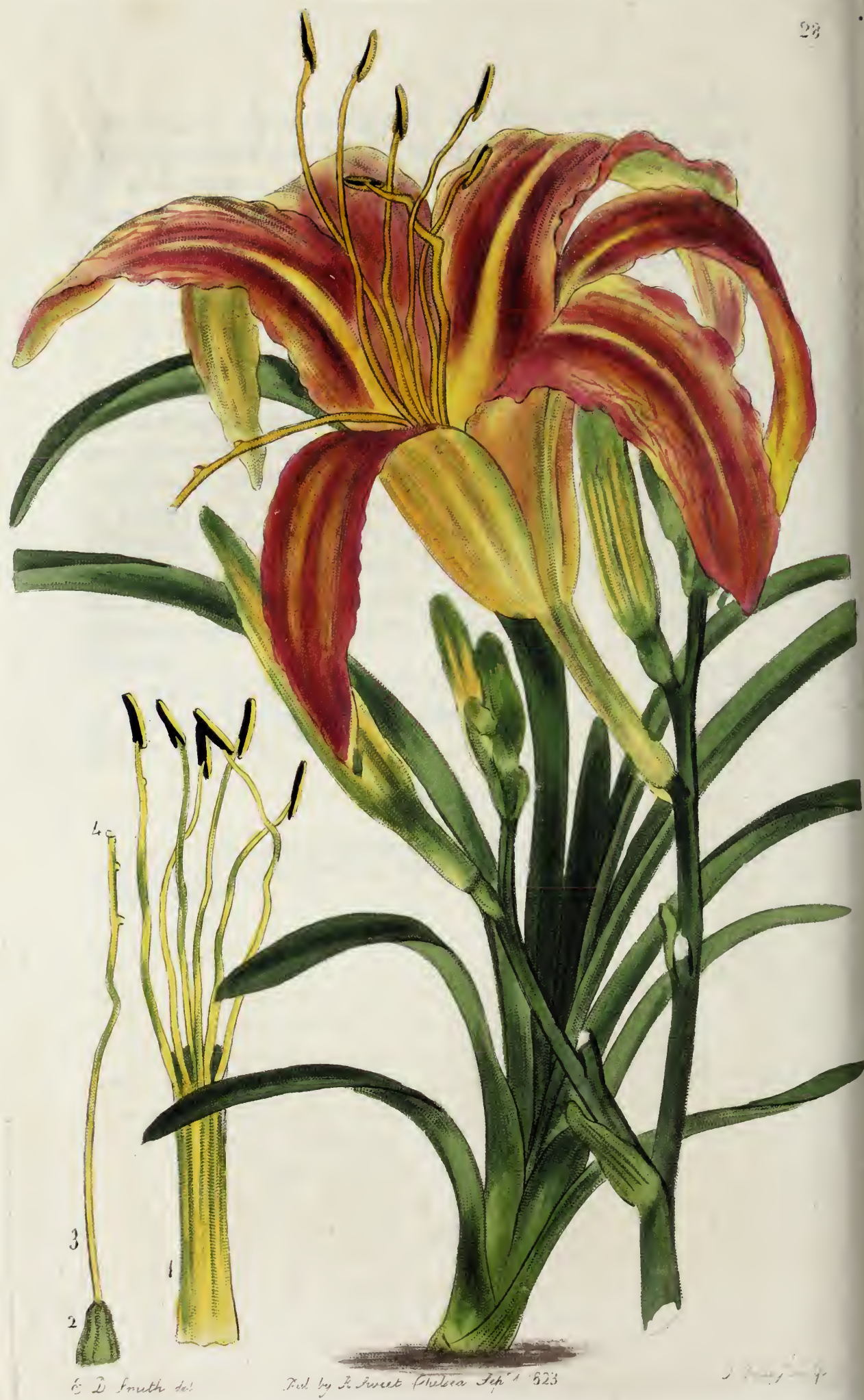




\title{
28
}

\section{HEMEROCALLIS disticha.}

\author{
Fan-like Day-Lily.
}

Natural Order. Hemerocallideas. Brown prodr. 295.

HEMEROCALLIS. Perianthium campanulatum; tubo cylindrico. Stamina 6, declinata. Stigma parvulum, simplex, villosulum.

Herbæ perennes; rhizoma fibris fasciculatis carnosis crassis nunc fusiformi-protuberantibus ; folia radicalia plura-numerosa a plano obversa bifaria, ambientiave, lorato-attenuata, ab inferius convoluto-equitantibus canaliculato-explicantia, nunc petiolata lamina nervoso-costata; caulis teres, bractea vel spatha sterili nunc folio stipatus, simplex; racemus pauci-multiflorus, corymbi-vel thyrsiformis, vel nunc spicatim effusus; pedicelli ramiformes stricti, gracilisve flexilis; flores majusculi, speciosi. Plurimum Lili, multum Agapanthi habet. Ker Botan. magaz. 1433.

H. disticha, foliis linearibus carinatis distichis, perianthium laciniis lanceolatis undulatis acutis patentibus reflexis; tribus interioribus latioribus, nervisque petalorum exterioribus ramosus.

Hemerocallis disticha. Donn Cant. ed. 6.93. Botan. magaz. 1433. Specie. enumer. Hort. sub. lond. p. 67. Hemerocallis fulva. Thumb.jap. 142. excl. syn. Linn.

Perennial, producing numerous suckers from the base. Leaves distichous, or fan-like, linear, bluntly keeled on the lower side, and deeply channelled on the upper, elegantly striated, smooth and glossy; when full grown, nearly a yard in length. Flower-stem proceeding from the side of the shoot, much shorter than the leaves, (in our specimen,) about 1 foot 9 inches in height, forked at the point, slightly angular upwards, a little twisted, and slightly covered with a whitish powder, which comes off as soon as touched; from the stem is produced 3 bracte like leaves or sterile 
spathes, from 2 to 3 inches in length, sheathing the stem, their margins involute. Scapes forked. $\boldsymbol{R} a$ cemes 2, (in our specimen,) each producing 6 flowers, 1 or 2 opening at the same time. Bracte short, at the base of each flower, cordate or ovate, pointed, membranaceous, sheathing the stem; upper ones shortest, and broadest. Peduncle very short, decurrent down the stem. Perianthium campanulate, tubular; tube about 1 inch and a half in length, cylindrical, pale yellow; segments 6 , lanceolate, undulate, acute, spreading, about 3 inches and a half long, reflexed about half their length, of a light brown orange colour; inner petals broadest. Stamens 6, inserted in the mouth of the tube; filaments long, declining, irregularly bent, with here and there a protuberance on them. Anthers incumbent, slightly attached to the filament. Germen smooth, obsoletely 3 -sided. Style about the length of the stamens, with some irregular protuberances towards the point. Stigma simple, slightly bearded.

Our drawing of this beautiful plant was taken at the Nursery of Messrs. Allen and Co., King's Road, where it produced 2 scapes of flowers; one, after the other was over. It is seldom to be met with in flower in our collections, and may therefore be considered a great rarity. We have been acquainted with it for several years, but never saw it flower before; perhaps the reason is, that we have, generally, seen it cultivated in the open ground; the present subject was grown in a pot, by which means it grew weaker, and, perhaps, that occasioned its flowering.

It is a native of China, but grows freely in the open ground, in the common garden soil; and propagates readily from the suckers, which it produces in abundance.

1. The Tube split open, showing the 6 stamens inserted in its mouth. 2. Germen. 3. Style, showing some protuberances towards the point. 4. The bearded Stigma. 
11

, 


\section{PHLOX triflora.}

Pubescent-stemmed Lychnidea.

Natural Order. Polemonidea. Juss. gen. 136.

PHLOX. Calyx 5-fidus aut 5-partitus connivens. Corolla tubulosa hypocrateriformis, tubo longo, limbo plano 5-partito. Stamina 5 inæqualia; antheris sagittatis. Stigma trifidum. Capsula 3-locularis, 1-sperma.

Herbæ; folia opposita simplicia, floralia interdum alterna; flores subcorymbosi terminales. Habitus Saponaria, sed flos 1-petalus. Juss. gen. loc. cit.

P. triflora, caulibus erectis subpubescentibus, foliis lanceolatis glabris, corymborum ramis subtrifloris, calycinis dentibus linearibus. Michaux. Flor. Amer. 1. p. 143.

Phlox triflora. Pers. syn. 1. p. 186 . Hort. sub. lond. p. 36. Colv. catal. ed. 2. p. 40. col. 1.

Phlox carnea. Botan. magaz. 2155.

$\boldsymbol{R}$ oot perennial. Stems branching, nearly erect, a little flexuose, from a foot to 18 inches high, thickly clothed with a dense woolly pubescence, upper part obsoletely quadrangular; branches spreading, each crowned with a corymbus of flowers. Leaves shortpetioled, entire, lanceolate, acute, broad at the base, smooth, and dotted all over with innumerable minute dots; lower ones opposite, those near the flowers sometimes alternate. Flowers in a loose spreading corymbus, of a pale lilac colour; branches of the corymbus mostly 3 -flowered. Peduncles smooth, seldom as long as the calyx. Calyx deeply 5-cleft, segments linear, keeled, and taper-pointed, all joined by a thin membrane at the base. Corolla tubular; 
tube about twice the length of the calyx ; limb 5-parted, segments roundly obcordate, slightly undulate, at last reflexed. Stamens 5, unequal, inserted in the tube, one just below the mouth, and projecting a little beyond it, 2 a little lower down, and the other 2 more than one third of the way down. Filaments very short. Anlhers sagittate. Pollen yellow. Germen smooth, of a dark green. Style smooth, filiform. Stigma trifid, segments erect, or slightly spreading, obtuse.

Our drawing of this beautiful species was taken at the Nursery of Mr. Colvill, where it continues to flower from July to October, if the weather continues mild; like most of the species of this genus, it is a native of North America, and contributes greatly to enliven our flower borders, the latter part of Summer. It succeeds well in the open ground, in the common garden soil, growing to the height of a foot or 18 inches, according to the strength of the plant, or richness of the soil. Cuttings of it planted under hand-glasses, strike root readily; when rooted, they may either be potted, or planted in the ground; the sooner in Spring the cuttings are put in, the stronger the plants will be; and if planted early, many of them will flower the same season.

1. Calyx. 2. Corolla, with its tube split open, to show the insertion of the stamens. 3. Stamen detached. 4. Style, terminated with 3 Stigmas. 



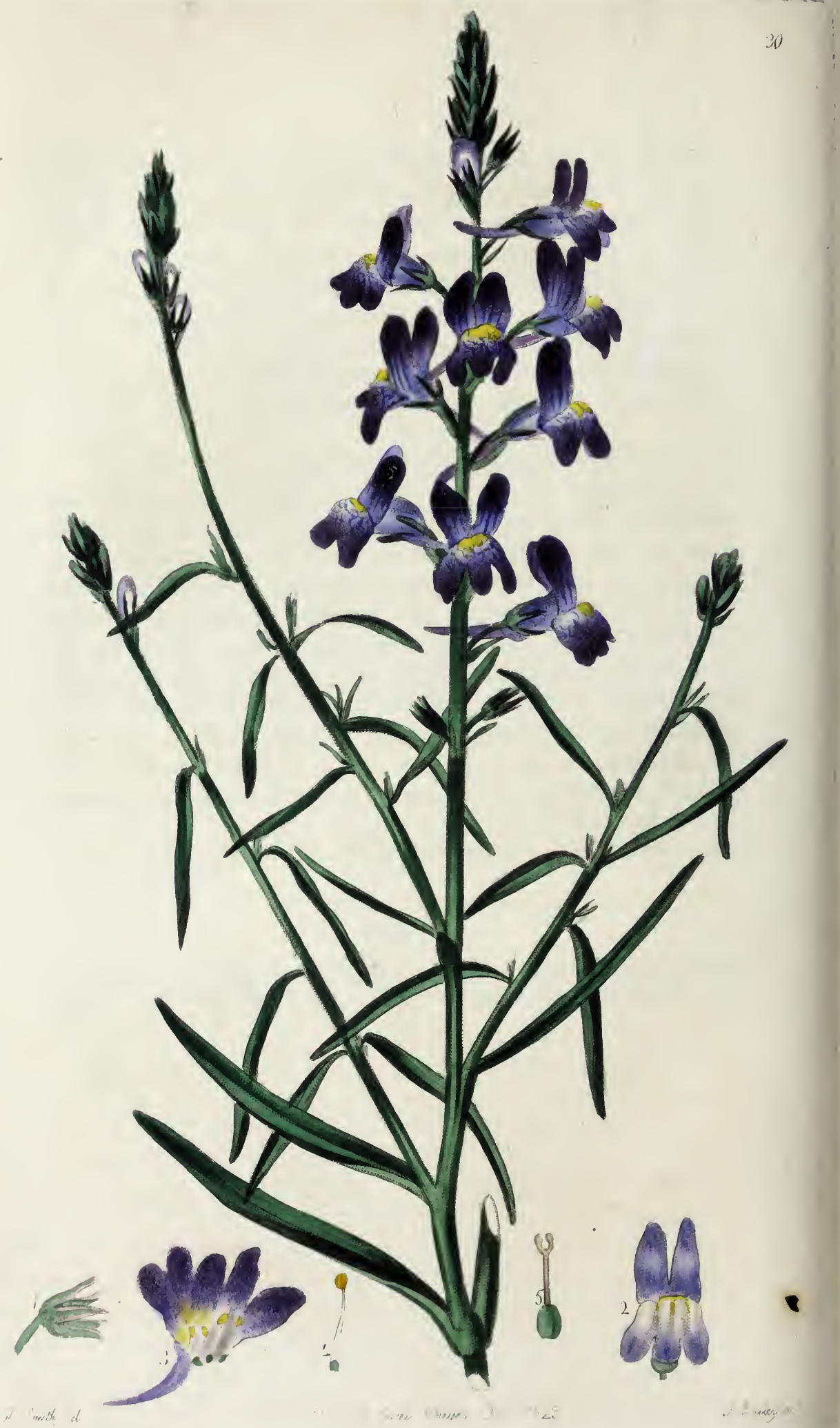




\title{
LINARIA bipartita.
}

\author{
Cloven-flowered T'oad-flax.
}

Natural Order. Scrophularina. Brown prodr. 433.

Sect. II. Stamina 4 antherifera.

LINARIA. Calyx 5-partitus. Corolla basi calcarata; faux palato clausa. Capsula ventricosa, bilocularis, valvata v. dentata; dissepimento membranaceo, medio seminifero.

Folia sapius alterna, in quibusdam inferiora opposita aut verticillata; flores axillares, aut sapius bracteati spicati terminales. Species quadam palato destituta; qucedam interdum, facundatione hybrida, corollis onusta regularibus (Peloria L.) 5-andris, basi 5-calcaratis, limbo 5-lobis, interea non fructifera, sed taleis propaganda. Juss. ğen. 120.

L. bipartita, foliis lineari-lanceolatis; inferioribus oppositis : superioribus alternis, racemis laxis, galea erecta bipartita.

Linaria bipartita. Willd. enum. 2.640. Link enum. 2. 136. Hort. sub. lond. p. 141.

Antirrhinum bipartitum. Vent. hort. cels. t. 82. Pers. syn. 2. p. 155.

Antirrhinum speciosum. Donn. hort. cant. ed. 7. p. 178.

Root annual. Stem erect, branching; branches erect, nearly cylindrical, smooth, and glossy. Leaves linearly lanceolate, acute, concave, slightly pubescent, glaucous ; lower ones opposite ; upper ones alternate. Racemes long, erect, flowers rather distant from each other. Bractes cordately lanceolate, taper-pointed, with red margins. Pedicles slender, longer than the bractes. Calyx 5-parted nearly to the base; segments lanceolate, acute, keeled; margins red and transparent. Corolla tapering into a long sharp spur at the base, mouth closed; helmet erect, 2-parted, lobes ligulate, 
obtuse; lower lip 3-lobed, the middle lobe smallest, side ones rounded and spreading. Flowers varying from a bright blue purple to a light purple, and variously marked with yellow. Stamens 4, inserted in the base of the corolla, the 2 upper ones shortest; filaments smooth; anthers incumbent. Style smooth, shorter than the stamens. Stigma bifid, points curved inwards towards each other.

A very handsome hardy annual, which requires no particular care, as the seeds may be sown in the open ground, where they are to remain, and only require to be kept clean from weeds; it seldom exceeds a foot in height, but branches a good deal, so that the plants should not grow too close together; the colour of the flowers vary considerably on different plants, some being nearly blue, others more inclining to purple, and some are nearly yellow; if the seeds are sown the latter end of March, or beginning of April, the plants will be more forward and stronger than those that are sown later in the season; and if the weather be not too dry, they will continue to make young shoots, and flower all the Summer.

Drawn at the Nursery of Mr. Colvill. A native of Barbary, and flowers from June to October.

1. Calyx. 2. Front view of the Corolla. 3. The same spread open, to show the insertion of the stamens. 4. Stamen. 5. Germen, Style, and bifid Stigma. 



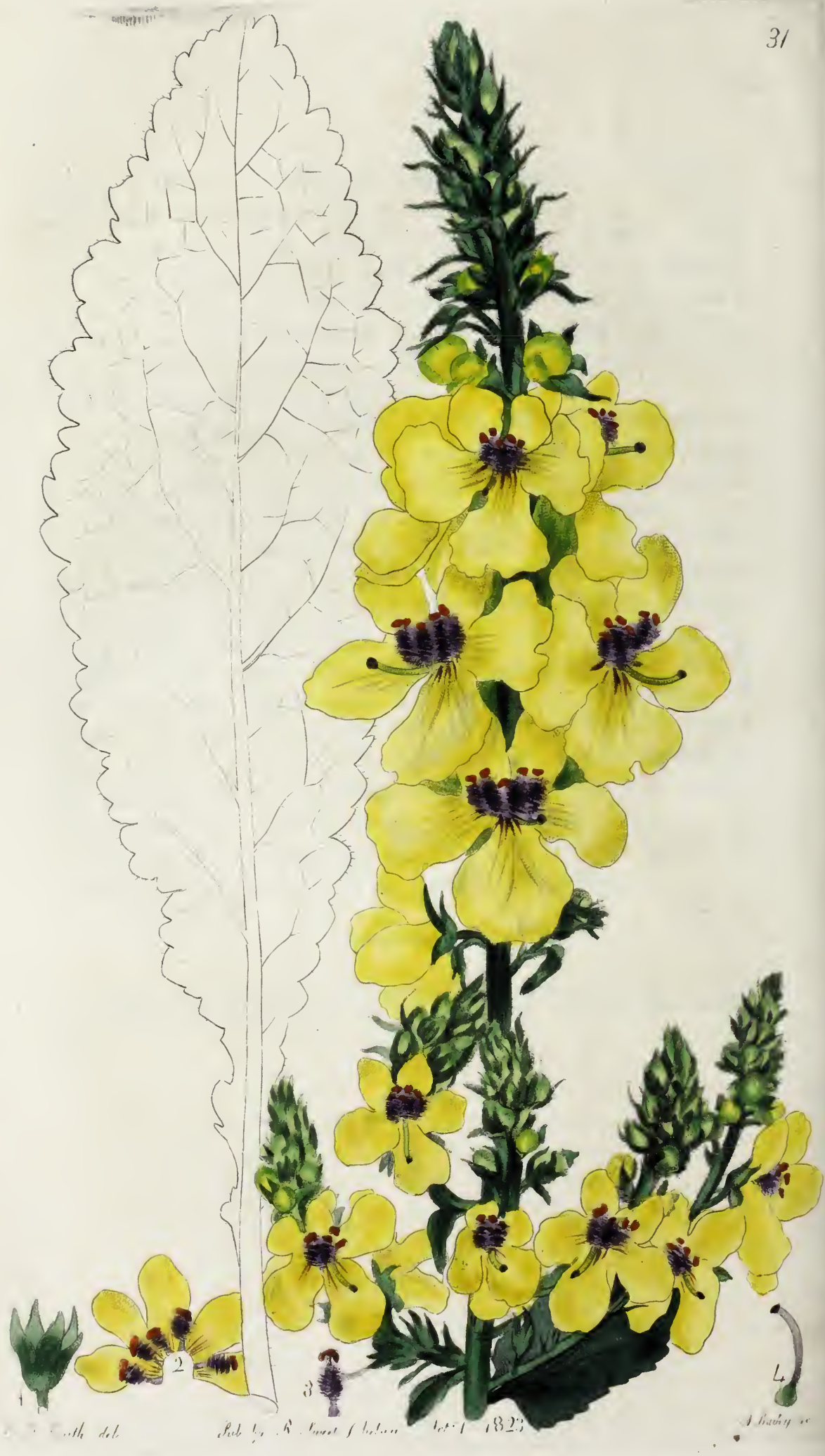




\title{
31
}

\section{VERBASCUM pyramidatum.}

\author{
Pyramidal Mullein.
}

Natural Order. Solanez. Juss. gen. 124.

Sect. I. Pericarpium capsulare.

VERBASCUM. Calyx 5-partitus. Corolla rotata patens 5-loba inæqualis. Stamina 5, inæqualia, filamentis inclinatis barbatis. Stigma 1. Capsula 2-locularis, 2-valvis; valvulis inflexis, polysperma.

Herbæ, pleraque tomentosa ; folia quorumdam decurrentia, quorumdam petiolus appendiculatus; flores Blattariæ T. spicati more Celsice, Verbasci T. spicato-paniculati bracteati, bracteis multifloris. Juss. gen, loc. cit.

V. pyramidatum, foliis nudiusculis ; inferioribus oblongis basi attenuatis: superioribus cordatis acuminatis subsessilibus, racemis paniculatis, floribus sparsis subsolitariis, filamentis omnibus barbatis. Willd. enum. 1. p. 224.

Verbascum pyramidatum. Rom. et Schult. syst. 4. p. 343. Link enum. 1. p. 175. Hort. sub. lond. p. 40.

Biennial. Stem erect, from 5 to 8 feet high, much branched; branches forming a pyramid, lower ones very long, putting out other branches from the bottom; upper ones shorter and simple, all slightly decurrent, furrowed, very downy. Leaves reticulately veined, a little rugged, smooth and shining, scarcely pubescent; lower ones oblong, slender at the base, with a short footstalk, sometimes 18 inches in length, unequally jagged, and toothed with large bluntish teeth; gradually lessening in size up the stem; at length cordate, sessile, acuminate, more or less jagged or toothed. Racemes very long, branched. Flowers scattered, generally solitary, of a light yellow. 
Bracte 1, at the base of each pedicle, lanceolate, taper-pointed, slightly fringed, lower ones a little longer than the calyx, upper ones not so long. Pedicles scarcely as long as the segments of the calyx, very downy. Calyx 5-parted, segments unequal, some ovate, others lanceolate, acute. Corolla rotate, spreading, 5-parted; laciniæ unequal, the 2 upper ones smallest and narrowest; the lower one largest and broadest. Stamens 5, inserted into the base of the corolla, the upper ones shortest; filaments smooth and naked at the base, of an orange colour, upper part densely bearded with violet-coloured villous hairs; anthers reniform; pollen orange-coloured. Style smooth and glossy. Sirgma capitate, villous.

A fine stately biennial, native of Mount Caucasus. Drawn at the Nursery of Mr. Colvill, where it was raised last year from seed sent by Dr. Fischer. In rich soil, it will attain the height of 7 or 8 feet, of a pyramidal form ; and being of strong growth, it should be kept at the back of the flower borders. If the seeds are sown as soon as ripe, the young plants will come up and flower the next season. It appears to the greatest advantage singly, as its pyramidal shape is then better seen. Seeds ripen in abundance, by which any quantity may be raised.

1. Calyx. 2. Corolla spread open, showing the insertion of the stamens at the base, alternating with the segments of the corolla. 3. Stamen detached. 4. Germen, Style, and Stigma. 



\section{NEMOPHILA phacelioides.}

\section{Phacelia-like Nemophila.}

Natural Order. Hydrophyllea. Brown.

NEMOPHILA. Calyx inferus, persistens, 10-fidus; laciniis alternis reflexis. Corolla campanulata, 5-loba; lobis emarginatis. Nectarium foveolæ 10 ad marginem faucis. Stamina brevia. Antherce lunatæ. Capsula unilocularis. Semina 4, unum supra alterum receptaculis duobus parietalibus inserta. (Ovarium uniloculare, placentis duabus parietalibus dispermis, ovulis distantibus. Capsula unilocularis, placentis carnosis, axi longitudinali dorsali affixis, cæterum solutis, seperficie ventrali seminiferis. Brown MSS.) Bot. mag. 2373.

Nemophila phacelioides. Barton fl. americ. 61. Botan. magaz. 2373.

Root biennial ? or, perhaps, annual? Stems succulent, erect, much branched ; branches forked, acutely triangular, occasioned by the decurrent leaves, having 3 flat, or rather convex sides; angles hairy, the hairs recurved. Leaves alternate, pinnatifid, slightly hairy, succulent, of a light green colour; segments oblong, oblique, some bluntish, others acute, finely ciliate; lower ones distant, more or less lobed. Petioles shorter than the leaves, decurrent down the stem, concave on the upper side, and convex on the lower, ciliate, with a fascicle of long white hairs at the base. Peduncles solitary, cylindrical, tapering upwards, 1-flowered, sometimes opposite to the leaf, more frequently on one side, sometimes axillary, or a little above it, smooth, or with here and there a hair scattered on it. Calyx inferior, persistent, 10-cleft; segments oblongly-lanceolate, acute, ciliate, every other 
one several times largest; 5 larger ones erect, or spreading, their margins recurved; 5 smaller, flat, reflexed. Corolla campanulate, densely bearded at the mouth, limb 5-cleft, laciniæ oblong, obtuse, slightly emarginate, veined with numerous branching veins. Nectary 10 small purple hollows, surrounding the mouth of the tube. Stamens 5, scarcely half the length of the corolla; filaments smooth, inserted in the base of the tube; anthers incumbent, sagittate and straight before bursting; afterwards burst on each side, and becoming lunular; pollen white. Germen densely hairy. Style erect, very hairy at the base, and smooth upwards. Stigma bifid, ending in two blunt simple points.

A very beautiful hardy biennial ? or, perhaps, annual? native of North America, and lately introduced by John Walker, Esq. of Southgate, and kindly communicated by him to Mr. Colvill, at whose Nursery our drawing was taken. It belongs to the Natural Order HYDRophyLLEE of Mr. Brown, to which, also, belongs Hydrophyllum, Phacelia, and Ellisia, and a new polyspermous genus, described by Mr. Brown under the name of Eutoca Franklinii; the above genera have been usually referred to Boraginea; an order in which all the true genera belonging to it, bear 4 naked seeds; those above have been referred to it merely on account of the same number of seeds, though contained in a capsule; but, as Mr. Brown observes, Eutoca being polyspermous, cannot certainly belong to Boraginea, but is a true congener of Hydrophyllea; it, therefore, establishes the order, though an anomaly in it.

1. Calyx. 2. One of the laciniæ of the corolla, showing the 2 nectariferous pores, and its bearded base. 3. Stamen inserted in the base of the corolla, showing its crescent sliaped anther. 4. The same just as the flower opens, when the anthers are straight. 5. Germen, Style, and Stigma. 



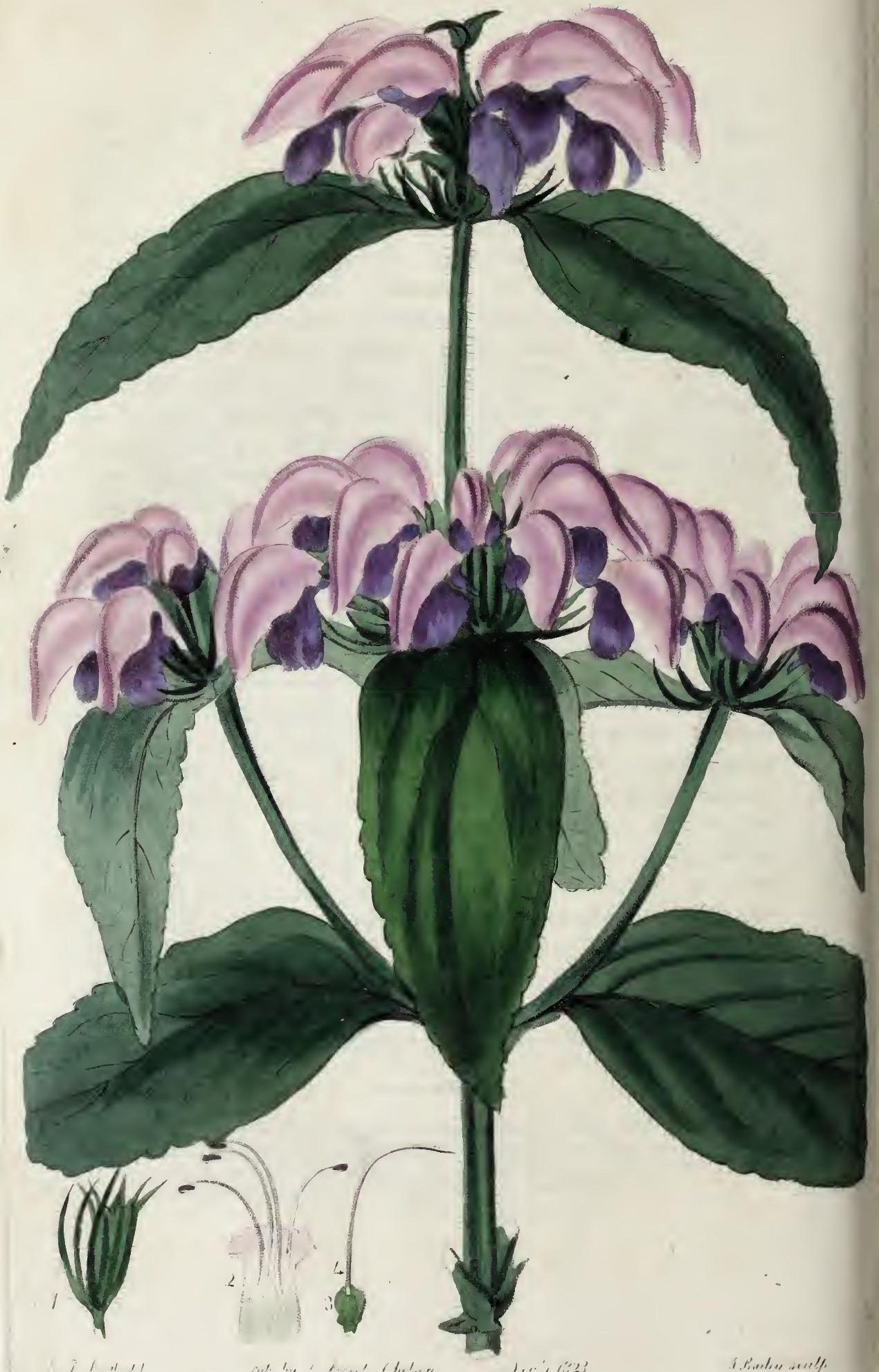




\section{3 \\ PHLOMIS pungens. \\ Pungent-bracted Phlomis.}

Natural Order. Labiata. Brown prodr. 499.

PHLOMIS. Supra, fol. 24.

P. pungens, foliis petiolatis oblongo-lanceolatis apice serratis superne scabris subtus tomentosis, calycinis dentibus subulatis patentibus, bracteis calyce longitudine subulatis mucronatis. Willden. sp. pl. 3. p. 121. Pers. syn. 2. p. 127.

Perennial. Stem about 18 inches high, branching; branches obtusely quadrangular, furrowed, thickly clothed with long villous hairs, and short down intermixed. Leaves opposite, oblong or lanceolate, pointed, entire at the base, and serrated from about the middle with blunt serratures; upper side rather wrinkled, roughish, hairy; under side tomentose, many nerved, reticulately veined. Petioles short and flat, widened at the base, villous. Flowers in whorls, 10 or 12 in each, of a dingy purple. Bractes numerous, rigid, subulate, taper-pointed, fringed, about the length of the calyx. Calyx tubular, narrowest at the base, villous, 5-angled, each angle terminated with a long subulate spreading segment, and between each angle is another smaller one; segments fringed. $\mathrm{Co}$ rolla tubular, 2-lipped, woolly; helmet keeled, sides compressed, slightly bearded, emarginate; lower lip 3 -lobed ; terminal lobe broad, rounded, keeled underneath ; side lobes lanceolate, taper-pointed. Stamens 4, 2 rather longer than the others, inserted in the mouth of the corolla; filaments hairy; anthers incumbent. 
Seeds 4, naked, smooth and shining. Style smooth, about the length of the stamens. Stigma forked, the upper fork scarcely discernible; lower one elongated, taper-pointed.

For the opportunity of giving a figure of this rare and handsome plant, we are indebted to Mr. W. Anderson, Curator of the Apothecaries Company's Garden, at Chelsea, where our drawing was taken in August last; and we do not know that it is in any other collection. It is a native of Armenia, Persia, and Siberia, and only requires planting in the open border of the flower garden, in a light rich soil ; being quite hardy and of easy culture, makes it a very valuable acquisition to our gardens; but it will be some time before it becomes common, except it produces perfect seeds, which we think it likely to do, especially if some pollen be attached to the stigma when the flowers are in perfection. If seeds are procured, we would recommend their being sown in pots as soon as ripe, and protected in a frame during Winter; as many seeds of hardy perennial plants will grow well and come up soon, if sown as soon as ripe; which, if kept till Spring, will either not grow at all, or be a long time in coming up.

1. Calyx, showing its 5 spreading subulate segments, with its pungent bractes at the base. 2. Corolla spread open, showing the insertion of the stamens with their hairy filaments. 3. The 4 seeds. 4. Style terminated with an unequal forked stigma. 



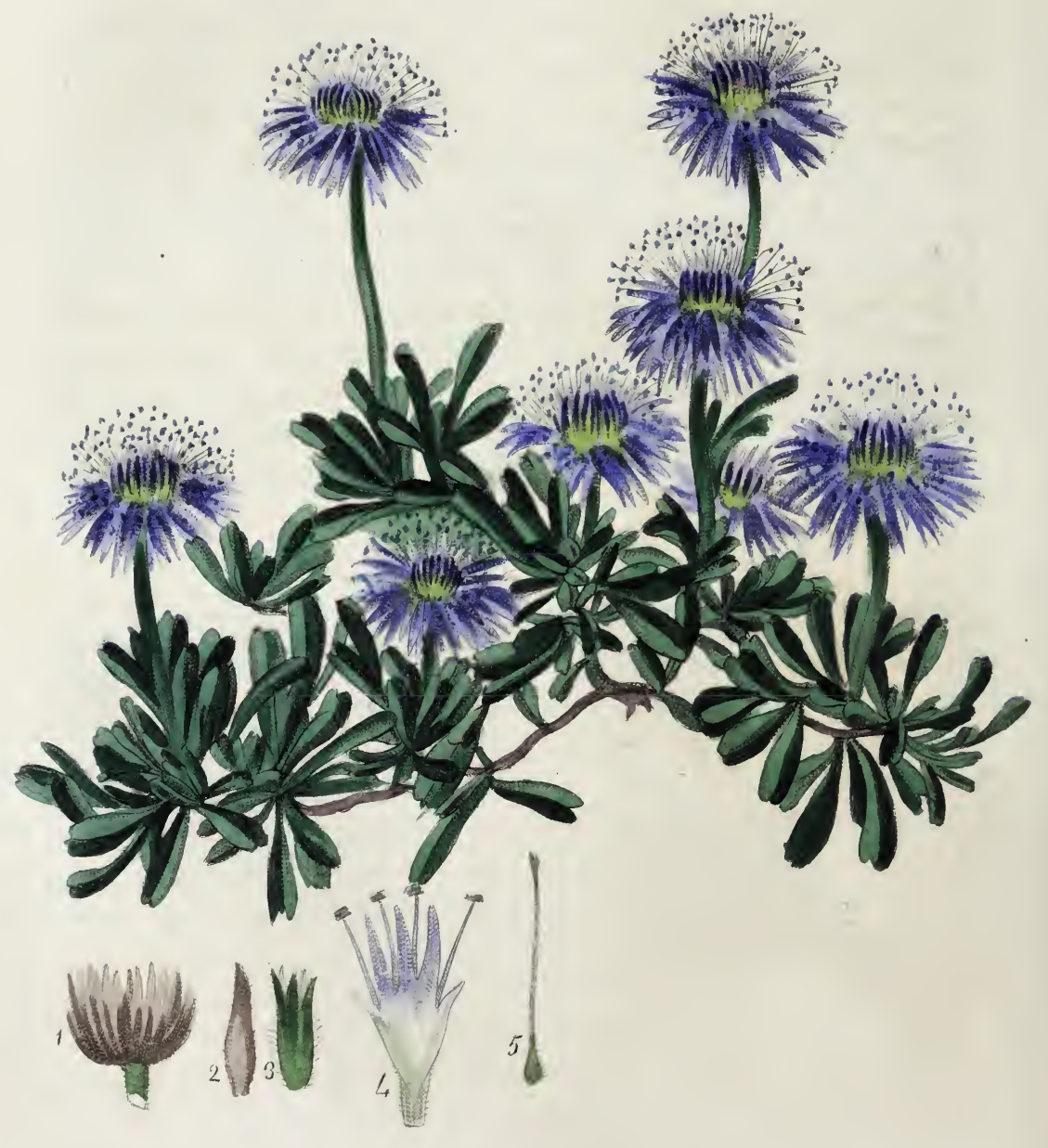




\title{
GLOBULARIA cordifolia.
}

\author{
Wedge-leaved Globularia.
}

Natural Order. Globularina. Link enum. 1. $p .123$. GLOBULARIA. Supra, fol. 20.

G. cordifolia, caule subnudo, foliis cuneiformibus tridentatis: dente intermedio minimo. Pers. syn. 1. p. 118.

Globularia cordifolia. Willden. sp. pl. 1. p.541. Hort. Kew. ed. 2. v. 1. p. 223. Rom. et Schult. syst. 3. p.40. Jacq. aust. 3. p. 26. t. 245. Lam. ill. gen. t.56.f. 2.

Root perennial. Stems numerous, prostrate, much branched, and extended to a considerable distance, smooth and shining, of a dull purple colour. Leaves numerous, crowded, smooth and shining, wedgeshaped, attenuated down the petiole, 3-toothed at the end, the middle tooth very small; margins unequal, rough, but scarcely crenulate. Petioles channelled on the upper side, and convex on the lower. Flowerstalks naked, or with here and there a small leaf on them, angular, deeply furrowed, with numerous unequal furrows; in our specimen, from 2 to 3 inches long. Flowers pale blue, tinged with white. Involucre or Common Calyx imbricate; leaflets rigid, spatulatelylanceolate, obtuse. Receptacle paleaceous. Proper Calyx tubular, very hairy below the segments, 5 -cleft; 2 lower segments broadest, lanceolate, taper-pointed; upper ones subulate. Corolla tubular, 2-lipped; upper lip 2-parted, segments very narrow, obtuse; lower lip 3-parted, segments larger, bluntish. Stamens 4, inserted in the tube; filaments long and slender; anthers 
incumbent; pollen whitish. Germen superior. Style smooth, scarcely as long as the stamens. Stigma 1, very small, capitate. Seed 1, enclosed in the persistent calyx.

This pretty little Alpine plant is very proper for ornamenting rock-work, or for planting on a naked bank, where its prostrate brauches will grow to some distance, and by its numerous leaves and young branches, will make a pretty green tuft, which, in July and August, will be beautified by its elegant little heads of handsome blue flowers. It may also be grown with advantage in a small pot, where it will bloom very well. It is a native of mountainous and Alpine situations in various parts of Europe, and is quite hardy, thriving best in a light sandy soil, and rather a dry situation, being apt to rot and die at the root, if the ground in which it is planted be too moist. It may be increased by dividing at the root; or cuttings planted under hand-glasses in Spring, will strike root, and make nice young plants by Autumn; when rooted, they should be hardened to the air by degrees; at first, taking off the glass at night and keeping it on by day; they may then be potted, and protected in a dry situation through the Winter.

Our drawing was taken from a plant received from the Nursery of Mr. Knight, of the King's Road.

1. Involucre, showing its chaffy receptacle. 2. Scale of the chaff. 3. Calyx. 4. Corolla split open, showing the insertion of the 4 Stamens. 5. Germen, Style, and Stigma, all slightly magnified. 



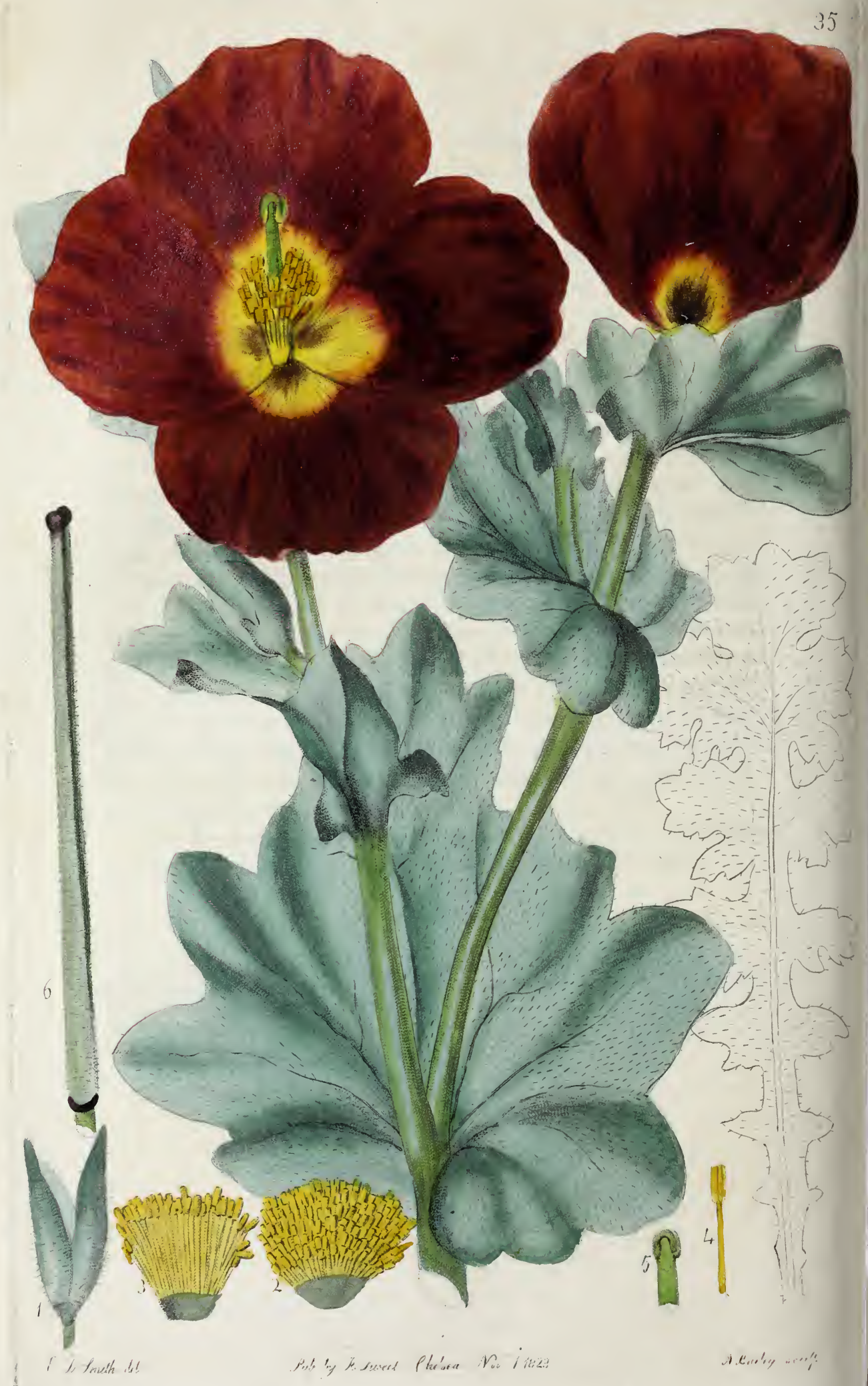




\title{
G L A U C I U M fulvum.
}

\author{
Orange-coloured Horned Poppy.
}

Natural Order. PaPaveracese. DC. Reg. veg. syst. nat. 2. p. 67.

GLAUCIUM. Sepala 2. Petala 4. Stamina numerosa. Capsula siliquæformis, bivalvis, valvulis ab apice ad basin dehiscentibus, bilocularis, placentis nempè dissepimento spongioso cellulari conjunctis, stigmate bilamellato margine incrassato glanduloso demùm quasi bilabiato coronata. Semina intra dissepimenti foveolas subnidulantia, scrobiculata, crista glandulosâ destituta, ovato-reniformia.

Herbæ biennes, sempervirentes, glauca, succo croceo acri scatentes. Radices perpendiculares. Folia radicalia petiolata, caulina sessilia imò amplexicaulia, pinnatim plus minusve incisa, lobis latis obtusis apice interdum mucronuiatis. Pedunculi axillares et terminales, solitarii, uniflori. Flores flavi aut subphonicei, majores quàm in Chelidonio. DC. p.94.

G. fulvum, caule glabro, foliis caulinis rotundato-sinuatis, siliquis scabris, floribus subsessilibus. DC. loc. cit.

Glaucium fulvum. Smith exot. bot.1.p.11.t. \%. in Rees cycl. n. 2. Willd. enum. 562. Hort. Kew. ed. 2. v. 3. p. 288. Link enum. 2. p. 68.

Chelidonium glabrum. Mill. dict. $n .5$.

Chelidonium fulvum. Poir. supl. 5. p. 606.

Biennial, or, perhaps, Perennial. Stems erect, branching, smooth, or with here and there a hair scattered on them, glaucous, from 18 inches to 2 feet in height. Leaves glaucous, thickly clothed underneath with long rigid white hairs, and densely above with shorter ones; lower ones petiolate, pinnatifid, segments more or less lobed, lobes bluntly rounded; upper leaves clasping the stem, cordately auriculate at the 
base, broadly ovate, sinuate, sinuses broadly lobed and bluntly toothed, less hairy underneath. Flowers shortly peduncled, nearly sessile on the upper part of the stem, of a reddish orange colour, yellow at the base. Peduncle opposite to the leaf, short, cylindrical, smooth and glaucous, sometimes terminating with a few white hairs. Bud before expansion ovately oblong, tapering to a point, thickly clothed with bristle like hairs. Calyx of 2 sepals, which drop off as soon as the flower expands. Petals 4, undulate, the 2 outer ones much larger than the others; outer ones orbicular; inner ones obovate, with a yellow spot at the base, and on the yellow spot is a brown mark. Stamens above 100, the inner ones longest; filaments smooth, yellow, attached to the base of the anthers, which are 2-celled, and open longitudinally to discharge the pollen; pollen bright yellow. Siliqua rough, occasioned by the small tubercles with which it is covered. Stigma sessile, bilamellate, crested with a glandularly thickened margin.

The present handsome plant, a native of the South of Europe, is, by some, considered biennial, by others, perennial; we are inclined to believe it perennial, but very liable to perish in Winter by too much moisture at its roots; this is not so much to be lamented, as it produces plenty of perfect seeds, and the plants raised from these will flower the same Summer; and, if the Autumn prove mild, will also ripen their seeds the same year; it is therefore sold as a hardy annual at the Nurseries.

Drawn at the Nursery of Mr. Colvill, from a plant about 18 inches high, that flowered the first year from seed.

1. Calyx. 2. Stamens, front view. 3. The same split open, to show the longest Stamens in the middle. 4. One detached. 5. The bilamellate Stigma. 6. The rough tubercled siliquiform Capsule. 



\section{6 \\ MAZUS rugosus.}

China Mazus.

Natural Order. Scrophularina., Brown prodr. 433.

Sect. II. Stamina 4 antherifera.

MAZUS. Calyx campanulatus, 5-fidus, æqualis. Corolla ringens, labio superiore bilobo, lateribus reflexis ; inferiore trifido, lobis integris, basi bigibbosâ. Stamina didynama. Stigma bilamellatum. Capsula inclusa, bilocularis, bivalvis; valvis integris, medio septiferis.

Herbæ humiles. Folia ad radicem conferta, caulina dum ulla opposita. Scapi racemoso-multiflori vel uniflori; pedicellis alternis, basi v. medio unibracteatis. Brown prodr. 439.

M. rugosus, racemo laxo caulem paucifolium superante, calycibus pubescentibus; fructiferis acutis. Hort. Kew.ed. 2. v. 4. p. 53.

Mazus rugosus. Lour. cochinch. 385. Pers. syn. 2. p. 164.

Lindernia japonica. Willden. $s p$ pl.3. p. 326. Pers. syn.2. p. 166.

Hornemannia bicolor, foliis obovatis basi integerrimis, calycibus patulis pedunculisque glabris. Willd. enum. 654. Link enum. 2. $p .143$.

Gratiola goodenifolia. Hornem. hafn. 19.

Annual. Stems short, tufted, decumbent, branching in all directions, flexuose, slightly angular, and clothed with short white hairs. Leaves opposite, obovate, or sometimes oblong, attenuated to the base, deeply but distantly toothed, rugose, minutely punctate, glossy; nerves and margins slightly hairy. Racemes terminal, elongated, many flowered. Flowers distant, spreading. Bractes small, 1 on each pedicle, a little above the base, lanceolate, taper-pointed, keeled. Pedicles flattened, slightly pubescent, a little longer than the calyx. 
Caly $x$ campanulate, 5 -angular, 5 -cleft ; segments acute, keeled, at first lanceolate, but continuing to grow till they become oblong or ovate, pubescent, spreading. Corolla ringent : upper lip small, ovate, 2-lobed, of a bluish purple; lower lip trifid, spreading, with 2 deep channels underneath, and 2 gibbous ridges above, white slightly tinged with blue, and on the ridges and between them are numerous brownish yellow spots, and clubbed hairs, or pedicled glands. Stamens 4, 2 longer than the others; filaments smooth, attached to the tube; anthers twin, at first distinct, but when burst, each pair are attached by the pollen. Germen smooth, dotted. Style smooth, terminated by a bilamellated stigma.

The present little plant is a native of China; the one from which our drawing was taken, was raised this Spring at the Nursery of Mr. Colvill, from seeds received from the Botanic Garden at Berlin, under the name of Hornemannia bicolor. It is a hardy annual; and the plants begin to flower when they are scarcely 2 inches high, and continue to bloom all the Summer, and ripen plenty of seeds, growing in pretty round tufts, the branches spreading prostrate on the ground in different directions. Being of small growth, and spreading flat on the ground, it should be sown at the front of the flower-borders; the proper time for sowing them, is about the middle of April ; if sown earlier, they will be liable to be injured by the Spring frost. Though not so showy as some other annuals, it is still very pretty and curious, and causes a variety, which is always interesting.

1. Calyx. 2. Corolla split open, to show the insertion of the stamens. 3. The same, with its point bent back to show the pedicled glands. 4. Shows the 2 ridges in the mouth. 6 . Stamen. 6. Germen, Style, and bilamellated Stigma. 



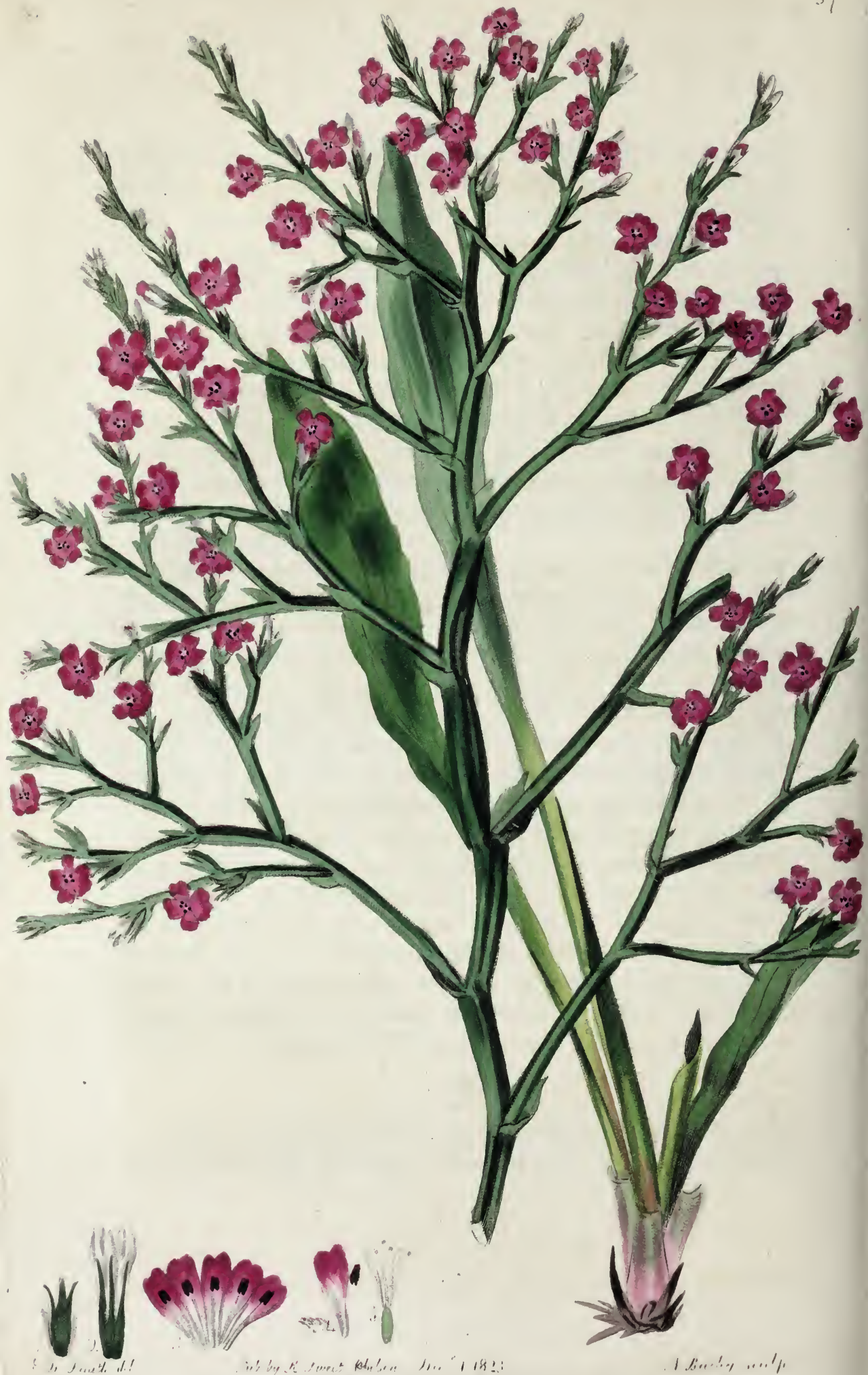




\section{7}

\section{TAXANTHEMA tatarica.}

Tartarian Sea Lavender.

Natural Order. Plumbaginea. Brown prodr. 425.

TAX ANTHEMA. Calyx infundibuliformis, limbo scarioso, 5-plicato, 5-dentato. Corolla 5-petala, v. 5-partita. Stamina 5, unguibus petalorum inserta. Styli 5, rarò 3, distincti. Capsula evalvis, membranacea. Semen albuminosum. Spica secundæ, floribus 2-3-bracteatis. Herbæ $v$. Suffrutices. Caule scapove diviso. Brown prodr. 426.

T. tatarica, scapo ramoso divaricato; ramis triquetris, floribus distantibus, foliis lanceolato-obovato mucronatis.

Statice tatarica. Willden. sp. pl. 1. p. 1527. Pers. syn. 1. p. 333. Hort. Kew. ed. 2. v. 2. p. 182.

Statice foliis lanceolatis mucronatis radicalibus, caule ancipiti dichotomo, floribus alternis distantibus. Gmel. sibir. 2. p. 223. t. 92 .

Perennial. Root large, fusiform, branching. Leaves lanceolate, or lanceolately obovate, slightly undulate, mucronate, attenuated to the base, into a kind of footstalk; much veined, of a hoary white colour, the base tinged with red, as are the young leaves; margins cartilaginous, roughish. Flower-stems several, from a foot to 18 inches in height, 3-sided, very much branched; branches 3 -sided, flexuose, all leaning one way, paniculately branching, and spreading in all directions, each enclosed at the base by a lanceolate, taper-pointed, keeled bracte. Spikes secund, the flowers all leaning to one side, rather distant, alternate, solitary, or in pairs, surrounded by 2 or 3 bractes, one of which is simple, lanceolate, taper-pointed, and keeled; the others 3-forked, and acute, membranaceous at the base. Calyx funnel-form, with a scariose, 5-plaited, 5-toothed limb, of a white colour, with 
5 green or brown stripes down the tube. Corolla of 5 petals, of a lively red; unguis about even with the calyx, limb spreading. Stamens 5 , inserted in the unguis; filaments smooth, attached to the anthers by the back; anthers exserted above the mouth. Styles 5, thickly clothed with short gland-like hairs. Stigmas 5, green, capitate.

Our drawing of this rare and beautiful species was taken from a fine plant, at the Garden of the Apothecaries' Company, at Chelsea; where it thrives well in the open border, and flowers from July to October, some of the flowering branches attaining to the height of 18 inches; it thrives best in a light sandy soil, but is slow of increase, except by seeds, which sometimes ripen. The plants, when grown strong, will sometimes bear dividing, by being carefully cut through the middle, leaving a part of the root to each piece; the best time for doing this is in October, as the plants then make ycung roots by Spring; if they are divided in Spring, they are very apt to die off, particularly if the weather sets in dry and warm. The seeds should be sown as early as possible, the latter end of February, or beginning of March, if the weather prove mild; if they are sown in pots, and kept in a frame, or the greenhouse, till they come up, they will succeed best ; planting them off in other pots, or in a bed of nice light soil as soon as possible, as they are very liable to die off if left too long in the seed-pots.

We have adopted the genus TAXANTHEMA, of Necker, from Mr. Brown's Prodromus; the original genus Sratice of Tournefort, which we adopt, is composed of the section ARMERIA; the division is also adopted by the German Botanists, but they have used ARMERIA for a generic name, and continued STATICE to the spiked species.

1. The 3-forked Bracte. 2. Calyx. 3. Corolla spread open, showing the insertion of the Stamens at the base of the petals. 4. Petal separate, with the Stamen inserted in its base. 5. Germen terminated by the 5 Styles and capitate Stigmas. 



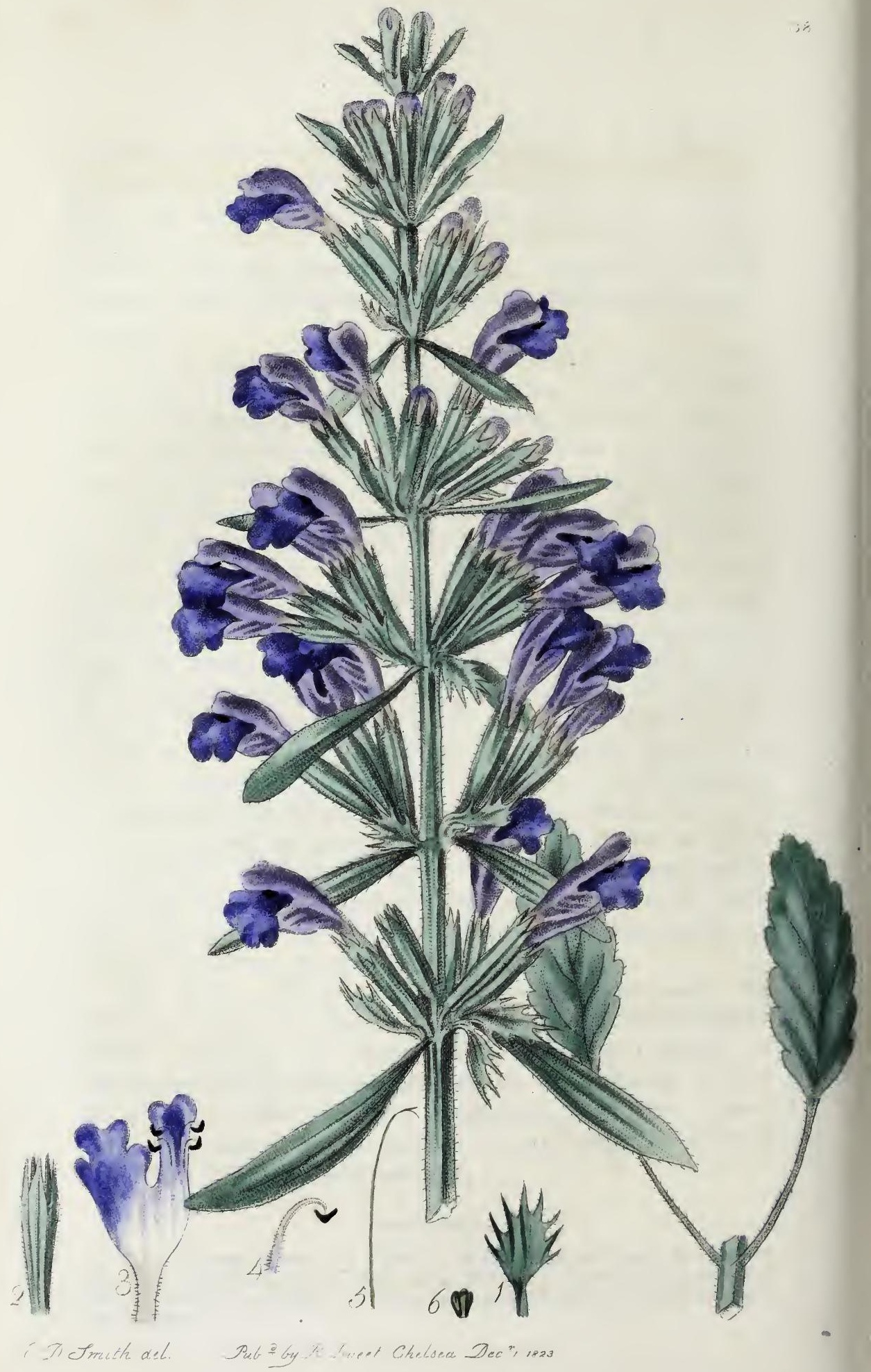




\title{
38
}

\section{DRACOCEPHALUM canescens.}

\author{
Hoary-leaved Dragon's-head.
}

Natural Order. Labiate. Brown prodr. 499.

Sect. IV. Stamina 4-fertilia. Corolla bilabiata. Calyx bilabiatus. Juss. gen. 115.

DRACOCEPHALUM. Calyx 5-fidus, 2-labiatus in Moldavicâ T. subæqualis in cæteris. Corolla fauce inflata, labiata, superius fornicata, integra in Dracocephalo T. emarginata in aliis, inferius 3-loba, laciniis lateralibus brevibus erectis, media majore et productiore, integrâ aut 2-lobâ. Herba aut rarò suffrutices; flores verticillato-spicati terminales, aut pedunculi axillares uni vel multiflori, bracteati bracteis latis interdìm ciliatis, in D. Virginiano angustis minimis. Juss. gen. 116.

D. canescens, floribus verticillatis, bracteis oblongis ciliatis, foliis oblongis canescentibus : inferioribus serratis ; superioribus integerrimis, calycibus striatis pubescentibus, tubo corollæ calyce longiore.

Dracocephalum canescens. Willden. sp. pl. 3. p. 156. Pers. syn. 2. p. 133. Hort. Kew. ed. 2. v. 3. p. 420.

Annual. Stem nearly erect, or ascending, bluntly 4-sided, much branched ; branches opposite, crossing each other, clothed with a short white pubescence. Leaves opposite, petiolate, oblong, blunt, strongly and numerously nerved underneath, covered on both sides with a short close canescent pubescence; lower ones broadest, and serrated; upper ones narrower, and entire, becoming nearly linear on the upper part of the stem. Flowers in whorls round the stem, of a bright violet blue. Bractes 4, at the base of each whorl, petiolate, oblong, or ovate, concave, and fringed with spine like bristles. Pedicles short, compressed, 
pubescent. Calyx 5-cleft, striated, pubescent, upper segment double the width of the others, bluntish; lower ones taper-pointed, mucronate. Corolla tubular, inflated at the mouth, 2-lipped; upper lip emarginate, concave, doubling in so as to enclose the stamens; lower lip 3-lobed, end lobe very broad, emarginate, recurved, side ones short and blunt, rounded. Stamens 4, inserted in the mouth, 2 a little longer than the others, declining: filaments bearded at the base, and smooth from about the middle; anthers incumbent. Style smooth and glossy. Stigma 2-cleft, with acute points.

A beautiful hardy annual, native of the Levant, and seldom now to be met with in any collection, which is rather surprising, as it is much more showy than many others that are now generally cultivated; it only requires to be sown in the open borders in the common garden soil, and to be kept clear of weeds; the best time for sowing the seeds is the beginning of March, if the weather proves favourable; the plants will then get strong, and flower abundantly all the latter part of Summer.

A patch of these plants were grown this last Summer at the Nursery of Mr. Colvill, from whence our drawing was made. They grew to the height of from 18 inches to 2 feet, branching on every side, and were covered with flowers nearly the whole of their length at the same time, which made an elegant appearance. Our Figure cannot do justice to the original for want of room; but from it may be inferred what the plants really were.

1. The fringed Bracte. 2. Calyx. 3. Corolla spread open, to show the insertion of the Stamens. 4. Stamen detached. 5. Style, and cleft Stigma. 6. The 4 naked Seeds. 



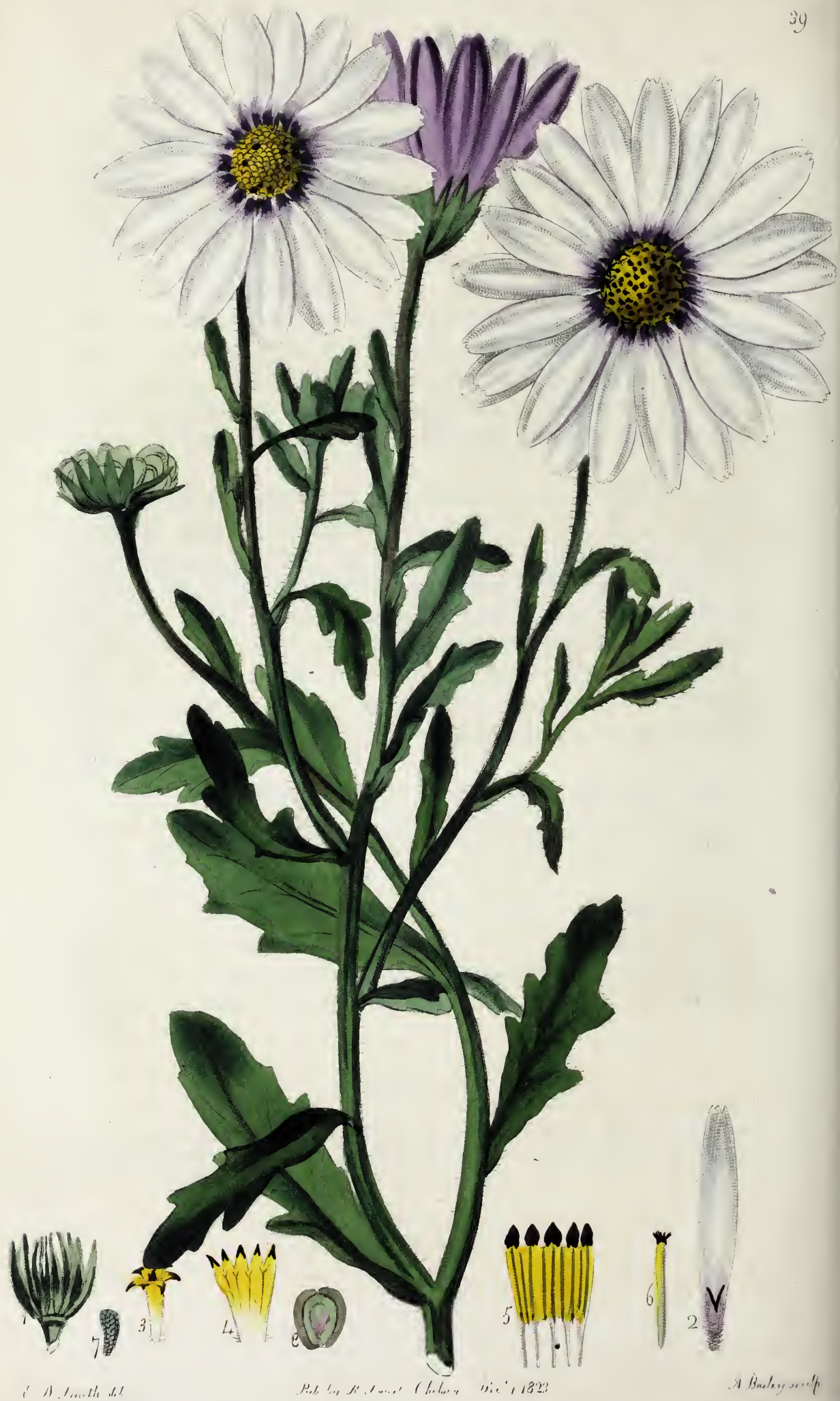




\section{CALENDULA hybrida.}

\section{Great Cape Marygold.}

Natural Order. Composita. Adanson fam. 2.103.

CALENDULA. Flores radiati ; flosculi centrales masculi, ambientes hermaphroditi; ligulæ foemineæ. Involucrum simplex polyphyllum æquale. Receptaculum nudum. Pappus nullus. Semina sæpè membranacea; marginalia diversa ab interioribus, incurva sub ligulis luteis in C. Europeis, aut in C. Africanis cordato-plana sub ligulis albo-violaceis. Flores scepè solitarii terminales. Species plurima fruticulosa.

C. hybrida, foliis oblongo-lanceolatis obtusis dentatis, caule folioso, pedunculis superne incrassatis. Willden. $s p . p l .3$. p. 2342.

Calendula hybrida. Pers. syn. 2. p. 492. Hort. Kew. ed.2. v. 5. p. 167. Schkuhr handb. 3. p. 173. t. 264.

Root annual. Stem about a foot high, much branched; branches spreading in all directions, of a purplish colour, thickly clothed with short white spreading unequal hairs, as are the leaves, peduncles, and calyx. Leaves sessile; lower ones spatulately oblong, obtuse, rather carnose, and toothed here and there with large blunt teeth; upper ones alternate, narrower, and more acute, oblong, or lanceolate, and toothed on each side with 1 or 2 smaller pointed teeth. Peduncles terminal, gradually increasing in size upwards, much thickened just below the flower, and particularly when in fruit; 1-flowered. Involucre simple, many-leaved; scales nearly equal, linearly-lanceolate, taper-pointed, with fringed membranaceous margins. Receptacle slightly convex, naked, dotted. Ligula, or Rays, fertile, densely fringed at the base 
with long white hairs, and terminated at the point with 3 short teeth; upper side pure white; the under side of a bright purple, or violet, bearing no stamens, but a filiform style, and purple bifid stigma; florets in the centre tubular, 5-cleft, hairy at the base, barren, only producing stamens; outer ones fertile, also 5-cleft, bearing both stamens and pistils. Stamens 5 ; filaments distinct; anthers connected into a tube. Style extending just above the stamens. Stigmas 2, blunt, fringed. Seeds from the ray spatulate, rugose; those from the disk obcordate, with a thin membranaceous margin.

A very handsome hardy annual, only requiring to be sown in the open borders, and to be kept clear of weeds. It must not be sown too early in the Spring, being a native of the Cape, as the Spring frosts would be liable to injure it; the latter end of April, or beginning of May, according as the weather suits, is the best time for sowing the seeds; they will then flower from July to October, if the season continue mild, and will ripen plenty of seeds.

Our drawing was taken at the Nursery of Mr. Colvill, where the plants were about 15 inches in height, and very bushy; and they continued in flower this year till the end of October.

1. Involucre cut through the middle, to show the dotted receptacle. 2. Floret of the ray, showing its 2 stigmas. 3. Fertile floret of the disk. 4. The same laid open, showing its nerves alternating with the teeth. 5. The 5 Stamens spread open, to show the united anthers, and distinct filaments. 6. Style of the floret of the disk, crowned with its fringed stigmas. 7. Seed from the ray. 8. Seed from the disk. 



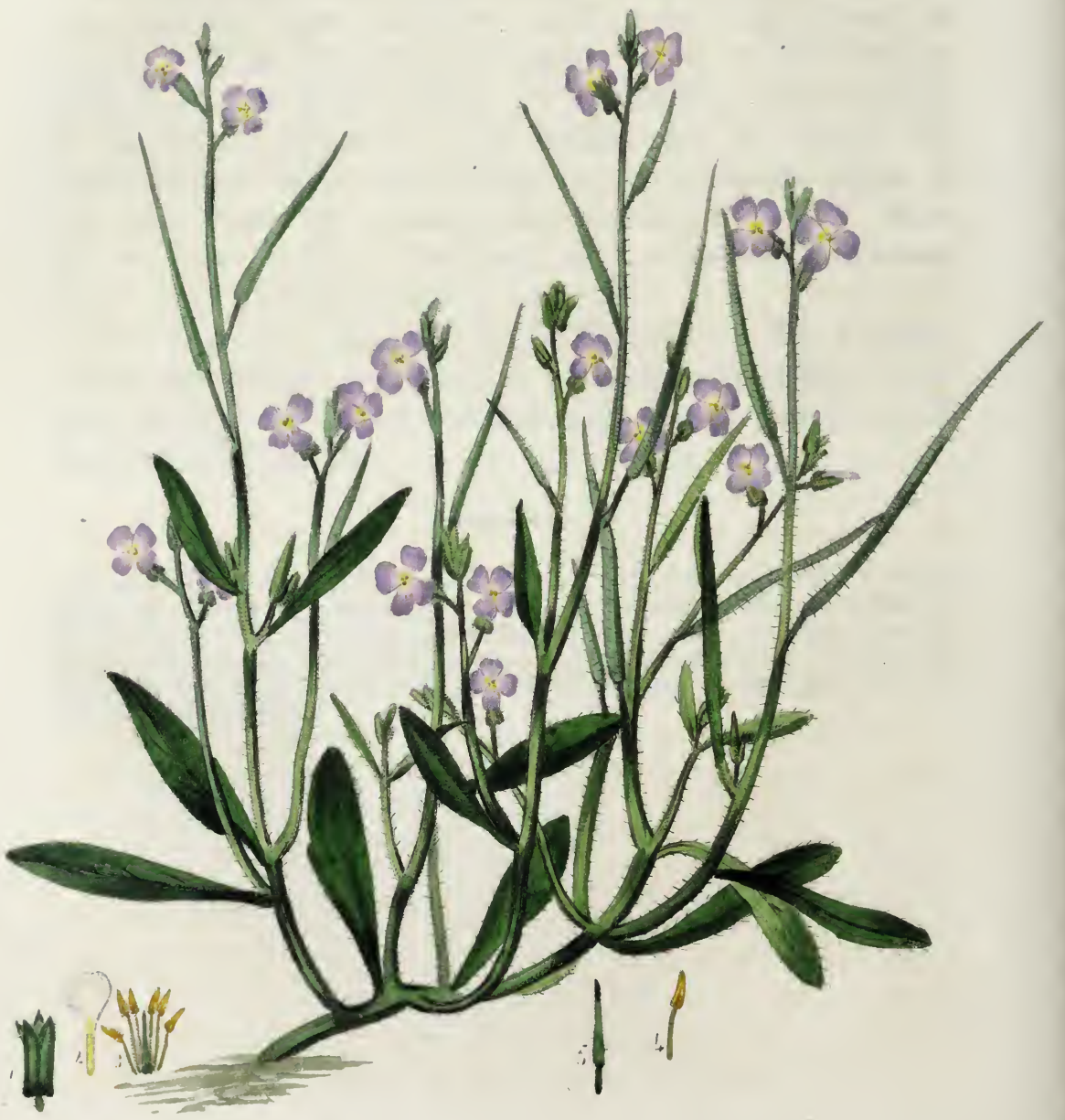




\section{0}

\section{MALCOMIA Chia.}

Dwarf branching Malcomia.

Natural Order. Crucifere. DC. Reg. veg. syst. nat. ข. 2. p. 139.

Subordo II. NOTORHIZEE. DC. p. 150.

Cotyledones planæ, incumbentes. Radicula dorsalis. Semina ovata, immarginata.

Tribus VII. SISYMBREE seu NOTORHIZEE SILIQUOSE. Siliqua bilocularis longitudinaliter dehiscens, valvis concavis carinatisve. Semina ovata aut oblonga, immarginata. Cotyledones planæ, incumbentes, septo contrariæ.

MALCOMIA. Calyx clausus, nunc basi bigibbus, nunc subæqualis. Petala limbo obovata aut obtusissimè emarginato. Stamina tetradynama, libera, edentula. Siliqua teres, 2-locularis, 2-valvis, stigmate acutissimo simplici terminata. Semina ovata, 1-serialia, immarginata. Cotyledones planæ, incumbentes. Herbæ annuс aut perennes, pilis stellatis sapius scabra aut velutince. Folia oblonga aut ovalia, integra dentata aut sinuatopinnatifida. Pedicelli in racemum digesti, ebracteati. Flores purpurascentes aut albi, interdum minimi, in hortis non duplices evadunt. DC. p. 438.

M. Chia, caule erecto ramoso, foliis obovatis integris pube bipartitâ adpressâ, pedicellis calycis longitudine, siliquis teretiusculis pubescentibus, stylo brevissimo. DC. $p .440$.

Malcolmia Chia. Link enum. p. 167.

Cheiranthus Chius. Lin. sp. 924. Mill. divt. n. 13. Willd. sp. pl. 3. p. 518.

Hesperis Chia. Lam. dict. 3. p. 324. Pers. syn. 2. p. 203.

Hesperis siliquis hirsutis flore parvo rubello. Dill. elt. 180. t. 147. $f .178$.

Annual. Root slender, small, fibrous. Stems much branched, from 6 to 12 inches high, cylindrical, pubescent, the hairs close-pressed, and affixed by their middle. Leaves pubescent underneath, the hairs 2-parted, entire, or rarely toothed; lower ones obovate, 
or spathulate, attenuated down the petiole, blunt, or emarginate at the point; stem ones narrower and more acute, tapering to the base. Racemes 3 to 9-flowered, lengthening after flowering. Pedicles cylindrical, about 3 lines long. Calyx of 4 sepals, gibbous on each side at the base, about the length or a little longer than the pedicles; sepals linear, acute. Flowers of a purplish lilac, about half the size of M. maritima; petals obovate, emarginate, their ungues about the length of the calyx. Stamens, 4 long, and 2 short. Pod straight, nearly cylindrical, pubescent when young. Style very short and acute.

MALCOMIA was first established as a distinct genus by Mr. Brown, in the second edition of the Hortus Kewensis, and contains a natural and distinct group of plants that had been hitherto referred to CHEIRANTHUS and HESPERIS; and M. Decandolle has described 15 species, 12 of them annual, 1 biennial, and 2 perennial. The present species is annual, and very proper for the edging of borders, or to be sown in clumps near the edges of flower borders, in the same manner as the more common M. maritima, (generally known by the name of Virginian Stock;) the seeds may be sown any time between February and June; and by sowing them at various seasons, a succession of flowers may be kept up all the Summer; those sown the early part of the season, will produce plenty of seeds; whereas them that are sown later, will be more doubtful, and their seeding will depend on the mildness of the season.

Our drawing was taken at the Nursery of Mr. Colvill, in June last.

1. Calyx. 2. Petal. 3. The 6 Stamens with the young Siliqua in the midst of them. 4. Stamen detached. 5. The young Siliqua terminated with a short acute Style, all slightly magnified. 


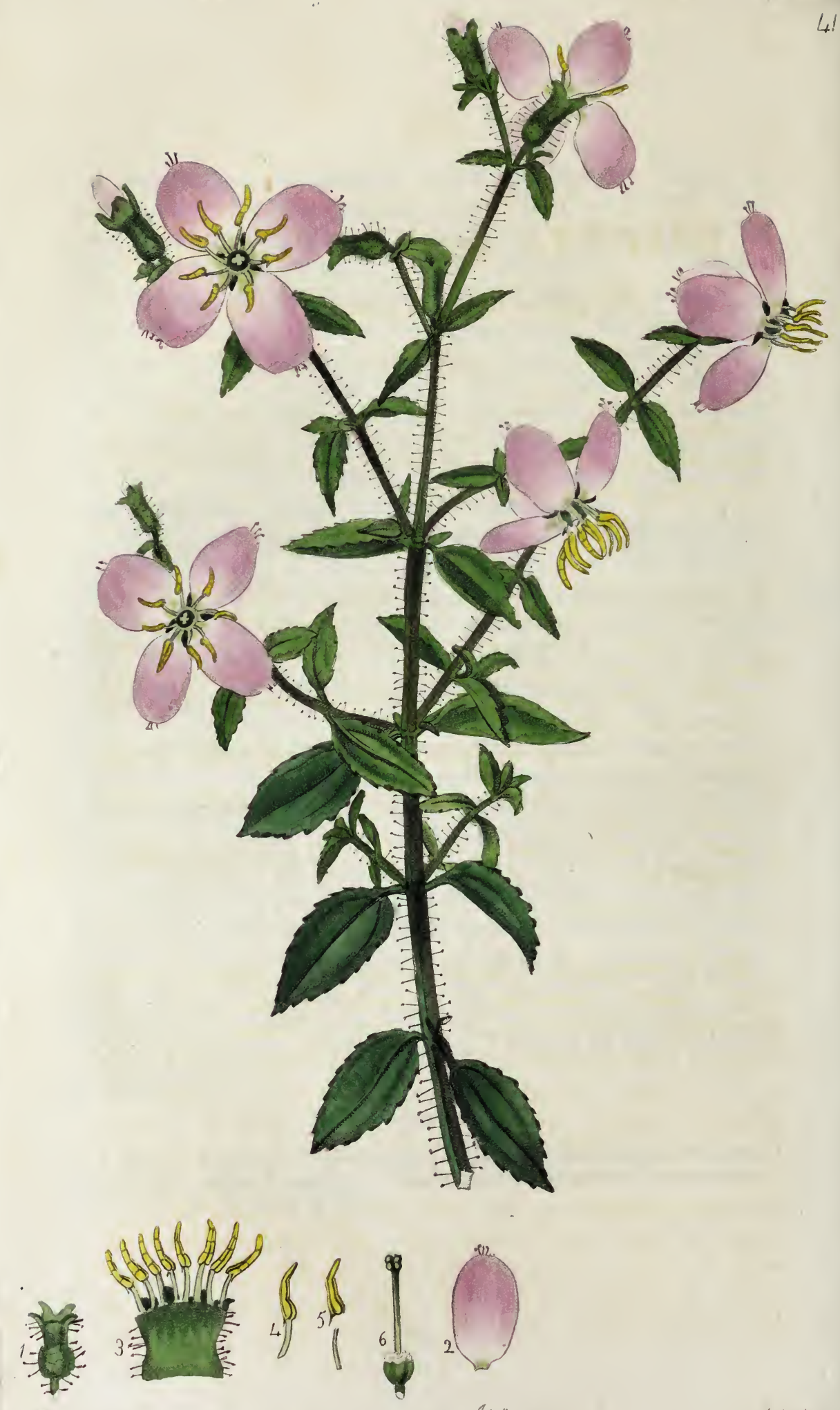


\title{
RHEXIA mariana. $\beta$ rubella.
}

\author{
Maryland Rhexia, stained variety.
}

Natural Order. Melastomacez. Juss. gen. 328.

RHEXIA. Calyx urceolatus, quadrifidus. Corolla 4-petala, calyci inserta. Stamina 8, antheris declinatis. Capsula setosa, 4-locularis, intra ventrem calycis.

R. mariana, caule rufescente hirsutissimo, foliis hirsutis subpetiolatis ovali-lanceolatis lanceolatis linearibusve, calyce longo tubuloso glabriusculo. Pursh. flor. amer. sept. 1. p. $25 \%$.

Rhexia mariana. Mich. fl.amer. 1. p. 22I. Willden. sp.pl.2. p. 301. Pers. syn. 1. p. 406. Hort.Kew.ed.2. v. 2. p. 340. Lamarck ill. 283. $f .1$.

a. purpurea, foliis angusto-lanceolatis vel oblongis, floribus saturate purpureis. Mich. l. c.

ß. rubella, foliis ovali-lanceolatis vel oblongis, floribus dilute rubellis. Mich. l. $c$.

r. exalbida, foliis linearibus, caule hirsutiore, floribus pallidis. Mich.l. c.

Root perennial. Stems numerous, about a foot high, much branched; branches spreading in all directions, bluntly quadrangular, furrowed, thickly clothed with brown spreading rigid hairs, tipped with a red gland. Leaves opposite, 3-nerved, finely but sharply serrate, hairy on both sides, bluntish ; lower ones oval, or oblong, gradually narrowing upwards ; upper ones lanceolate, or linear. Petioles very short. Flowers terminating the branches in a kind of panicle, more or less tinged with red. Peduncles short and stiff, smooth. Calyx urceolately tubular, 4-cleft, angular, smoothish, with a few rigid hairs scattered on it here and there; segments ovate, acute, spreading. 
Petals 4, inserted in the calyx, spreading. Stamens 8, inserted in the calyx; filaments flat, smooth; attached to the anthers a little above their base; anthers linear, declining, with a sharp subulate spur at the back, just above the filament. Style smooth, green, terminated by a papillose capitate stigma.

This rare and handsome species is a native of North America, growing, according to Pursh, in bogs, and sandy woods, near waters, from New Jersey to Carolina, and flowering in July and August; with us it requires as warm a border as possible, and to be planted in a bed of peat earth; it will then thrive well, and flower late in Autumn; if it is not planted in a warm situation, it is a great chance if it flower at all; and, certainly not, except it be a very warm season, though the plant itself is quite hardy, enduring our most severe Winters without any protection, and attaining about a foot in height. Its time of flowering with us, if in a favourable situation, is from the latter end of August, till November, if the weather prove mild. Our drawing of the present specimen, was taken at the Nursery of Mr. Colvill, in October last.

We are inclined to think that more than one species is, at present, confused under R.mariana, from the disagreement of the descriptions of different Authors, and the varieties that are enumerated; we have never seen the least variation in our cultivated plants. The best method of propagating it is by dividing it at the root; or young cuttings planted under a hand-glass in peat soil, will strike root freely.

1. Calyx. 2. Petal. 3. Calyx spread open, showing the insertion of the Stamens. 4. Stamen detached. 5. Anther detached from the filament, showing the spur at the base. 6. Germen, Style, and Stigma. 



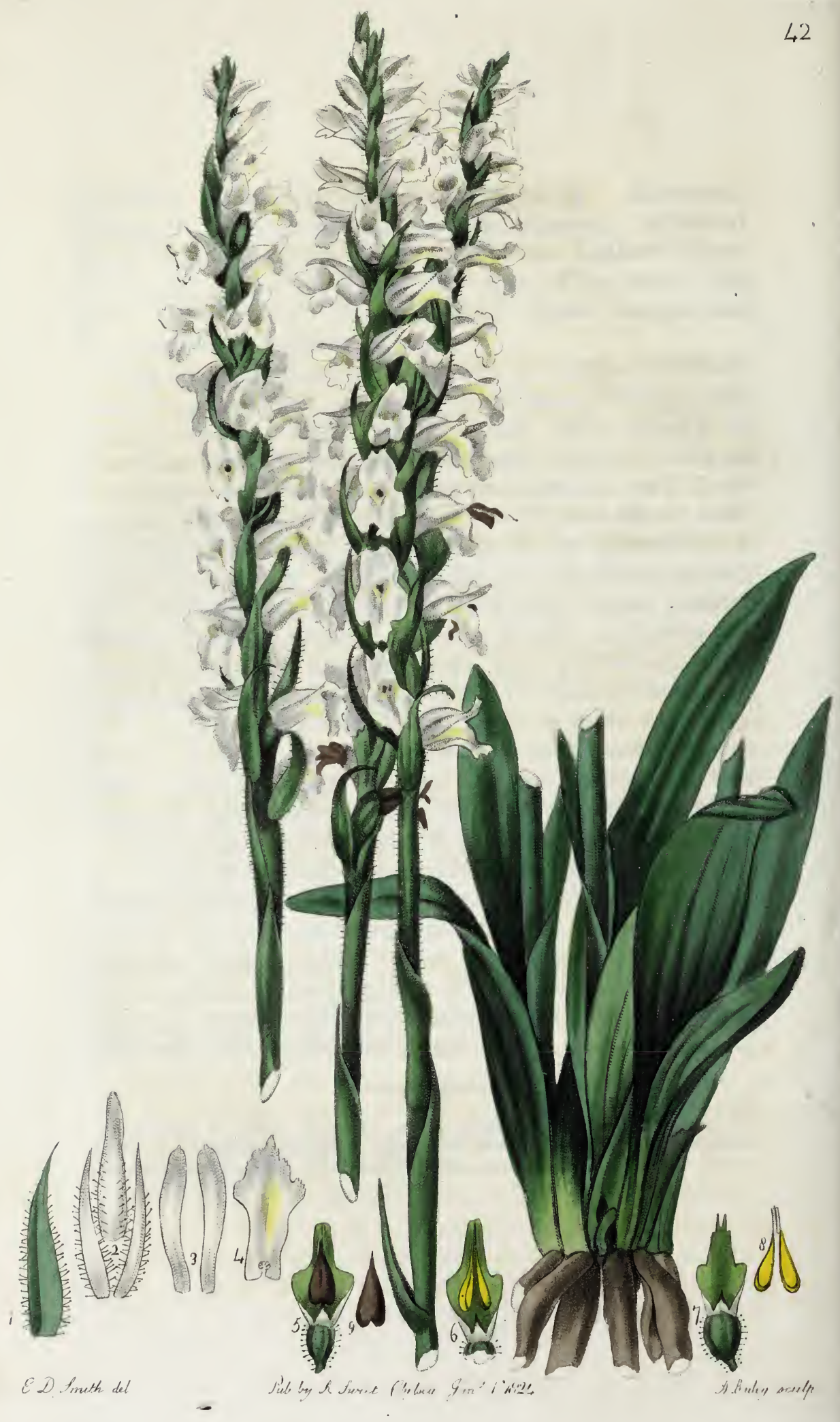




\title{
NEOTTIA cernua.
}

\author{
Nodding-flowered Neottia.
}

Natural Order. ORChidea. Brown prodr. 309.

Sect. II. Monandra. Anthera stigmati parallela, persistens, loculis approximatis. Pollinis massa pulvereæ, in granula (simplicia) facilè solvendæ, apice affixæ filo a stigmatis glandulâ ortum ducenti. Herba Terrestres. Brown. prodr. 314.

NEOTTIA. Perianthium ringens; foliolis exterioribus anticis labello imberbi suppositis; interioribus conniventibus. Columna aptera. Pollen farinaceum. Brown.

N. cernua, bulbis fasciculatis, foliis lanceolatis trinerviis, caule vaginato, spica spiraliter subimbricata pubescente, floribus recurvato-cernuis, labello oblongo integro crenulato.

Neottia cernua. Willden. sp. pl. 4. p. 75. Pers. syn. 2. p. 511. Hort. Kew. ed. 2. vol. 5. p. 199. Pursh. fl. amer. sept. 2. p. 589. Botan. magaz. 1568.

Ophrys cernua. Linn. sp. pl. 1340. Mich. fl. bor. amer. 2. p. 158.

Limodorum autumnale. Walter fl.car. p. 221.

Perennial. Roots composed of a fascicle of oblong bulbs, or tubers. Stems several, from a strong plant. Leaves lanceolate, acute, 3-nerved, attenuated at the base, sheathing the stem, smooth and glossy. Scapes in our specimen about 18 inches in height, leafy, smooth on the lower part, and densely pubescent on the upper. Spikes oblong, from 4 to 6 inches in length, densely pubescent between the flowers. Flowers white, fragrant, spirally arranged, nodding; the upper ones scarcely half the size of the lower ones. Bractes lanceolate, taper-pointed, concave, ciliated with glandular hairs, double the length of the germen, points 
curved inwards. Germen bvate, narrowed at the base, hairy, the hairs tipped with small glands. Perianthium ringent, thickly clothed on the outside with pellucid glandular hairs; three outer leaflets lanceolate, taper-pointed; the upper one stuck to the 2 inner ones for more than half their length, points of the lateral ones bent inwards; two inner ones concave, connivent, and blunter. Labellum oblong, not divided into lobes, more or less acute, margins undulate, crenulate. Column green, not winged. Anther 1, attached to the point of the stigma, and covered with a brown taper-pointed hood.

A very rare and interesting plant, native of North America; its flowers are delightfully fragrant, and they last a long time in beauty; the present specimen having been in bloom from the beginning of August, to the middle of November. It appears to be more free of growth than the plants belonging to this family generally are, as it thrives well in a border of very sandy loam, and appears to be making offsets freely; but we expect it will yet be some time before it becomes common, except others are inported from America. We expect many more species of this interesting family from that country shortly, as Mr. Colvill has applied to a Correspondent there, to send all the species that can be collected; and he has received notice that he may soon expect them, with many other curious plants. last.

Drawn at the Nursery of Mr. Colvill, in September

1. Bracte. 2. The 3 outer leaflets of the Perianthium. 3. The 2 inner ones. 4. The Labellum; showing its crenated margin. 5. The Germen divested of the Perianthium, showing the column, with the Anther in front, covered with its brown hood. 6. The same divested of the hood, the Anther exposed to view. 7. The same divested of the Anther. 8. Inner view of the Anther. 9. The Hood with which the Anther was covered, all highly magnified. 



\title{
IMPATIENS biflora.
}

\author{
Two-flowered Touch me not.
}

\section{Natural Order. Balsaminea.}

IMPATIENS. Calyx 2-sepalus. Corolla 5-petala, hypogyna, irregularia et inæqualia; superius latius fornicatum; inferius breve basi calcaratum; lateralia seu interiora 2 basi appendiculata aut interdum bipartita. Stamina 5 hypogyna, filamentis brevibus primò monadelphis, dein maturatione distinctis, antherarum persistente supernâ coalitione. Germen 1; stylus 0 ; stigma acutum. Capsula oblonga 5-locularis polysperma 5-valvis, elasticè dissiliens valvis in spiram intortis, dissepimentis membranaceis ex receptaculo columnari centrali seminifero enatis et valvularum margini appositis; corculum seminis rectum absque perispermo.

Herbæ; folia alterna aut rariùs opposita, non stipulacea; pedunculi axillares uni aut multiflori. Genus, anteà Papaveraceis adjectum, simile calyce 2-phyllo et corollâ 4-petalâ et stylo nullo, sed discrepans antheris definitis et connatis, fructu multiloculari et multivalvi, receptaculo centrali et foliis interdum oppositis. Extù convenit Geraniis Africanis similiter calcaratis, sed huic ut et Tropaolo calcar liberum, non pedicello inharens ut in Geraniis; diversa insuper staminum et fructús et seminis structura. Genus ergò sui ordinis nunc verè unicum. An pro calyce habenda petala 2 exteriora, calycis munus jam obeuntia in flore nondùm explicato? Juss. gen. 270.

I. biflora, pedunculis plerumque bifloris solitariis, foliis ovatis argute dentatis. Pursh. fl. amer. sept. 1. p. 171.

Impatiens biflora. Willd. sp. pl. 1. p. 1175. Walt. flor. car. 219. Pers. syn. 1. p. 257. Hort. sub. lond. 47.

Annual. Stem upright, 2 to 3 feet high, rather flexuose, tumid at the joints, much branched, smooth and glossy; branches spreading in all directions, flexuose, of a glossy purple, angular. Leaves ovate, acute, sharply toothed with short teeth, longer, and sharper at the base, reticulately veined underneath, and furrowed on the upper side, soft and tender, soon 
withering after being gathered. Petioles smooth, flattened and furrowed on the upper side, and convex on the lower. Peduncles axillary, very slender, generally 2 -flowered, continuing to grow till the seeds ripen. Pedicles filiform, with a small subulate bracte about the middle of each. Calyx of 2 sepals, which are roundly ovate, acute, concave, of a membranaceous texture, with a strong green midrib. Flowers pendulous, of a dark yellow, spotted with red on the inside. Petals unequal, irregular. Nectary cowl-shaped, terminated in a blunt spur. Stamens 5 ; filaments short and stout, at first connected, but after the flower is expanded, distinct; anthers 5, connected ; pollen creamcoloured. Germen smooth and glossy, crowned with an acute sligma. Capsule 5-valved, when ripe opening with an elastic spring as soon as touched, the seeds springing out, and the valves of the capsule rolling up.

This very curious annual plant is a native of North America, and is mentioned by Mr. Pursh as growing in wet shady places, from Canada to Carolina. It is quite hardy, and only requires to be sown in the open ground, about the latter end of March, or beginning of April, if the weather is mild, requiring a dampish shady situation, where it will grow to the height of 3 feet, or upwards, and will continue to flower till destroyed by the frost in Autumn; if in a dry exposed situation, it will not grow near so strong, nor last so long in flower. A peculiar property belongs to this plant, and the others belonging to this genus, in the elasticity of their capsules; when the seeds are nearly ripe, if the capsules are ever so lightly pressed, they immediately burst, the valves rolling up, and the seeds springing to a distance, so that it requires much care to procure them.

Our drawing was taken at the Apothecaries' Company's Garden, at Chelsea, in September last.

1. Calyx. 2. Corolla spread open, showing the insertion of the petals. 3. Stamens, spread open to show the connected anthers, and the insertion of the filaments. 4. Germen terminated with an acute Stigma. 5. Capsule burst open, all magnified except the last. 



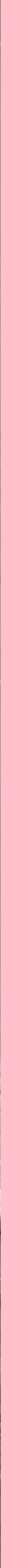




\section{LIATRIS squarrosa.}

Squarrose-cupped Liatris, Rattlesnake's Master.

Natural Order. Composite. Adanson fam. 2. 103.

LIATRIS. Receptaculum nudum. Pappus plumosus, coloratus. Involucrum oblongum, imbricatum.

L. squarrosa, caule simplici pubescente, foliis linearibus nervosis scabris, racemis paucifloris foliosis, involucris turbinatis ; squamis lanceolatis obtusis rigidis patentibus.

Liatris squarrosa. Willden. sp. pl. 3. p.1634. Pers. syn. 2. p. 403. Hort. Kew. ed. 2. v. 4. p. 503. Pursh. flor. amer. sept. 2. p. 509.

Serratula squarrosa. Hort. cliff. 392.

Cirsium tuberosum, eapitulis squarrosis. Dill. elth.83. t. 71 . f. 82.

Root perennial, tuberous. Stem simple, from 18 inches to 2 feet high, pubescent. Leaves long, linear, rough, particularly. at the edges, slightly pubescent, nerved underneath; stem-leaves narrower, those near the flowers shorter, broader at the base, and tapering to the point. Racemes leafy ; flowers distant from each other, the lower ones on long peduncles, upper ones shorter; terminal flower expanding first, the others gradually opening downwards, of a bright purple colour. Peduncles purplish, rough, pubescent, gradually thickening upwards, and tapering to the base, leafy. Involucre turbinate, many-leaved, imbricate; scales lanceolate, obtuse, ronghish, finely ciliate, spreading; upper ones coloured at the points. $\boldsymbol{R} e$ ceptacle naked, convex, punctate. Florets numerous, tubular, 5-cleft; tube about the length of the pappus; laciniæ lanceolate, acute, about half as long as the tube. Stamens 5, inserted in the middle of the tube; filaments slender, distinct, smooth; anthers connected 
by a thin membrane at the base, but distinct at the points. Style smooth, longer than the tube of the floret, terminating in two long purple ligulate stigmas, about the length of the style. Seeds furrowed, very hairy, crowned with a pencil-like pappus of purple feathered hairs.

Our drawing of this rare and beautiful plant was taken in October last, at the Nursery of Mr. Knight, in the King's Road. It is a native of North America; Pursh mentions it as growing in sandy woods and fields, in Virginia, Kentucky, and Carolina, " where it, and L. scariosa are known among the inhabitants of those countries by the name of Rattlesnake's Master. In case of being bit by this horrible animal, they bruise the bulbs of this plant, and apply it to the wound; while, at the same time, they make a decoction of it in milk, which is taken inwardly."

When grown in a rich light soil, this species will attain the height of 2 feet, or upwards; but it is very liable to perish in Winter, from its roots receiving too much moisture, the only reason we can account for its present scarcity, having been known in our gardens as far back as the year 1732. Its flowering so late in the season, is also much against its increase, as it seldom perfects its seed in this country; but this might be easily remedied, if a plant be grown in a pot, and placed in a greenhouse just as its flowers are opening, and, as they expand, to attach some pollen to the stigmas, there can be no doubt but they will seed freely; as we have found it to succeed well with L. scariosa, and L. pilosa. As soon as ripe, the seeds should be sown in pots of light sandy soil ; they will then come up strong in Spring, and some of them will flower the following Autumn.

1. Involucre with its front scales taken off, to show the naked dotted receptacle. 2. Floret enclosed by the pappus of the seed. 3. The same split open, to show the nerves. 4. Stamens spread open, showing the distinct filaments, and united anthers. 5. Style and Stigmas. 6. Seed terminated by its pencillike pappus. 



\title{
SCUTELLARIA orientalis.
}

\author{
Yellow-flowered Skull-cap.
}

Natural Order. Labiate. Brown prodr. 499.

Sect. II. B. Calyx bilabiatus.

SCUTELLARIA. Calyx bilabiatus, ebracteatus, labiis integris, superiore intùs fornicato, extùs apice gibbo; fructus clausus. Corolla ringens, galeâ subtridentatâ, labii inferioris laciniâ mediâ emarginatâ.

Herbæ $v$. Suffrutices. Flores axillares, solitarii $v$. terminales, spicati. Brown prodr. 507.

S. orientalis, foliis incisis subtus tomentosis, spicis rotundatotetragonis. Willden. sp. pl. 3. p. 171. Enum. supp. 42. Hort. Kew. ed. 2. v. 3. p. 426. Link enum. 2. p. 120. Botan. magaz. 2120.

Perennial. Stems of a woody texture at the base, spreading, ascendent, much branched; branches spreading, of a purple colour, pubescent. Leaves opposite, ovate or oblong, obtuse, incised or deeply toothed, with blunt rounded teeth, underneath clothed with a dense white tomentum. Petioles shorter than the leaves, pubescent. Spikes roundly 4-sided, from 2 to 4 inches in length. Bractes sessile, ovate, concave, pointed, much veined, villous. Pedicles short, villous, close-pressed to the stem. Calyx very small, 2-lipped, very hairy ; lips entire, the upper one forming a kind of cap, and enclosing the seeds. Corolla tubular, ringent, villous, of a yellow colour, the helmet tinged with red, lower lip reflexed on each side. Stamens 4, inserted in the tube, 2 rather longer than the others; filaments declining, slightly hairy at the 
base, and smooth at the points; anthers hairy. Style smooth, about the length of the stamens. Stigma a small simple point.

A pretty herbaceous perennial, which produces an abundance of flowers, continuing to bloom from July to October; and only requires to be planted in the open ground, in a rich light soil; but we believe it not to be a long lived plant, and must, consequently, be frequently renewed either by seeds or cuttings; if by the latter, they will strike root readily, taking off the young shoots and planting them under a common hand-glass in the open ground; but care must be taken not to let the glass remain on them too long, or they will be apt to damp; as soon as they begin to root, a little air must be given them, encreasing it by degrees, till the plants are well rooted; they may then be planted where they are to remain. If raised from seeds, they may either be sown in pots, or in the open ground; and the sooner they are transplanted where they are to remain the better, as they do not miss their removal when young, but when grown larger, they are likely to wither and not do so well; the same observation is suitable to most herbaceous plants.

A native of the Levant; of low stature, seldom attaining a foot in height, and, therefore, proper for the front of flower borders. Our drawing was taken at the Apothecaries' Company's Garden, at Chelsea, in August last.

1. Calyx, highly magnified, the upper part turned back, to show the 4 naked seeds. 2. Corolla spread open, to show the insertion of the filaments. 3. Stamen detached. 4. Style, and simple Stigma. 



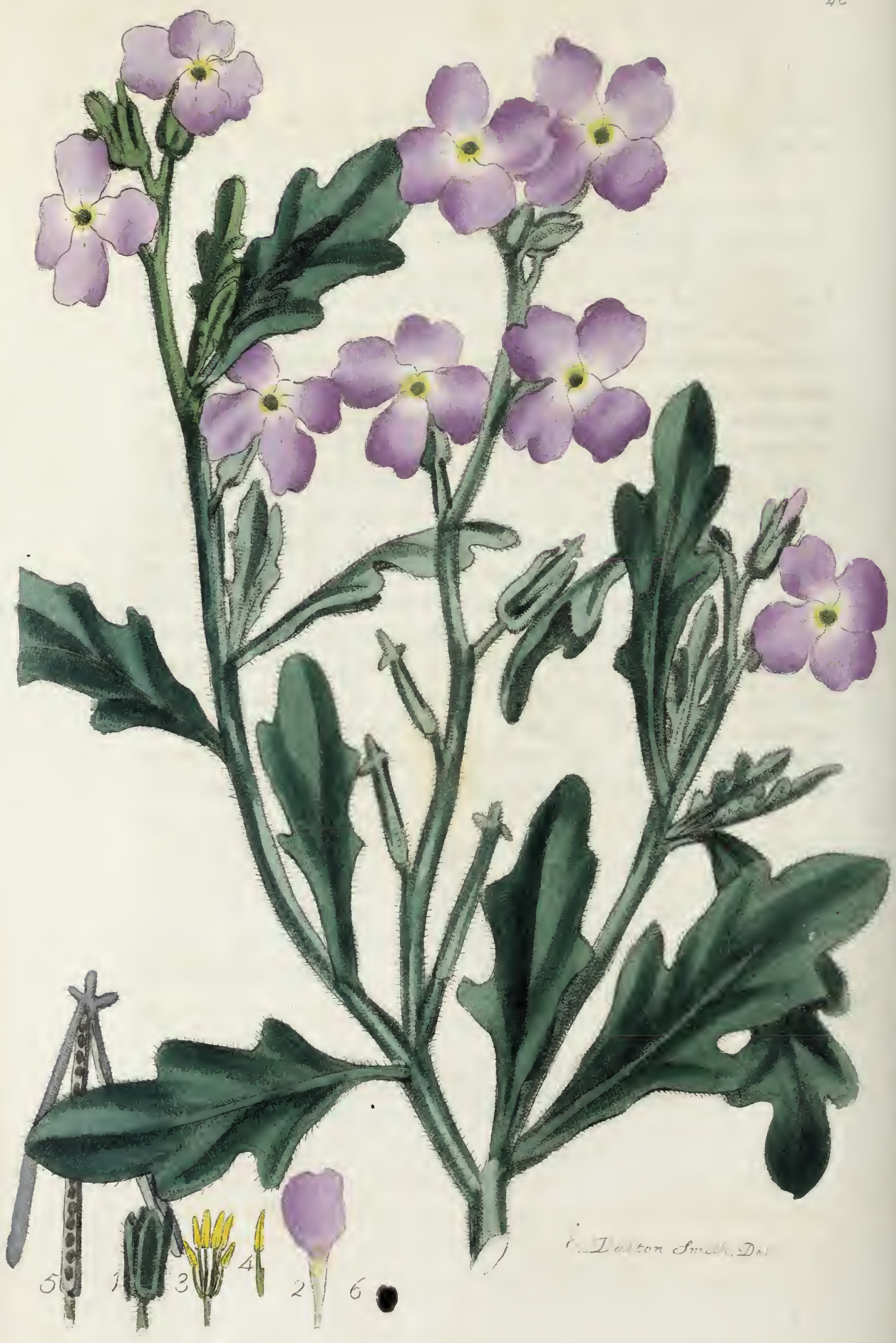




\title{
MATHIOLA tricuspidata.
}

\author{
Three-forked Stock.
}

Natural Order. Cruciferæ. DC. Reg. veg. syst. nat. v. 2. p. 139.

Subordo. I. PleURORHIZEE. DC. $p .146$.

Cotyledones planæ, accumbentes. Radicula lateralia. Semina compressa.

Tribus I. ARABIDEE seu Pleurorhizeæ Siliquosæ. Siliqua dehiscens, septo lineari seminibus plus minus latiore. Semina ovalia, compressa, sæpe marginata. Cotyledones planæ, accumbentes, septo parallelæ.

MATHIOL $A$. Calyx erectus, basi bisaccatus. Petala unguiculata, limbo patente obovato aut oblongo. Stamina libera, edentula, longiora subdilatata. Siliqua teres vel compressa, elongata, bilocularis, bivalvis, stigmate connivente bilobo, lobis dorso vel incrassatis vel cornigeris. Semina compressa, 1-serialia, sæpius marginata. Cotyledones planæ, accumbentes. Herbæ aut rarissimè suffrutices, erectæ aut diffusa, ramosa, fere omnes tomento stellato molli albida, interdum glandulis subpedicellatis scabra. Folia alterna, oblonga, integra aut dentato-sinuata. Racemi terminales. Pedicelli ebracteati. Flores purpurei aut albi aut sordidè purpurascentes, tristes, sapiùs odorati. DC. p. 162.

Sect. IV. ACINOTUM. Petalorum laminæ obovatæ obtusæ aut emarginatæ, lætè purpureæ aut albæ. Siliqua apice tricuspidata, stigmatum dorsis nempè in cornua exsertis. DC. p.175.

M. tricuspidata, caule suberecto ramoso, foliis sinuato-pinnatifidis, siliquæ cuspidibus 3 acutis subæqualibus. DC. loc. cit. Mathiola tricuspidata. Brown hort. kew. ed.2. v.4. p. 120. Hort. sub. lond. $14 \%$.

Cheiranthus tricuspidatus. Willden. sp. pl. 3. p. 523. Sibth. fl. grac. t. 639. Schkuhr. handb.2. p.250. t. 184.

Root anuual, slender. Stems much branched, spreading in various directions, cylindrical, attaining a foot, or 18 inches in height, thickly clothed with branching woolly hairs; branches flexuose, ascending. 
Leaves oblong, obtuse, slender at the base; those near the root repandly-dentate, or slightly sinuate; stem ones more divided, sinuately pinnatifid ; sinuses obtuse, tomentose. Racemes terminal, flexuose, many-flowered. Pedicles tom entose, about a line long, at first erect, afterwards spreading. Flowers of a bright lilac, light at the base. Calyx of 4 sepals, about 4 lines long, tomentose, swollen into 2 little pouches at the base. Petals 4, alternate with the sepals, limb obovate, or obcordate, at first of a pale lilac, afterwards becoming darker; claw slender, about the length of the calyx. Stamens 6, unequal; filaments 2, very short, and straight; 4 longer, with a small tooth on one side, running down in a wing to the base; anthers linear, 2-celled. Siliqua nearly round, tomentose. Stigma lengthening out into 3 points, or horns, the middle one erect, the others spreading.

The present genus was first established by Mr. Brown, in the second edition of the Hortus Kewensis, and contains all the different species of Stocks, which were before that time arranged with Cheiranthus, (or the Wall-flowers.) M. Decandolle enumerates 27 species, which he divides into 4 Sections, or Sub-genera. The present species belongs to his last Section, distinguished from the others by its horned stigma, and obovate petals ; it is a very pretty annual plant, native of the sandy shores of the Mediterranean, and of the South of Europe, growing, with us, to the height of a foot, or 18 inches, and requires no other treatment but to be sown early in Spring, in the open ground, in as light a soil as possible, and to be kept free from weeds. last.

Drawn at the Nursery of Mr. Colvill, in September

1. Calyx. 2. Petal. 3. Stamens, 4 long, and 2 short. 4. One detached, to show the small tooth in the middle of the filament, running down in a wing to the base. 5. Siliqua spread open, to show the seeds, terminated by 3 points, or horns. 6. Sced. 



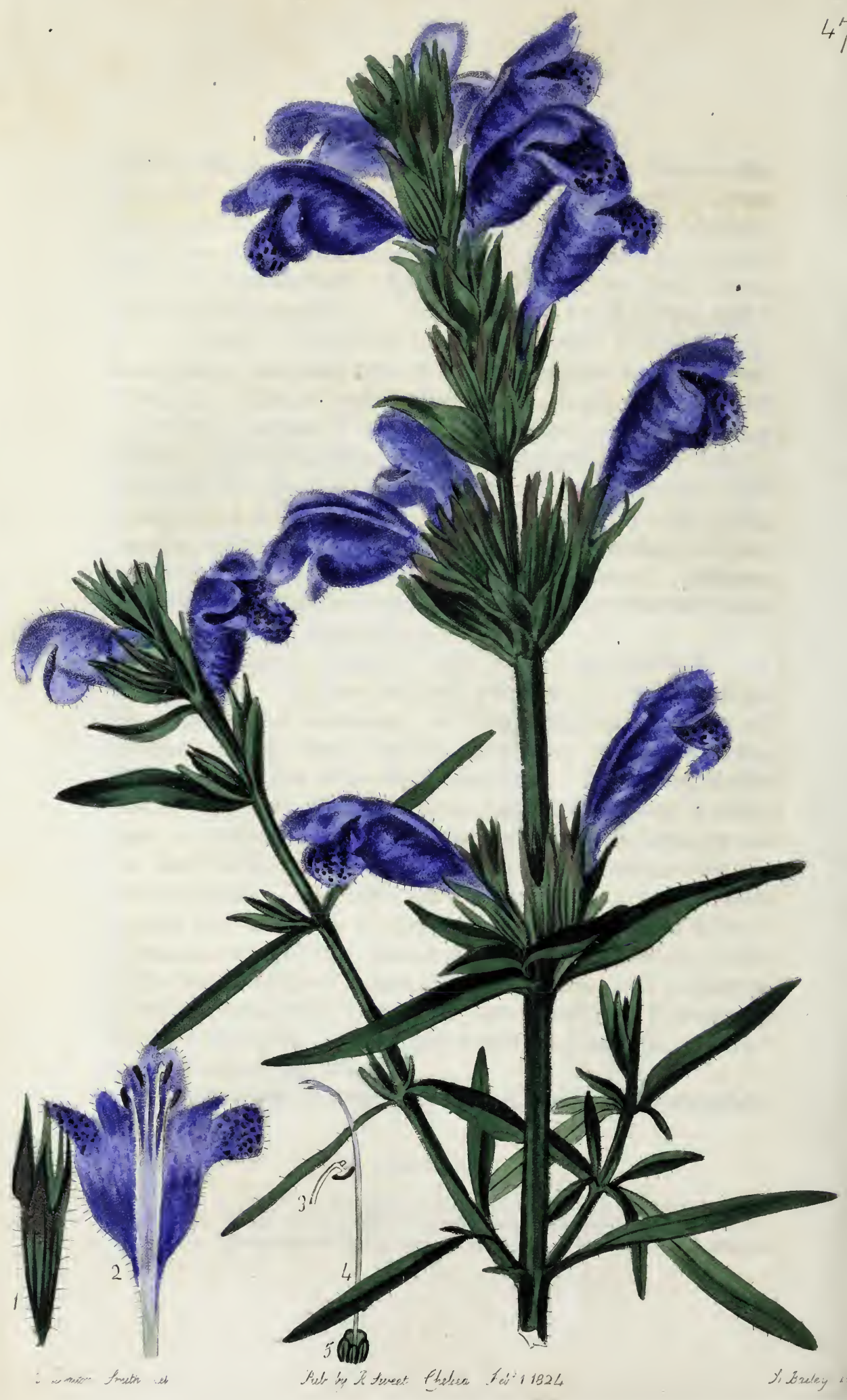




\section{DRACOCEPHALUM argunense.}

Fischer's Dragon's-head.

Natural Order. Labiate. Brown prodr. 499.

DRACOCEPHALUM. Supra fol. 38.

D. argunense, floribus verticillato-spicatis subcapitatis, foliis lineari-lanceolatis obtusis integerrimis margine scabris, bracteis elliptico-lanceolatis acuminatis.

Dracocephalum argunense. Fischer Mss. Link enum. 2. p. 118.

Perennial. Stems several from the same root, branching a little, obtusely 4-sided, pubescent, from a foot to 18 inches in height. Leaves linearly lanceolate, entire, bluntish, with rough edges, attenuated into a kind of footstalk at the base, smooth and glossy on the upper, and slightly pubescent on the lower side. Flowers in a whorled spike, terminated in a kind of head, of a bright blue colour. Bractes 4, at the base of each whorl, elliptically lanceolate, taper-pointed, entire. Pedicles short and flat, slightly pubescent. Calyx 5-cleft, striated with numerous shallow furrows; segments lanceolate, acute, of a purplish colour, upper one more than double the size of the others. Corolla tubular, inflated at the mouth, 2-lipped, hairy within and without; upper lip, or helmet, emarginate, concave, very hairy on both sides; lower lip 3-lobed; end lobe very broad, obcordate, sides doubled in, spotted inside with numerous small purple spots; side lobes small, rounded, sides reflexed. Stamens 4, inserted in the mouth, 2 a little longer than the others, declining; filaments bearded with long white hairs, 
particularly the upper ones, and terminating in a blunt point, the anthers attached below it; anthers. incumbent, also bearded. Style smooth and glossy. Stigma 2-cleft, ending in 2 unequal points. Seeds 4, rugged.

For the opportunity of giving a figure of this new and beautiful plant, we are obliged to Mr. William Anderson, the worthy Curator of the Garden belonging to the Apothecaries' Company, at Chelsea; a collection particularly rich in hardy herbaceous plants. The present species was raised from seeds, received by Mr. Anderson from Dr. Fischer. It is a native of Siberia, and thrives well in the open borders, flowering from July to October, and attaining the height of a foot, or 18 inches, according to the strength of the soil ; scarcely any plant can be better adapted for the borders of the flower garden; and as it spreads but little, it needs little room. Young cuttings of it, planted under hand-glasses in the open ground, the same as recommended for Scutellaria orientalis, will root readily; it may also be raised from seeds, which will ripen occasionally.

1. Calyx. 2. Corolla spread open, to show the insertion of the stamens. 3. Stamen detached, showing the hairy filament, and anther. 4. Style and Stigmas. 5. The 4 naked Seeds. 



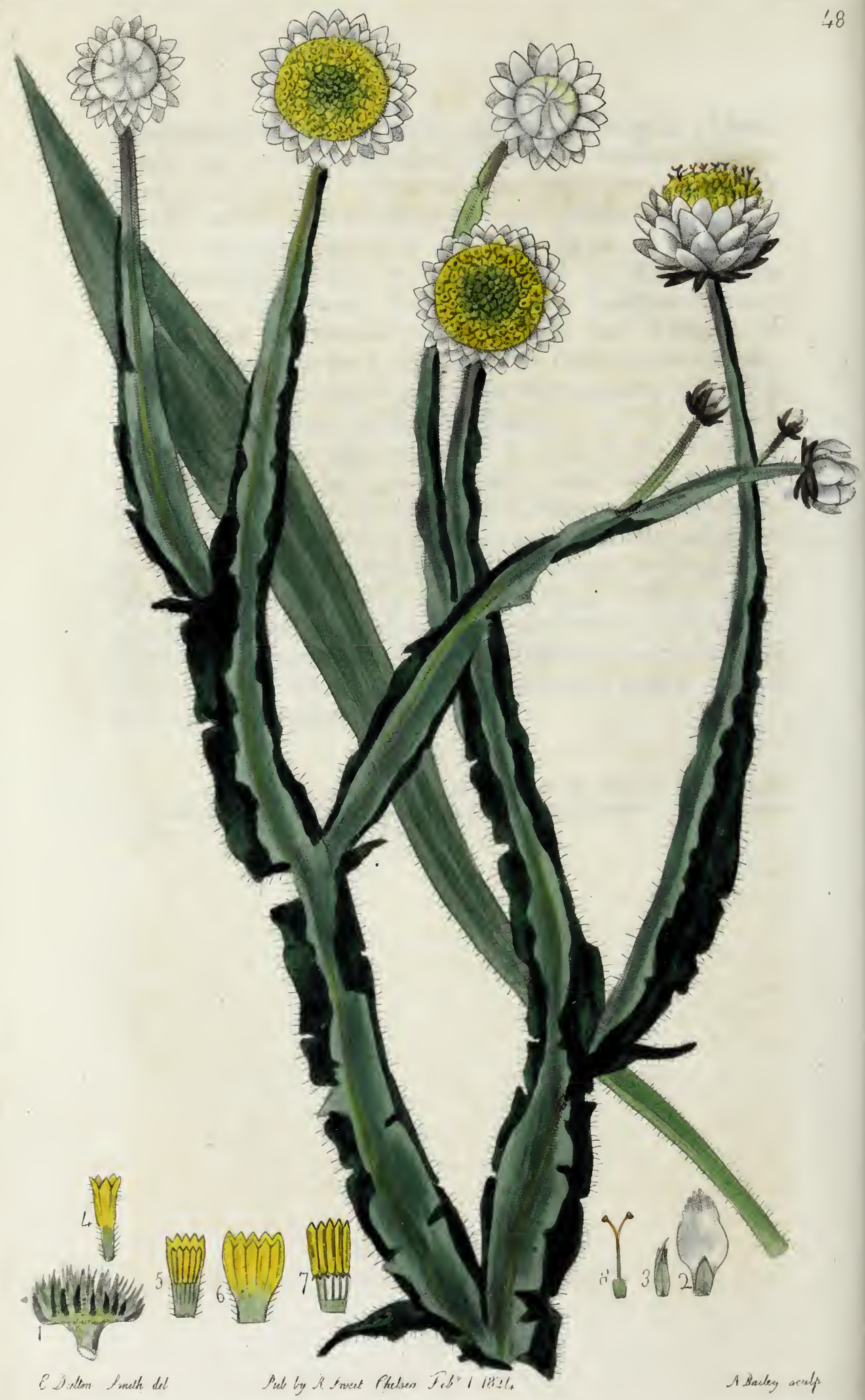




\title{
48
}

\section{AMMOBIUM alatum.}

\author{
Winged-stalked Ammobium.
}

Natural Order. Composite. Adanson fam. 2. 103.

Sect. II. CARDUACEE. Div. 5. Vernoniacece.

AMMOBIUM. Receptaculum paleis distinctis. Pappus; margo dentatus. Anthera basi bisetæ. Involucrum imbricatum, coloratum radians.

Herba erecta, tomentosa. Folia integerrima, radicalia lanceolata, basi attenuata; caulina minora, decurrentia. Caulis alatus, ramis unifloris. Involucra hemispharica laminis albis, intimis patulis radium abbreviatum efformantibus. Corollulæ uniformes, flava. Stigmata truncato-dilatata. Semina ancipitia. Receptaculum convexum. Brown in Botan. magaz. 2459.

Ammobium alatum. Brown loc. cit.

Stems from 18 inches to 2 feet in height, flexuose, much branched, 4-winged ; branches corymbose, erect, tomentose, each terminated with a single capitulum; wings more or less curled, or undulate. Leaves at the root stellately spreading, oblongly lanceolate, acute, tapering to the base, entire, tomentose; those on the stems short, lanceolate, taper-pointed, undulate, broad at the base, clasping the stem, and decurrent, or running down it in a leafy border, or wing. Peduncle erect, also winged. Involucre many-leaved, imbricate; scales white, scariose, oblong, blunt, more or less wrinkled, radiate when the flower is expanded. Receptacle chaffy. Chaff membranaceous, broadly lanceolate, slightly toothed near the point, strongly keeled at the back, mucronate. Rays none. Florets tubular, 5-cleft, clothed here and there with small glandular pellucid hairs. Stamens 5; filaments distinct; anthers connected, but distinct at the points, with 2 small bristle like spurs at the base of each. 
Style smooth, included in the tube. Stigmas 2, spreading, each terminated in a small truncated head. Seeds flat, sharp-edged, terminated by 2 very small teeth.

Our drawing of this curious and pretty perennial plant, was taken at the extensive and richly stocked Garden belonging to the Horticultural Society at Chiswick, in August last, where it was raised from seed received from New South Wales, sent by Mr. Charles Frazer, Corresponding Member of the Horticultural Society ; and we are informed by Joseph Sabine, Esq. that it is hardy, and grows well in a rich border, blossoming the whole Summer, and Autumn. “ It was discovered by Robert Brown, Esq. in 1804, growing plentifully near the shores of Port Hunter, in New South Wales, and named by him Ammobium, from its growing in sand." We would recommend its being planted in a south border; and, should the Winter be severe, to be occasionally covered with a little straw, or fern; but always leaving it uncovered in mild weather, that it might not rot. We believe most of the herbaceous plants from New South Wales, Van Diemen's Land, and New Zealand, would succeed well by this management; several that we have tried ourselves have succeeded very well.

We have often been surprized that the seeds of so few annual plants have, as yet, been introduced from New Holland, and also from the Cape of Good Hope, where so many pretty and interesting ones are growing wild in all directions ; those would be most desirable, as they would all prove quite hardy, requiring nothing but to be sown in the open ground.

1. The Chaffy Receptacle cut through the middle. 2. Scale of the Involucre. 3. Scale of the Chaff. 4. Floret of the Disk. 5. The same split open, to show the insertion of the Stamens. 6. The same divested of the Stamens. 7. Stamens, showing the united Anthers and distinct Filaments. 8. Seed, terminated by a Style, and 2 capitate Stigmas, all magnified, except the Receptacle. 



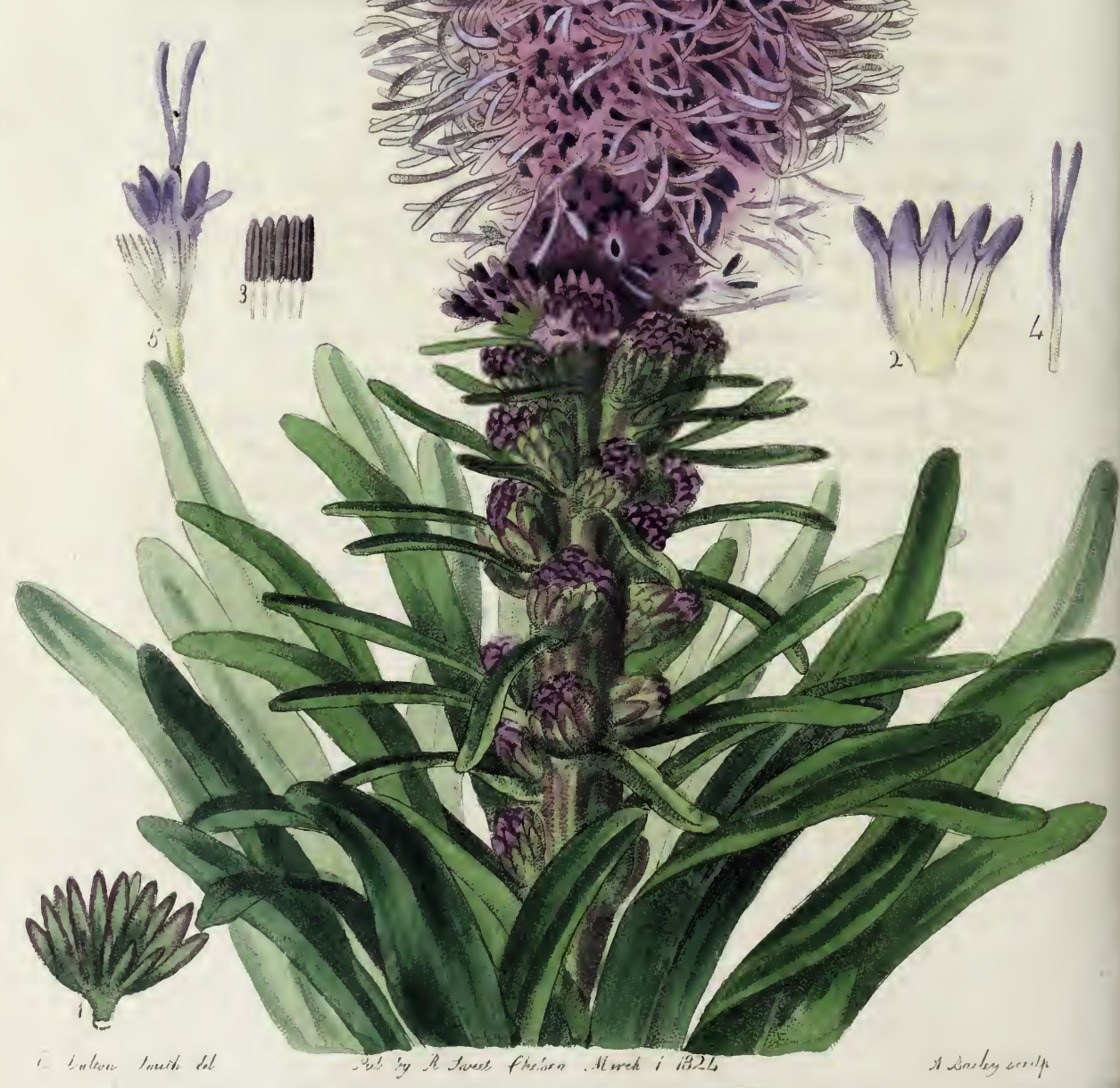




\title{
LIATRIS spicata.
}

\author{
Long-spiked Liatris.
}

Natural Order. Сомроsita. Adanson fam. 2.103.

Sect. II. CARDUACEA. Div. 5. Vernoniacea. LIATRIS. Supra fol. 44.

L. spicata, caule simplici elato, foliis linearibus glabris basi ciliatis nervosis et punctatis, spica longissima ; floribus sessilibus, squamis lineari-oblongis obtusis appressis. Pursh $\boldsymbol{F l}$. Amer. sept. v. 2. p. 507. sub. L. macrostachya.

Liatris spicata. Willden. $s p . p l$. 3. p. 1636. Botan. magaz. 1411. Pers. syn. 2. p. 403.

Liatris macrostachya. Mich. amer. 2. p. 91.

Serratula spicata. Andrews's reposit. 401.

Root tuberous, bulbiform, fleshy; from the base and sides of which proceed numerous fibres. Stems several, springing from the same root, from 1 to 4 feet high, erect, more than half composed of pith, very leafy, channelled, owing to the wings that run down the stem from one leaf to the next, smooth, green below, and purple upwards. Leaves sessile, at the root lanceolate, stem ones linear, smooth, with a fringed base, prominently veined and dotted with numerous small transparent dots, bluntish. Flowers purple, crowded in a long close spike, sessile. Involucre many-leaved, imbricate ; scales linearly oblong, obtuse, close pressed, with a thin membranaceous margin. Receptacle naked, slightly convex, punctured. Florets from 10 to 20, tubular, 5-cleft, tube about the length of the pappus ; laciniæ oblong, bluntish, about half the length of the tube. Anthers 5, connected into a tube, about the length of the floret. Style about as long as the anthers, where it divides into 2 long blunt stigmas of a lilac 
colour, some of which are as long again as the floret. Seeds channelled, very hairy. Pappus composed of numerous feathered hairs.

This very handsome Autumn-flowering species will, in a rich light soil, sometimes attain the height of 3 or 4 feet; in poorer soil it scarcely exceeds a foot, or 18 inches. It is one of the most desirable plants with which we are acquainted, for the borders of the flower garden, as it is quite hardy, and is in bloom from August to October; the only danger of its not succeeding is, if it be planted in a damp situation, as its fleshy roots are very liable to perish with too much moisture; after flowering, the roots sometimes raise themselves considerably above the earth ; in that case, they should be covered with a little dry mould. The best time for transplanting them, is late in Autumn, when they are dormant, or very early in Spring; and if in a dry situation, the roots, if very large, may be parted; they may also be raised from seeds, which should be sown in pots as soon as ripe, and soon after they are come up, may be transplanted in the open ground, where they will soon become flowering plants. Drawn at the Nursery of Mr. Colvill, King's Road, Chelsea, in September.

3. Capitulum split through the middle, to show the naked dotted receptacle. 2. Floret spread open, to show the nerves. 3. Stamens spread open, showing the distinct filaments, and united anthers. 4. Style terminated by its 2 blunt spreading Stigmas. 5. Seed, showing its feathered pappus. 


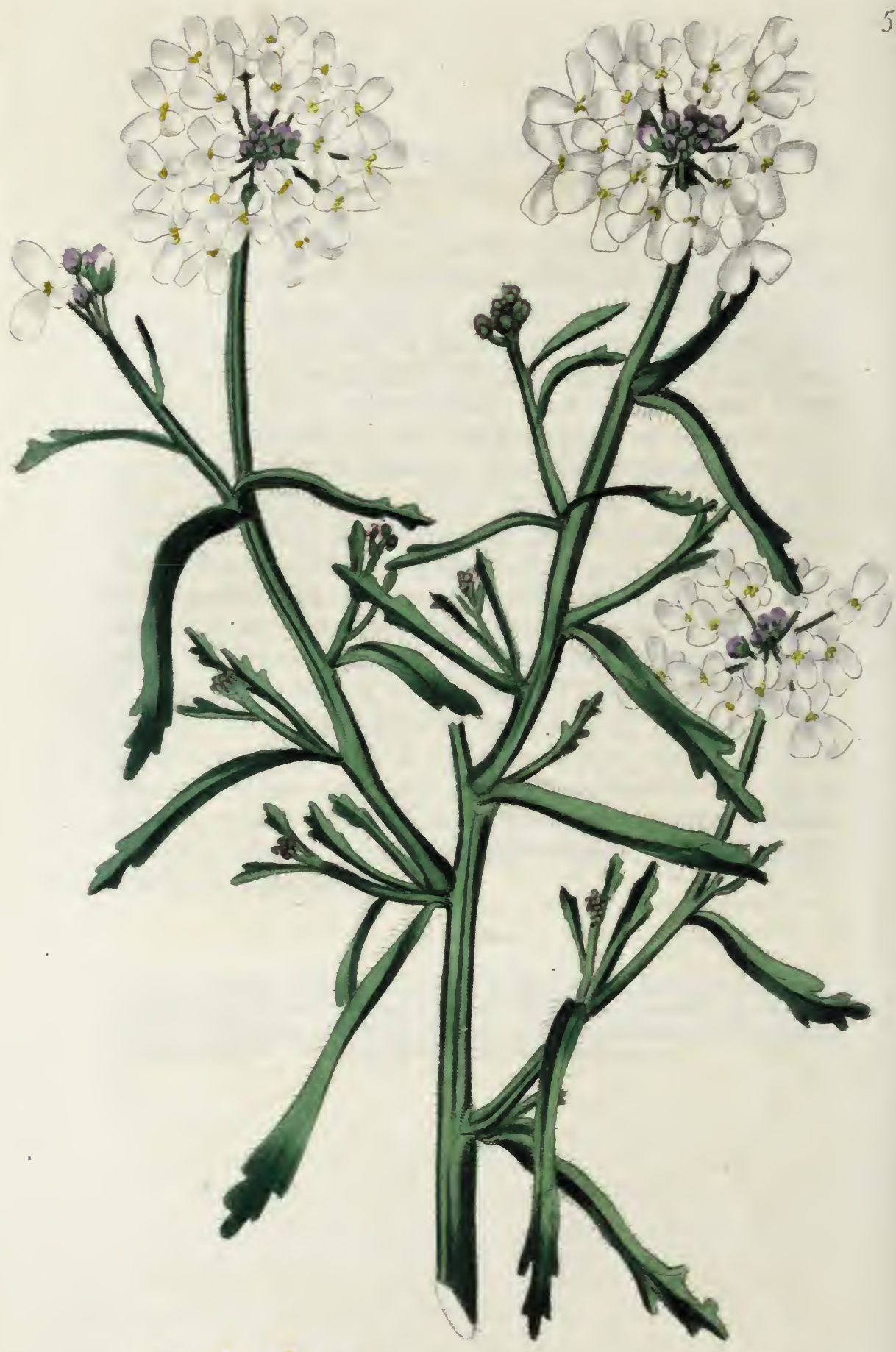

(4)

i Jater tom dé 


\title{
IBERIS odorata.
}

\author{
Sweet-scented Candy-tuft.
}

Natural Order. Crucifere. DC. Reg. veg. syst. nat. v. 2. p. 139.

Subordo I. PleURoRhizeA. DC. $p .146$.

Tribus III. THLASPIDE E seu Pleurorhizeæ Angustiseptæ. Silicula bilocularis, bivalvis, septo angustissimo lineari, valvis carinatis aut navicularibus. Semina ovalia, compressa, sæpè marginata. Cotyledones planæ, accumbentes. DC. p. 372.

IBERIS. Calyx basi æqualis. Petala 4, inæqualia, 2 exteriora majora. Stamina libera, edentula. Silicula valvis carinatis navicularibus depressissima, basi ovata, apice valvis nempè in lobulos productis emarginata, stylo persistente filiformi apiculata, septo interdùm bipartibili angustissimo, loculis latere interno axi adnatis, 1-spermis. Semina ovata, pendula. Radicula ad latus embryonis exterius. Cotyledones interius adscendentes, accumbentes. Herbæ aut Suffrutices. Caules teretes, sapiùs glabri, interdum subcarnosi. Folia alterna, linearia aut obovata, integra, dentata aut pinnatifida, interdùm crassiuscula. Racemi nunc elongati, nunc per anthesin corymbosi postè elongati, nunc imò post anthesin corymboso-umbellati. Pedicelli ebracteati. Flores albi aut purpurascentes (nunquam lutei), exteriores corymbi magis irregulares, interiores subregulares. DC. syst. p. 393.

I. odorata, herbacea glabra, foliis linearibus dentatis basi ciliatis apice dilatatis, siliculis subrotundis; emarginaturæ lobis acutis patulis stylo brevioribus. DC. syst. p. 400.

Iberis odorata. Lin. sp. 906. Mill. dict. n. 4. Willd. sp. pl. 3. p. 437. Pers. syn.2. p. 187. Hort. sub. lond.p. 144. DC. prodr. 1. p. 180.

$\boldsymbol{R}$ oot annual, slender. Stem erect, bluntly angular, more or less branched, densely clothed with short white hairs; branches erect, furrowed. Leaves linear, succulent, slender, and fringed at the base, widened, 02 
and blunt at the point; lower ones pinnatifid, segments blunt, spreading; upper ones longer and narrower, thinly toothed near the point with short blunt teeth. Peduncle obsoletely 4-cornered, and furrowed with numerous channels, very hairy. Flowers corymbose, white, sweet-scented, very little lengthened when in fruit. Pedicles slender, a little flattened, thickest at the base, and gradually tapering upwards; lower ones longest. Calyx of 4 short sepals, which are obovate, concave, their points bent inwards, with brownish red membranaceous margins. Petals 4, unequal, particularly on the outer flowers; on the inner ones becoming nearly equal. Style a little longer than the stamens. Silicle nearly round, covered with small pellucid glands, and terminated in 2 spreading sharppointed lobes.

Our drawing of this pretty and fragrant annual plant, was taken this Summer at the Nursery of Mr. Colvill, where it was cultivated in the open ground, and continued to flower all the Summer; it is allied to I. pinnata, but differs in its stem leaves being only toothed, and its acute lobed pods; it is also related to I. amara, in its flowers, but differs considerably in its leaves and pods. A native of Crete; and only requires to be sown in the open borders, and to be kept free from weeds. Our specimens grew to the height of a foot, and ripened plenty of seeds, which should be sown in March, or April; others may be sown later in Summer, they will then continue to flower late in the season.

1. Calyx. 2. One of the large petals, and 1 of the small ones. 3. Stamens. 4. Stamen detached. 5. Germen, showing its acute lobes, and terminated with the style, and capitate stigma. 6. Silicle, or pod. 



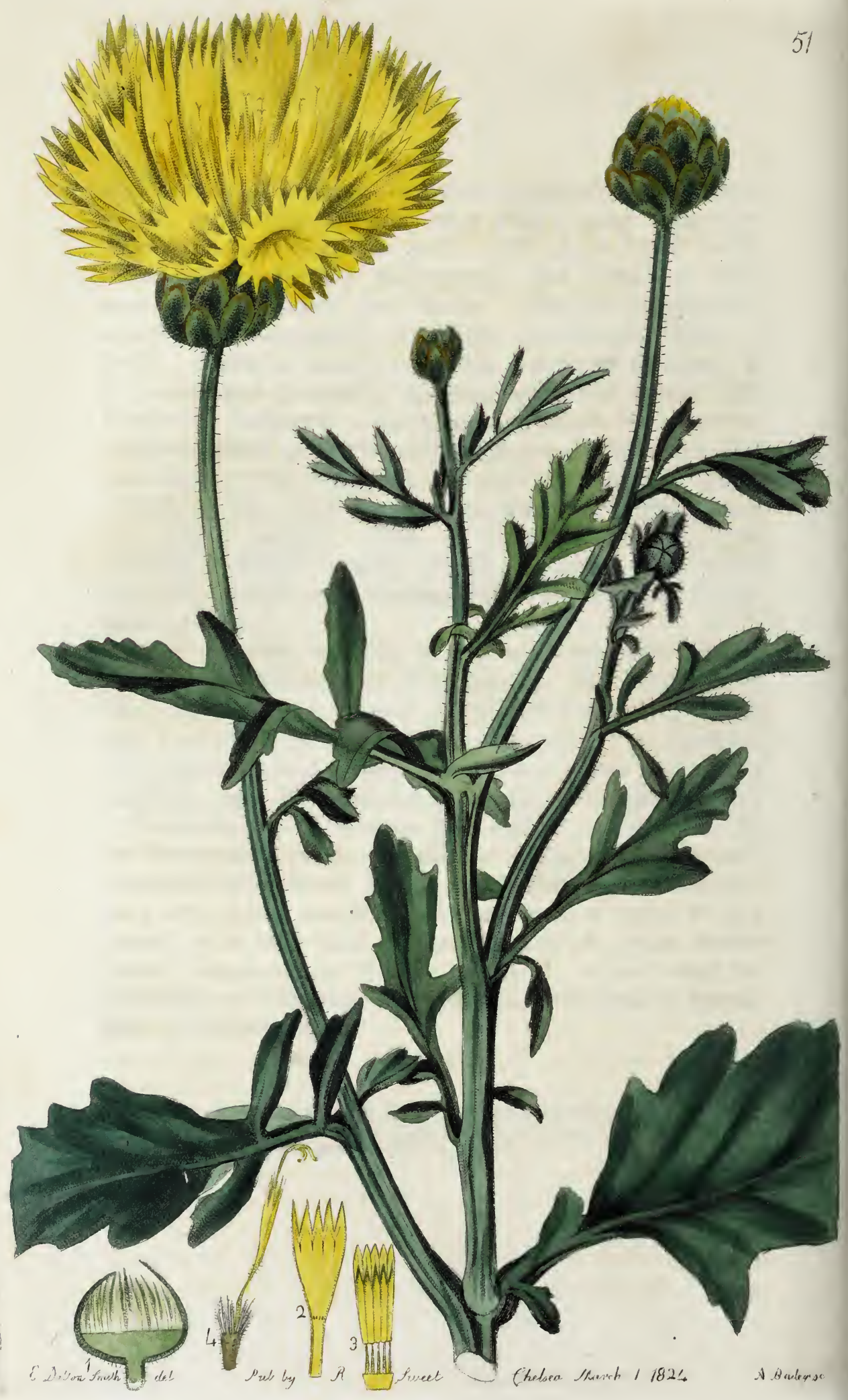




\title{
CENTAUREA suaveolens.
}

\author{
Yellow sweet Sultan, or Centaury.
}

Natural Order. Composite. Adanson fam. 2. 103.

Sect. II. CARDUACEA.

CENTAUREA. Receptaculum setosum. Pappus simplex. Corolla radii infundibuliformes, longiores, irregulares.

Sect. I. (Centaurea Juss.) Flores centrales hermaphroditi, marginales neutri. Involucri squamæ inarmes simplices. Folia simplicia aut pinnata.

C. suaveolens, involucris inermibus glabris, squamis subrotundoovatis obtusiusculis apice sphacelatis, foliis lyrato-pinnatifidis. Willden. sp. pl. 3. p. 2279.

Centaurea suaveolens. Pers. syn.2. p.481. Hort. Kew. ed.2. v. 5. p. 144.

Annual. Stem erect, much branched, from a foot to 18 inches in height; branches angular, pubescent. Leaves lyrately pinnatifid, when young pubescent, the pubescence gradually wearing off; lower ones ovate or elliptic, more or less sharply toothed; upper ones oblong, or lanceolate, more pointed; segments bluntish. Peduncles terminal, 1-flowered, many angled, pubescent. Flowers large, golden yellow. Involucre manyleaved, imbricate; scales roundly-ovate, blunt, and terminated with a brown point, the upper ones sphacelate, smooth, or slightly pubescent. Receptacle flat, setose. Marginal florets very large, barren, tubular, terminated with from 18 to 24 sharp pointed teeth. Florets of the disk fertile, tubular, and terminated in $\checkmark$ loug pointed teeth, furnished both with stamens and pistil. Stamens 5; filaments distinct; anthers con- 
nected; pollen bright yellow. Style smooth. Stigma terminated in a long point. Seeds densely hairy, crowned with a feathered pappus.

This very handsome and delightfully fragrant annual, is particularly well adapted for ornamenting the flower borders in Summer; it is rather more tender than the more common Sweet Sultan, or C. moschata, and thrives best in a warm dryish situation; if sown in the open ground, it should be in a border of light rich earth, and as much exposed to the sun as possible; if the Summer proves favourable, the plants will succeed very well, growing to the height of a foot, or 18 inches, and continuing to bloom nearly all the Summer. They may also be sown in pots, in a hothouse, or green-house, or on a hot-bed that is often appropriated to the raising of rather tender annuals ; from thence they may be transplanted into the open ground; but this must be done before they get too large, or they will not be likely to do so well; when transplanted, they must be attended daily with water, should the weather prove dry and warm.

This plant, like many others, seldom produces seeds in any abundance; this is owing to the pollen not coming in contact with the stigmas; but is easily remedied by touching the stigmas of one flower with the pollen of another, by putting the two flowers together, and tapping the heads with the finger; this must be done when the sun is on them, as the pollen is then perfect.

Our drawing was taken at the Nursery of Mr. Colvill, last Summer.

1. Receptacle cut in two, to show the chaff. 2. Floret of the disk spread open. 3. Stamens spread open, showing the united anthers, and distinct filaments. 4. Seed crowned with a feathered pappus, and withered floret. 



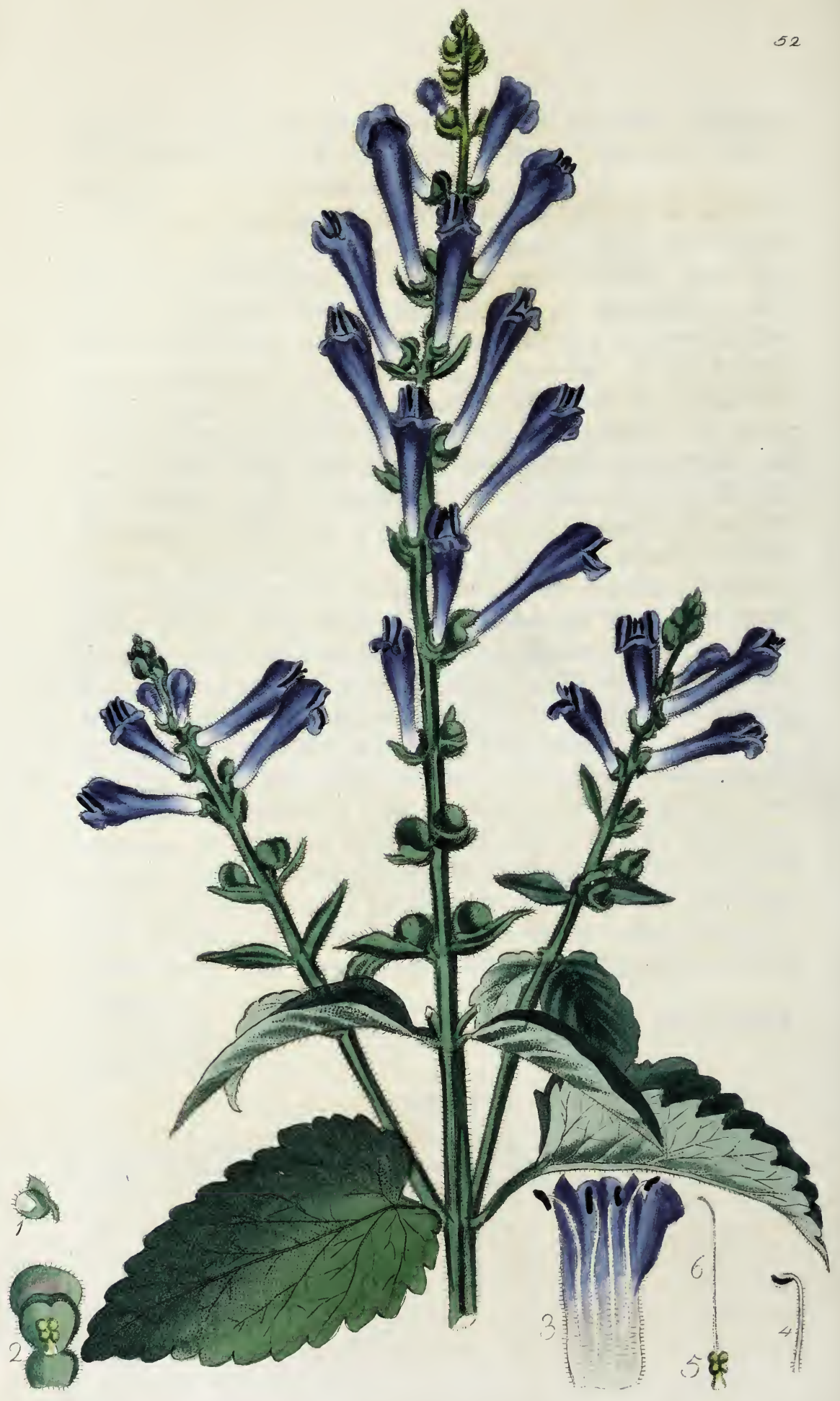

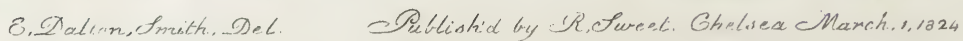




\title{
SCUTELLARIA Columnæ.
}

\author{
Columna's Skull-cap.
}

Natural Order. Labiate. Brown prodr. 499.

SCUTELLARIA. Supra fol. 45.

S. Columne, foliis oblongis cordatis serratis pubescentibus, spicis elongatis secundis, bracteis petiolatis ovatis calyce brevioribus. Willden. sp. pl. 3. p. 175.

Scutellaria Columnæ. Pers. syn. 2. p. 136. Hort. sub. lond. p. 135. All. pedem. n. 145. t. 84. f. 2. Column. ecphr. 1. p. 187. t. 189.

Perennial. Stems ascending, about 18 inches high, 4-sided, branching in all directions; branches bluntly quadrangular, clothed with a short dense pubescence. Leaves opposite, oblongly cordate, bluntly serrate, terminating in a bluntish point, rugose, pubescent on both sides. Petioles shorter than the leaves, channelled on the upper side, and convex on the lower, pubescent. Flower spikes long, the flowers in pairs, purple, and leaning to one side. Bractes on a very short footstalk, ovate, concave, pointed and ciliate, about the length of the calyx. Pedicles shorter than the bractes, villous. Calyx 2-lipped, entire, villous, enclosing the seeds, the upper lip forming a kind of cap. Corolla tubular, ringent, villous, helmet 3-lobed, upper lobe round, emarginate, side ones small, acute; lower lip emarginate, its sides a little reflected. Stamers 4, inserted in the tube, 2 longer than the others; filaments declining, very hairy; anthers incumbent, fringed. Style smooth, shorter than the stamens. 
Stigma a small simple point. Seeds 4, naked, smooth and shining, enclosed in the calyx.

Our drawing of this beautiful species of Scutellaria was taken at the Garden belonging to the Apothecaries' Company, at Chelsea, last Summer, where it grew to the height of about 18 inches, and continued to flower all the latter part of Summer. It is a very handsome plant, and its long spikes of purple flowers all leaning to one side, make an elegant appearance; like most of the other species of the genus, the stem is suffrutescent at the base, and from thence branches in various directions.

It succeeds well in the open ground, and prefers a rich light soil; it may be increased by dividing it at the root, or young cuttings planted under hand-glasses, in the open ground, will soon strike root, managing them, as was before directed in a former Number, under S. orientalis; it may also be increased by seeds, which sometimes ripen plentifully.

1. Calyx. 2. The same highly magnified, with the upper part turned back, to show the 4 naked seeds. 3. Corolla spread open, to show the insertion of the stamens. 4. Stamen detached. 5. The 4 naked Seeds. 6. Style. 


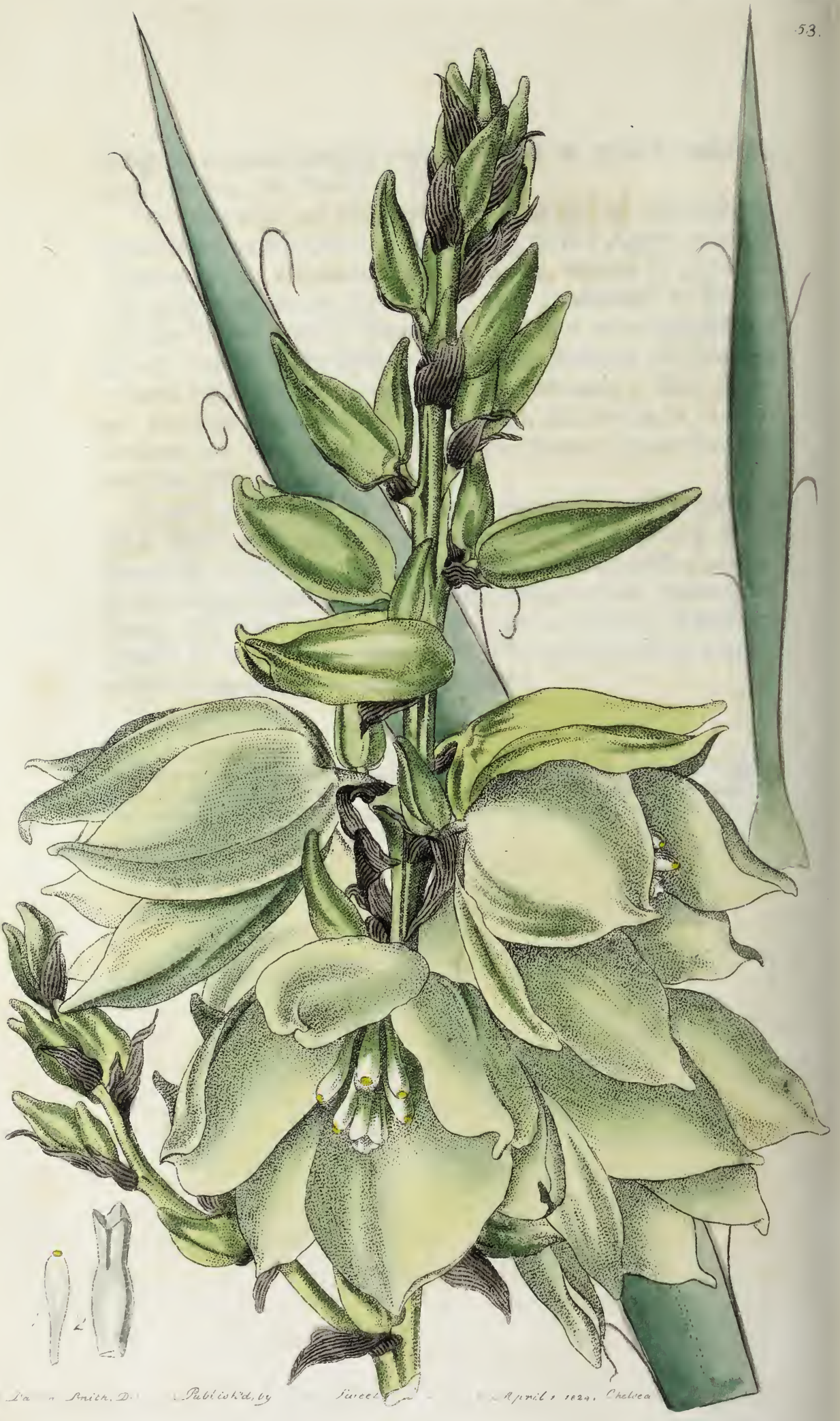




\title{
YUCCA glaucescens.
}

\author{
Glaucescent Adams Needle.
}

Natural Order. Tulipaces. Kunth Synops. 1. p. 292.

YUCCA. Perianthium campanulatum, laciniis rectis non nectariferis. Stamina filamentis supernè crassioribus; antheris minimis. Stylus 0; stigma sessile. Capsula oblonga, obtuse 3-gona ; semina plana. Caulis subnullus aut caudice assurgente fruticosus; folia confertia terminalia, ensiformia apice spinoso; flores spicati aut paniculati, terminales, bispathacei. Juss. gen. 49.

Y. glaucescens, foliis lineari-lanceolatis integerrimis concavis glaucescentibus strictis; margine rarissime filamentosis, petalis interioribus sesquilatioribus, caule erecto ramoso.

Yucca glaucescens. Haworth supp. plant. succ. p. 35.

A stemless species. Leaves several, spreading all round, middle ones upright, from 12 to 18 inches long, and 1 broad; linearly-lanceolate, straight, rigid, tapering at both ends, concave, particularly towards the point, which terminates in a sharp horny spine, of a dull glaucous colour; margin entire, with here and there a slender white filiferous thread, from 3 lines to 2 inches in length, a little twisted. Flower-stem from 3 to 4 feet in height, much branched towards the point; branches short, thickly clothed with flowers, angular, channelled, densely covered with a short white down. Flowers generally in pairs, the terminal ones solitary, of a greenish white, tinged with yellow. Bractes sphacelate, membranaceous, sheathing at the base, ovately lanceolate, concave, acute, of a grey 
brown, streaked with numerous darker lines. Peduncles short, cylindrical, a little bent when in flower, downy. Perianthium divided into 6 segments, nearly to the base, campanulately spreading; segments thick and succulent, the 3 inner ones half as broad again as the outer ones. Stamens 6, inserted in the base of the perianthium; filaments gradually thickening upwards, a little longer than the germen; anthers small in proportion, sagittate, attached at the base, bluntpointed. Germen superior, bluntly 3-sided. Style none. Stigmas 3, sessile, channelled inwards, with retuse points.

This plant is a native of North America, and was introduced by the late Mr. John Lyons, from whom Mr. Colvill purchased the plants from which our drawing was taken. Mr. T. Nuttall, in his GENERA of North American Plants, mentions a species of this genus, discovered by Mr. Lyons, nearly allied to Y. filamentosa, but much narrower leaved, and known by the name of Y. angustifolia by the gardeners around London, this is probably the species meant. It is a fine stately perennial plant when in flower; in rich soil attaining the height of 3 or 4 feet ; several plants flowered at Mr. Colvill's Nursery, last Summer, and continued in bloom from the beginning of August till the middle of October. It is quite hardy, will succeed well in any common garden soil, and may be increased abundantly by the suckers from the roots.

1. Stamen, showing its large thickened filament, and small anther. 2. Germen, terminated by its 3 sessile retuse stigmas. 



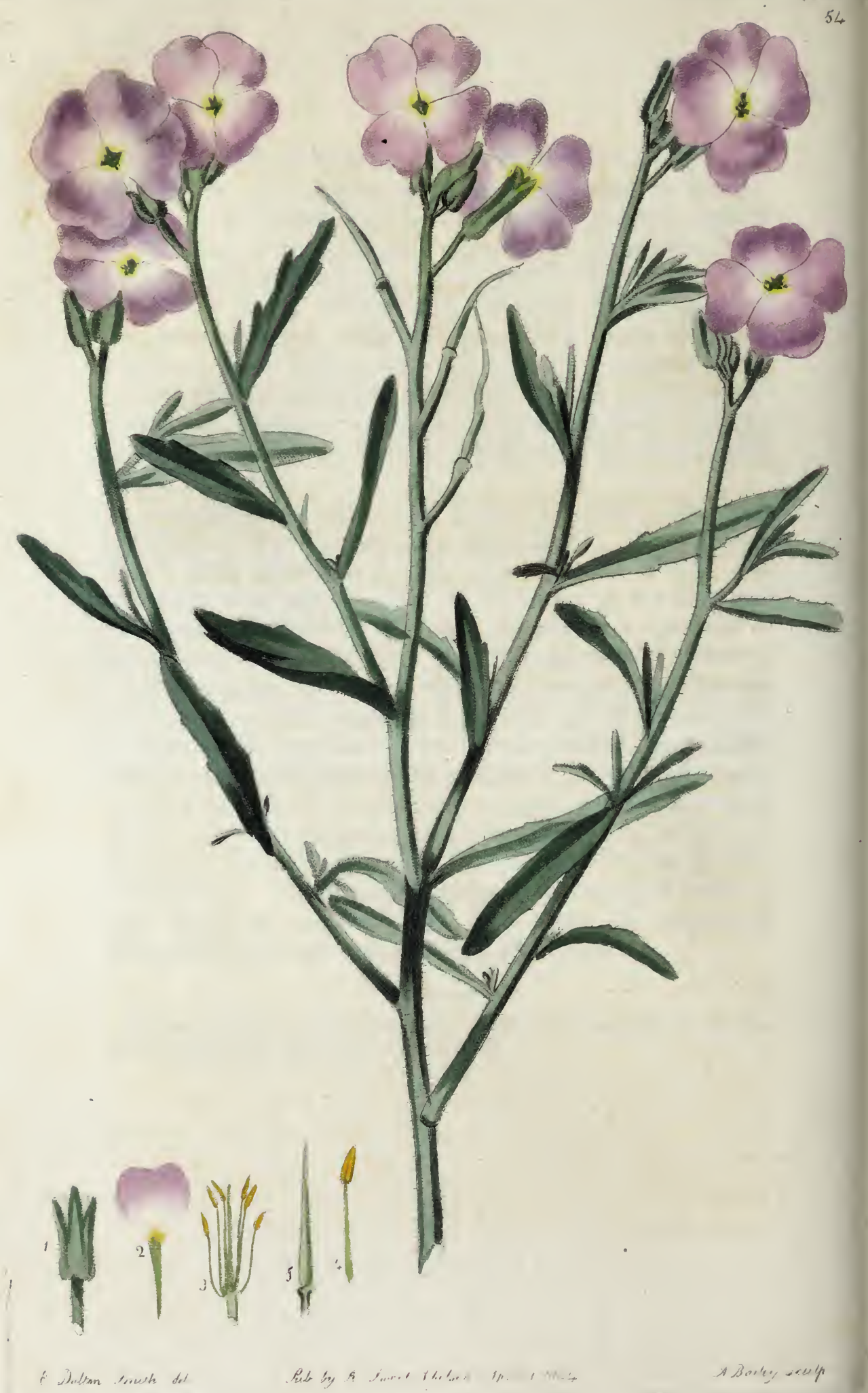




\title{
54
}

\section{MALCOMIA littorea.}

\author{
Tomentose Malcomia.
}

Natural Order. Crucifera. DC. reg. veg. syst. nat. ข. 2. p. 139.

MALCOMIA. Supra fol. 40.

M. littorea, caule multiplici erecto, foliis lanceolato-linearibus subintegris, tomento brevi canis, pedicellis calycis longitudine, siliquis incanis. DC. loc. cit. p. 443.

Malcomia littorea. Hort. Kew. ed. 2. v. 4. p. 121. Hort. sub. lond. 147.

Malcolmia littorea. Link enum. 2. p. 167.

Cheiranthus littoreus. Willden.sp.pl.3. p.521.

Hesperis littorea. Lam. dict. 3. p. 322.

Biennial. Stems several from the same root, simple, or sometimes branched, from 6 inches to a foot in height, upright, or slightly spreading, cylindrical, thickly clothed with a short white close-pressed tomentum, as are the leaves, peduncles, and calyx. Leaves lanceolately linear, blunt, attenuated to the base, entire, or distantly toothed. Racemes severalflowered, terminal, erect, without bractes. Pedicles slender, about the length of the calyx. Calyx of 4 sepals, connivent, 2-gibbous at the base; sepals linear, concave, bluntish, every other one largest. Petals 4, unguiculate, the unguis a little longer than the calyx; lamina obovate, or obcordate, emarginate, of a bright lilac, lighter at the base. Stamens 6 , inserted in the receptacle, 4 long, and 2 short ; filaments smooth, attached to the anthers a little above 
their base; anthers oblique, 2-celled, opening by the sides. Pod cylindrical, tomentose, terminated by an acute stigma.

This pretty plant is a hardy biennial, or by sowing the seeds early in Spring it might be treated as an annual; the best method is to sow the seeds in Autumn, the plants will then get strong, and flower early in Summer, and ripen plenty of seeds; when sown in Spring, they will not flower till the Autumn; and if the Summer should prove cold or wet, they will scarcely ripen their seeds at all.

Our drawing was taken from some plants at the Nursery of Mr. Colvill, where they were raised from seeds sown in the month of March; these began flowering in September, and continued in full bloom till the end of November, but the weather being generally wet at that season, they ripened no seeds.

1. Calyx. 2. Petal, showing its long slender unguis. 3. Stamens, 4 long, and 2 short, with the siliqua growing up through the middle of them. 4. Stamen detached, magnified. 5. Siliqua, terminated with its acute stigma. 



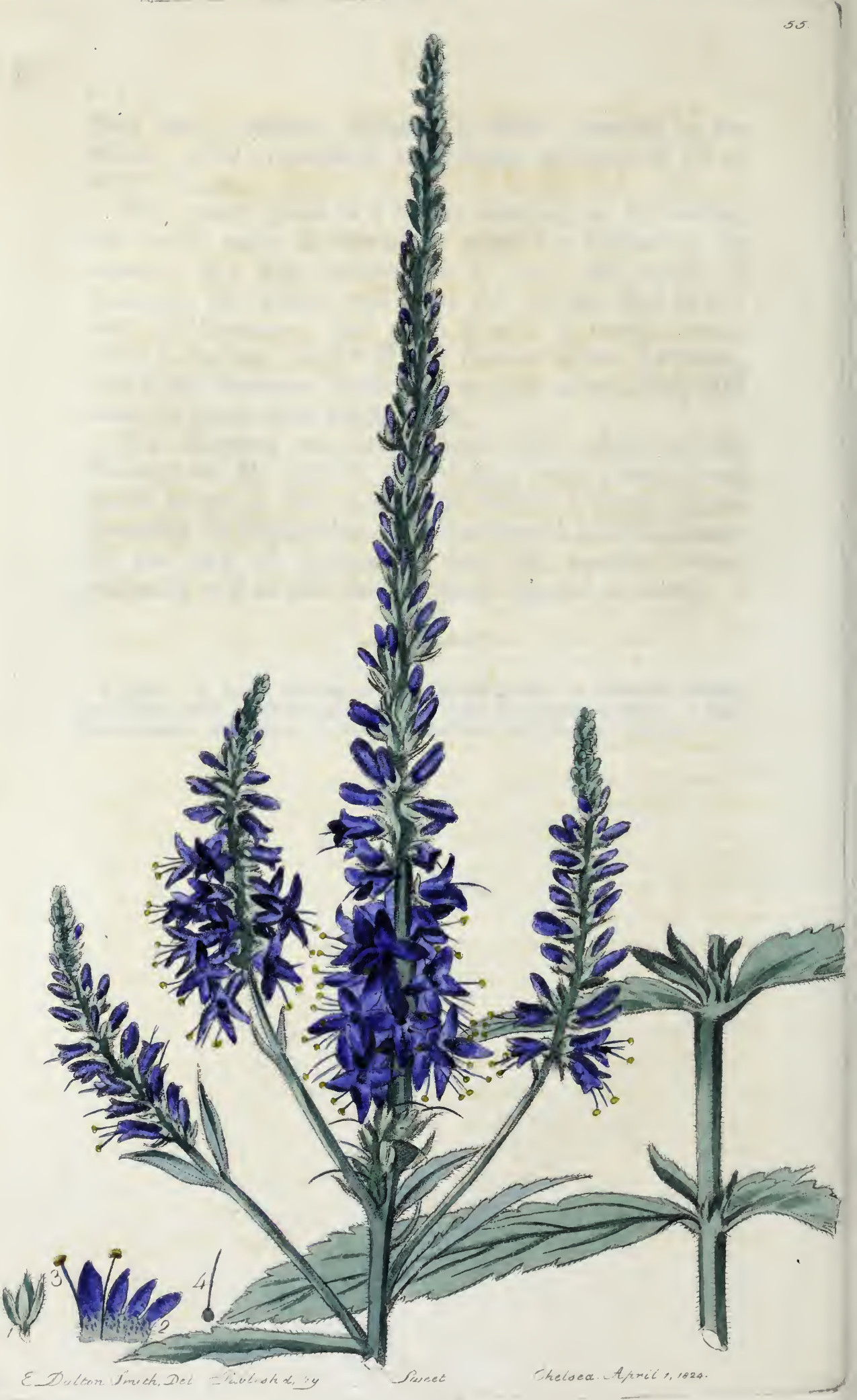




\title{
55
}

\section{VERONICA neglecta.}

\author{
Canescent Speedwell.
}

Natural Order. Scrophularine. Brown prodr. 433. Sect. 1. Stamina duo antherifera. Capsula bilocularis. VERONICA. Supra fol. 23.

V. neglecta, spicis terminalibus cano-pubescentibus, foliis serratis cauleque canescenti-tomentosis; radicalibus petiolatis oblongis obtusis; caulinis oppositis alternisve lanceolatis utrinque attenuatis basi integerrimis.

Veronica neglecta. Vahl. Willd.'enum.v. 1. p. 15. Rom. et Schult. syst.1. p.92. Sweet hort. sub. lond. p. 4.

Veronica canescens. Schrad. ver. 19. Link enum. 1. p. 21.

Root perennial. Stems prostrate at the base, then ascending, afterwards erect, thickly clothed with a white tomentum. Leaves canescent, serrate, but entire at the base; lower ones with long foot-stalks, oblong, bluntish; stem leaves opposite, lanceolate, pointed at both ends, upper ones alternate, those next the flowers nearly entire. Spikes several, terminal, the middle one much the longest, often a foot in length, hoary. Bractes subulate, lower ones a little longer than the flowers, upper ones about the length of the calyx, canescent, as are the pedicles and calyx. Pedicles very short. Calyx 4-parted, 2 lower segments deeply divided, subulately linear, nearly twice the length of the upper ones, which are ovate and blunt. Corolla subrotate; tube shorter than the calyx; limb 4-parted, unequal, spreading, of a bright blue colour; segments entire, some lanceolate, acute, others ovate, and blunt. Stamens 2. Filaments longer than the 
petals. Anthers incumbent, 2-celled, bursting in front to discharge the pollen. Germen woolly. Style smooth and shining, purple, about the length of the stamens. Stigma a simple blunt point, darker than the style.

Our drawing of this perennial plant, was taken at the Nursery of Mr. Colvill, where it continues in bloom the greater part of the Summer, and is quite hardy, requiring only to be planted in the open flower borders. In a rich soil, it often attains to the height of 18 inches ; in poorer soil, or in pots, it scarcely exceeds a foot; it is a very proper plant for the adorning of rock-work, and will also thrive in a shady situation. It is nearly related to $V$. incana, with which it has been often confounded, when in a weak state, but the leaves of that are generally entire; when growing strong, it is sometimes confounded with V.australis, but the leaves of that are thicker, and much deeper notched. It is readily increased by dividing it at the root; or it may be raised from seeds, which ripen in abundance.

1. Calyx, showing its unequal lacinix. 2. Corolla spread open, to show the unequal segments. 3. The 2 stamens inserted in the base of the corolla. 4. Germen terminated by the Style and small Stigma. 



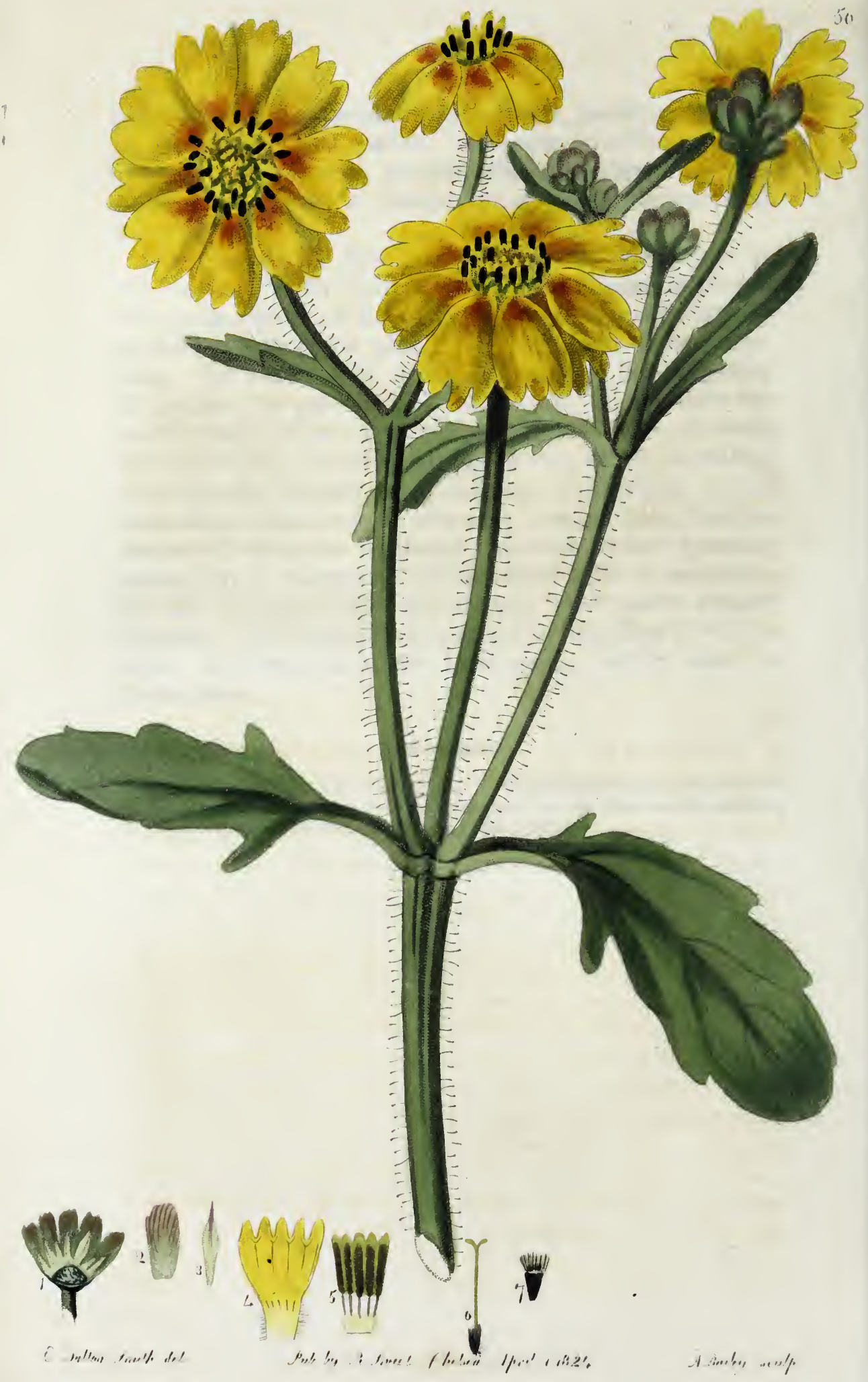




\section{GALINSOGEA trilobata.}

Three-lobed Galinsogea.

Natural Order. Composite. Adanson fam. 2. 103.

Sect. V. HELIANTHEA. Kunth Synops. tom. 2. p. 463.

GALINSOGE $A$. Involucrum semiglobosum, oligophyllum, laxe imbricatum. Receptaculum planum, paleaceum. Flosculi disci tubulosi, hermaphroditi; radii bilabiati, feminei; labio exteriore maximo, subtrilobo aut integro ; interiore abbreviato, bipartito. Akenia coronata squamulis ciliato-fimbriatis aut plumulis crebris persistentibus.

Herbæ ramis foliisque oppositis, laciniatis; floribus terminalibus, longe pedunculatis; radio aurantiaco. Kunth Synops. 2. p. 491.

G. trilobata, foliis oblongo-lanceolatis dentatis triplinerviis; inferioribus hastato-trilobis. Willden. sp. pl. 3. p. 2228. Hort. Kew. ed. 2. v. 5. p. $122 . \quad$ Bot. mag. 1895.

Galinsoga trilobata. Cavanill.ic. 3. p. 42. t.282. Pers, syn.2. p. 472.

Annual. Stems much branched, ascending, spreading round in every direction, from 1 to 2 feet in height; branches cylindrical, furrowed with numerous channels, and clothed with long spreading hairs. Leaves opposite, attenuated at the base, more or less toothed, triplinerved, slightly hairy; lower ones oblong, hastately 3-lobed, and terminating in a bluntish point; upper ones narrower, lanceolate, sharper toothed, and more pointed. Peduncles terminal, generally in pairs, the branch still lengthening out into other pairs, very hairy, hairs terminated with purple glands. Involucre imbricate, smooth and glossy ; scales obovate, obtuse, 
points curved inwards, membranaceous. Receplacle paleaceous. Chaff lanceolate, keeled, taper-pointed. Rays from 8 to 10, fertile, obcordate, 3-lobed, of a bright yellow, with an orange-coloured mark at the base; lobes blunt and rounded. Florets of the disk tubular, hairy at the base, furnished both with stamens and pistils, opening into 5 blunt reflexed teeth. Stamens 5; filaments distinct, smooth; anthers connected. Style smooth. Stigma bifid. Seeds black, clothed with close pressed white hairs, obconical, or with the largest part uppermost, terminated with a pappus of numerous small serrated chaff.

A very pretty hardy annual, native of South America, and only requires to be sown in the open ground, and to be kept free from weeds; the best time for sowing the seeds, is the latter end of March, or beginning of April ; if sown earlier, they are liable to be injured by the Spring frost. As the plants spread considerably, they should not be allowed to remain too close together; if they are from 9 inches to a foot apart, they will make a better appearance than if they were nearer to each other, flowering from August to October, and ripening abundance of seeds.

Our drawing was taken at the Nursery of Mr. Colvill, in September last.

1. Involucre cut through the middle, to show the chaffy receptacle. 2. Scale of the involucre. 3. Scale of the chaff, showing its keel and attenuated point. 4. Floret spread open, showing its nerves. 5. Stamens, showing the united anthers and distinct filaments. 6. Seed, terminated with its style and bifid stigma. 7. Ripe Seed, terminated with a pappus of small serrated chaff. 


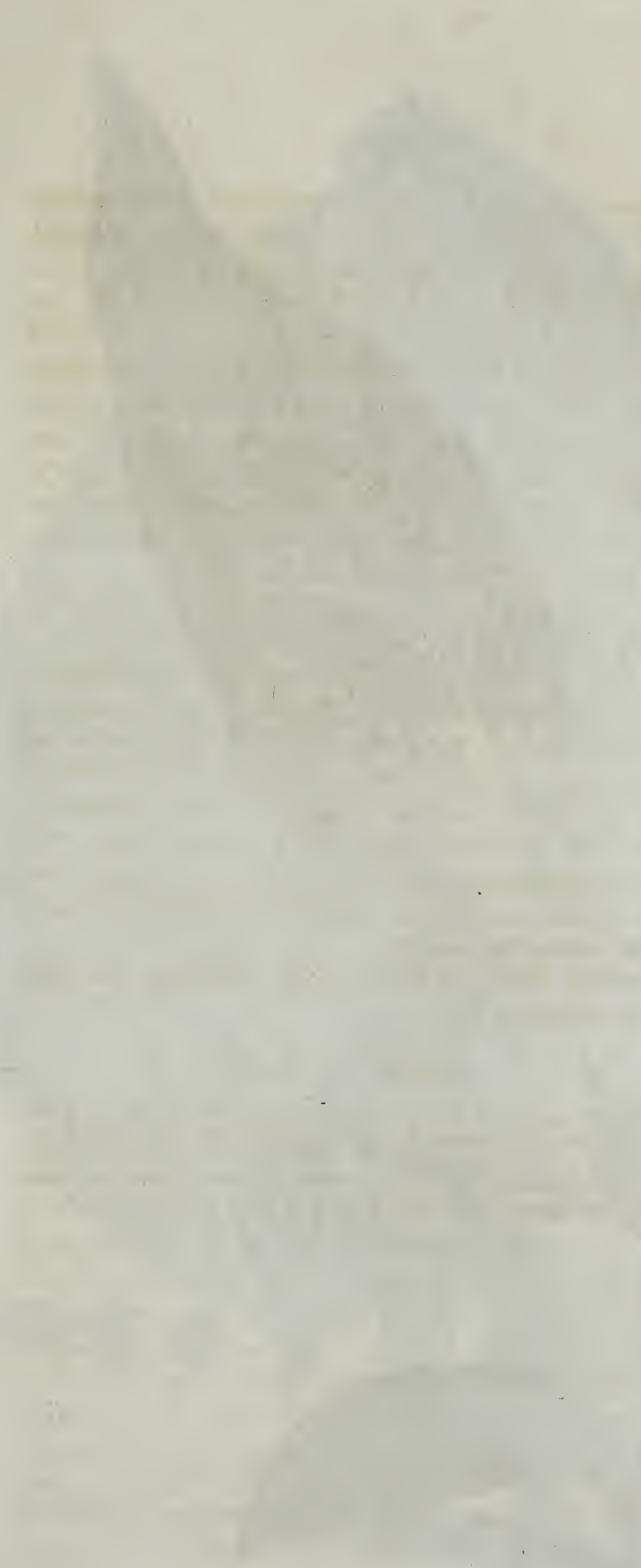




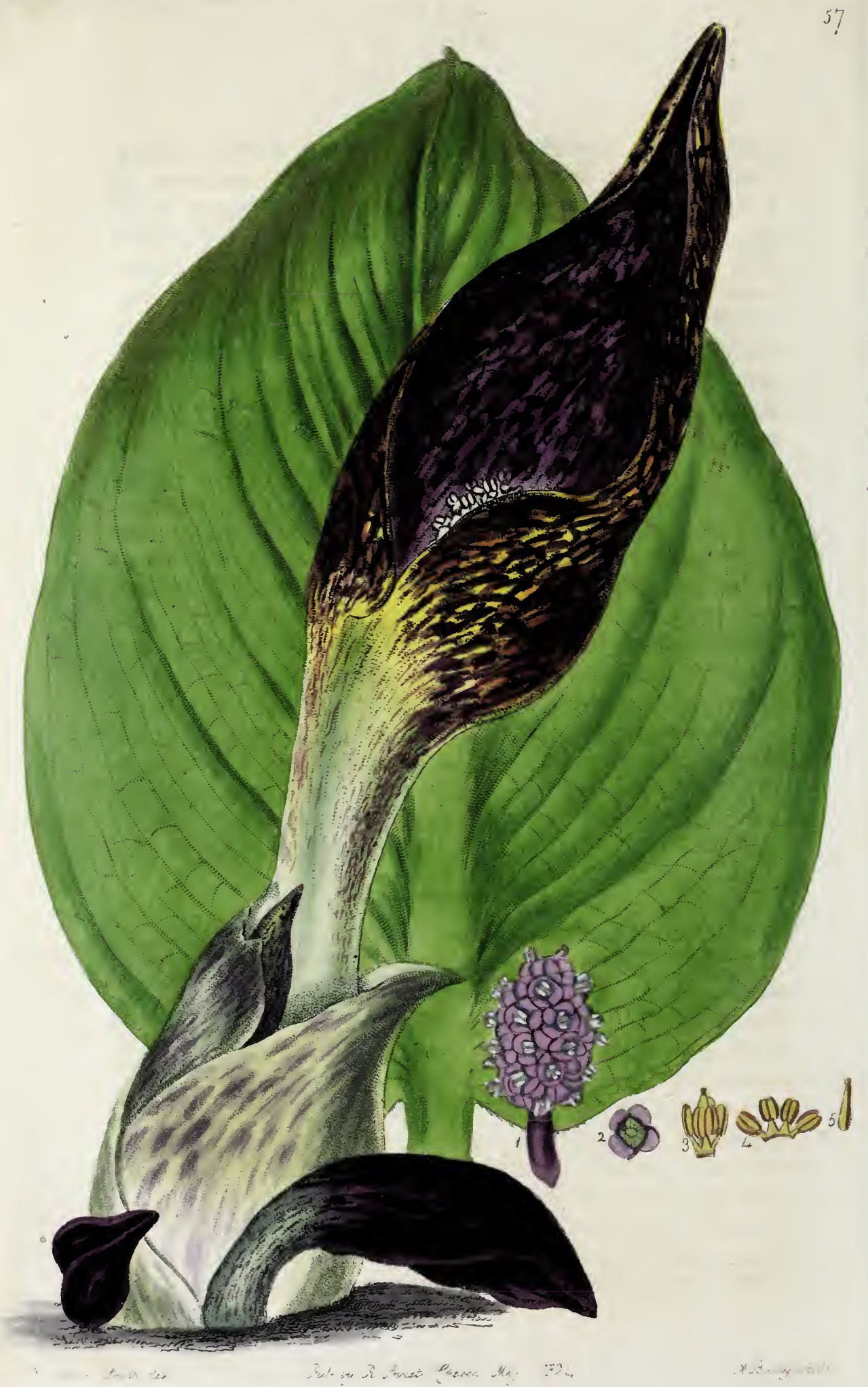




\section{7}

\section{SYMPLOCARPUS fotidus.}

\section{Fetid Symplocarpus, or Scunkweed.}

Natural Order. Aroides. Brown Prodr. 333.

Sect. II. Flores hermaphroditi; Perianthio instructi. ORONTIACEE.

SYMPLOCARPUS. Spatha ventricoso-ovata, cucullata, acuminata, basi convoluta. Spadix subglobosus ; floribus undique tectus. Perianthium 4-partitum. Stamina 4. Bacca coadunatæ, monospermæ. Semina magna, exalbuminosa.

S. foetidus. Salisbury in Hort. trans. Nuttall gen. amer. v. 1. p. 106.

Dracontium foetidum. Willden. sp. pl. 2. p. 288.

Pothos foetida. Botan. magaz. 836. Hort. Kew. ed. 2. v. 1. p. 270.

Root verticillately fibrous, truncate. Leaves large, smooth, pale green, often tinged with purple or brown, ovate-cordate, strongly veined, entire, preceded by conspicuous sheathing stipules, and protected by large glaucous, spathulate-linguiform, veinless bractes. Scapes radical, appearing before the leaves. Spatha discoloured, ovoid, roundish, cucullate, obliquely acuminate, point coarctate, plaited, involutely auriculate at the base, thick and spongy, livid purple, blotched and spotted with pale green, or greenish yellow blotched with purple. Spadix pedunculate, simple, almost sphærical, covered with hermaphrodite flowers. Bractes none. Flowers tessellately imbricate, adnate. Perianthium 4-parted, persistent, divided to the base; segments cucullate, truncate, compressed at the apex, emarginate, at length becoming very thick and spongy. Stamens 4, opposite the divisions of the perianthium; filaments subulate, flat; anthers exserted, short, oblong-oval, 2-celled. Style thick, pyramidal, quadrangular, acuminate; stigma simple, minute, pubescent, shorter than the stamens. Germen immersed in the spongy receptacle, 1-seeded. Seed naked, large, round, inclosed in the common receptacle. Corculum 
small, involute, erect, umbilicately attached to a large solid, carneous perisperm. Chiefly copied from $\mathbf{N u t t a l l . ~}$

"Obs. The seed of the Symplocarpus does not appear to possess any thing like a proper cotyledon, the embryo formed in the exact posture of the growing plant, (with the radical downwards,) differs not from it in any particular, but that of size. In place of a cotyledon there is a sheathing stipule similar to that which is ever after produced; in fact, it is viviparous. The embryon is seated in a small umbilical or hemispherical depression, in the upper end of what may be called a vitellus rather than a perisperm, judging from its functions; this callus, or seminal tubercle, is roundish, and turbinate, nearly as large as a filbert nut, very solid, and carneous, possessing in a high degree the alliaceous fœtor of the grown plant; the mutual point of attachment subsisting betwixt this body and the embryon, is at first a minute and nearly central funiculus, which enlarges and becomes more distinct during the progress of germination; but what appears to be most singular in it, is the length of time which it continues attached to the growing plant, apparently inert at the base of the caudex for 12, or even 18 months." Nutlall loc. cit.

Several plants of this curious species have been lately received from North America, by $\mathrm{Mr}$. Colvill, and the greater part were in full flower when they arrived; from one of those our drawing was taken in March last. The mould in which they grew was a very black soft peat, the kind of soil in which they should be planted in this country, and in a moist situation, as Mr. Nuttall says, they are subaquatics; being so curious a plant, it is well worth cultivation in any collection, as the flowers are very curious, and its fine large light green leaves make a fine appearance after flowering; it is quite hardy, and may be increased by dividing at the root.

1. Spadix in full flower. 2. Perianthium spread open. 3. The Stamens connected at the base, inclosing the Style. 4. The same laid open. 5. Style, terminated by its small bearded Stigma. 



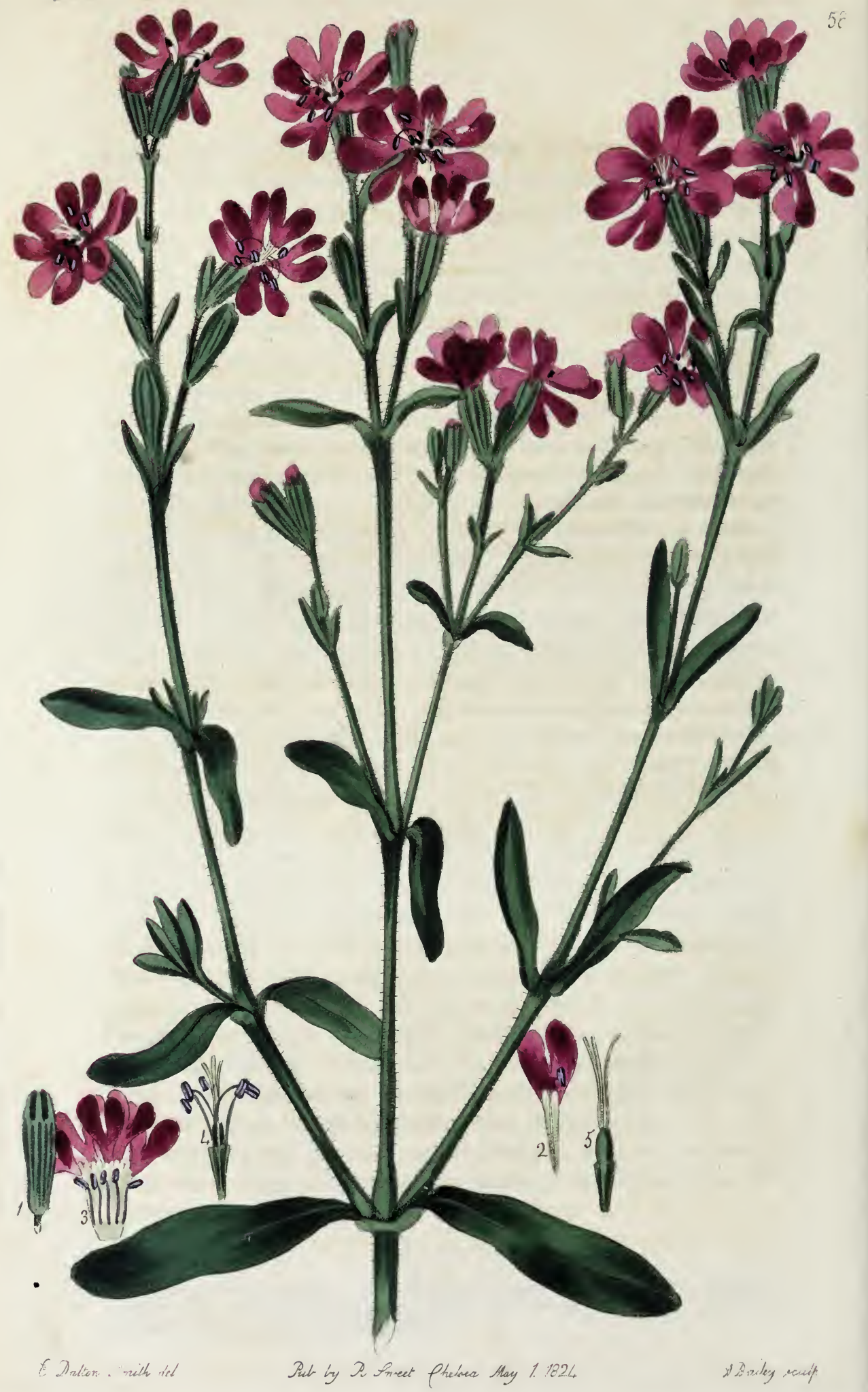




\title{
SILENE vespertina.
}

\author{
Evening Catchfly.
}

Natural Order. Caryophylles. DC. prodr. syst. nat. 1. p. 351.

Tribus I. SILENEE. Sepala coalita in tubum cylindraceum apice 4-5-dentatum.

SILENE. Calyx tubulosus 5-dentatus nudus. Petala 5 unguiculata, fauce sæpissimæ coronata, limbo bifido. Stamina 10. Styli 3. Capsula basi 3-loculares apice in 6 dentes dehiscentes. DC. prodr. 1. p. 367.

Sect. V. StACHYMORPHA. Caulescentes. Flores spicati axillares, non oppositi. Calyx 10 -striatus.

§. 2. Calycibus clavatis.

S. vespertina, pubescens, caulibus ramosis, foliis spathulatis obtusis, spicis geminis secundis, calycibus vesiculato-clavatis, petalis bipartitis, lobis ovatis. DC. loc. cit. 374 .

Silene vespertina. Retz. obs. 3. p. 31. Willden. sp. pl. 2. p. 699 . Botan. magaz. 677.

Silene bipartita. Desf: atl. 1. p. 352. t. 100.

Silene distachya. Brot.fl. lusit. 2. p. 189.

Annual. Stems erect, from a foot to 18 inches in height, much branched from the base, pubescent. Leaves on the lower part of the stem obovate, upper ones spatulate, obtuse; all fringed at the base. Spikes in pairs, terminal, secund, or the flowers leaning to one side; intermediate flower pedunculate. Calyx clavate, vesiculosely pubescent, erect. Petals 2 -parted, coronate, rose-coloured ; lobes ovate; crown connate. Stamens 10, every other one shortest, and joined to the base of the petals; the other 5 longer, and inserted in the receptacle. Styles 3 , spreading. 
This pretty annual is quite hardy, and only requires to be sown in the open flower borders, and to be kept free from weeds. The seeds of our plants were received from Germany, under the name of S. bifida; it is without doubt the S. vespertina of the Botanical Magazine, and also the S. bipartita of Desfontaines, if we may judge from the figures, though, in many Botanical works, they are enumerated as different species. But Decandolle, in his Prodromus, considers them both to belong to the same, and we have thought it safest to follow his opinion. The best time for sowing the seeds is the latter end of March, or beginning of April; and should the plants come up too close together, they should be thinned out, leaving them from 4 to 6 inches apart, they will then grow stronger, and flower in greater perfection. The flowers appear to the greatest advantage of an evening, or early in the morning; for when the sun shines warm on them, the petals curl up, and do not open again till the evening.

Our drawing was taken at the Nursery of Mr. Colvill, last Summer.

1. Calyx. 2. Petal detached, to show the insertion of the Stamen. 3. Corolla spread open, showing the 5 Petals with their crowned Faux, and the insertion of the 5 shortest Stamens. 4. The other 5 longer Stamens inserted in the Receptacle. 5. Germen terminated by the 3 spreading Styles. 



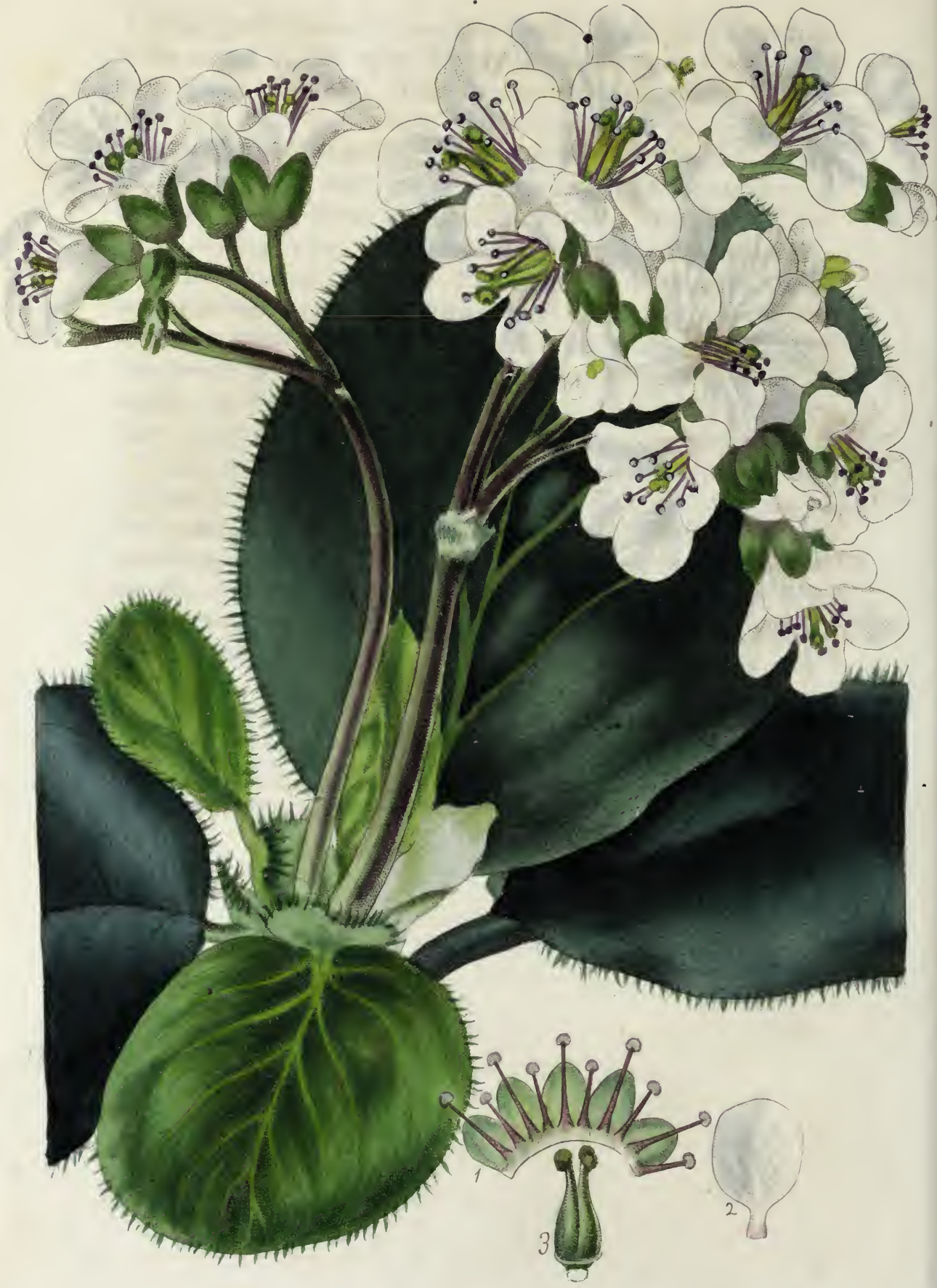




\title{
SAXIFRAGA ligulata.
}

\author{
Fringed-leaved Nepaul Saxifrage.
}

Natural Order. SAXifrages. Juss. gen. 308.

SAXIFRAGA. Calyx 5-fidus. Petala 5, integra. Stamina 10. Styli 2, persistentes. Capsula 2-locularis, 2-valvis è stylis persistentibus birostris ; intra rostra foramine orbiculari aperiens, polysperma. Semina minuta, lævia.

Sect. I. BERGENIA. Calyx campanulatus, 5-fidus, extus rugosus; segmentis conniventibus. Petala unguiculata, calyce inserta. Stamina fauce calycis inserta; filamenta subulata; antherce subrotundæ. Styli intus cavi seminibus pleni! basi coaliti, demùm turgidi et in capsulam profundè bipartitam transientes. Stigmata semiglobosa glabra. Semina cylindracea. Herbæ perennes. Radix crassa, lignosa. Folia ampla carnosa. Petioli stipulis integris membranaceis secus bases utrinque adnatis instructi! Scapi crassi, denudati. Flores thyrsoideopaniculati. D. DoN in Linn. trans. v. 13. p. 343.

S. ligulata, foliis orbiculato-cordatis obovatisve denticulatis ciliatis punctatis glabris, stipulis ciliatis, scapo dichotomo, petalis late orbiculatis.

Saxifraga ligulata. Wallich in Act. Soc. Asiat. XIII. p. 398. cum fig. Don in Linn. trans. 13. p. 348. Hooker Exot. Flor. t. 49.

Megasea? ciliata. Haworth sax. enum p. 7.

Root horizontal, ligneous. Leaves large, leathery, denticulate, ciliate, dotted all over with small punctures, strongly veined underneath, smooth, of a glossy green on the upper side, and of a dull pale green on the lower; lower ones roundly obovate, cordate at the base, from 9 to 10 inches long, and 7 broad; upper ones nearly round, cordate, 4 inches long, and about the same in breadth. Petiole short and thick, nearly 
round, furnished at the base with a large decurrent, membranaceous, fringed Stipule, which clasps the stem. Scapes 2 to 4 , erect, slenderish, smooth, leafless, forked, sometimes divided again; racemes from 4 to 6 -flowered, at first nodding, afterwards becoming upright. Bracte 1, below the fork, membranaceous, dilated at the base, sheathing the scape, acute. Pedicles short, roughish, striate. Calyx campanulate; laciniæ 5, short, roundish, obtuse, dotted. Petals 5 , white, inserted in the calyx, unguiculate; lamina broadly orbiculate. Stamens 10, inserted in the calyx, every other one longest ; filaments smooth, subulate; flesh-coloured; anthers roundish; pollen creamcoloured. Capsule superior, terminating gradually into the Styles. Stigmas 2, large, nearly globular, smonth, and glossy.

This beautiful species of Saxifrage, is a native of Nepaul, and was raised at the Nursery of Mr. Colvill, in the Spring of 1822, from seeds sent him, by Mr. George Potter, from the Botanic Garden, at Calcutta ; 2 of the plants flowered this Spring, from one of which our drawing was taken. It belongs to the same section or subgenus, as the common S. crassifolia, and S. cordifolia, which, with Mr. Don, we agree in considering as distinct species : indeed, we never had any other opinion concerning them.

The present plant will be a valuable addition to our collections, as it flowers so early in Spring; and we expect it will prove as hardy as its near relatives; but, at present, we would advise it to be planted in a warm border, and to be covered with a mat, or a little straw, or fern, in severe weather in Winter. It succeeds well in a rich garden soil, and may be increased, but slowly, from the suckers at the roots.

1. Calyx spread open, showing the insertion of the Stamens. 2. Petal: 3. Germens terminated with 2 capitate Stigmas. 



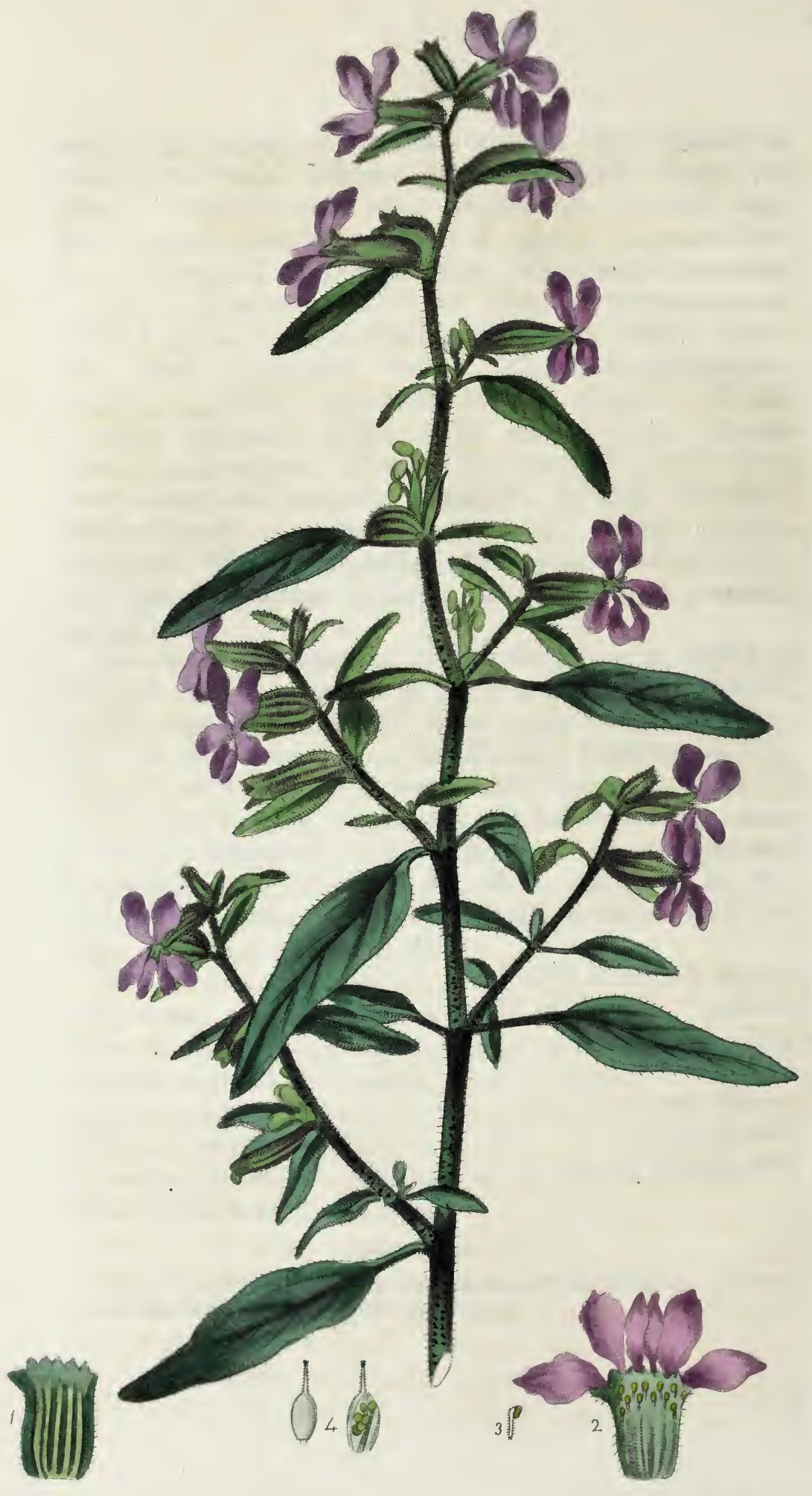
Dation firuth del
Put by R Sreet
Phebea May / 1824
XBarley soulf: 


\section{0}

\section{CUPHEA viscosissima.}

Viscous Cuphea.

Natural Order. SalicaRie. Juss. gen. 330.

CUPHEA. Calyx tubuloso-ventricosus, 6-12-dentatus, inæqualis. Petala 6, (plerumque) inæqualia, calyci inserta. Stamina 10-12-insertione inæqualia, nempè hinc 8 coordinata et conformia, indè 4 minora gemina ordine disposita quorum 2 superiora villosa; anther a subrotundæ. Capsula cum calyce longitudinaliter dehiscens, 1-locularis; conceptaculo triquetro. Semina lentiformia.

C. viscosissima, floribus axillaribus solitariis, foliis ovatolanceolatis supra scabris, caule erecto hispido, stylo piloso. Hort. Kew. ed. 2. vol. 3. p. 150.

Cuphea viscosissima. Willden. sp. pl. 2. p.870. enum. 498. Jacq. hort. vindob. 2. p. 83. t. 177. Pers. syn. 2. p. 8. Barton Flor. north amer. v. 1. $t .18$.

Annual, from a foot to 18 inches in height, erect, branched, of a purplish colour; branches rather flexuose, thickly clothed with short stiff purplish hairs, covered with a viscous substance, as are the petioles, peduncles, and calyx. Leaves ovate, or ovately lanceolate, oblique at the base, entire, bluntish, hairy on both sides. Petioles slender, shorter than the leaves, flattened on the upper side, and rounded on the lower. Flowers small, axillary, solitary. Peduncles very short, scarcely any. Calyx tubular, ventricose, 12-angled, and terminated with 6 very short blunt teeth; angles of a darker colour, hispid, the channels between them smooth and naked. Petals 6, unequal, the 2 upper ones largest, unguiculate, inserted in the calyx, of a light purple, or lilac. Stamens 12, unequally 
inserted in the tube of the calyx; filaments hairy, the 2 upper ones villous; anthers incumbent. Style 1, hairy, slender towards the point, and terminated with a small capitate stigma. Capsule bursting longitudinally soon after the flower drops, and showing its naked seeds, which continue to encrease in size, and remain firmly attached till ripe. Seeds several, lentiform, facing the side that the capsule is burst, in a kind of secund spike.

Our drawing was taken at the Nursery of Mr. Colvill, from plants raised from seeds last Spring; they began flowering when they were scarcely 4 inches high, and continued to bloom the whole of the Summer, and ripened abundance of seeds; the first flowers were very small, agreeing exactly in size with those in the figure of Barton's Flora, of North America; but as the plants increased in strength, the flowers became larger, at length, making a handsome appearance. The bursting of the capsules is a very curious circumstance, and if the plants are not well watched, the seeds will drop out and be lost.

The present plant has been generally considered as a greenhouse biennial, but ours were certainly hardy annuals, flowering very soon after being out of the ground, and dying as soon as the seeds were ripened. The best time for sowing the seeds, is the beginning of April, if the weather prove mild; they should be sown in a rich soil, in a warm border.

1. Calyx. 2. Calyx spread open, to show the insertion of the Petals and Stamens. 3. One of the upper Stamens detached, to show the villous filament. 4. Capsules, showing the hairy Style and capitate Stigma: one of them burst, showing the situation of the seeds. 


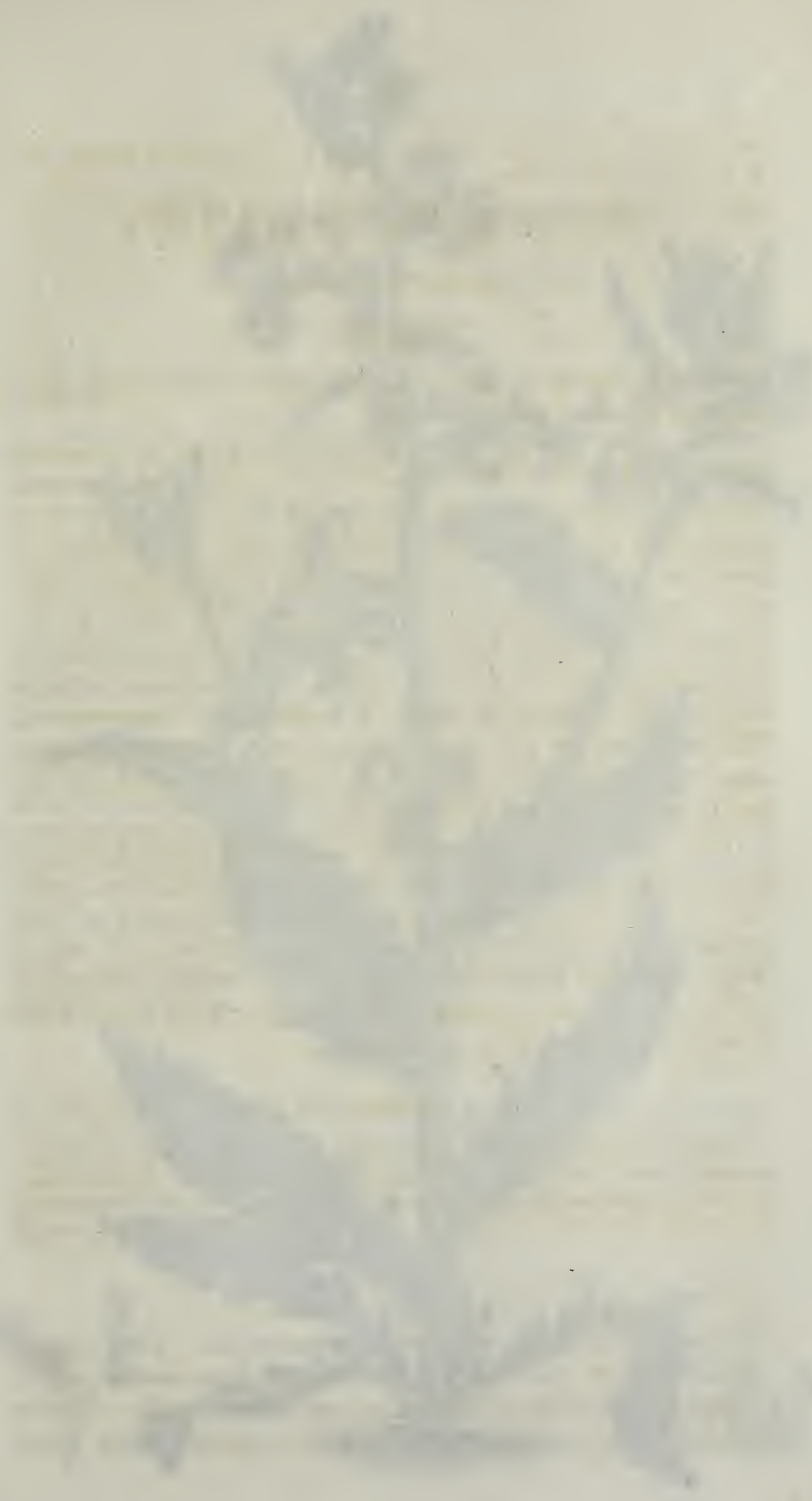




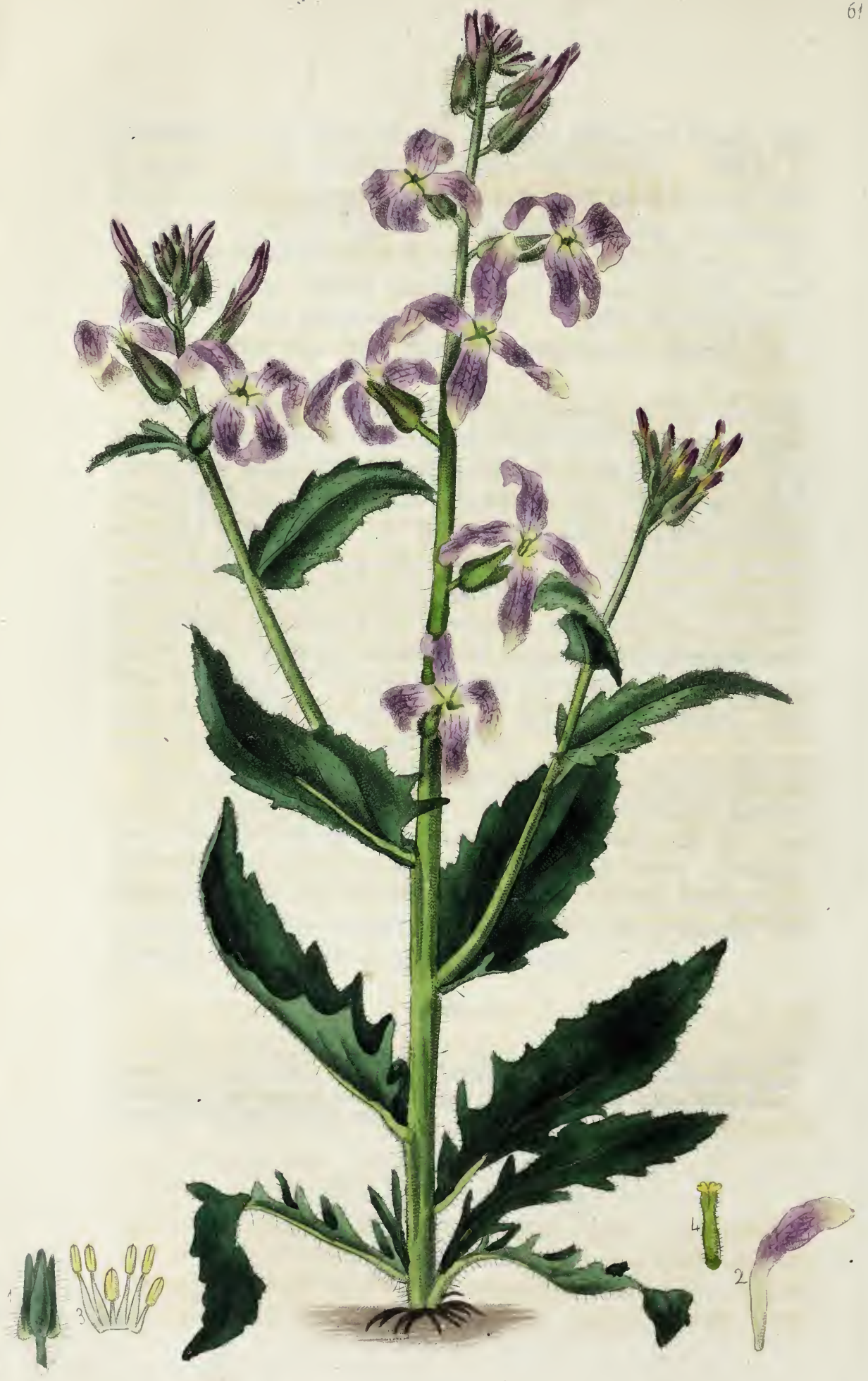

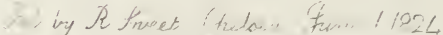




\section{HESPERIS fragrans.}

\section{Evening-Scented Rocket.}

Natural Order. CRUCIFEre. DC. reg. veg. syst. nat. v. 2. p. 139.

Subordo II. Notorhizes. Cotyledones plance, incumbentes. Radicula dorsalis. Semina ovata, immarginata. DC. $p .150$.

Tribus VII. SISYMBREE SEU NOTORHIZEE SILIQUOSE.

HESPERIS. Calyx clausus, bisaccatus. Petala unguiculata, limbo patente obtuso aut emarginato. Stamina libera, tetradynama. Glandula virides, subannulatæ, ad basin staminum lateralium. Siliqua stricta subtetragona aut compressa, stigmatibus 2 erectis sessilibus conniventibus terminata. Semina oblonga, subtriquetra, pendula, 1 serialia. Cotyledones planæ incumbentes. Herbæ annua, biennes perennesve; radice fibrosa; caule tereti erecto aut diffuso. Folia ovato-lanceolata aut oblonga, dentata aut lyrato-runcinata. Plantæ plerague pilis aliis lymphaticis simplicibus ramosisve, aliis prasertim ad apicem pilis glandulosis instructa et inde quasi bituminosa. Racemi terminales, ebracteati, erecti. Pedicelli filiformes, post anthesin non incrassati. Flores albi aut purpurascentes, sape versicolores, interdum odorati. $\quad$ DC. v. 2. p. 446.

Sect. I. HEsperIs. Petalorum limbi lineares, sordide ex albido flavo-purpurascentes, vespere odorati. Siliqua valvis carinatis subanceps, septo fungoso.

H. fragrans, pedicellis villosis calyce villosissimo duplo brevioribus, petalorum laminis oblongis undulatis, foliis inferioribus petiolatis runcinato-lanceolatis obtusiusculis : superioribus subsessilibus ovatis acuminatis basi grosse dentatis.

Hesperis fragrans. Fischer Mss.

Biennial. Stem erect, not much branched, thickly clothed with soft villous down, and longer hairs intermixed. Leaves runcinate, villosely hispid, roughish ; lower ones petiolate, lanceolate, bluntish, segments or 
teeth pointed, the lowermost longest; upper ones nearly sessile, or on very short footstalks, ovate, taper-pointed, sharply toothed at the base, and entire from about the middle. Racemes elongated, many-flowered, thickly clothed with long villous hairs, and smaller ones intermixed. Bractes none. Pedicles short, scarcely half the length of the calyx, villous. Calyx of 4 sepals, closed, 2-gibbous at the base, bearded at the point; sepals linearly lanceolate, slightly keeled, green, tinged with purple, villous. Petals 4, unguis about the length of the sepals ; lamina oblong, undulate, terminating in a very short bluntish mucro, a little longer than the unguis, of a dull purple, reticulately veined. Stamens 6,4 long and 2 short, enclosed in the calyx; filaments obliquely flattened at the base, and narrowing upwards; anthers sagittate. Siliqua villosely hispid, terminated by 2 connivent 2 -lobed Stigmas.

Our drawing was taken from a plant communicated to us by our friend, Mr. W. Anderson, Curator of the Apothecaries' Garden, at Chelsea, where it was raised from seed sent him by Dr. Fischer, of the Royal Botanic Garden, St. Petersburgh, under the name that we have adopted; we do not find it recorded in either of the late publications of M. Decandolle, and believe it has not been before published; it is a hardy biennial, flowering the second season after being sown. It may either be sown in the open ground, or in pots ; and is particularly suited for the latter, as it can then be moved into or near a room, as its agreeable fragrance is delightful of an evening, though it is quite destitute of scent during the day. It thrives well in a rich garden soil, and is only to be propagated by seeds ; the young plants should be transplanted as soon as possible, or they will be likely to damp off.

1. Calyx. 2. Petal. 3. The 6 Stamens, 4 long, and 2 short. 4. The young Siliqua terminated by its 2 bilobed Stigmas. 



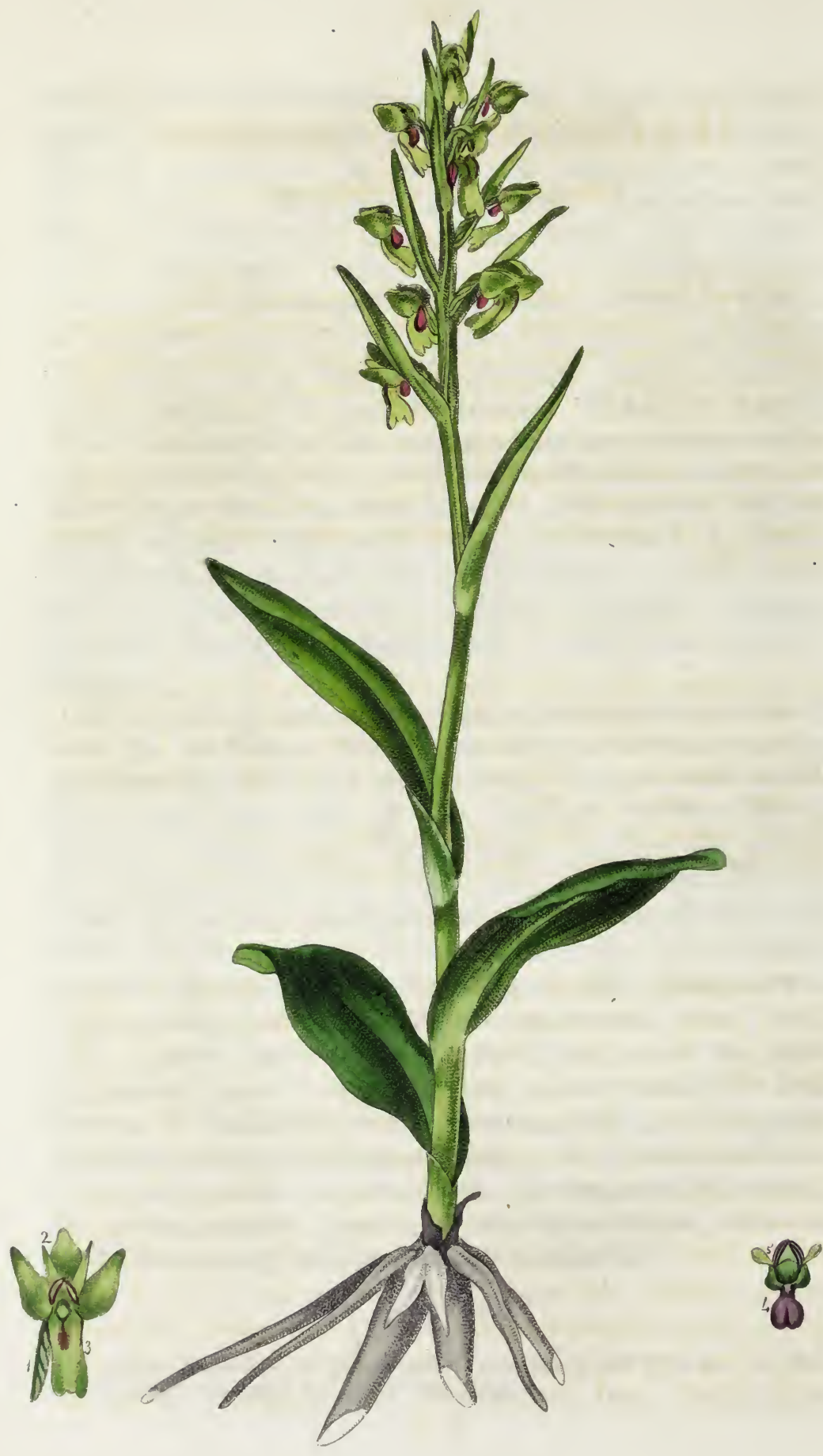




\title{
62
}

\section{HABENARIA bracteata.}

\author{
Long-bracted Habenaria.
}

Naturul Order. ORCHIDEe. Brown prodr. 309.

Sect. I. Monandre. Anthera adnata subterminalis persistens. Pollinis massa e lobulis angulatis elastice cohærentibus; basi affixæ. Brown in Hort. Kew. ed. 2. v. 5. p. 188.

HABENARIA. Perianthium ringens, foliolis 3. v. 5 in galea conniventibus. Labellum basi subtus calcaratum vo subsaccatum. Anthera terminalis, loculis adnatis, basibus quandoque solutis elongatis. Massa Pollinis pedicellatæ, pedicellis singulis basi glandulæ respondenti nudæ insertis. Brown prodr. 312.

H. bracteata, cornu abbreviato didymo, labello lineari retusotridentato: lateralibus obtusis ; medio obsoleto, bracteis flore duplo longioribus. Brown in Hort. Kew. ed. 2. v. 5. p. 192. Orchis bracteata. Willden. sp. pl. 4. p. 34. Pursh Flor. Amer. Sept. 2. p. 587.

Orchis bractealis. Salisb. pardis. 110.

Satyrium bracteatum. Pers. syn. 2. p. 507.

Perennial. Root palmate. Stem about a span high, leafy, furrowed, angular. Leaves channelled, clasping the stem, keeled and nerved underneath, bluntish ; lower ones oblong; upper ones lanceolate, more pointed. Spikes short, in our specimen 9-flowered. Bractes linearly lanceolate, channelled, bluntish, about double the length of the flowers. Flowers green, scentless, erect, or scarcely nodding. Germen channelled, twisted. Perianthium ringent; three outer leaflets ovate, obtuse, the middle one rather the shortest and narrowest; two inner ones narrowly lanceolate, bluntish. Labellum broadly linear, point slightly 3-toothed, the teeth blunt, and the middle one shortest. Spur or R 2 
pouch at the base of the Labellum, short and inflated, 2-lobed, of a transparent flesh-colour. Anther joined to the point of the stigma; lobes diverging, and opening in front for the exclusion of the Pollen masses, which are pedicled and attached at the base.

This curious plant was imported from North America last Winter, and was procured for Mr. Colvill, with several other Orchideous plants from the same country, by Mr. George Charlwood. It thrives well with us at present in a pot of red sandy loam, and we are in hopes that it will ripen its seeds. The seeds of the different species of Orchideæ have been generally supposed to be very difficult to make grow, but we have succeeded well in raising some of them, and have no doubt but the whole might be raised in the same way; we have now a pot of seedlings of Cymbidium ensifolium thriving very well, and we managed them in the following manner : in October last; we filled a pot with peat earth, within half an inch of the brim, we then planted it all over with small turfs of very short moss, on the moss we scattered our seeds, and washed them in between the blades with watering them; we then placed them in the hothouse, and managed them in the same manner as any other common seeds, watering them occasionally when dry; the moss continued to grow, and the latter end of April the young plants began to make their appearance, and others still continue to show themselves. If sown in any other way, we think them not so likely to succeed, the seed being so very small, that they will soon lose their vegetating quality.

1. Germen. 2. The 5 leaflets of the Perianthium. 3. Labellum, showing its 3 short blunt teeth. 4. Spur or Pouch. 5. Anther, showing its diverging lobes, each burst, showing the pedicled Pollen masses attached to the base, and freed from the Anther, all magnified. 



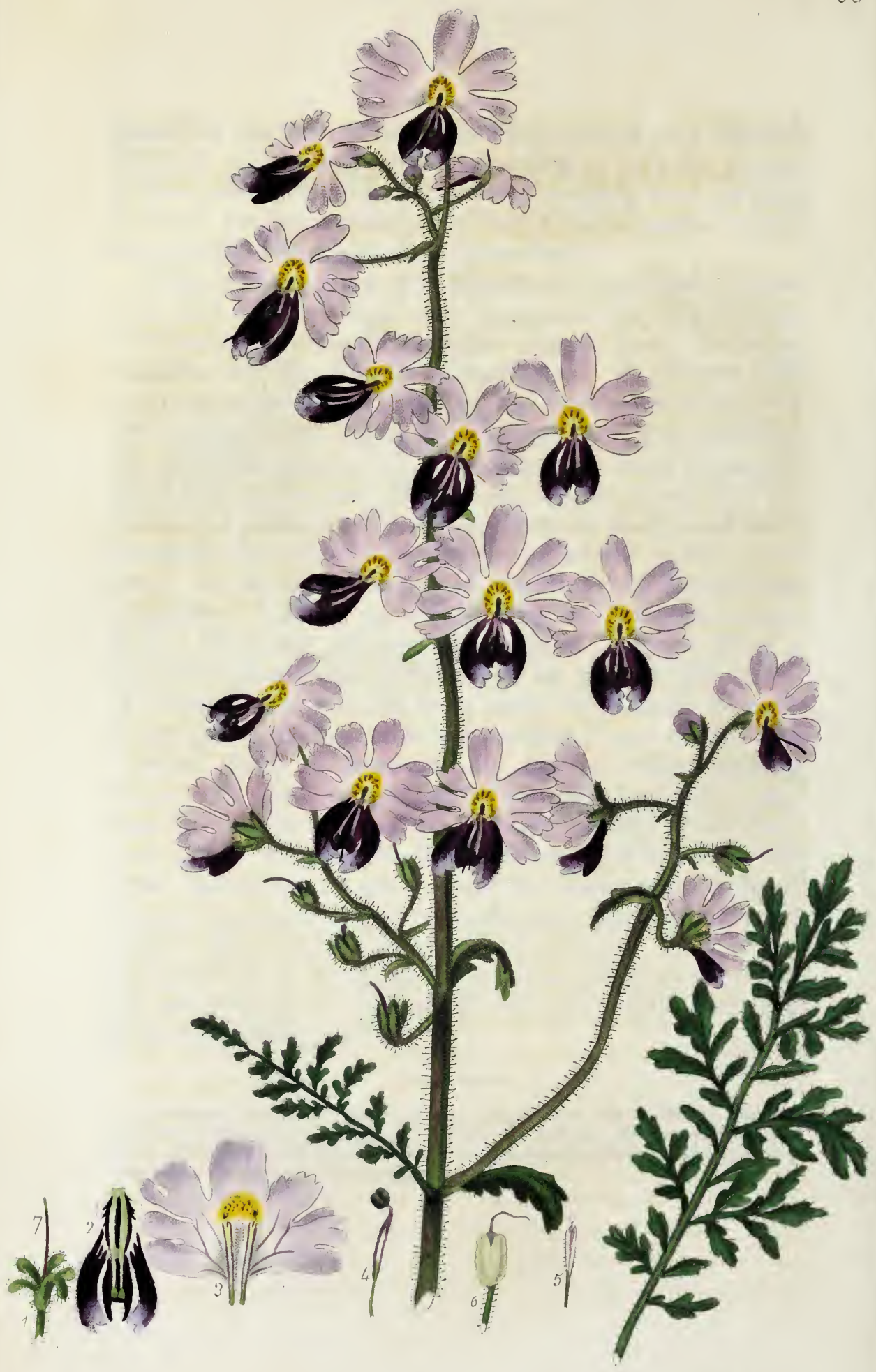




\title{
SCHIZANTHUS pinnatus.
}

\author{
Winged-leaved Schizanthus.
}

Natural Order. Scrophularina. Brown prodr. 433. Sect. I. Stamina duo antherifera. Capsula bilocularis. SCHIZANTHUS. Corolla irregularis: labio superiore quinquefido; inferiore tripartito. Stamina 2 antherifera: 2 sterilia ; filamentis villosis. Capsula bilocularis.

S. pinnatus, foliis interrupte pinnatis : inferioribus bipinnatis, floribus paniculatis : racemis secundis.

Schizanthus pinnatus. Flor. peruv. 1. p. 13 t. 17. Pers. syn. 2. p. 161. Botan. regist. 725. Botan. magaz. 2404. Hooker exot. flor. 73.

Annual. Stem from 2 to 3 feet high, erect, much branched; branches slender, thickly clothed with soft villous glandular hairs, and terminated with a panicle of flowers. Leaves interruptedly pinnate, more or less hairy; lower ones bipinnate with smaller leaflets intermixed; leaflets oblong, very blunt, more or less toothed with blunt rounded teeth ; upper leaves pinnatifid, those near the flowers entire, oblong, obtuse, more sharply toothed, very hairy. Flowers in panicles, or compound secund racemes, terminating the stem, varying in colour on different plants. Bractes 2, at the base of the pedicle, one double the size of the other, oblong, obtuse, very hairy. Pedicles slender, nodding. Calyx 5-parted, segments unequal, oblong, obtuse, fringed. Corolla irregular; upper lip 5-cleft, side laciniæ forked, those again notched, the upper one entire, or slightly emarginate; lower lip 3-parted, outer laciniæ falcate, bending towards each other, their points truncate, middle one concave, connivent, enclosing the stamens, which are elastic, and spring 
towards the stigma as soon as touched. Stamens 4, inserted in the mouth, 2 barren, and 2 bearing anthers; sterile filaments short, very villous; fertile ones longer, slightly hairy, and elastic, springing upwards as soon as touched; anthers attached to the filament, a little above their base, 2-celled, discharging their pollen by the spring of the filament. Pollen ash-coloured. Germen smooth. Style smooth, purple. Stigma a simple point.

This very beautiful annual plant is a great acquisition to our gardens, where it has been lately introduced. Seeds of it were first brought to this country by Lady Cochrane, and they have now found their way into many collections; the plant from which our drawing was made, was presented to Mr. Colvill, by the late J. Walker, Esq. of Arno's Grove, Southgate, who raised it from seed; we find it succeeds well in the open air, where it makes a grand appearance, and continues in full bloom for a considerable time; our plants grew to the height of 3 feet, branching out in an elegant manner, and ripened their seeds. Cuttings of them were taken off in September, and planted under hand-glasses in the open ground, where they soon rooted; we then planted them in small pots, and preserved them in the greenhouse through the Winter; in March they began to flower, and are now covered with flowers and seeds.

Seeds sown in pots early in Spring, and placed in a greenhouse, or frame, will flower much earlier than those sown in the open ground; a rich light soil suits them best, and a sheltered situation, as their tender shoots are apt to be broken by rough winds if they are too much exposed.

1. Calyx. 2. The lower lip of the Corolla divided from the upper, to show the insertion of the 2 fertile Stamens. 3. The upper lip, showing the 2 barren Stamens. 4. Fertile stamen detached. 5. Barren ditto. 6. Capsule nearly ripe. 7. Style and Stigma. 



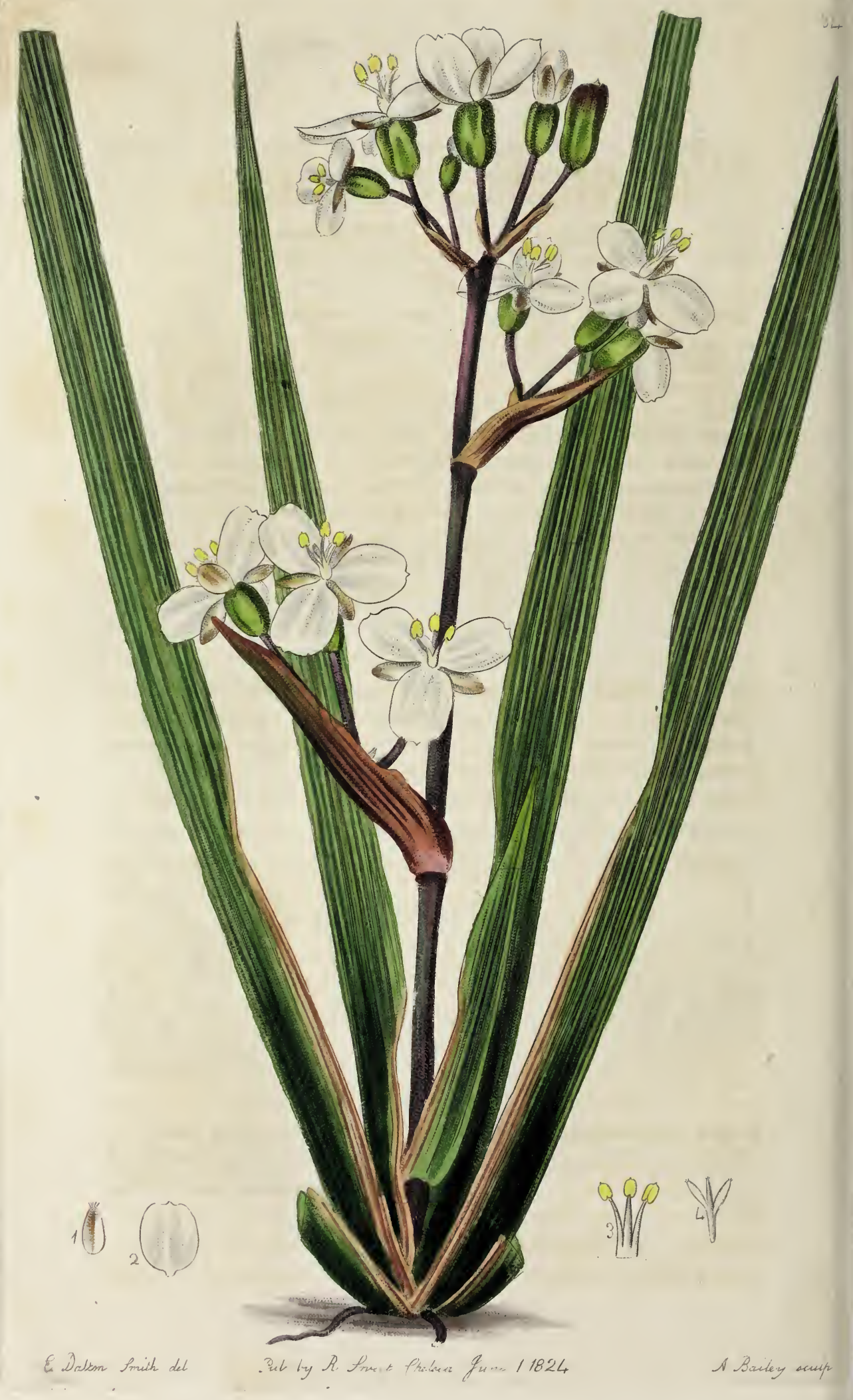




\title{
64
}

\section{RENEALMIA grandiflora.}

\author{
Largest-flowered Renealmia.
}

Natural Order. Iridee. Brown prodr. 302.

RENEALMIA. Perianthium 6-partitum, regulare ; foliolis interioribus majoribus, basi angustatis. Filamenta infrà connata v. distincta, suprà patentia. Stigmata 3, involuta-filiformia, acuta. Capsula obovato-clavata. Semina angulata. Inflorescentia subpaniculata, fasciculorum spathis abbreviatis.

Herbæ sylvicola, glabra. Radix fibrosa, nunc e rhizomate. Folia graminea, laxa, nervosa. Caulis teretiusculus quandoque divisus. Fasciculi alterni, umbellati, spathis persistentibus. Perianthium album, patulum, citò deciduum; foliolis exterioribus extùs sapiùs virescentibus; interioribus sapè unguiculatis. Capsula membranacea. Semina biseriata, atra. Brown prodr. Addenda. p. 591.

R. grandiflora, caule paniculato, foliis (10-18-unc.) nervosis margine scabriusculis, perianthii foliolis exterioribus ovalioblongis : interioribus 3-plo majoribus obovato-oblongis subunguiculatis, filamentis basi connatis.

Renealmia grandiflora. Brown prodr. ADDENDA in OBS.

Perennial. Stem short, much branched at the base. Leaves fan-like or distichous, sheathing at the base, narrowly sword-shaped, taper-pointed, roughish on the edges, many-nerved, of a lively green edged with a yellowish-brown, from 10 to 18 inches in length; sheaths membranaceous, of a brownish orange colour. Scape erect, scarcely as long as the leaves, nearly cylindrical or slightly flattened, smooth, of a purplish colour. Flowers white, panicled. Sheaths leaf-like, lower one longer than the pedicles, upper ones shorter. Pedicles cylindrical, gradually thickening upwards, of a purplish colour, with a small membranaceous bracte attached near the base. Germen bluntly trigonal, uneven. Perianthium 6-parted, seated on the germen; outer leaflets oval or oblong, bearded at the 
point, white with a purple keel down the back; inner leaflets obovately-oblong, slightly emarginate, narrowed at the base, 3 or 4 times larger than the outer ones. Stamens 3 ; filaments slightly connected at the base, flat, tapering upwards; anthers sagittate, 2-celled. Style short, smooth. Stigmas 3, flat, tapering to a point.

The present subject is a native of New Zealand, where seeds of it were collected by Mr. John Richardson, who disposed of them and numerous other seeds of new and very rare plants from that country and New Holland, to Mr. Colvill, and plants raised from them are now in Mr. C.'s collection ; many of which have flowered. There are now in flower Boronia serrulata, a new species of Podolobium, and a beautiful new plant from King George's Sound, we believe a new species of Callistachys. Many other interesting plants from the same collection we expect to see flower this season, which, we presume, will still vex Billy Aiton, and his staunch radical friend old Cobbett!!

Several plants of the present species were planted out in the open ground last Spring, where they have remained to the present time, and have received no injury from the Winter, but are growing as freely as those that have been protected in a greenhouse; the one from which our drawing was taken, flowered in April, but from the appearance of the plant we suspect it will bloom at various seasons. It grows freely in a rich light soil, and may be increased by dividing at the root, or by seeds.

Mr. Brown was so obliging as to favour us with a sight of a drawing from a native specimen; in this the plant was much stronger, the flowers larger, and the panicle 4 times the size of ours, so that it will become a handsome plant when of larger growth.

1. Onter leaflet of the Perianthium, showing its fringed point. 2. Inner ditto, showing its narrow base. 3. The 3 Stamens spread open, showing their slight connection at the base. 4. Style terminated by 3 flat spreading Stigmas. 


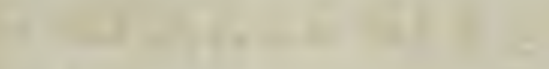
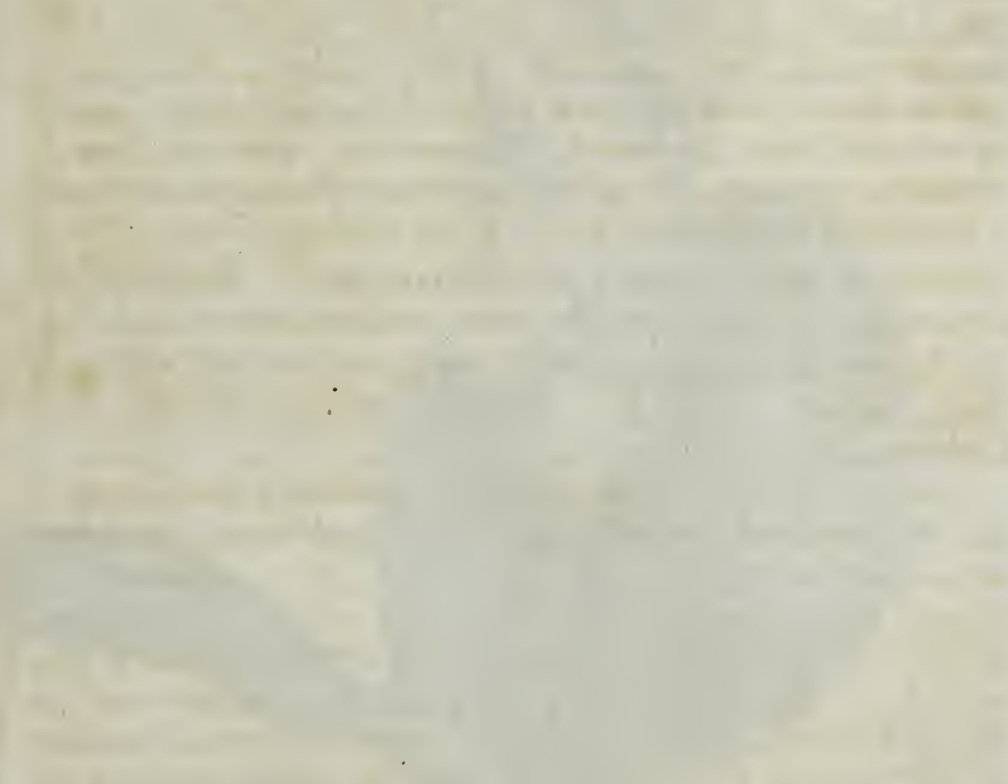

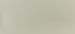

$+$
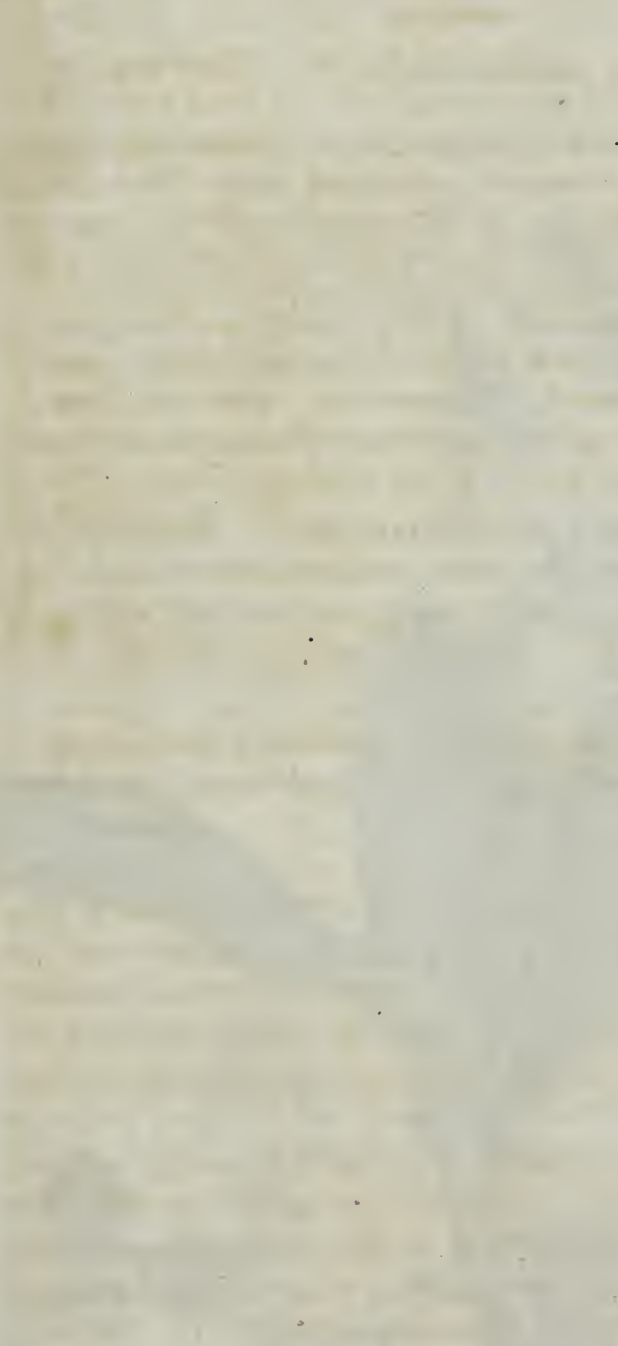

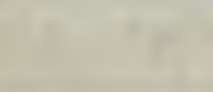




\title{
ORCHIS spectabilis.
}

\author{
Showy American Orchis.
}

Natural Order. ORCHIDEe. Brown prodr. 309.

Sect. I. Monandre. Anthera adnata subterminalis persistens. Pollinis massa e lobulis angulatis elastice cohærentibus : basi affixæ. Brown in Hort. Kew. ed. 2. v. 5. p. 188.

ORCHIS. Perianthium ringens. Labellum basi subtus calcaratum. Glandula (1-2) pedicellorum pollinis inclusæ cucullo unico. Brown.

O. spectabilis, labello obovato indiviso crenulato retuso, foliolis perianthii conniventibus rectis : lateralibus longioribus, cornu clavato longitudine germinis, bracteis flore longioribus, scapo acute 5-angulo subaphyllo.

Orchis spectabilis. Willden. sp. pl.4. p. 36. Pers. syn.2. p. 506. Pursh. fl. amer. sept. 2. p. 587. Nuttall gen. amer. 2. p. 189. Lodd. bot. cab. 78.

Orchis humilis. Mich. flor. amer. 2. p. 155. Pers. syn. 2. p. 506.

Root, in our plant, fasciculate, (palmate, according to Nuttall.) Leaves 2, large, roundly oval, reticulately veined underneath, smooth and shining above. Scape acutely 5 -sided, leafless, (sometimes producing a leaf, Nuttall.) few-flowered. Bractes large, leaf-like, lanceolate, obtuse, overtopping the flowers. Flowers large, violet-scented, all facing one side. Germen angular, slightly twisted, bent towards the flower. Leaflets of the Perianthium connivent and adhering, of a light purple on the outside, and darker within; side ones rather the longest. Labellum white, or slightly tinged with blush, broadly ovate, crenulate, 
slightly retuse. Spur compressed, blunt, or clubshaped at the point, about the length of the germen. Stamen attached to the point of the stigma, the 2 lobes diverging. Pollen masses pedicled, and covered with a hood.

Our drawing of this rare and handsome plant, was made at the Nursery of Mr. Colvill; it had been lately imported from North America, and was procured for Mr.C. by Mr. George Charlwood. The plants were potted in a very sandy red loam, where they flowered strong, and are appearing to thrive very well, and we have little doubt but the whole of the Orchideous plants might be managed as well as any others, by proper attention; many of them, we think, would succeed well in a frame, or pit, and to be covered occasionally with glass, particularly when the weather was very wet, as moisture is much more injurious to them than cold; the soil should be prepared for them according to the different species; the greater number succeeds best in light sandy loam, a few species prefer peat, and many are fond of a chalky soil, which could be imitated by pounding or grinding chalk, and mixing it with the other mould; the bed should be made a little sloping, that the wet may pass more readily off. Some of the sorts that prefer chalky hills, might be planted on a little mount made of chalk, and covered with sandy loam mixed with powdered chalk; in such a situation, we believe many of them would thrive well.

1. Part of the Flower-stem, to show the 5 angles. 2. Germen. 3. The 3 onter leaflets of the Perianthium. 4. The 2 inner leaflets. 5. Labellum. 6. Spur. 7. Anther, slowing its diverging lobes covered with a hood. 8. The same divested of the hood, showing its pedicled pollen masses attached to 2 little glands at the base. 


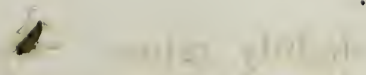

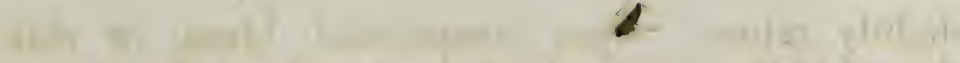

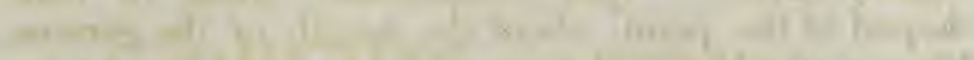

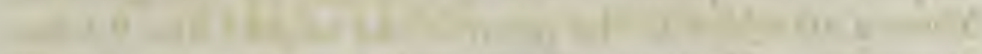

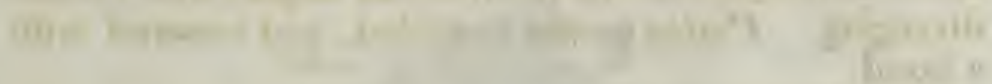

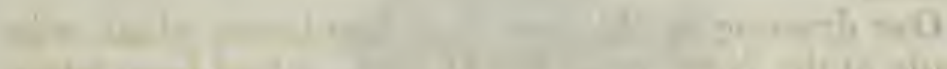

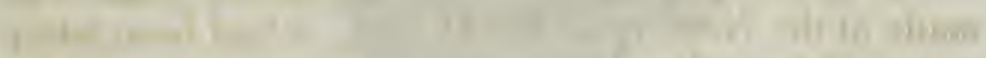

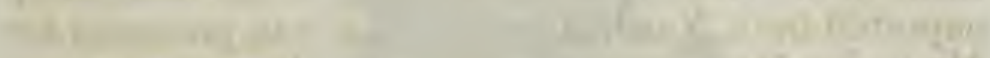

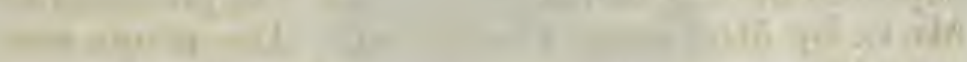

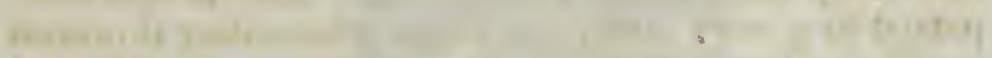

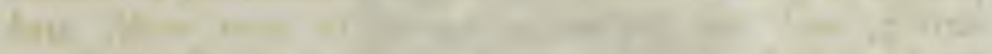

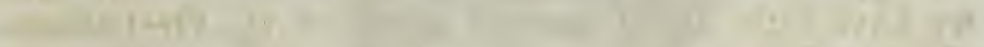

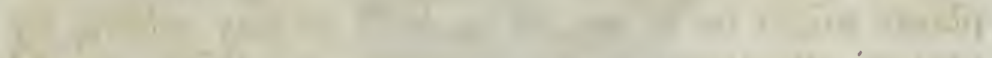
Linn and

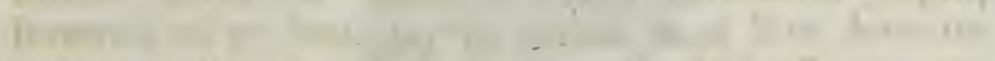

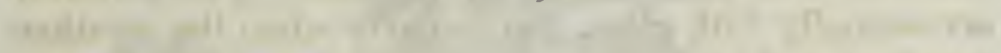

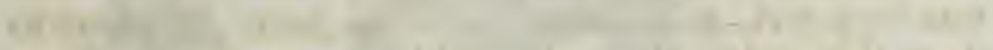

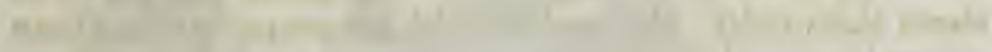

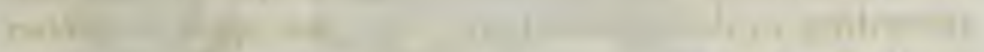

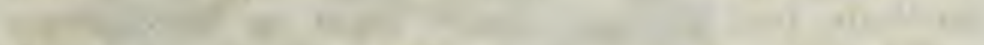

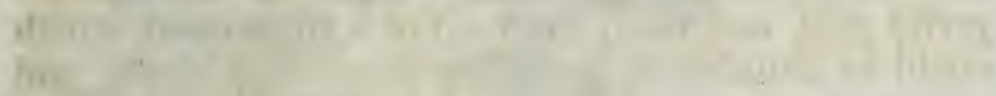

$+1$

IIn:

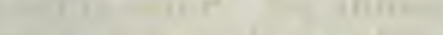

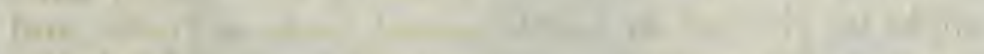
any

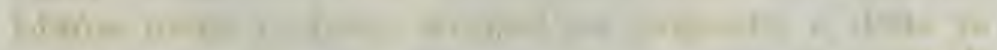
inil

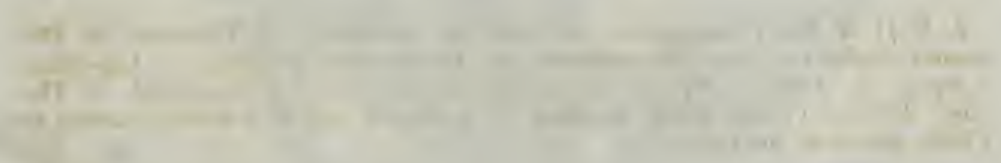




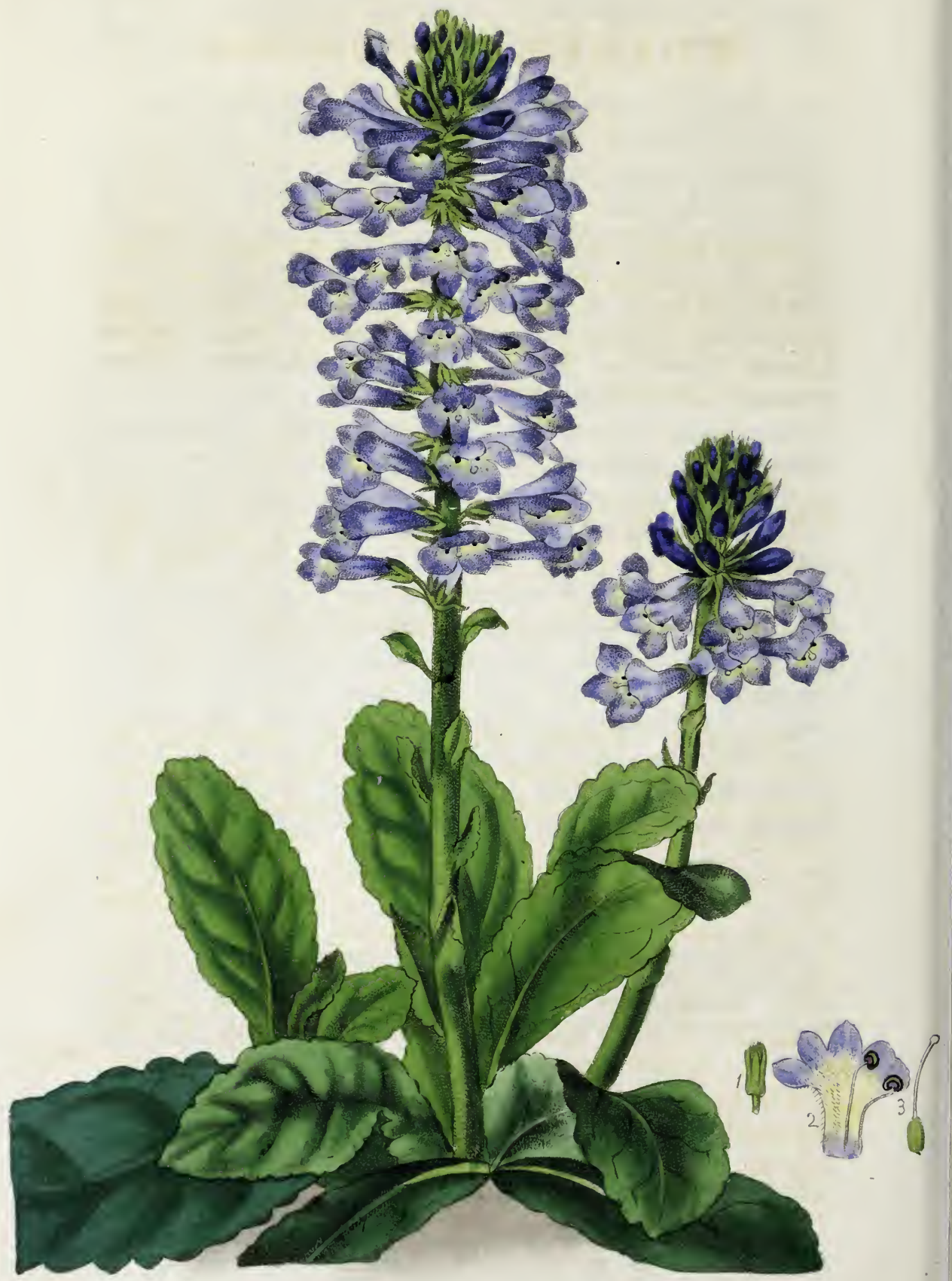

D. Dien truch sel 


\title{
WULFENIA carinthiaca.
}

\author{
Carinthian Wulfenia.
}

Natural Order. Scrophularina. Brown prodr. 433. Sect. I. Stamina duo antherifera. Capsula bilocularis.

WULFENIA. Calyx 5-partitus. Corolla ringens : labio superiore brevi integro; inferiore 3-partito, fauce barbata. Capsula 2-locularis. Folia radicalia obovata obtusa. Flores pedunculati, secundi, carulei.

Wulfenia carinthiaca. Jacq. miscell. 2. p. 62. t.8. $f$.1. Icon. rar. 1. t. 2. Pers. syn. 1. p. 14. Willd. enum. 1. p. 24. Roem. et Schult. 1. 17\%. Link enum. 1. p. 27. Hort. sub. lond. Addenda.

Pæderota Wulfenia. Lamarck encycl.t. 13. f. 2.

Perennial. Leaves radical, tufted, spreading flat on the ground, younger ones erect, obovate, obtuse, slender at the base, notched with rounded blunt crenatures, which are again slightly notched. Scape erect, smooth, leafy ; the leaves small, sessile, clasping the stem, acute, margins bent backwards. Spike at first nodding, afterwards becoming erect, and growing to a considerable length. Flowers of a bright blue, leaning to one side. Pedicles short. Calyx 5-parted; laciniæ unequal, lanceolate, acute. Corolla ringent; upper lip short, entire, slightly crenulate; lower lip 3-parted, densely bearded in the mouth, segments rounded, with a small point, side ones largest. Stamens 2, inserted in the tube, and included within the mouth : filaments smooth; anthers incum- 
bent; pollen ash-coloured. Style smooth, exserted. Stigma capitate.

For the opportunity of giving a figure of this rare plant, we are obliged to A. B. Lambert, Esq. who sent us a fine plant of it in full bloom, that had been grown at his seat at Boyton. Large plants of it make a handsome appearance, when covered with numerous spikes of beautiful blue flowers, which last a considerable time. Our drawing was taken about the middle of April, and other spikes continued to flower till near the end of May. It succeeds well in a rich loamy soil in a sheltered situation, and may be increased by dividing at the root, or by seeds.

1. Calyx. 2. Corolla spread open, to show its bearded month, and the insertion of the stamens. 3. Germen, Style, and Stigma. 



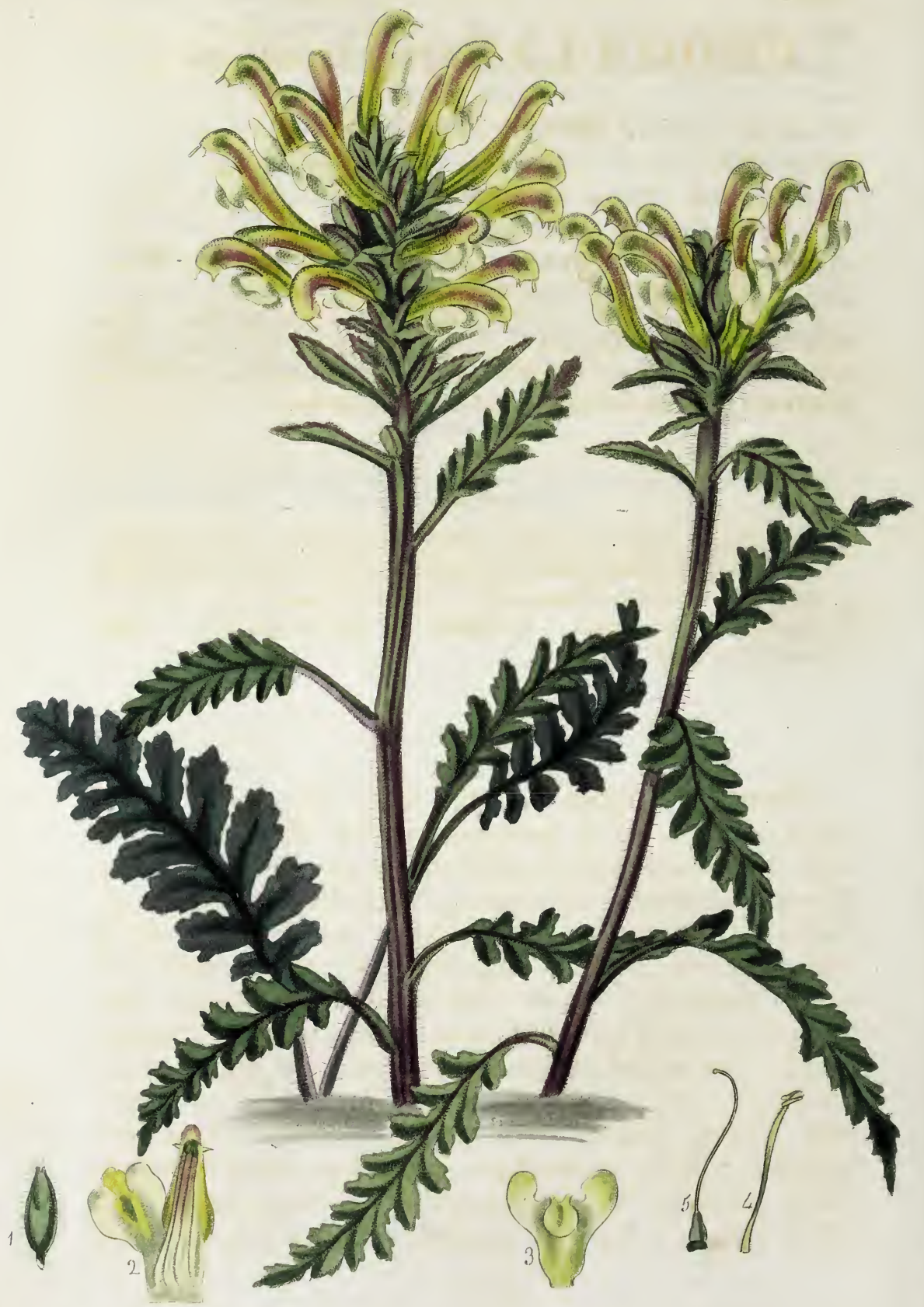




\title{
PEDICULARIS canadensis.
}

\author{
Canadian Pedicularis.
}

Natural Order. Scrophularine. Brown prodr. 433. Sect. II. Stamina 4 antherifera.

PEDICULARIS. Calyx 5-fidus. Corolla ringens. Capsula bilocularis, mucronata, obliqua. Semina tunicata. Folia opposita aut alterna, simplicia aut sapiùs pinnata; flores oppositi aut alterni, bracteati, spicati terminales.

P. canadensis, caule simplici, foliis pinnatifidis inciso-dentatis, capitulo basi folioso hirsuto, corollis galea setaceo-bidentata, calycibus deorsum truncatis. Pursh fl. amer. 2. p. 425.

Pedicularis canadensis. Willden. sp. pl. 3. p. 211. Pers. syn. 2. p. 153.

Perennial. Stems several from the same plant, erect, simple, of a purplish colour, thickly clothed with soft white hairs, particularly on the upper part. Leaves alternate, lanceolate, pinnatifid, hairy : segments on the lower ones incised, or deeply toothed with bluntish rounded segments or teeth, which are again toothed; upper leaves more shallowly and sharper toothed with numerous small teeth. Petioles deeply channelled on the upper side, and rounded on the lower, hairy. Flowers in a short spike, or head, pale yellow, tinged with purple. Bractes leaf-like, toothed, villous at the base, the upper ones shortest. Calyx inflated, truncate downwards, emarginate, angular, villous. Corolla ringent: helmet flat, toothed 
near the point with 2 sharp setiform teeth; lower lip 3-lobed, side lobes ovate-rounded, erect, the middle one reflexed. Stamens 4, inserted in the tube, 2 rather longer than the others; the 2 longest filaments are hairy, the others smooth. Style smooth, exserted, terminated with a small capitate stigma.

A native of North America, from whence plants of it were received last Autumn, by Mr. Colvill, from one of which our drawing was made the beginning of May. We planted them in a mixture of sandy loam and peat, principally the latter; and they are now in a flourishing state, and appear likely to increase at the root. Pursh mentions it as growing in woods and meadows, from Canada to Carolina; and it appears to us to be fond of moisture, and to prefer a shady situation.

1. Calyx. 2. Corolla spread open, to show the insertion of the stamens, and the 2 teeth on the upper part of the helmet. 3. Back view of the lower lip, showing the reflexed middle lobe. 4. Stamen detached, showing the hairy filament. 5. Germen, Style, and Stigma. 


\section{.}

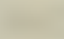

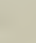

n

. 


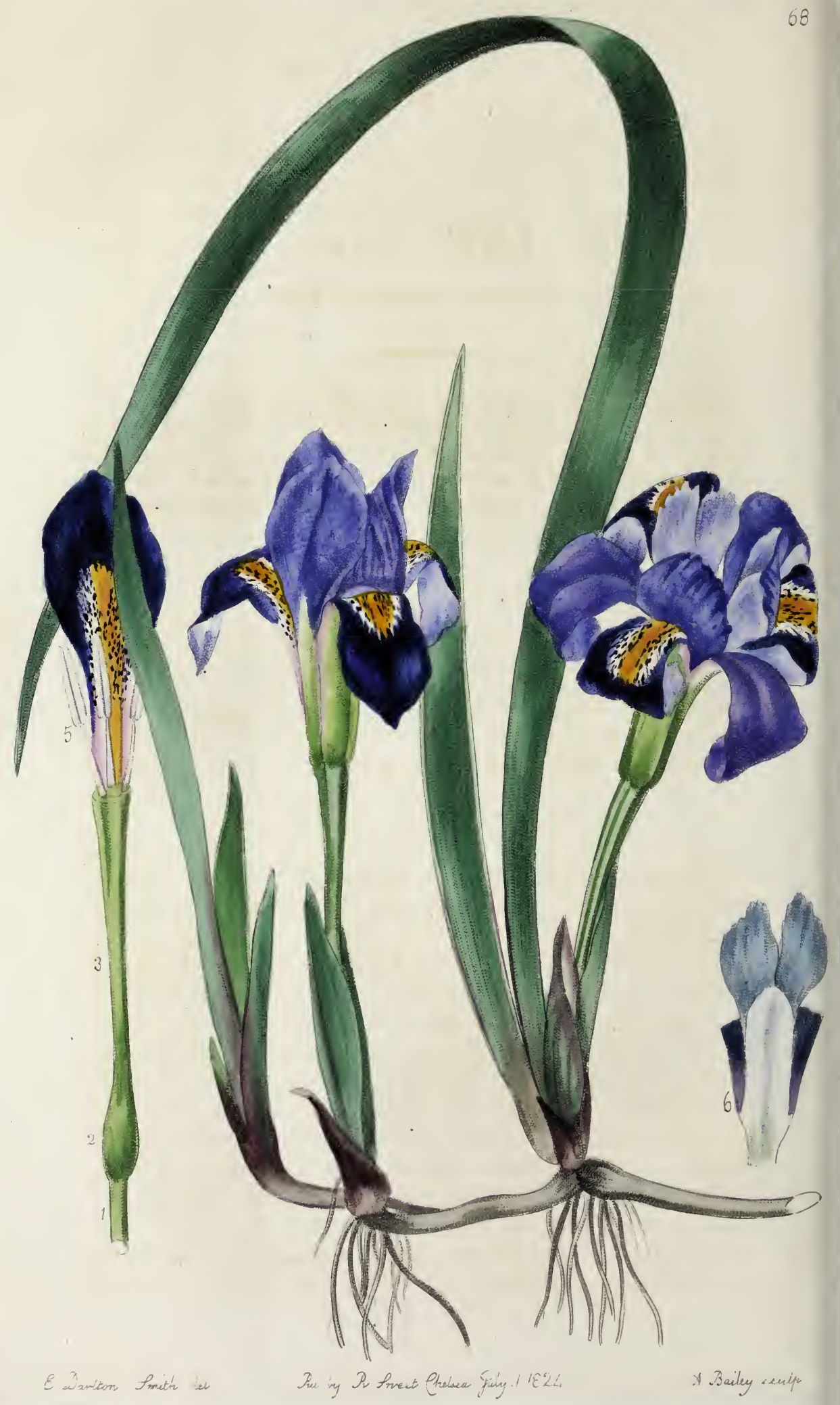




\section{8}

\section{IRIS verna.}

\section{Vernal American Iris.}

Natural Order. IRIDEA. Brown prodr. 302.

IRIS. Perianthium 6-partitum magnum : laciniis 3 alternis rectis; 3 alternis reflexis intùs barbatis aut imberbibus basi staminiferis. Stylus brevis; stigmata 3 petaloidea, oblonga, magna, staminibus incumbentia, sulco longitudinali nectarifero marginato suprà exarata.

I. verna, imberbis, acaulis, uniflora, foliis lineari-ensiformibus rigidis acutis glaucescentibus, perianthii laciniis subæqualibus, capsulis obsolete trigonis.

Iris verna. Mich. $f$. amer. 1. p. 22. Willden. sp. pl. 1. p. 235. Pers. syn. 1. p. 53.

Iris verna? Nutt.gen. amer. 1. p. 23.

Roots scarcely tuberous, creeping, reddish. Leaves radical, linearly-ensiform, rigidly coriaceous, acute, margined, slightly glaucous, tinged with red at the base; in our plant, a foot in length. Scape 1-flowered, sessile, or nearly so, sheathed at the base with short leaf-like bractes. Germen attenuated, slightly triquetrous. Tube of the Perianthium slightly but bluntly triangular, about 2 inches long; lacinia jointed on the tube, inner and outer divisions nearly equal, with long slender ungues, oblong-obovate, of a beautiful bright blue, the 3 exterior marked with an oblong orangeyellow stripe, edged and spotted with black, and having a central slightly raised, scarcely villous line; inner ones of one colour, at first connivent, afterwards spreading flat like the outer ones. Stamens 3, inserted 
in the base of the laciniæ, at the summit of the tube. Style short. Stigmas 3, petal-like, linearly-oblong, deeply bifid and toothed at the edges, keeled inwards.

We think there can scarcely be any doubt but the present subject is the real I. verna, which has been so long a desideratum in our collections; it is certainly Mr. Nuttall's plant, though he describes the roots as tuberous, which ours scarcely is, but is more of a creeping nature. I. verna of Pursh is probably a different plant, though his description agrees pretty well with the present, except in the capsule being subrotund, which in ours is bluntly 3 -sided; the colour of the flowers is also said to be light blue, striped with purple; Mr. Colvill received plants of the present species, last Autumn, from North America, with some others, one of which is said to be the I. tridentata of Pursh, but it has not yet flowered.

In our opinion, the present species is by far the most beautiful of all the dwarf sorts, and appears to grow as freely as any of them, when planted in a rich light soil, flowering the beginning of May; it also possesses a considerable degree of fragrance, and may be increased by dividing at the root.

1. Peduncle. 2. Germen. 3. Tube of the Perianthium. 4. One of the outer laciniæ of ditto, showing the insertion of the stamen at its base. 5. The 3 Stamens. 6. Back view of the Stigma. 


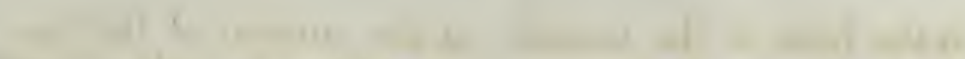
the

$$
\begin{aligned}
& \text { - } \\
& \text { and }
\end{aligned}
$$

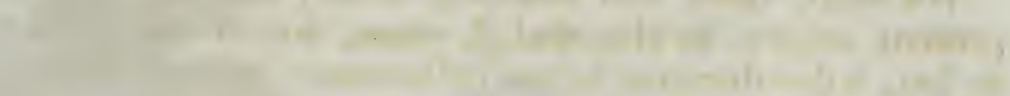$$
\text { - }
$$

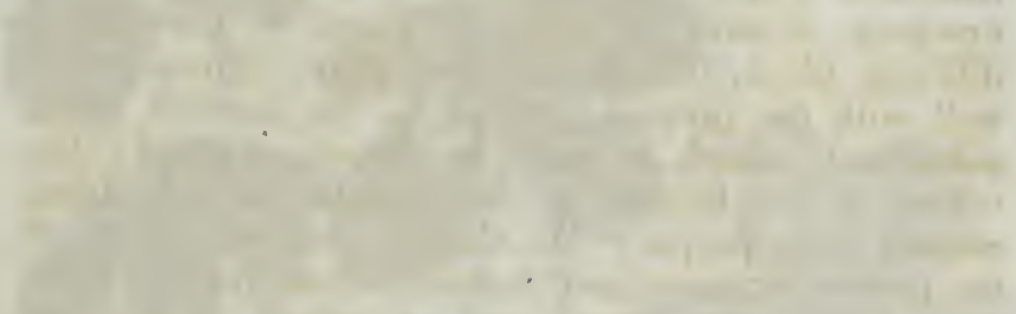

|

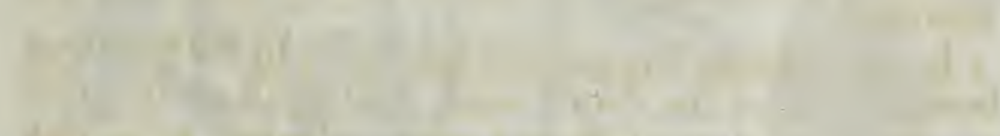

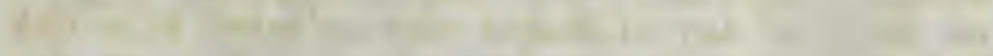

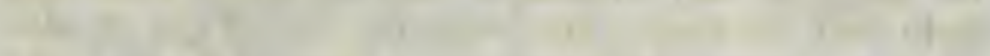

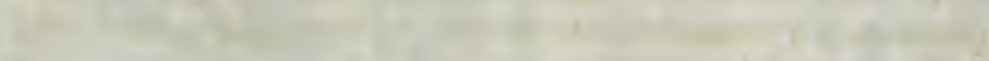
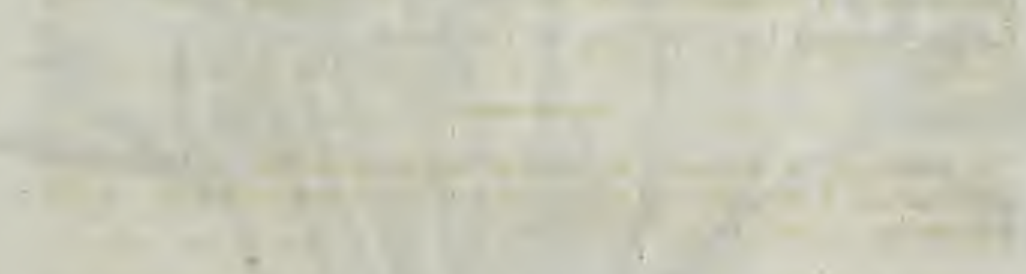


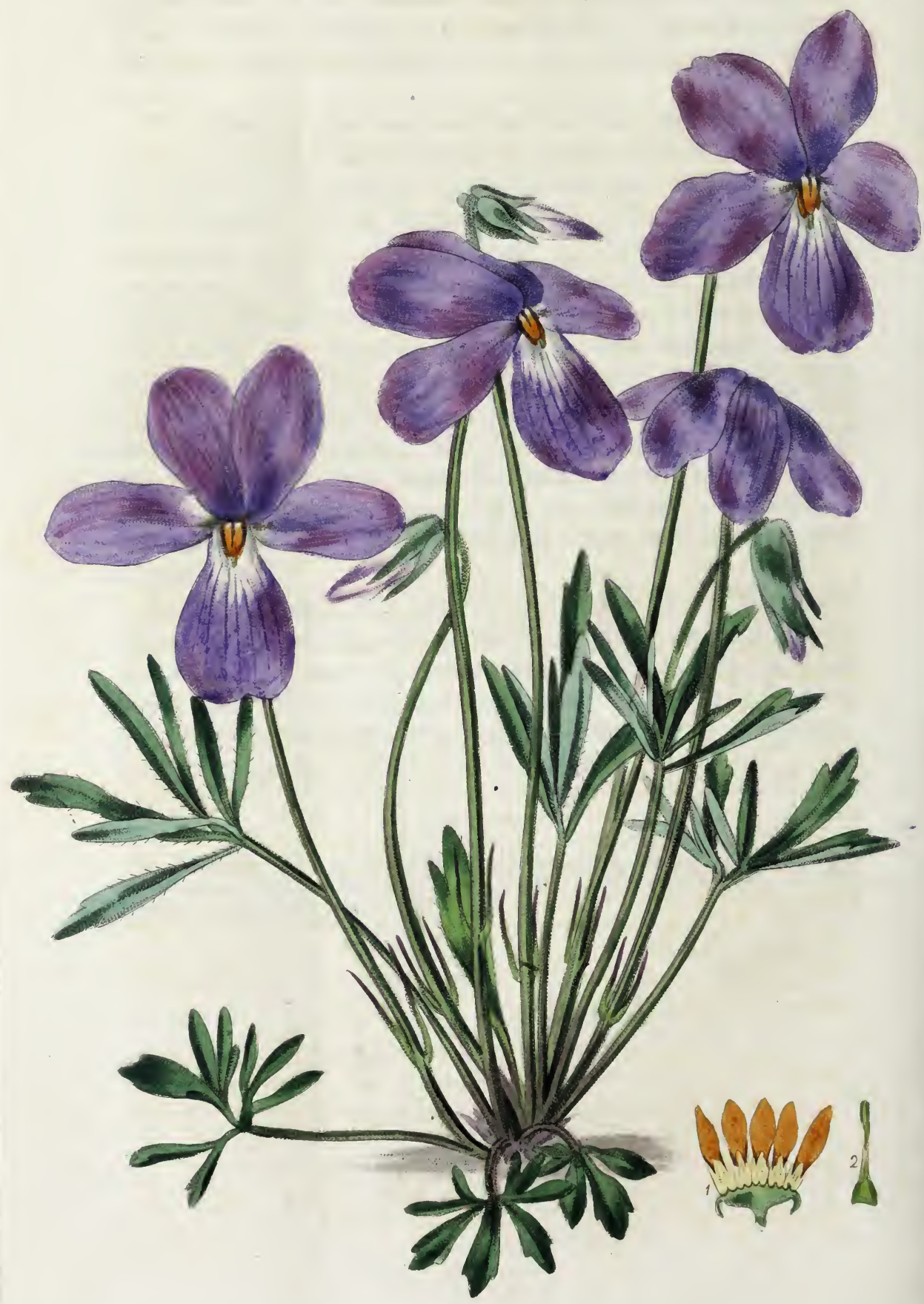




\section{9 \\ VIOLA pedata. \\ Cut-leaved Violet.}

Natural Order. Violariez. DC. prodr. syst. nat. 1. p. 287.

VIOLA. Calycis sepala inæqualia, omnia plus minùs deorsùm in appendices auriculæformes (è dilatationibus nervorum prodeuntes) producta, post anthesin erecta. Petala inæqualia, æstivatione convolutivâ, ungue trinervi; inferius deorsùm in calcar cavum plus minùs productum. Stamina approximata aut coarctata (nec coalita) ad apicem dentium tori pentagoni 5-dentati inserta. Filamenta basi dilatata oblonga vel triangularia, antheras demissiùs gerentia; lobi antherarum basi divergentes, stamina 2 anteriora dorso appendices varias nectariferas in calcar intrantes gerentia. Ovarium nunc superum, nunc basi toro concavo cinctum et ided semi-inferum. Valvula capsulæ elasticæ post maturationem contractæ semina ejicientes; semina horizontalia manifestè carunculata, plus minùs ovoidea et nitida. Embryo oblongus, radicula teretiuscula, cotyledones sæpiùs oblongo-orbiculatæ planiusculæ radiculâ vix longiores.-Herbæ plerùmque perennes, rarissimè annuc, nunc caule brevissimo vel subterraneo, unde acaules dicte, nunc caulescentes vel suffrutices parvi; folia alterna marcescentia; pedunculi solitarii axillares uniflori, 2-bracteolati non articulati, apice reflexi; flores cernui; folia seminalia oblonga ovatave, petiolata; primordialia opposita, sed rarò coëtanea. DC. loc. cit. p. 291 .

Sect. I. Nomimium. Stigma rostratum, foraminulo ad extremitatem rostri sito; rostrum plus minùs recurvum, nunc deorsùm marginatum et tunc planiusculum et obliquum, nunc absque margine et tunc deorsùm convexiusculum. Stylus ab apice ad basin attenuatus. Stamina oblonga approximata. Torus planiusculus. Capsula sæpius trigona. Semina 15-27. Folia seminalia sæpe obovata vel oblonga.

§. I. Stigmatibus apice depressis, aut deorsùm in orbem marginatis ; caulibus subnullis.

* 'Iruncis radiciformibus (Rhizomatibus?) dentatis plìs minùsve carnosis, sapius obliquis. DC. loc. cit.

V. pedata, stigmate incrassato hinc oblique truncato; rostro brevissimo, foliis pellucido-punctatis palmatisectis, stipulis pectinatim laceris longe adhærentibus, petalis omnibus glabris. DC. loc. cit.

Viola pedata. Willd. sp. pl.1. p.1160. Pursh. fl. amer. 1. p. 171. Nutt. gen. amer. 1. p. 145. Botan. magaz. 89. Andrews reposit. 153. Pers. syn. 1. p. 251. 
Stemless. Leaves pedate, many parted: segments linearly lanceolate or slightly wedge-shaped, entire or toothed near the point, attenuated to the base, pellucidly-punctate with numerous small dots, finely ciliate. Petioles gradually tapering upwards, furrowed with 2 small channels on the upper side, and angular on the lower. Stipules ciliate or lacerate, taperpointed, joined to the base of the footstalks. Peduncles bearing 2 subulate taper-pointed keeled bractes a little above the base, furrowed, sometimes not so long, at other times longer than the leaf. Calyx of 5 sepals, slightly unequal, lanceolately subulate, taperpointed, eared at the base. Petals 5, alternating with the sepals, oblongly abovate, spreading, the 2 upper ones slightly recurved, the lower one broadest, slightly emarginate, all of them smooth, (not bearded,) of a light purplish blue, with scarcely darker veins; the lower one with a light mark near the base. stamens 5 , inserted in the receptacle, alternate with the petals : anthers 2-celled, joined to the filaments by their back ; filaments a little dilated at the base, and terminating above the anthers in a dry blunt yellowish membrane. Germen smooth. Style smooth. Stigma large and thick, compressed at the sides, obliquely truncate, beaked, the small beak fixed in a little pit near the point.

Several strong plants of this beautiful species of Violet were received, last autumn, by Mr. Colvill, from North America; from one of those our drawing was taken last spring; it is a very variable plant, different individuals varying very much in the breadth and division of their leaves, and also in the length of their peduncles. It appears to thrive well with us in a sandy peat soil, where it makes a very handsome appearance with its divided leaves and large blue flowers. It may be increased by seeds, or separating at the root.

1. The 5 Stamens spread open, to show the insertion of the anther to the back of the filament, the filament terminating beyond it in a dry yellowish membrane. 2. Germen, Style, and Stigma. 



\title{
PAENIA lobata.
}

\author{
Lobed-leaved Paony.
}

Natural Order. Ranunculacea. DC. syst. v. 1. p. 127.

Trib. V.? PEONIACEA. Antheræ introrsæ ; an ordo proprius. DC. prodr. 1. p. 64.

PAEONIA. Supra fol. 19.

Sect. II. P PEON. Caulis herbaceus. Discus vix aut non expansus et carpella imâ basi tantùm circumdantia.

P. lobata, herbacea, carpellis tomentosis erectiusculis, foliorum segmentis glabris decurrentibus pinnatipartitis apice trilobatis. DC. prodr. 1. p. 66.

Pæonialobata. Desf. cat. hort. par. 126. DC. syst. 1. p. 39.

Stem erect, from 18 inches to two feet high, smooth. Leaves ternate: leaflets pinnatifid, smooth or slightly pubescent underneath, with a few small hairs scattered here and there on the nerves, decurrent: segments ovate or oblong, bluntish, generally 3 -lobed or toothed, but sometimes entire; nerves underneath much branched, prominent. Petioles smooth, channelled on the upper side, and rounded on the lower. $\boldsymbol{P e}_{\boldsymbol{e}}$ duncle furrowed, gradually thickening upwards. Involucre leaf-like, bractes 3-parted or entire, lanceolate, acute. Calyx of 5 sepals: outer ones longest and narrowest, acute : inner ones orbicular, concave, edged with red. Petals 8, bright red, inclining to scarlet, with a white mark on one of the outer ones, nearly orbicular, hollow or cupped inward, slightly notched at the edges, outer ones largest. Stamens numerous, surrounding the germens: filaments smooth, red at 
the base, and pale upwards, inserted in the base of the anthers. Germens 2 or 3, erect, or slightly curved inwards, thickly clothed with a shining white silky tomentum. Stigmas red, crested, undulate.

Our drawing of this handsome species of Pæony was taken at the Nursery of Messrs. Whitley, Brames, and Milne, last summer; they had imported it from France, as the P. lobata of M. Decandolle, which we think there is no doubt but it really is, though some people think otherwise, the leaves being slightly hairy, whereas he describes them as smooth; in the specimens that we examined, the young leaves were slightly hairy, but the older ones were quite smooth ; in every other respect it agreed exactly with the description in his Prodomus, where he has divided from it the P. Russi, which, in his former work, he had given as a synonym; this is now ranked with the pubescent species, and we believe it to be the plant received from the Botanical Garden at Liverpool as a variety of $P$. arietina, with which it agrees in the character of its recurved germens.

The present plant is at present very scarce in the collections about London, and is consequently rather expensive ; it is as hardy as any of the common sorts, and grows freely in the common garden soil. It may be increased by dividiug at the root.

1. Segment of one of the lower leaves, showing its lobed point. 2. Stamens detached, showing the red base of the tilaments. 3. Germens, showing their dense silky down, terminated with their red crested stigmas. 



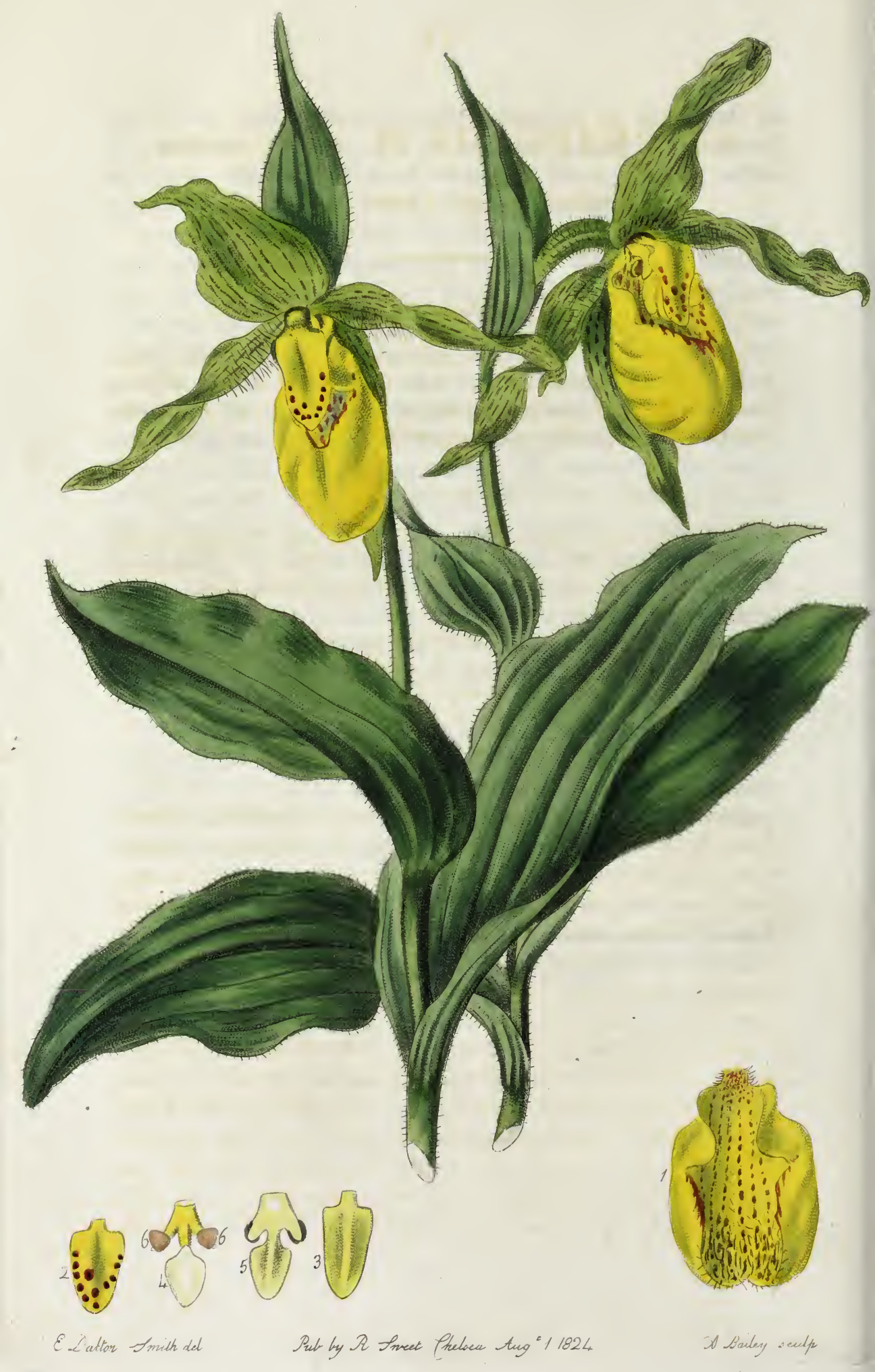




\title{
CYPRIPEDIUM pubescens.
}

\author{
Yellow Downy Ladies' Slipper.
}

Natural Order. ORCHides. Brown prodr. 309.

Sect. VI. DIANDRE. Stamina 2 antherifera.

CYPRIPEDIUM. Perianthium 4-phyllum, patens : foliola 2 antica sæpius connata. Labellum ventricosum, inflatum (nunc saccatum.) Colımna postice terminata lobo petaloideo (stamine sterili,) antheras distinguente.

C. pubescens, caule folioso, lobo styli triangulari-oblongo obtuso, perianthii foliolis exterioribus ovato-oblongis acuminatis: interioribus linearibus contortis basi intus subbarbatis, labello nervoso foliolis breviore compressu.

Cypripedium pubescens. Willden. sp. pl. 4. p. 143. Hort. berol. 1. t. 13. Pers. syn. 2. p. 525. Hort. Kew. ed. 2. v. 5. p. 221. Pursh fl. amer. 2. p. 594.

Cypripedium flavescens. Redoute liliac. 20.

Stems several from the same root, upright, striate, densely pubescent. Leaves 4 or 5, alternate, sessile, clasping the stem at the base, spreading, ovate, acute, more or less waved, point slightly twisted, longitudinally nerved and plaited, furrowed on the upper side, densely pubescent. Flowers 1 to 3 , nodding. $P e-$ duncle scarcely as long as the leaf, densely pubescent. Bracte 1, straight, leaf-like, ovate, taper-pointed, shorter than the leaflets of the perianthium. Pedicle short, enclosed in the bracte. Germen angular, curved, not twisted, densely pubescent. Leaflets of the Perianthium of a greenish yellow, more or less spotted with brown: 2 outer ones ovate, acuminate, upper one erect, a little twisted, lower one dependent, straight, longer than the labellum; inner ones longer, broadly 
linear, spreading, a little deflexed, twisted, points acute, bearded inside at the base with a tuft of white hairs, but much less so than C. parviflorum; outside densely pubescent. Labellum yellow, ribbed, mouth edged with brown, inside elegantly spotted in purple circular lines, bearded at the bottom. Column lobe triangularly oblong, obtuse, smooth, channelled on the upper side, and concave near the point, keeled and channelled underneath, yellow, spotted with brown. Style yellowish white: middle lobe triangularly oblong, obtuse; side ones short, lanceolately cuneate, bluntish, shorter than the anthers. Authers 2, nearly orbicular, attached to the side lobes of the style. Pollen waxy, yellow.

The plant from which our drawing was taken, at the Nursery of Mr. Colvill, was received last autumn from North America; it was planted in a pot of very sandy red loam, where it flowered very strong in the beginning of June. The plants of this genus, as well as of many other Orchideous genera, are at present supposed to be very difficult to cultivate; but we hope, before long, to be able to give directions for cultivating them, as well as any other plants; a great many of them are fond of the shade of trees, which should be imitated as much as possible in the cultivation of them. Pursh mentions the present species as growing on sunny fertile hills, among small trees and bushes, generally in rocky situations, from Pennsylvania to Carolina. Introduced into this country in the year 1790, by Sir J. Banks ; but still continues scarce, as it is so liable to perish.

1. Labellum. 2. Front view of the Column lobe. 3. Back view of ditto. 4. Front view of the lower lobe of the Style. 5. Back view of ditto, showing the edges of the anthers attached to the 2 npper lobes. 6 . 6 . The 2 side lobes with the anthers attached to them, front view. 


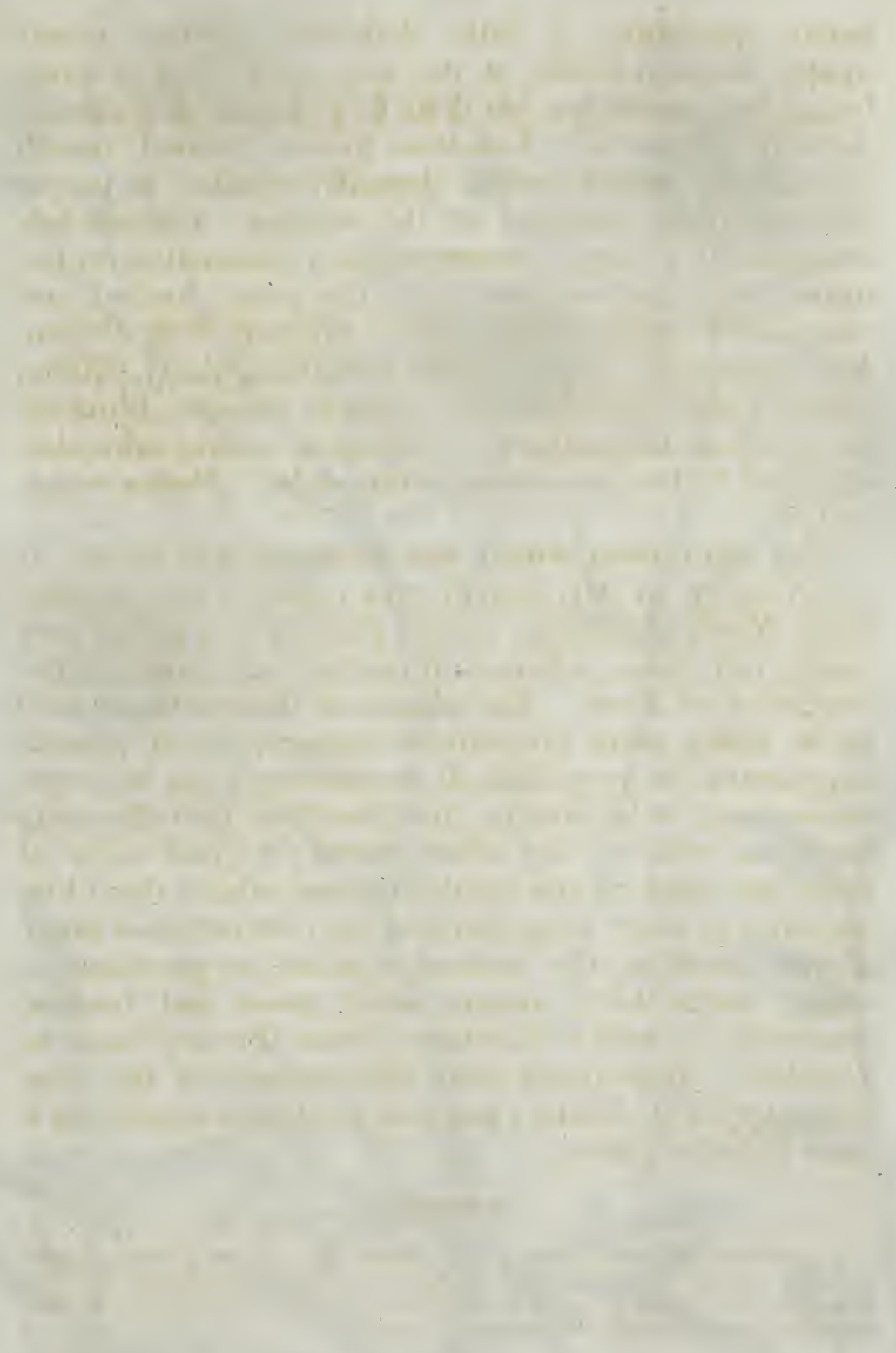




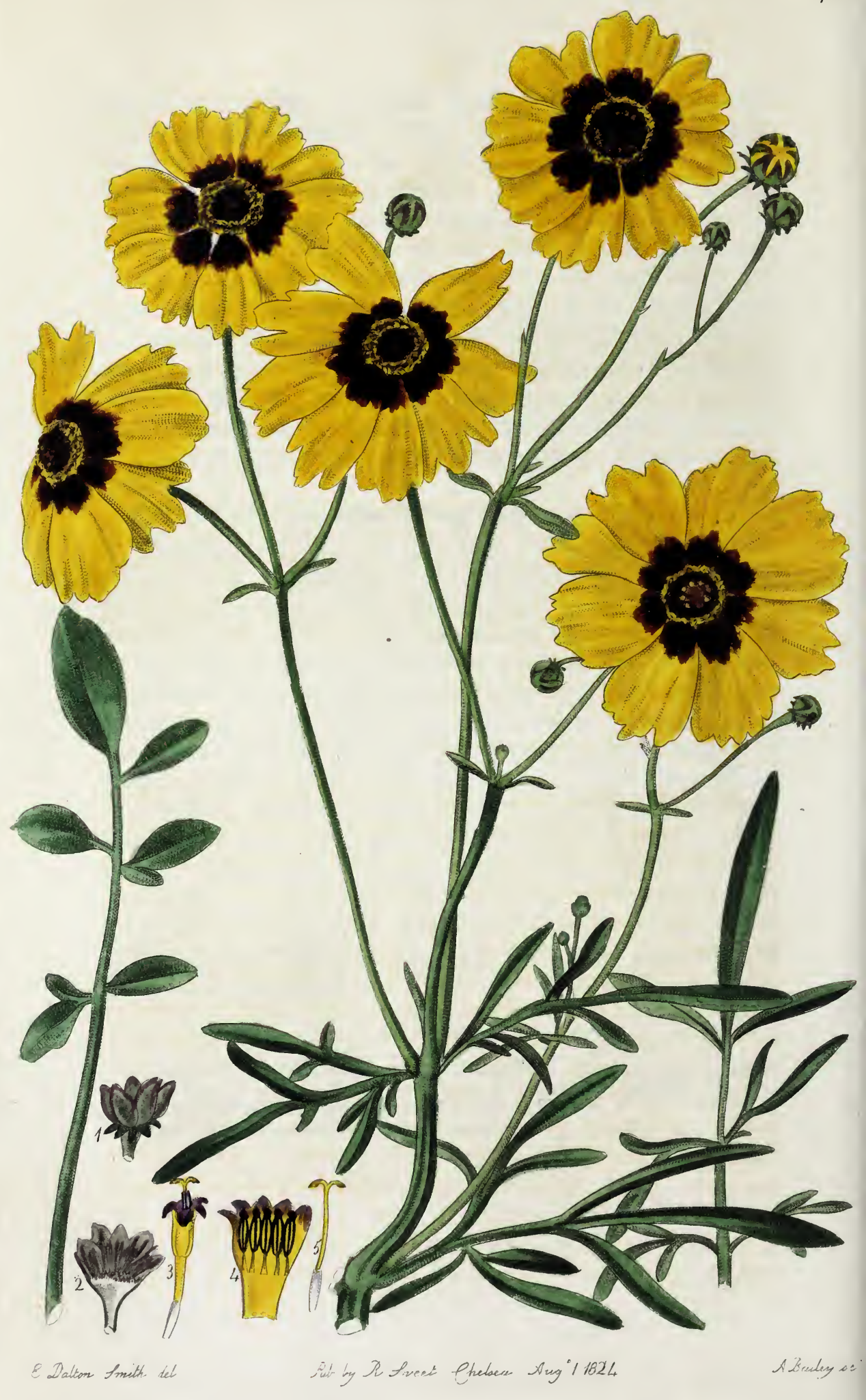




\title{
COREOPSIS tinctoria.
}

\author{
Dyeing or Arkansa Coreopsis.
}

Natural Order. Сом Posite. Adanson fam. 2. 103.

Sect. V. HELIANTHEA. Kunth Synops. 2. p. 468. COREOPSIS. Supra fol. 10.

C. tinctoria, foliis oppositis pinnatisectis glabris : inferioribus foliolis ovatis obtusis integris bifidisve; superioribus linearibus obtusis subdivisis, floribus ramoso-paniculatis, foliolis involucri exterioribus brevissimis, akeniis nudis emarginatis.

Coreopsis tinctoria. Nuttall in the Journal of the Academy of Natural Science of Philadelphia for 1821. p. 144. Barton Flor. N. Amer. vol. 2. f. 45.

Calliopsis bicolor. Hort. germ.

Annual. Stem erect, much branched, 2 to 5 feet high. Leaves opposite, somewhat succulent, smooth, at first simple and ovate, the next pinnately parted, with ovate, obtuse leaflets, which are generally entire, but sometimes 2-cleft: upper ones also pinnate or bipinnatifid, the leaflets or segments linear, obtuse, entire or pinnatifid, the terminal one much the longest. Flowers paniculately branching, terminating the branchlets by twos or threes. Involucre of $\mathbf{2}$ series, generally 8 in each : outer leaflets very short and small, lanceolate, obtuse, of a bright green: inner ones much larger, oblongly ovate, membranaceous, bluntish, of a brownish purple. Receptacle convex, paleaceous, warted : chaff filiform, purple, longer than the florets, deciduous. Rays about 8, 3 or 4-lobed, sterile, oblongly obovate, of a bright golden yellow, with a dark purple spot near the base, which causes an elegant 
dark circle round the disk. Florets of the disk numerous, fertile, tubular, 5-toothed. Stamens 5: filaments distinct: anthers connected, of a dark brown, their points exserted. Pollen orange-coloured. Style smooth, longer than the stamens. Stigmas 2, purple, recurved. Seed small, blackish, emarginate, curved, naked at the summit.

" Habitat. Throughout the Arkansa territory, to the banks of the red river, chiefly in the prairies, which are subjected to temporary inundation, flowering from June to October." Nuttall loc. cit.

This beautiful annual is of recent introduction from North America, and is a valuable acquisition to our collection of hardy annuals, as it appears to be of very free growth, and thrives well in the conmon garden soil. The seeds may be sown in pots, in a hot-bed frame, or in the green-house, and from thence be planted into the open borders; or it may be sown in the open ground, the latter end of March, or beginning of April ; but the plants raised in the latter way will not flower so early as the others. If sown in rich soil, the plants will attain the height of 4 or 5 feet; in poorer soil they will be shorter.

We received seeds of the present species from Germany this Spring, under the name of Calliopsis bicolor, from which we have raised a great many plants; we are also obliged to Professor Treviranus for others sent under the name that we have adopted.

Our drawing was taken from a plant in the Nursery of the late Mr. James Lee, of Hammersmith ; our description from one at the Apothecaries Company's Garden at Chelsea.

1. Capitulum cut through the middle, showing the leaflets of the Involucrum. 2. Inner view of the same, showing the chaffy receptacle. 3. Floret of the disk. 4. The same split open, to show the distinct filaments, and connected anthers. 5. Germen, Style, and Stigma. 


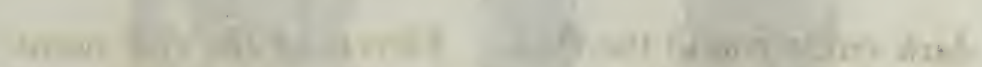

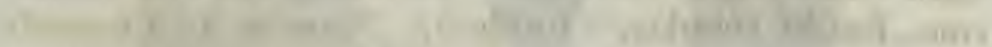

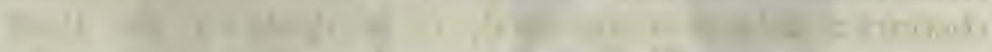

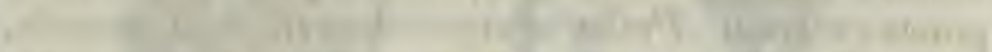
and

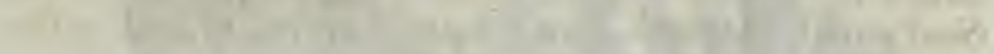

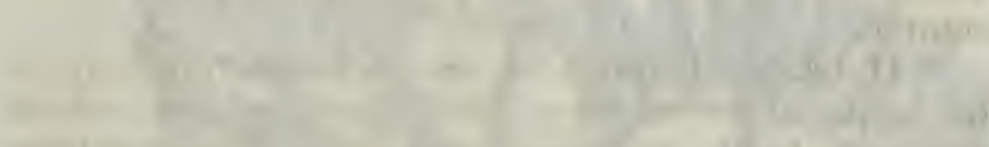

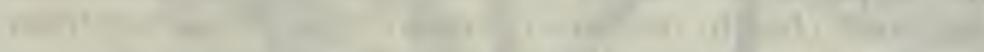

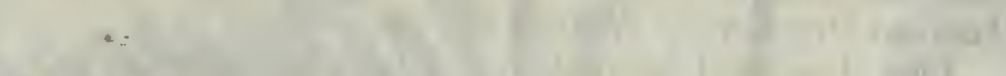

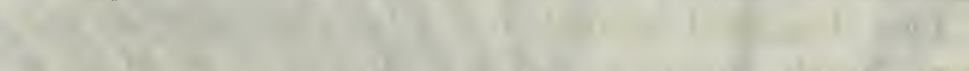

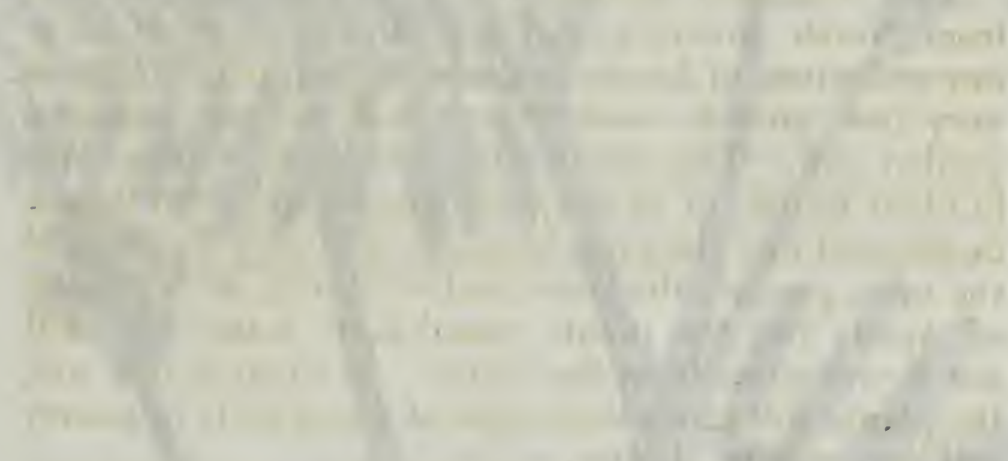

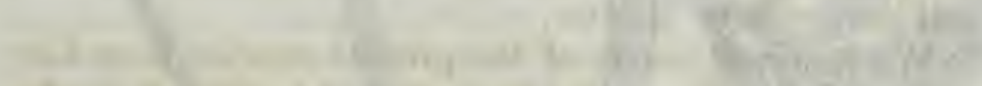

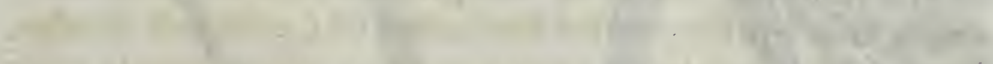

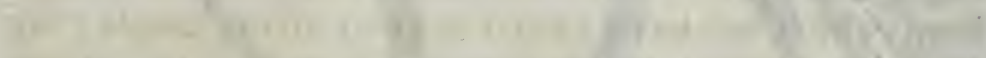

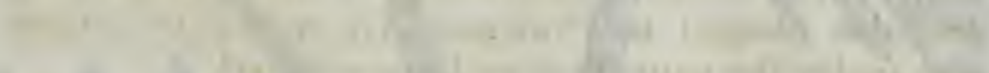

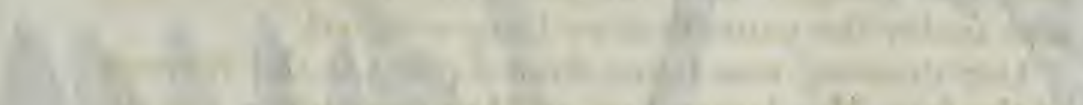

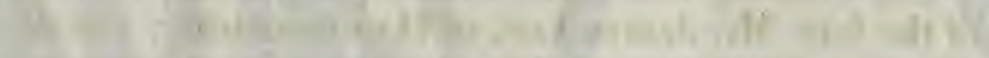

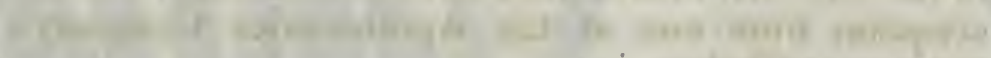

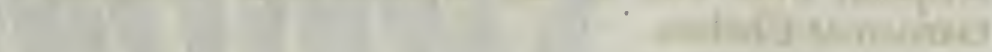

\section{$-6$.}
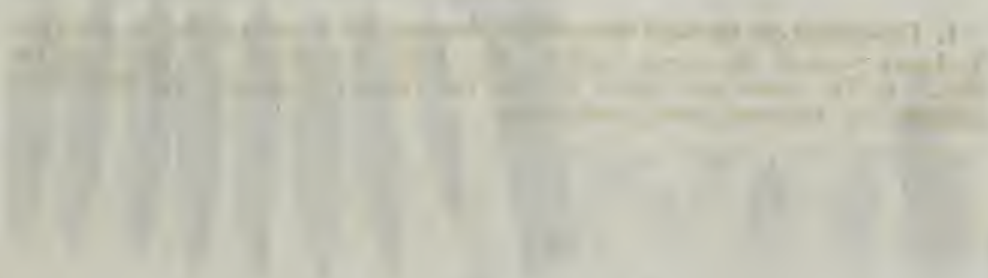


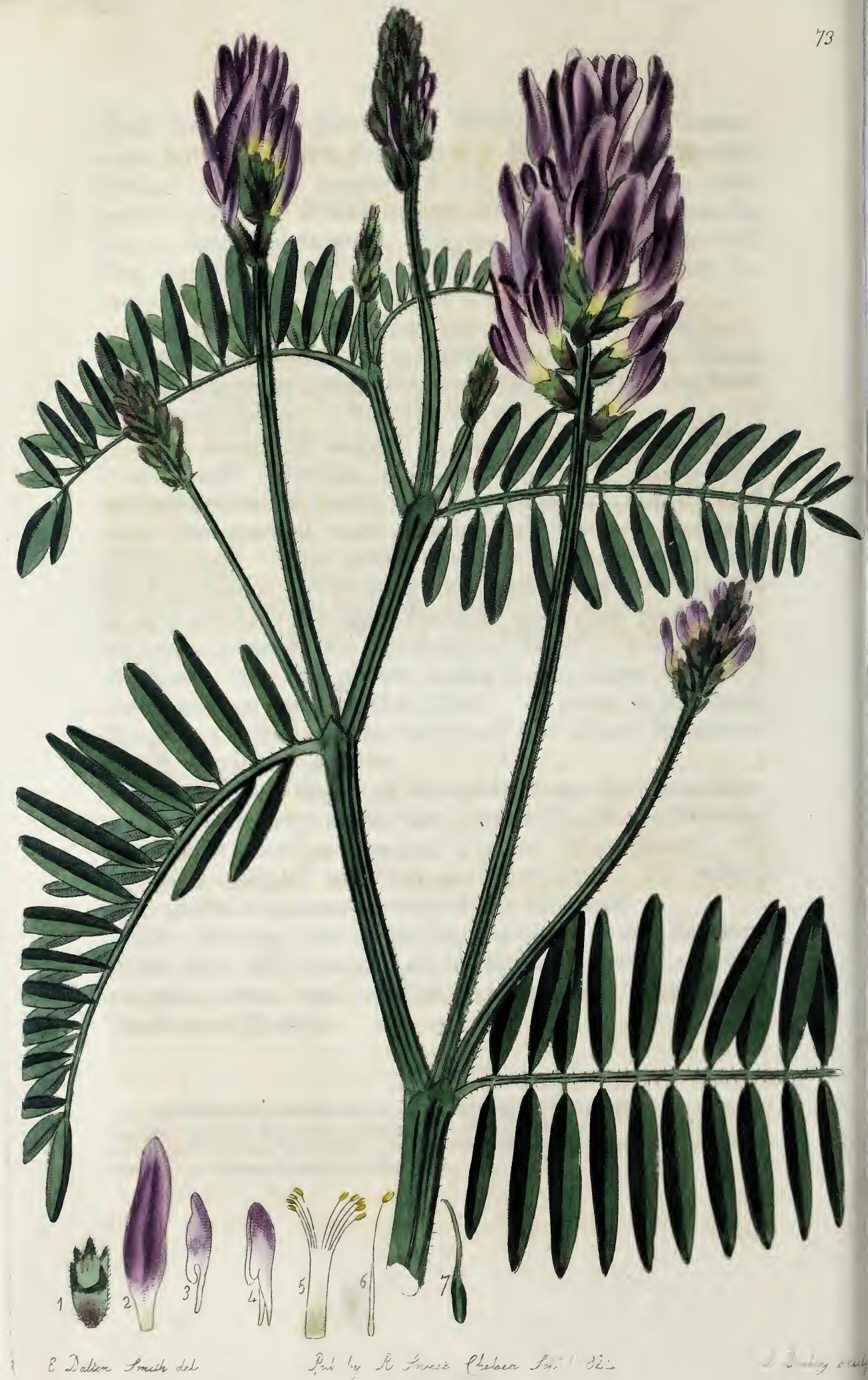




\section{ASTRAGALUS tenuifolius.}

Narrow-leaved Milk-vetch.

Natural Order. Leguminos A. Juss. gen. 345.

Div. VI. (PAPILIONACEAE.) Corolla irregularis papilionacea. Stamina decem diadelpha. Legumen uniloculare (in Astragalo et Biserrulâ biloculare) bivalve. Herba aut frutices aut arbuscula, folia impari-pinnata. Juss. gen. 357.

ASTRAGALUS. Calyx tubulosus 5 dentatus. Vexillum alis et carinâ longius. Carina obtusa. Legumen biloculare, aut subbiloculare, sutura inferiore introflexa.

Suffrutices aut sapius herbæ erecte vel prostrata; folia in Astragalo T. herbaceo impari-pinnata, in Tragacantha T. suffrutescente abruptè pinnata petiolo communi spinceformi aceroso longo; stipulæ à petiolo distincta aut (in Tragacanthâ) adnata, interdum in unam eidem oppositam coalita ; flores glomerati aut spicati, axillares et terminales. Legumen forma varium. Juss. gen. 358.

A. tenuifolius, caulescens erectus, foliolis lineari-lanceolatis, spicis oblongis pedunculatis folio longioribus, vexillo alis duplo longiore. Willden. sp. pl. 3. p. 1270. Hort. Kew. ed. 2. v. 4. p. 362. non DC.

Astragalus linearifolius. Pers. syn. 2. p. 336.

Astragalus Onobrychis, angustifolius. DC. Astrag. p. 125.

Perennial. Stems several from the same root, erect, or when grown in shady situations subdecumbent, from 18 inches to 2 feet high, sulcate, and thinly clothed with a dark brown or black pubescence. Leaves pinnate; leaflets 12 or 13 pair, and terminated by an odd one, linearly lanceolate, bluntish, keeled underneath and channelled above, and clothed with a closepressed silky pubescence. Petioles channelled on the upper side, and rounded on the lower, clothed with 
short dark hairs, as are the peduncles and calyx. Stipules cordate, acute, membranaceous, surrounding the stem, not adhering to the petioles. Flower-spikes oblong, pedunculate. Peduncles axillary, simple, or in pairs, longer than the leaves, furrowed. Flowers crowded, of a rosy lilac. Bractes lanceolate, taperpointed, concave, keeled underneath, ciliate. Calyx tubular, 5-toothed, teeth short, erect, lanceolate, acute, the 2 upper ones shortest and deepest. Corolla papilionaceous; vexillum oblong, carinate, double the length of the wings and keel; ala, or wings, slenderly unguiculate, eared above the unguis; carina obtuse, also eared at the base. Stamens 10, diadelphous, 1: distinct, the others joined at the base with distinct points. Germen and Style smooth. Stigma slightly capitate.

A beautiful hardy perennial plant, a native of Siberia, and requires no other treatment than to be planted in the open border in the common garden soil, and to be kept free from weeds; in rich soil it will attain the height of 2 feet, in poorer soil it will be considerably less, flowering in July and August, and ripening its seeds, by which it is increased. Those may be sown early in Spring, either in pots, or in the open ground; and as soon as the plants are $\mathbf{2}$ or $\mathbf{3}$ inches in height, they may be planted where they are to remain, watering them occasionally if they require it, and shading them a little at first if the weather prove warm and dry.

Our drawing was taken from a fine plant in the Garden of the Apothecaries' Company, at Chelsea, in July last.

1. Calyx. 2. Vexillum. 3. One of the alæ, or wings, showing where it is auriculate. 4. Keel, showing its blunt point, and the ears above the unguis. 5. The 9 connected Stamens. 6. The distinct Stamen. 7. Germen, Style, and small Stigma. 



\title{
74
}

\section{IRIS hungarica.}

\author{
Sickle-leaved Hungarian Iris.
}

Natural Order. IRIDEA. Brown prodr. 302.

IRIS. Supra fol. 68.

I. hungarica, barbata, foliis ensiformibus glabris subfalcatis subæquantibus scapum multiflorum, spathis inflatis suprema biflora. Willd. enum. 1. p. 64.

Iris hungarica. Waldst. et Kitaib. luung. 3. t.226. Hort. sub. lond. p. 12.

Root large, tuberous. Leaves ensiform, smooth, generally falcate, nerved with numerous prominent nerves, taper-pointed, about equal with the manyflowered scape. Spathes inflated; sheaths 2, opposite, acute, keeled, inclosing the peduncle, germen, and tube. Peduncle short and thick, obsoletely 3 -sided. Germen bluntly 3-sided and 3-furrowed, smooth and glossy. Perianthium 6-parted, of a beautiful blue pur ple; tube an inch in length, bluntly 3 -gonal, 3-sulcate, smooth and glossy; outer lacinice narrowest, reflexed, densely bearded from the base to above the middle, and variegated near the base; inner ones broadly obovate, erect, connivent, or closing each other at the points, also variegated near the base. Stamens 3, inserted in the base of the laciniæ, about half the length of the stigmas ; filaments flat, smooth; anthers linear, attached to the filament a little above the base, nearly as long as the filaments; pollen white. Style short, acutely 3-cornered. Stigmas 3, petal-like, keeled 
inwards, points deeply cloven, acute and jagged by the sides.

This fine species of Iris is a native of Hungary, and is readily distinguished from most others by its falcate leaves; it is quite hardy, and thrives well in a rich light soil, flowering in May and June, and sometimes again in Autumn. It is not one of the strongest growing sorts, but is of middle stature, the leaves seldom exceeding a foot in height, and the flower stems are not so high ; but the flowers are large, and very showy, and several are expanded at the same time. The best method of increasing it, is by dividing the roots, but it may be also raised from seeds, which sometimes ripen; those should be sown as soon as ripe, either in pots, or in the open ground, transplanting them while quite young, that they may not miss their removal.

Our drawing was taken from a plant at the Nursery of Mr. Colvill, in May last.

1. The 3 Stamens inserted in the base of the laciniæ of the Perianthium. 2. One of the Stigmas, the 2 others cut off near the base. 

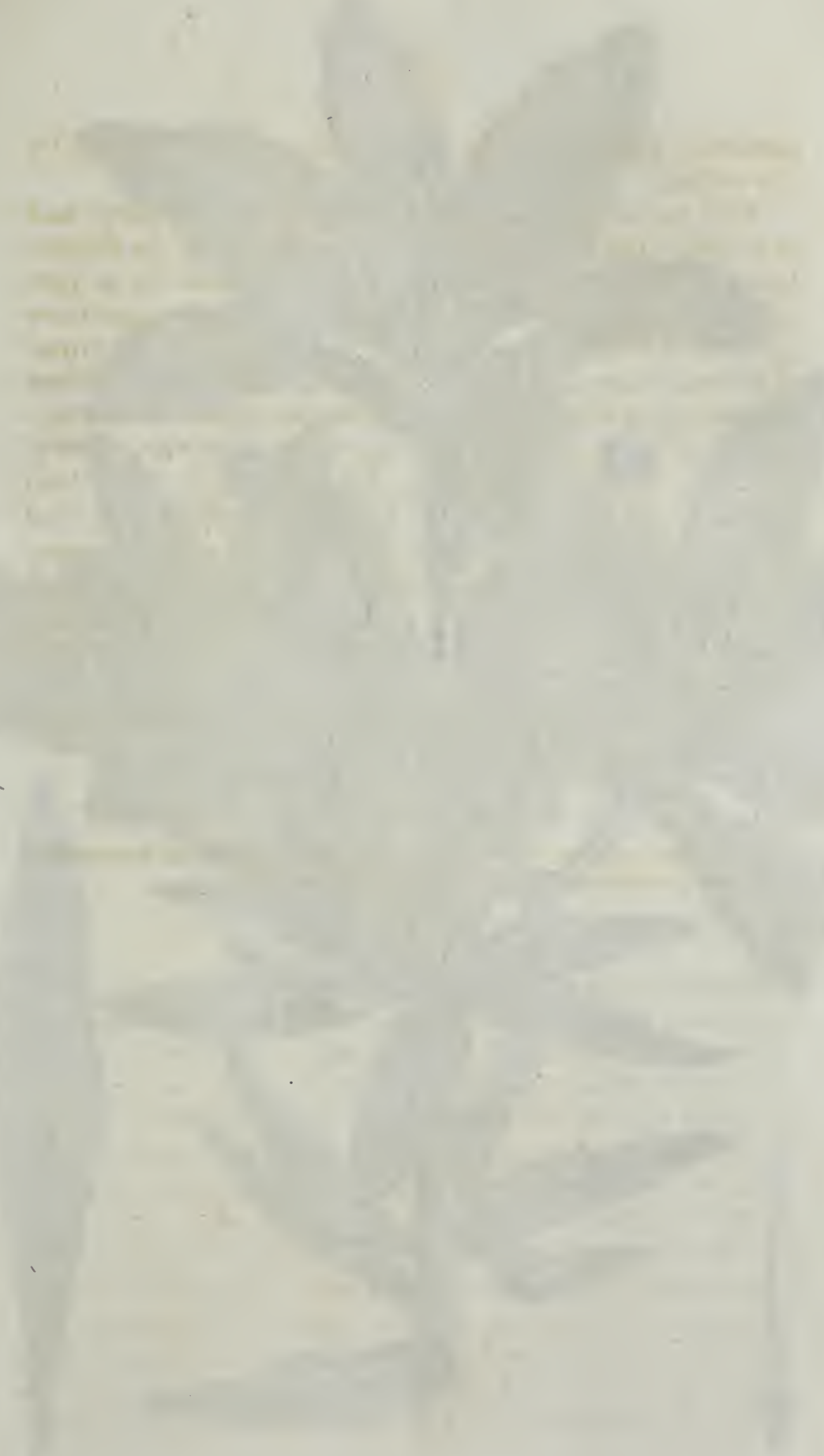


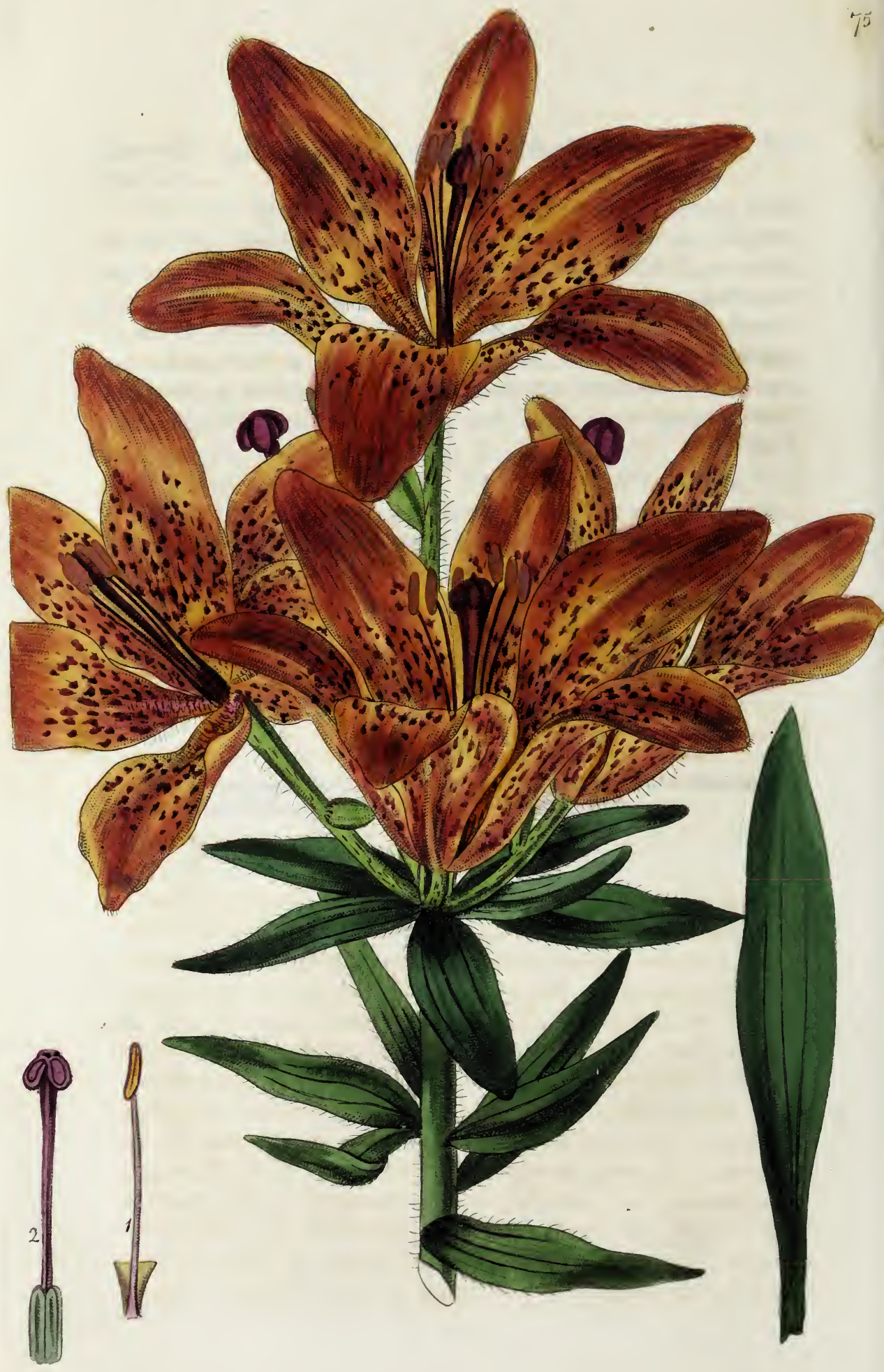




\title{
LILIUM spectabile.
}

\author{
Showy Siberian Lily.
}

Natural Order. TuliPACE

LILIUM. Perianthium 6-phyllum, petaloideum, campanulatum : foliolis rectis aut revolutis, basi conniventibus et sulco longitudinali nectarifero, nudo aut ciliato, exaratis. Stamina 6 stylo breviora. Capsula valvulis pilo cancellato connexis; semina plana. Radix tuberosa, basibus foliorum imbricata; caulis foliosus simplex; foliis alternis aut verticillatis; flores spathacei, spicati aut subpaniculati, in pluribus cernui.

L. spectabile, foliis subternis sparsisve linearibus subtrinerviis: superioribus margine subtomentosis, pedunculis tomentosis, corollis erectis intus scabris. Link enum. 1. p. 321.

Lilium pensylvanicum. Ker Bot. Mag. 872. non Pursh.

Lilium dauricum. Ker Bot. Mag. 1210. in note. Hort. sub. lond. p. 68.

Stem erect, from 1 to $\mathbf{2}$ feet in height. Leaves ternate, or scattered, linearly lanceolate, acute, faintly 3-nerved, striate; lower ones smooth and glossy, upper ones slightly tomentose, particularly the margins, which are fringed with wool. Flowers terminal, from 1 to 6 , in our specimen the latter number, umbellate, of an orange colour. Peduncles unequal in length, densely tomentose, often 1-leaved. Perianthium 6-leaved; leaflets between ovate and lanceolate, gradually attenuated to the base and point, in which it differs from L. bulbiferum, L. croceum, \&c. inside rough, warted, and spotted with black or dark purple. Stamens 6; filaments smooth, purple, attached to the base of the perianthium, and joined to the back of the anther. Style 
purple, 3-channelled, thickened upwards. Stigma clubbed, 3-sulcate.

We have adopted the name of Professor Link for the present species, the other names by which it has been already published, tending only to confuse; the present is the name adopted in the continental gardens, from whence we have often received seeds of it. But this must not be confounded with the L. spertabile of Mr. Salisbury, which is the L. Catesbai of other authors.

Our drawing was taken from a plant at the Apothecaries' Company's Garden, at Chelsea, in July last, where it was growing very strong in the open border. It is quite hardy, and thrives well in the common garden soil, flowering the latter end of June, or the beginning of July. It increases pretty freely by offsets from the bulbs; and it also ripens seeds, which should be sown as soon as gathered, as they then vegetate immediately. The L. croceum of Loddiges' Botanical Cabinet, is nearly allied to our plant, judging from the figure, but we think it is certainly distinct, and also from the L. croceum of Link.

1. One of the Stamens attached to the base of one of the leaflets of the Perianthium. 2. Germens, Style, and Stigma. 


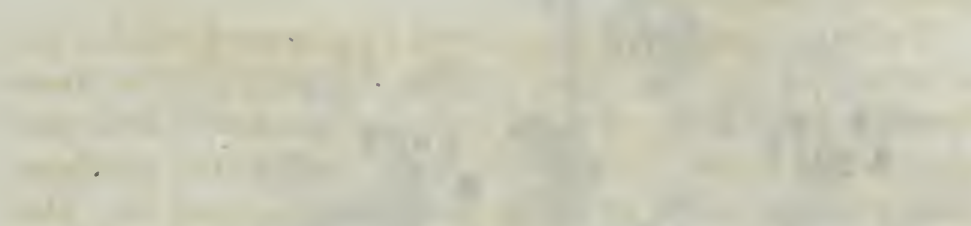

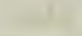

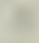

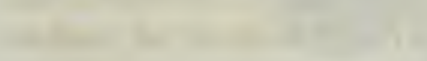

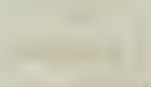

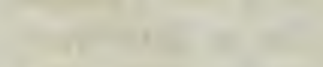
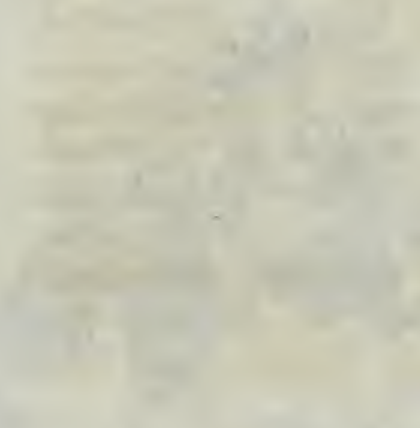

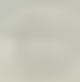
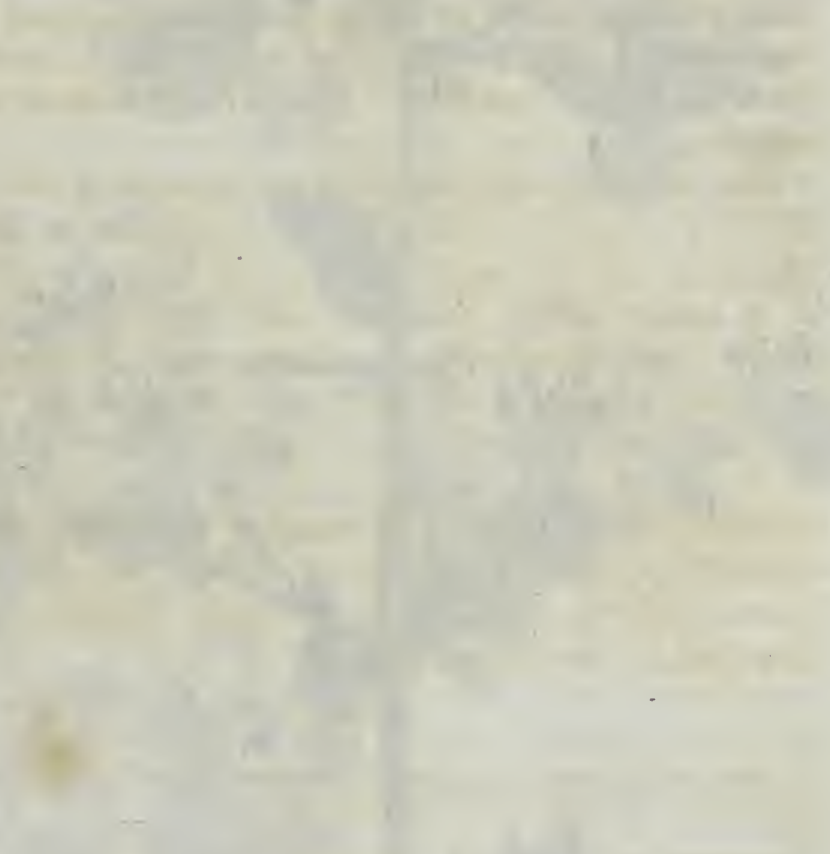


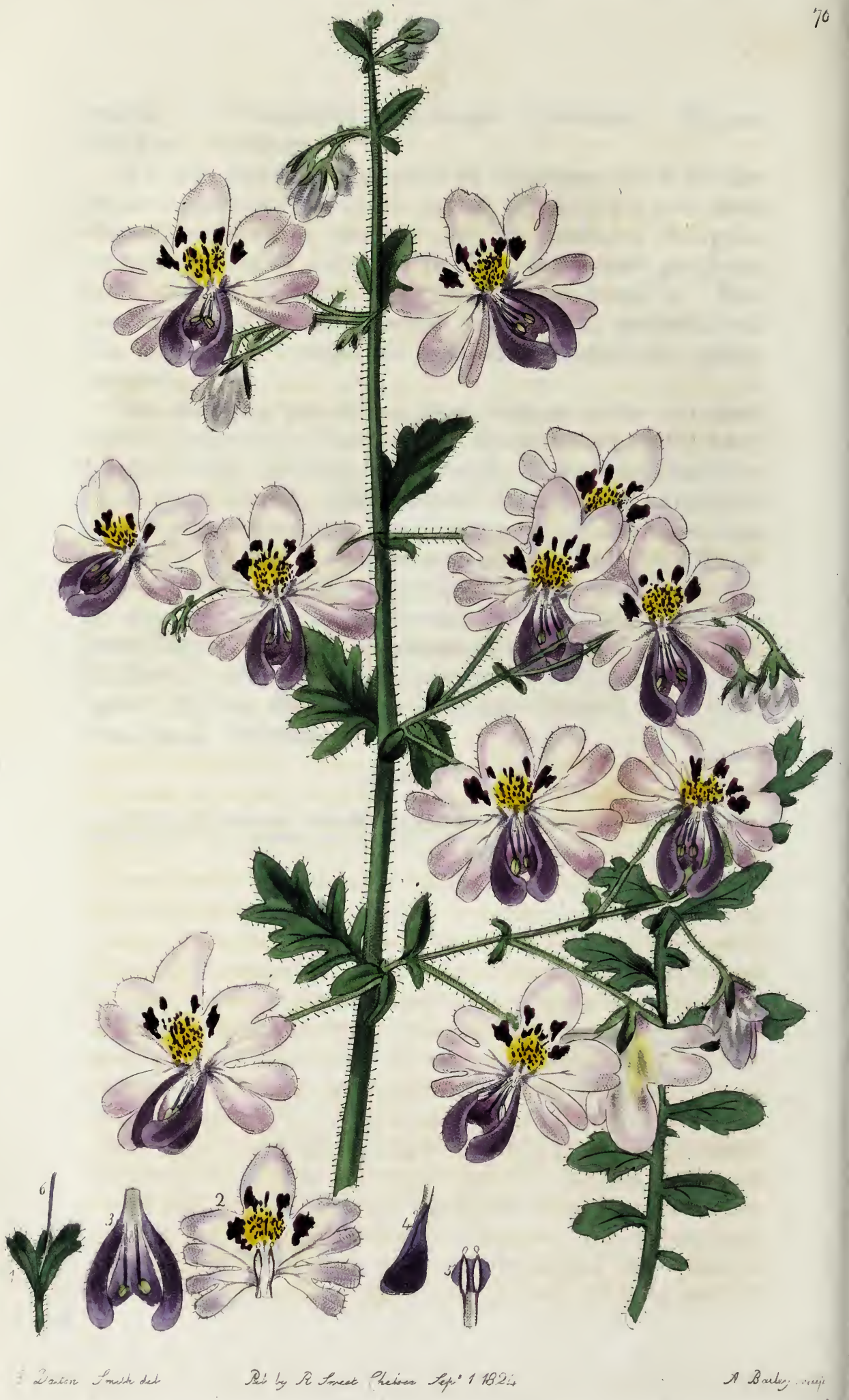




\title{
SCHIZANTHUS porrigens.
}

\author{
Spreading Schizanthus.
}

Natural Order. Surophularinde, Brown prodr. 433. Sect. I. Stamina duo antherifera. Capsula bilocularis. SCHIZANTHUS. Supra fol. 63.

S. porrigens, caule ramoso diffuso, foliis inferioribus interrupte pinnatis : foliolis oblongo-lanceolatis obtusis inciso-dentatis integerrimisve: superioribus oblongo-ovatis inciso-dentatis utrinque hirsutis, floribus paniculatis, racemis secundis.

Schizanthus porrigens. Hooker exot. flor. $t .86$.

Annual. Stem a foot to 18 inches in height, much branched, spreading in all directions; branches slender, thickly clothed with villous unequal spreading hairs, each tipped with a gland. Leaves thickly clothed with short hairs on both sides; lower ones interruptedly pinnate; leaflets oblong, obtuse, deeply toothed with blunt teeth, and smaller leaflets intermixed; middle leaves pinnate; leaflets alternate, lanceolate, bluntish, generally entire; upper leaves entire, oblong-ovate, more or less cut or toothed. Flowers panicled; racemes secund, several-flowered. Bractes 2 at the base of the pedicles, oblong, obtuse, equal in size, or sometimes one larger than the other. Pedicles slender, nodding, thickly clothed with villous glandular hairs, as is the calyx. Calyx 5-parted nearly to the base, segments unequal, spatulate, obtuse, fringed, the lower one much the longest. Corolla irregular; upper lip 5-cleft, side laciniæ forked, the lower ones pale rose colour, middle ones lighter, with a purple spot on each 
of the upper segments; upper one oblong, entire, yellow at the base, with a purple spot on each side, and numerous smaller ones between them and the base; lower lip 3-parted, rose-coloured, outer laciniæ falcate, lapping over each other at the points, which are spatulately rounded; middle one obcordate, concave, connivent, enclosing the stamens, which are elastic, and spring upwards as soon as touched. Stamens 4, inserted in the mouth, 2 barren and 2 fertile, with the rudiment of a fifth inserted in the lower lip; barren filaments densely bearded, and terminated by barren anthers; fertile ones longer, hairy at the base, and smooth upwards; anthers inserted a little above their base, 2-celled, discharging their ash-coloured pollen by the spring of the filament. Germen sinooth. Style smooth, longer than the stamens. Stigma a simple point.

This beautiful annual was introduced from South America, at the same time as S. pinnata, fol. 63. We, with Dr. Hooker, believe it to be a distinct species, as it is quite different in habit, and the differences remain true from seed. The present is the most beautiful of the two, and it requires precisely the same treatment as the other; we have seen some plants cultivated in peat soil, and others in the common ground, the latter succeeded best; several of those in the peat died off while in full bloom.

Our drawing was taken at the Nursery of Messrs. Whitley, Brames, and Milne, at Fulham, where plants of both species were grown together in the borders, and the differences were seen to advantage.

1. Calyx, showing the unequal segments. 2. Upper lip of the Corolla, with the 2 barren Stamens attached to it at the base. 3. Lower lip of ditto, show ing the situation of the 2 fertile Stamens. 4. Side view of the lower lip, to show the rudiment of a fifth. Stamen. 5. The 2 barren Stamens detached, showing their termination with imperfect Anthers. 6. Style. 


\section{1}
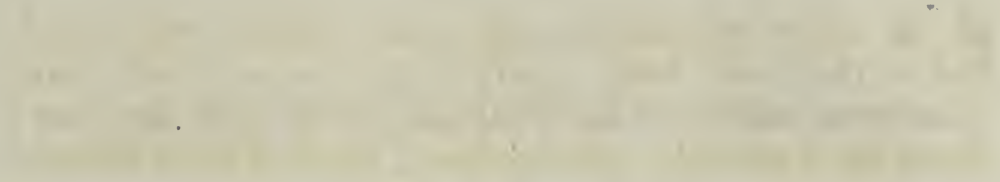

-

$+1$

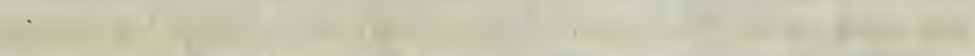

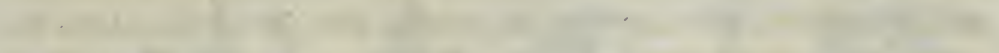

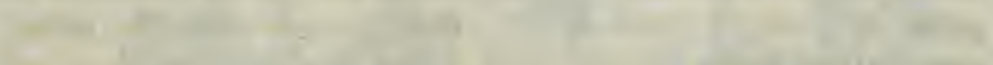

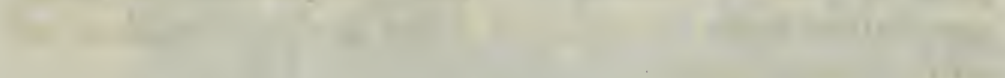

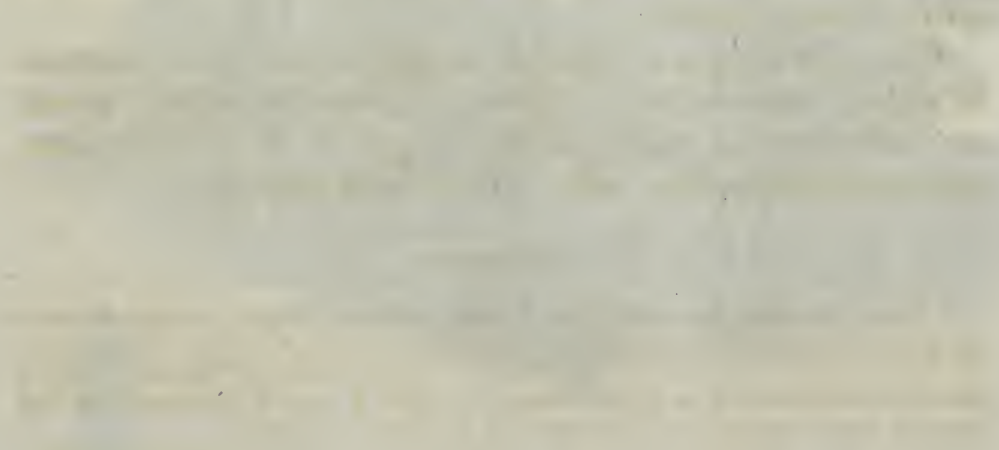




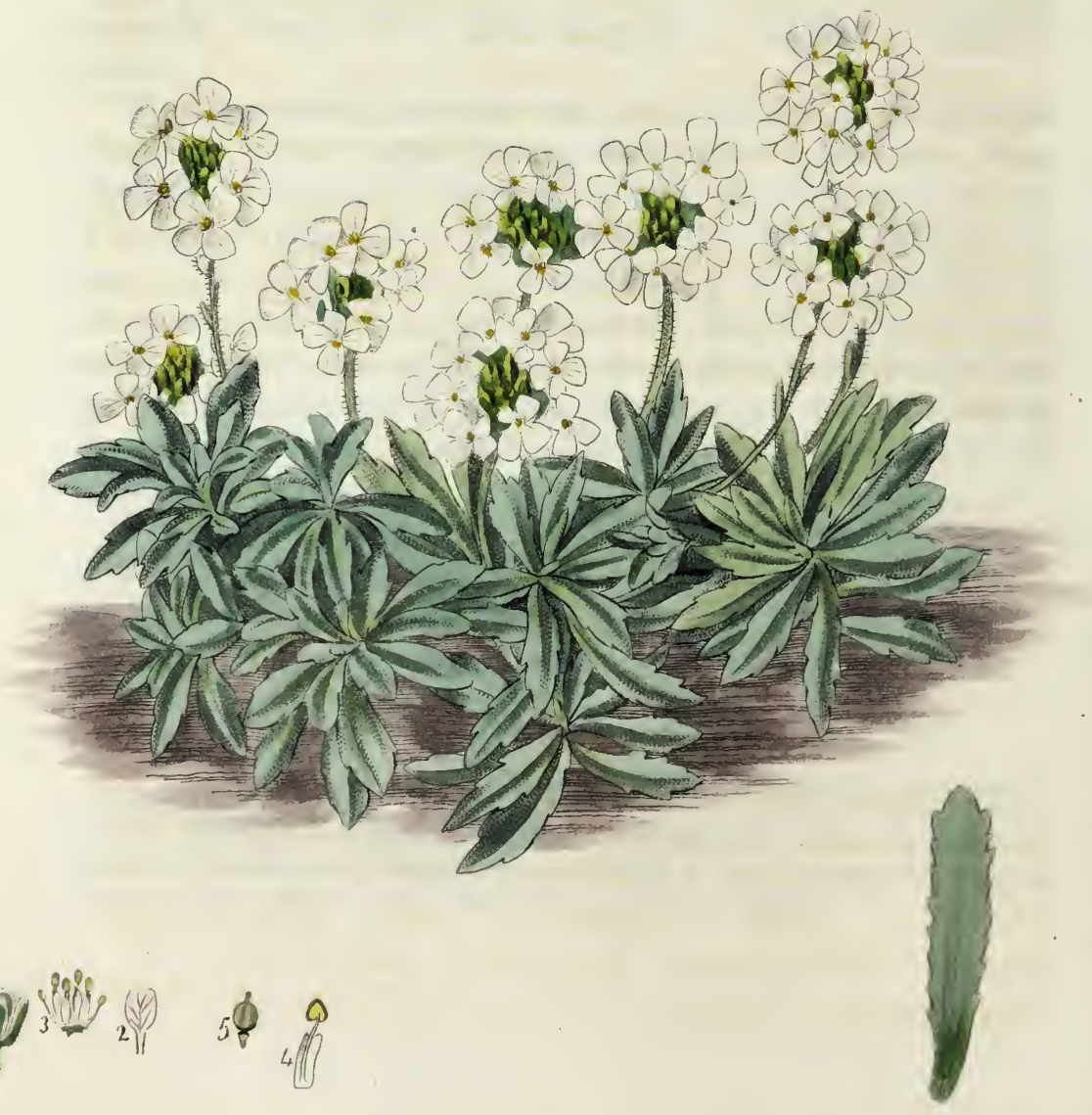




\title{
SCHIVERECKIA podolica.
}

\author{
Canescent Schivereckia.
}

Natural Order. Cructarerk. DC. Syst. nat. 2. p. 139.

Subordo I. PLEURORHIZEF. Supra fol. 46.

Tribus II. ALYSSINEE SEU PLEURORHIZEA LATISEPTE.

Silicula longitudinaliter dehiscens, septo lato ovali membranaceo, valvis planis aut concavis. Semina compressa, sæpè marginata. Cotyledones planæ, accumbentes, septo parallelæ. DC. $p .147$.

SCHIVERECKIA. Calyx basi æqualis, laxiusculus. Petala obovato-oblonga. Stamina 2 breviora filiformia, 4 membranacea dente aucta. Silicula ovata, valvis convexis medio longitudinaliter depressis solidiusculis obtusis; stylo brevi; stigmate capitellato. Semina in quoque loculo 8-10, biseriata, subcompressa, immarginata. Cotyledones ellipticæ, accumbentes.

Herba perennis. Alyssum aut Drabam habitu referens, pube stellatâ velutino-canescens. Folia radicalia rosulata ovalioblonga dentata: caulina pauca sessilia amplexicaulia. Racemi terminales. Pedicelli filiformes, ebracteati. Flores albi. Ovaria et Siliculæ pube brevi molli cano-velutina. DC. loc. cit. p. 300.

Schivereckia podolica. DC. loc. cit. Prodr. 1. p.160. Deless. ic. sel. 2. t. 36.' Link enum. 2. p. 157. Alyssum podolicum. Bess. cat. h. Crem. 1816. p. 8.

Perennial, tufted. Stems short, suffruticose at the base. Leaves rosulate, tufted, oval or oblong, obtuse, more or less toothed, stellately canescent; stem ones few, short, sessile, clasping the stalk. Flower-stalks densely clothed with a short white pubescence. $R \boldsymbol{R}$ cemes terminal, at first in a dense corymbus, afterwards 
lengthening out. Pedicles filiform, without bractes, 2 or 3 times longer than the calyx. Calyx of 4 short sepals, equal at the base, lax, concave, blunt, stellately canescent. Petals 4, white, obovately oblong, entire, about twice the length of the calyx. Stamens 6, 2 rather shorter than the others, filiform ; 4 longer ones, membranaceous, toothed. Silicle ovate, densely clothed with short soft white down. Style short, pubescent. Stigma capitate.

This pretty little Alpine plant has been lately introduced to our collections, and we believe was first raised from seed by Mr. William Anderson, at the Apothecaries' Company's Garden, at Chelsea, about 3 years back, and from a plant received from him our drawing and description were taken. It is well adapted for the ornamenting of rock-work, or for planting on a sloping ground in a dryish situation, as it is more liable to be injured by too much moisture, than it is from cold ; for being a native of Poland and Siberia, it is quite hardy. It may also be cultivated with advantage in small pots with other dwarf growing Alpine plants; but care must be taken to keep it from the slugs and snails, which are very fond of it. It succeeds best in a light sandy soil, and if grown in pots, may be planted in an equal mixture of soft loam, peat, and sand. It strikes readily from cuttings planted under hand-glasses, and may also be raised from seeds, which ripen plentifully; those may be sown as soon as ripe, the plants will then come up directly, and will flower the next Summer; if sown in Spring, the plants will seldom flower till the following season.

1. Calyx. 2. One of the petals. 3. The 6 Stamens, showing the 2 short filiform filaments, and the 4 longer membranaceous toothed ones. 4. Stamen detached. 5. Silicle, or pod, terminated by its short Style, and small capitate Stigma. 



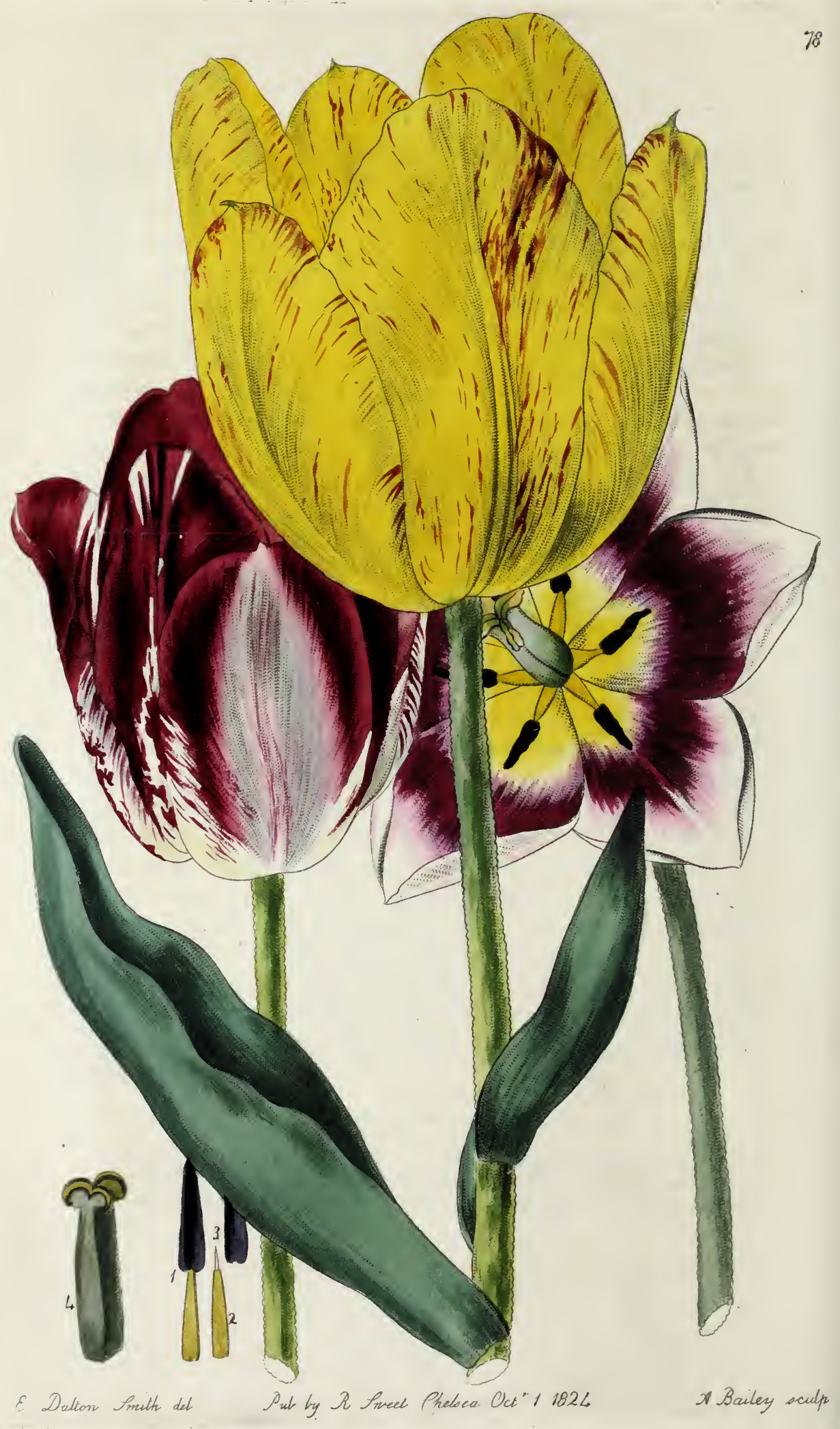




\title{
TULIPA pubescens.
}

\author{
Pubescent-stalked Tulip.
}

Natural Order. TuliPace.t. Kunth. Synops. 1. p. 292.

TULIPA. Perianthium 6-phyllum, petaloideum, campanulatum; foliola recta non nectarifera. Stamina 6 , basi foliolorum inserta. Anthera posticæ. Stylus 0 ; stigma sessile. Capsula oblonga, obtuse trigona; semina plana.

Folia vaginantia radicalia; scapus 1-florus erectus, pene aphyllus. Juss. gen. 48.

T. pubescens, scapo pubescente, perianthii foliolis tribus exterioribus acutis interioribus obtusis mucronatis, foliis oblongolanceolatis venosis utrinque pubescentibus.

Tulipa pubescens. Willd. enum. supp. 17.

'Tulipa suaveolens $\beta$ latifolia. Botan. magaz. 2388.

Root bulbous, about the size of a walnut, clothed with a smooth brown scale, and terminated at the base with a dense fascicle of small white fibres. Leaves clasping the stem, a little waved, strongly veined, and densely clothed on both sides with a short close mealy pubescence; lower ones oblong, acute; upper ones lanceolate, taper-pointed. Scape densely clothed with a white mealy pubescence, shorter than the leaves when the flowers first expand, but afterwards lengthening beyond them. Perianthium of 6 leaflets, various in colour, 3 onter ones acute, inner ones obtuse, all mucronate. Stamens 6 , inserted in the base of the leaflets; filaments flat, channelled on the inner side, and convex on the outer, slightly pubescent; anthers joined to the filaments at their back, about the same length, linear, acute. Germen obtusely-trigonal, about 
the length of the stamens. Stigma 3-lobed, sessile, double crested, waved, deeply channelled, and fringed round the edges.

We agree with Willdenow in considering the broad leaved pubescent Tulip as a distinct species, both from T. suaveolens and T. Gesneriana; perhaps it is hybrid between the two, as it is as near as possible intermediate. Like the latter species it varies in colour, scarcely any two being exactly alike; and they are distinguished by different names by the Florists, as the Clarimond, Bruids van Haarlem, Red and Yellow Pottebakker, \& c. It agrees with T. suaveolens in its pubescent stem, but its habit is more like T. Gesneriana; the time of flowering is between the two. At any rate they are very ornamental plants for the Flower-garden, and require the same treatment as the more common species, succeeding well in a light rich soil; they are also very proper for forcing in pots, as they come in flower early, so that they force well; as soon as they have done flowering, and the leaves are beginning to fade, the bulbs should be taken out of the ground, and kept dry till Spring.

1. One of the Stamens, with the filament joined to the back of the anther. 2. Filament separated from the anther. 3. Anther divested of the filament. 4. Germen terminated by the 3-lobed Stigma. 



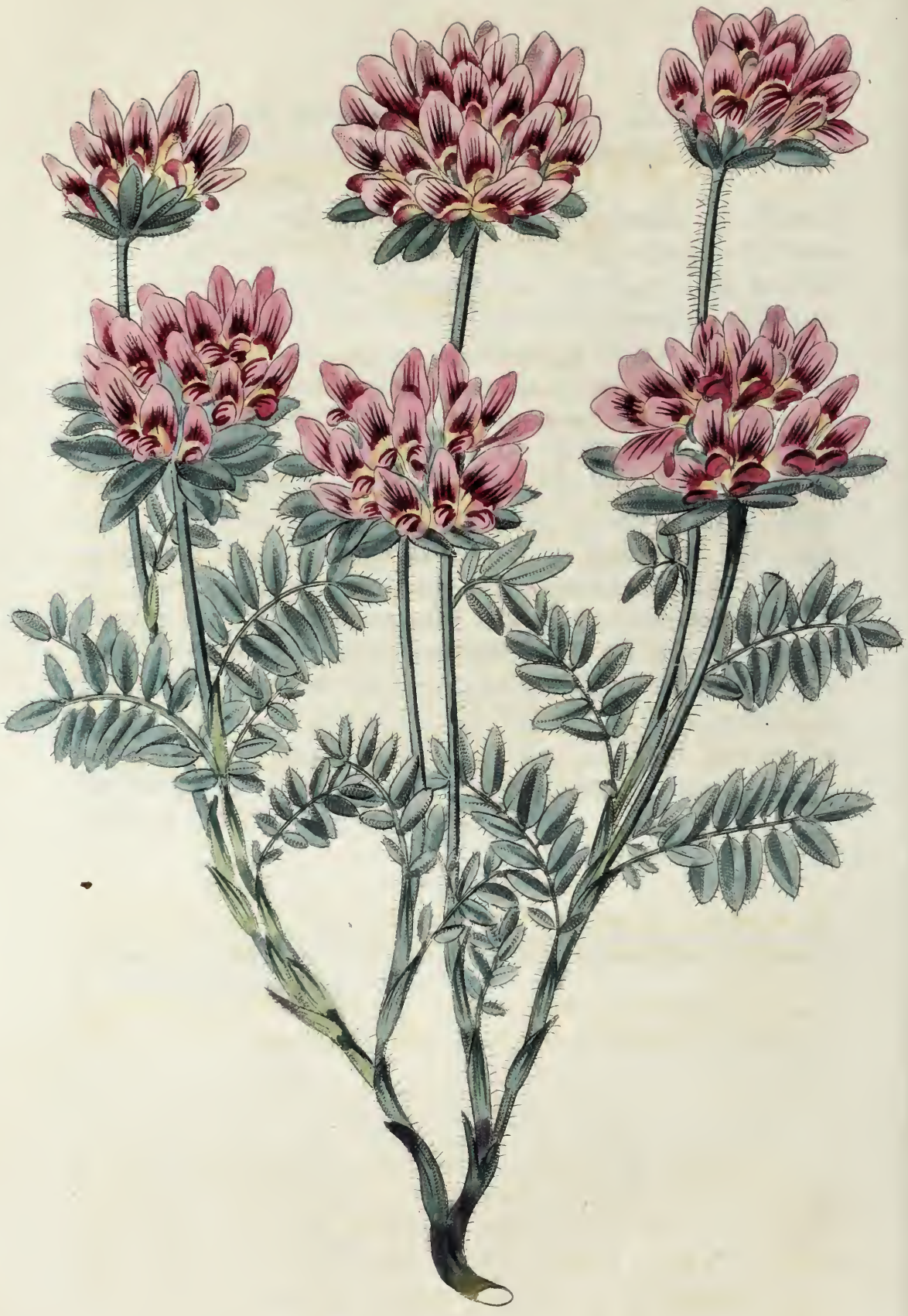

(4) 


\title{
ANTHYLLIS montana.
}

\author{
Mountain Kidney-vetch.
}

Natural Order. Leguminose. Juss. gen. 345.

Div. V. (PAPILIONACEE.) Corolla irregularis papilionacea. Stamina decem diadelpha. Legumen uniloculare bivalve.

ANTHYLLIS. Calyx ventricosus 5-dentatus inæqualis persistens. Corolla vexillum alis et carinâ longius. Stamina basi monadelpha. Legumen parvum 1-3-spermum, calyce tectum. Caulis in Vulnerariâ T. herbaceus, in cateris frutescens, ramis Erinaceæ numerosis suboppositis apice pungentibus; hujus folia simplicia, ceterarum ternata aut sapiùs impari-pinnata; stipula in plurimis ima petiola adnate, in paucis subnulla; pedunculi glomeratim multiflori, axillares aut sapius terminales. Hùc refert D. Lamarck Ebenum L. ab Ebeno ligno diversissimum, cui calyx 5-aristatus aristis plumosis corollâ paulò longioribus, ala minima, semen 1 villosum, catera Anthyllidibus frutescentibus similia. Juss. gen. 355.

A. montana, herbacea, foliis pinnatis æqualibus, capitulo terminali secundo, floribus obliquatis. Willden. sp. pl. 3. p. 1014.

Anthyllis montana. Jacq. austr. 3. p.17. t. 334. Pers. syn.2. p. 292. Lam. ill. t.615. f. 5. Hort. Kew.ed. 2. v. 4. p. 282.

Perennial. Stems numerous, prostrate, much branched; branches short, ascending, villous. Leaves pinnate, canescent, thickly clothed with soft white villous hairs; leaflets 16 to 30 , opposite, lanceolate, acute, broad at the base, terminal one broadest, obovate. Pelioles channelled on the upper side, and convex on the lower. Stipules connected to the base, and forming a part of the petioles. Peduncles cylindrical, 
villous, as are the bractes and calyx. Flowers in a close secund head, pale red, veined with purple. Involucre of numerous lanceolate or oblong bluntish bractes. Pedicles very short and slender, hairy. Caly $x$ slightly ventricose, 5-toothed, persistent ; teeth unequal, subulate, bearded. Corolla papilionaceous; vexillum large, obovate, much longer than the wings and keel, eared just above the unguis. Stamens 10 , all connected at the base; filaments smooth. Pollen pale yellow, granular. Germen and Style smooth. Stigma capitate.

Our drawing of this beautiful plant was taken from a fine specimen growing in the open border, at the garden belonging to the Apothecaries' Company, at Chelsea, in June last. It is quite hardy, and a proper plant for the front of flower-borders, as it seldom exceeds 6 inches in height; but its branches spread round to a considerable distance. It is also a pretty plant for ornamenting rock-work, thriviug well in any light sandy soil.

A native of different parts of Europe, in the more southern districts, and chiefly found in mountainous situations. It may be cultivated with advantage in a smallish size pot, but requires a plentiful supply of water in warm weather. The best method of increase is by dividing at the root, or by seeds, which sometimes ripen plentifully. Cuttings may also be rooted under common hand-glasses; but they must be planted thinly, or they will be liable to damp.

1. Calyx. 2. Vexillum. 3. 3. The 2 alæ, or wings. 4. Carina, or Keel. 5. Stamens spread open, to show that the filaments are united in a tube at the base, and the points distinct. 6. Germen, Style, and Stigma. 



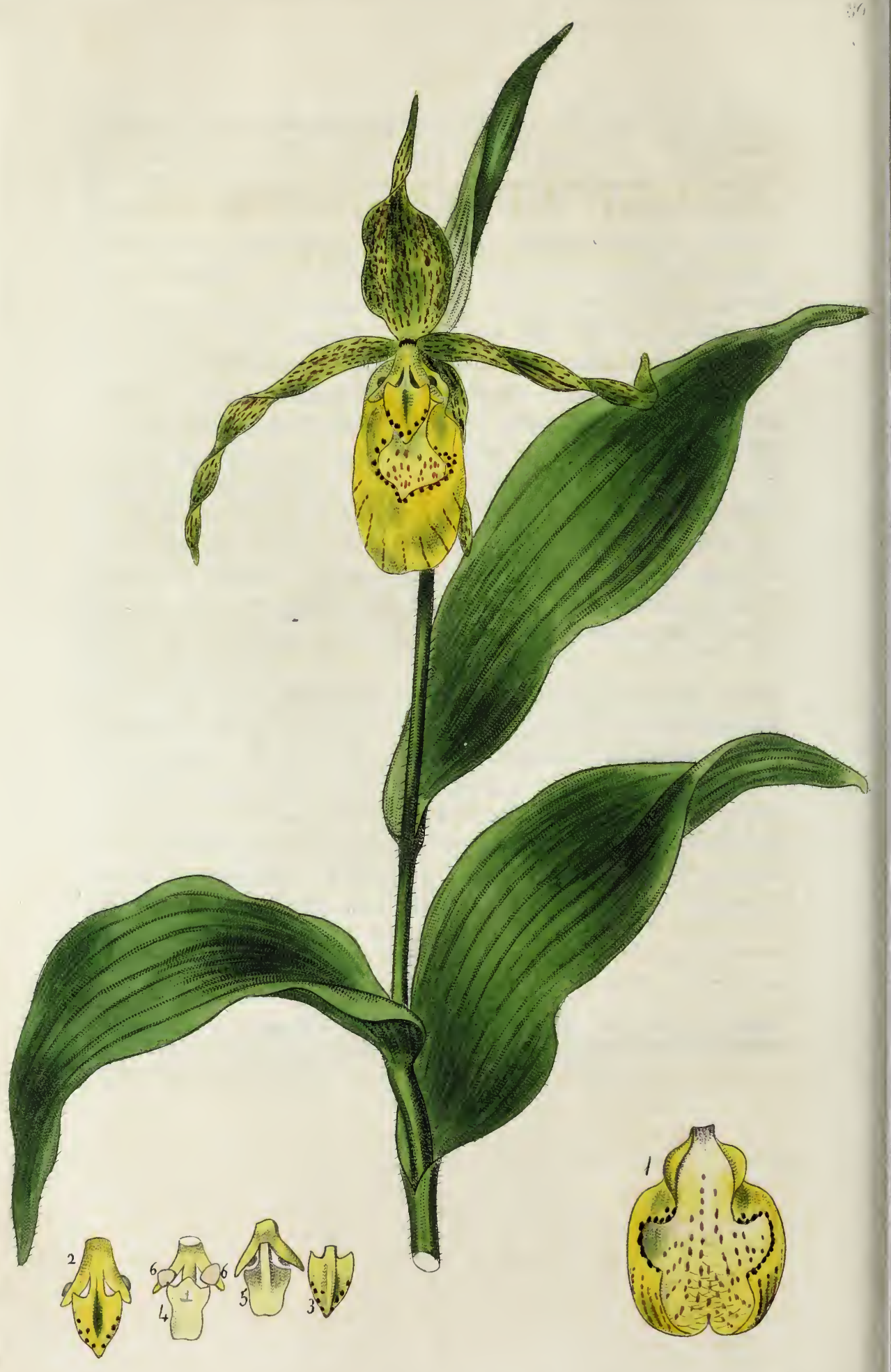




\title{
80
}

\section{CYPRIPEDIUM parviflorum.}

\author{
Small-flowered Ladies' Slipper.
}

Natural Order. ORCHIDEe. Brown prodr. 309.

CYPRIPEDIUM. Supra fol. 71.

C. parviflorum, caule folioso, lobo styli triangulari acuto, perianthii foliolis exterioribus ovato-lanceolatis acuminatis : interioribus linearibus contortis basi intus dense barbatis, labello subsulcato foliolis breviore compresso.

Cypripedium parviflorum. Pers.syn.2. p. 525. Botan.magaz. 911. Pursh. fl. amer. 2. p. 594. Hort. Kew. ed. 2. v. 5. p. 221. Salisb. in Linn. trans. 1. p.77. t.2. f. 2. Willden. sp.pl. 4. p. 143.

Stem flexuose, striated, pubescent. Leaves 5 or 6 , of a thin texture, alternate, sessile, clasping the stem at the base, spreading, their points a little twisted and recurved, oblongly lanceolate, taper-pointed, longitudinally nerved and plaited, furrowed on the upper side, downy. Flower solitary, nodding. Peduncle scarcely as long as the leaf, densely pubescent. Bracte 1, a little below the germen, leaf-like, lanceolate, taperpointed, twisted, a little longer than the leaflets of the perianthium. Pedicle very short, enclosed in the bracte. Germen angular, not twisted, densely pubescent. Leaflets of the Perianthium of a yellowish green, marked with numerous brown spots and lines: 2 outer ones ovately lanceolate, taper-pointed, the upper one erect, twisted, lower one straight, dependent, shorter than the labellum; inner ones longer, linearattenuated, spreading, slightly deflexed, much twisted, point bluntish, densely bearded inside with long white 
hairs at the base, and a considerable way up, outside pubescent. Labellum yellow, smooth outside and marked with a few purplish stripes, the mouth edged with purple; inside beautifully spotted in circular lines, bearded at the base. Column lobe broadly sagittate, entire, bluntish, smooth on both sides, channelled on the upper side and concave near the point, keeled underneath, the keel channelled, yellow, the edges spotted with brown purple. Style pale yellow; middle lobe triangular, with a hollow round point; side lobes lanceolate, scarcely acute, terminating beyond the anthers. Anthers 2, nearly orbicular, attached to the side lobes of the style. Pollen waxy, yellow.

The present plant is a native of North America, growing, according to Pursh, in shady fertile woods, from New Jersey to Carolina. The specimen from which our drawing was taken, was received by $\mathrm{Mr}$. Colvill, last Autumn, from North America, and was cultivated in a pot; the soil was a light red sandy loam. Our plants flowered from the beginning to about the middle of May, earlier than C. pubescens, which we published in a former number. We have seen plants of this genus thriving very well when planted out in a pit, in a rich sandy soil, and occasionally covered with the lights, in wet weather, at the time that the plants were dormant; we have no doubt but the greater part of the family to which they belong would succeed well, managed in that way, as they generally suffer most from moisture when in a dormant state.

1. Labellum cut open, to show the spots and bearding inside. 2. Front view of the column lobe, with the upper lobes of the style attached to it. 3. Back view of ditto, showing its hollow keel. 4. The lower lobe of the Style. 5. Back view of ditto. 6. 6. The 2 Anthers attached to the side lobes of the Style, the points terminating beyond them. 



\title{
MALVA mauritiana.
}

\author{
Ivy-leaved Mallow.
}

Natural Order. Malvaces. DC. prodr. 1. p. 429.

Div. I. Calyx duplex seu involucro cinctus.

MALVA. Calyx 5-fidus, 3-rarius 1-2-4-bracteatus, persistens. Petala 5, hypogyna, æqualia, patentia. Stamina crebra, monadelpha; tubo stamineo unguibus petalorum adnato. Anthera reniformes, uniloculares. Ovarium superum, polycoccum; coccis 1, rarissime 2-4-spermis vel dissipimento transverso spurio in duos divisis loculos 1-spermos. Styli tot quot cocca. Stigmata capitellata. Capsula polycocca; coccis 1-spermis, rarissime 2-4-spermis vel in duos divisis loculos monospermos dissipimento (spurio) transverso, e dorso cocci orto ibique affixo, reliqua parte libero. Radicula in monospermis infera. Herbæ, suffrutices aut frutices, rarius arbusculæ. Folia alterna, integra aut sapissime angulata, lobata vel digitatopartita. Stipulæ petiolares gemina. Pedunculi axillares, uniflori, solitarii, gemini vel plures, interdum bi-multiflori; in nonnullis flores spicati vel racemosi terminales, aut in axillis conglomerati. Corollæ miniata, purpurea, violacea, carulea, rosea, carnea, alba vel flava. Kunth. Synops. 3. p. 247.

Sect. I. MaLVASTRUM. Carpella 1-locularis 1-sperma. DC. l. c. p. 430 .

§. 5. Fasciculatæ, floribus purpurascentibus aut albis, foliis angulatis cordatis 5-nerviis, pedicellis axillaribus plurimis 1-floris, calyce exteriore 3-phyllo, caule herbaceo. DC. l. c. p. 432.

M. mauritiana, caule erecto, foliis 5-lobatis obtusis, pedicellis petiolisque glabriusculis aut ad latus superius tomentosis. DC. prodr. 1. p. 432.

Malva mauritiana. Cav. diss. 2. p. 77. t. 25. f.2. Willden. sp. pl. 3. p. 787. Pers. syn. 2. p. 251. Hort. Kew. ed. 2. v. 4. p. 216.

Annual. Stem smooth, erect, 3 to 5 feet high, branched at the base. Leaves large, glossy, rugose, 5 -lobed, obtuse, unequally toothed with large blunt teeth, entire at the base, underneath strongly 5-nerved, 
nerves branched, slightly hairy. Petioles flattened and furrowed on the upper side, densely tomentose; nearly smooth and rounded underneath, a little widened at the base, gradually tapering upwards. Stipules ovate or lanceolate, acute, membranaceous. Flowers axillary, numerous, fasciculate. Peduncles slender, slightly hairy, many times shorter than the petiole. Calyx double; outer one or involucre 3-leaved, leaflets oblong, obtuse, many-nerved ; inner one salvershaped, 5-cleft, segments bluntly rounded, pubescent, reticulately veined. Corolla of 5 petals, spreading, obcordate, narrow and bearded at the base, 5 -nerved, of a bright purple, darkest near the base, nerves dark purple. Stamens numerous, connected in a tube, and distinct at the points, tube thickly clothed with short hairs, points smooth, fasciculate, spreading; anthers reniform. Carpella many, connected in a circular capsule, rugged, each 1-seeded. Seeds smooth and shining.

A stately and very handsome hardy annual, requiring only to be sown in the open ground, in the common garden soil, where it will continue to bloom till late in Autumn, and ripen abundance of seeds; the best time for sowing them is the beginning of March, if the weather prove favourable; and as they are of large growth, the plants should be at least 9 inches or a foot apart; they will otherwise crowd each other, and will not be near so fine.

Our drawing was taken at the Nursery of Mr. Colvill, in August last.

1. The onter Calyx of 3 bracte-like Sepals. 2. The inner 5-cleft Calyx, showing part of the Capsule, or seed-vessel. 3. Petal, showing its bearded base. 4. Stamens, showing the hairy tube and spreading points, with their kidney-shaped anthers. 5. Style and Stigmas. 6. Seed-yessel. 7. Seed. 



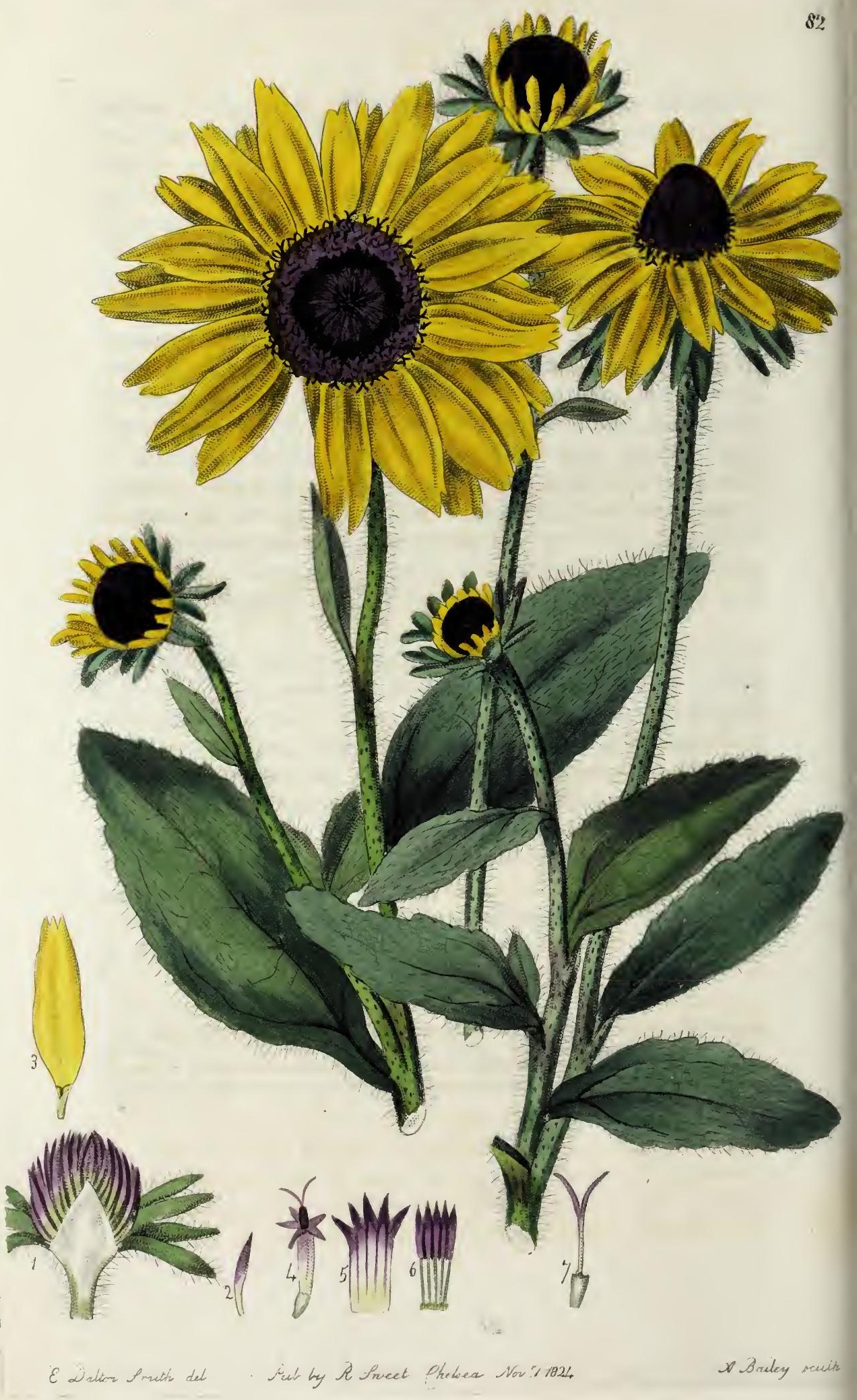




\title{
82
}

\section{RUDBECKIA hirta.}

\author{
Great Hairy Rudbeckia.
}

Natural Order. Composite. Adanson fam. 2. 103.

RUDBECKIA. Supra fol. 4.

R. hirta, hirsutissima, caulibus subramosis; ramis unifloris, pedunculo nudo, foliis ovato-spathulatis triplinervibus serratis hirtis, involucrum foliaceum radium subæquante, disco conico, paleis lanceolatis.

Rudbeckia hirta. Willden. sp. pl. 3. p. 2248. Pers. syn. 2. p. 477. Pursh fl. amer. sept. 2. p. 574. Hort. Kew. ed.2. v. 5. p. 131.

Stems erect, branching from the base, thickly clothed with long spreading white hairs, as are the leaves, peduncles, and involucrum. Branches erect, purple at the base, generally 1 -flowered. Leaves ovatelyspatulate, attenuated at the base, sessile, slightly serrate, bluntish, triplinerved, the nerves branching: Peduncles long, erect, angular, and furrowed with numerous channels, naked, or sometimes bearing a leaf, hispidly hairy. Involucre many-leaved; leaflets spreading, or reflexed, unequal in length, lanceolate, bluntish, hispidly hairy, some of them nearly the length of the rays. Receptacle conical, paleaceous. Chaff lanceolate, acute, tipped with purple, scarcely as long as the florets. Rays numerous, barren, ligulate, the points 2 or 3-toothed, strongly nerved underneath, of a deep yellow colour, at the base is the rudiments of 2 hair-like stigmas. Florets of the disk numerous, dark brown, tubular, 5-toothed. Stamens 5, filaments 
smooth, distinct; anthers connected into a tube, exserted; pollen bright yellow. Style smooth, about the length of the stamens. Stigmas 2, purple, spreading.

The present handsome plant is often confounded with R. fulgida in our collections, but is a very distinct species, and not so easily kept in good health as that, being very apt to die off in Winter, owing, we apprehend, to the variableness of our climate, as it thrives exceedingly well in Summer, and produces abundance of flowers, though it seldom ripens its seeds; we have succeeded very well in raising it from cuttings, by taking off the young shoots and planting them under a common hand-glass, where they rooted in a very short time, and made strong plants the same season. Pursh marks it as a biennial, and mentions it as growing on the mountains, from Virginia to Florida, flowering from July to September. We have no doubt of its being strictly perennial, but very liable to rot off in Winter if grown in too moist a situation; we therefore recommend its being planted in a dry border of rich light earth; and it is also well to have some plants of it in pots, which can be protected in frames in Winter, if the weather be very severe or very wet, they can then be turned into the borders in Spring. It seldom exceeds a foot in height, and is, therefore, an ornamental plant for the front borders of the flower garden.

Drawn at the Nursery of Mr. Colvill, in August last.

1. Capitulum cut through the middle, to show the conical chaffy receptacle. 2. Scale of the chaff. 3. One of the-Rays. 4. Floret of the disk. 5. The same spread open, to show the nerves. 6. Stamens, showing the distinct fila. ments and united anthers. 7. Seed, terminated by the Style and 2 spreading Stigmas. 



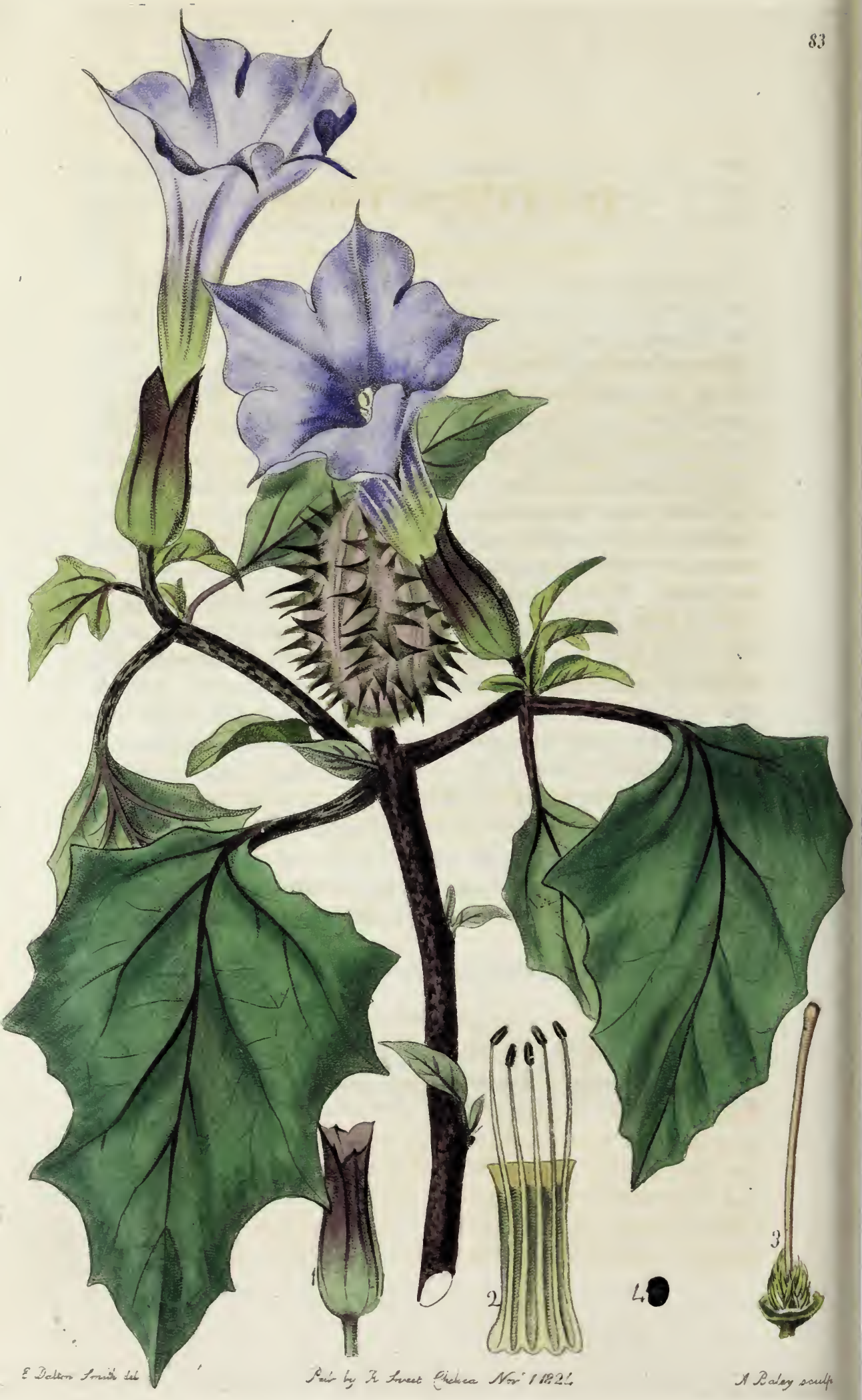




\title{
83
}

\section{DATURA Tatula.}

\author{
Pale Blue Thorn-Apple.
}

Natural Order. Solane E. Brown prodr. 443.

Sect. I. Corolla plicata. Pericarpium capsulare.

DATURA. Calyx tubulosus, basi ventricosus, caducus; basi orbiculari, peltata, persistente; limbo quinquefido, sæpe irregulari. Corolla infundibuliformis ; limbo plicato, angulato, quinque-aut decemdentato. Stamina 5, subinclusa. Anthera longitudinaliter dehiscentes. Stylus longitudine staminum. Stigma bilobum. Capsula semiquadrilocularis, quadrivalvis, sæpius muricato-spinosa; placentæ discretæ. Semina crebra reniformia. Herbæ virosa, rarius arbuscula aut frutices. Folia sapius sinuato-angulata. Flores alares, solitarii, albi, violacei aut coccinei. Kunth. synops. 2. p. 148.

(1) Corolla limbo quinquedentato; dentibus acuminatoelongatis; staminibus inclusis.

D. Tatula, caule herbaceo maculato, foliis ovatis grosse et argute sinuato-dentatis glabris ; dentibus corollæ acuminatocapillaceis, capsulis muricato-spinosis erectis. Kunth. synops. 2. p. 150.

Datura Tatula. Willden. sp. pl. 1. p. 1008. Pers. syn. 1. p. 216. Hort. Kew. ed. 2. v. 1. p. 387. Meerb. ic. 2. t. 13.

Annual, smooth. Stem erect, from a foot to 18 inches in height, purple, spotted with small light spots, branching; branches spreading, purple, also spotted. Leaves ovate, acute, lower ones cordate, sinuate, or deeply and sharply toothed; upper ones oblique at the base, nerves purple. Petioles purple, flattened and furrowed on the upper side, and convex on the lower, shorter than the leaves. Peduncles short: Calyx tubular, ventricose at the base; limb 5-toothed, teeth 
unequal. Corolla funnel-form, limb plaited, 5-toothed, of a pale blue; teeth long, taper-pointed. Stamens 5, inserted in the tube, and included within the mouth; filaments slender, joined to the base of the anthers. Style smooth, about the length of the stamens. Stigma slightly 2-lobed. Capsule erect, spiny, or muricate, the spines unequal in length, pungent. Seeds numerous, kidney-shaped, black and rugged.

The plant from which our drawing was made, was raised from seed received by A. B. Lambert, Esq. from the mountains of the Caracas, where it is mentioned, by the noted travellers, Humboldt and Bonpland, as growing abundantly. It is also found in great quantities in many other countries; or, perhaps, more than one species is confused. Our plant agreed exactly with the description of Kunth, but not so well with that by other authors. It is a pretty annual plant, and flowers best in the open air, attaining the height of a foot, or 18 inches. The seeds may be sown in Spring, either under hand-glasses, or on a slight hot-bed; and as soon as the plants are a few inches high, they should be planted into the flower borders where they are to remain; a warm border of rich light earth will suit them best, where they will continue to bloom till late in Autumn, if the weather continue mild, and will ripen plenty of seeds.

1. Calyx. 2. Tube of the Corolla laid open, to show the insertion of the stamens. 3. Germen, Style, and 2-lobed Stigma. 4. Seed. 



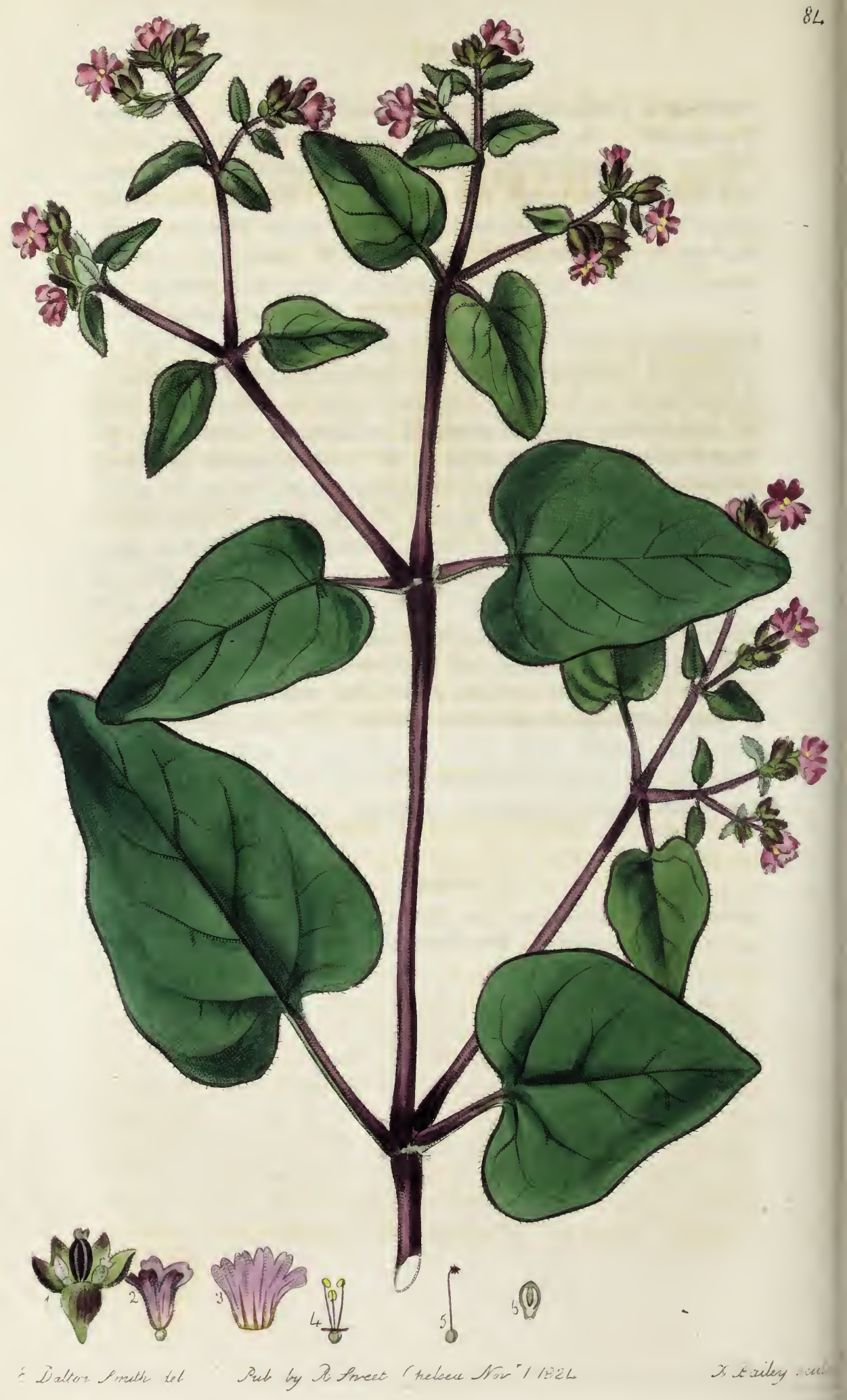




\title{
84
}

\section{OXYBAPHUS Cervantesii.}

\author{
Cervantes' Umbrella-Wort.
}

Natural Order. Nyctaginex. Kunth Synops.2. p. 14.

OXYBAPHUS. Involucrum monophyllum, campanulatum, quinquefidum, 1-, rarius 2-4-florum. Perianthium corollaceum, infundibuliforme; limbo quinquelobo. Stamina 3 aut 4. Akenium basi calycis demum indurata apice clausa tectum, involucro explanato grandefacto circumdatum.

Herbæ superne dichotoma. Folia opposita. Flores in apice ramulorum corymbosi. Kunth Synops. 2. p. 15.

O. Cervantesii, caule geniculato ramoso diffuso, foliis cordatis obtusis pubescentibus margine ciliatis, floribus paniculatis, involucris villoso-viscosissimis trifloris, lobis perianthii emarginatis, staminibus perianthio brevioribus.

Perennial. Roots tuberous. Stem herbaceous, much branched, knotted at the joints, spreading in all directions; branches of a shining purple, bearded at the joints, and a villous line running from one joint to the next, alternate with the leaves. Leaves opposite, longpetioled, cordate, obtuse, entire, slightly pubescent, the margins ciliated with short hairs. Petioles slender, flattened on the upper side, and convex on the lower, pubescent. Flowers panicled, the upper part of the stem, peduncles and involucres villosely viscous, sticking to every thing that touches them. Peduncles slender, erect when in flower, afterwards drooping. Involucre of one leaf, peltate, campanulate, 5-cleft, 3-flowered; segments unequal, imbricate, ovate, acute, concave, keeled. Perianthium funnel-form, plaited, 
5-lobed, of a bright pink colour, lobes deeply emarginate, plicately spreading. Stamens 3 , inserted in the base of the tube, shorter than the perianthium; filaments smooth, purple, attached to the back of the anthers, which are 2-celled, and burst before the flower expands; pollen bright yellow, composed of little round grains. Style smooth, purple. Stigma capitate, fimbriate. Seed angular, rugose.

Our drawing of this plant was taken at the Nursery of Mr. Colvill, where it was raised from seed received from Germany, under the name that we have adopted. It is a native of South America, and the seeds should be sown on a hot-bed in Spring, and from thence be planted either in the open ground, or in pots, in the same manner as Mirabilis, or Marvel of Peru, to which it is nearly related; and like it, the roots require to be taken up in Autumn, and to be kept in dry earth, out of the reach of frost, till Spring, when they may again be planted in the flower borders; a dry warm border of rich light earth suits them best, where they will grow to the height of 18 inches, and will continue to flower till late in Autumn, and ripen plenty of seeds.

1. Involucre spread open, to show the insertion of the 3 flowers, or seeds, the middle one being a ripe seed. 2. Perianthium. 3. The same spread open, slowing its emarginate segments. 4. The 3 Stamens inserted in the base of the tube. 5. Germen, Style, and fimbriate Stigma. 6. Seed cut open, to show its large albumen and the small radicle in the centre. 



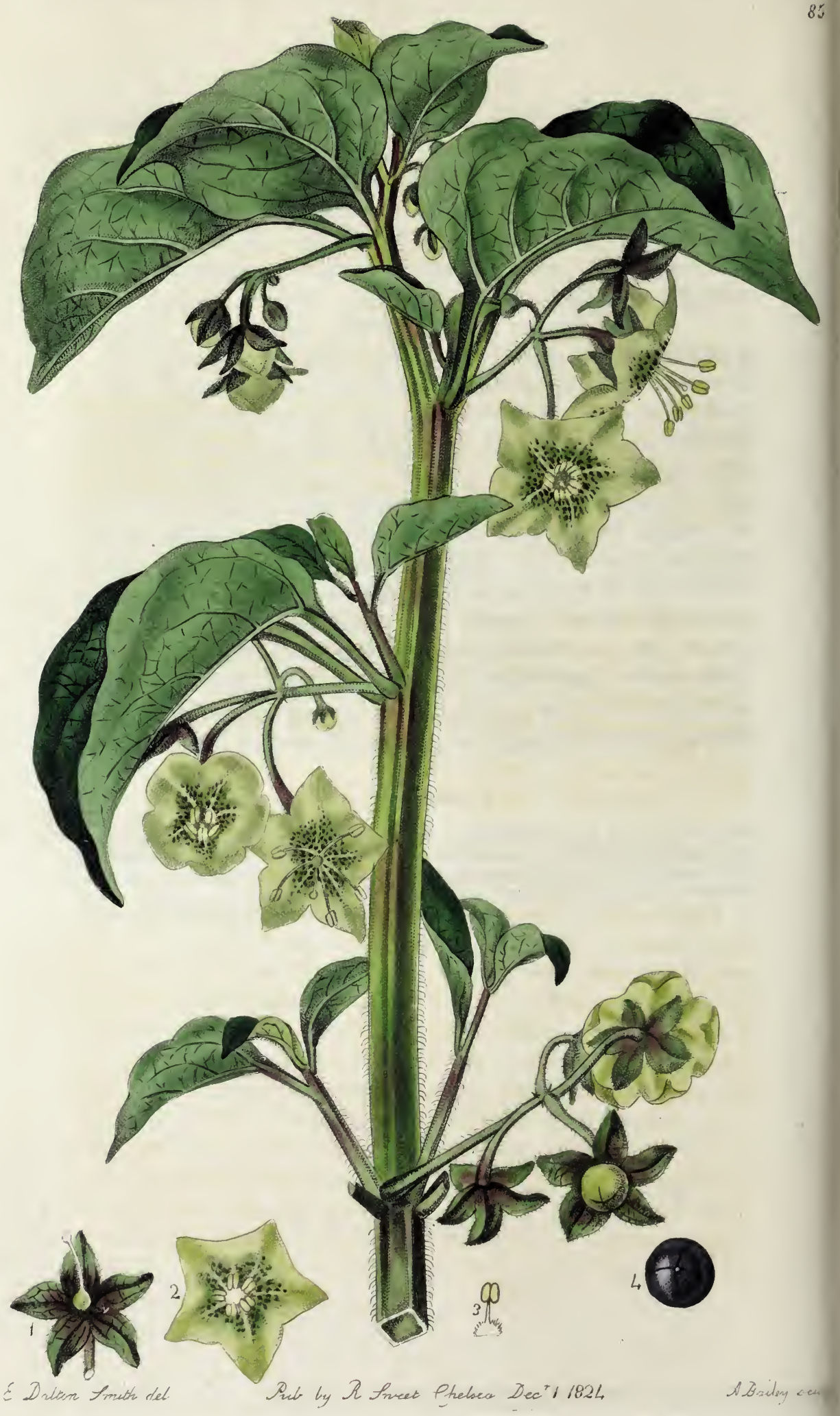




\section{5}

\section{SARACHA umbellata.}

Umbel:flowered Saracha.

Natural Order. Solanea. Juss. gen. p. 124.

Sect. II. Fructus baccatus.

SARACHA. Calyx 5-fidus. Corolla rotato-campanulata, 5-fida. Stamina 5 basi corollæ inserta. Stigma capitatum. Bacca subrotunda, unilocularis. Frutices aut herbæ caulescentes; folia sapiùs geminata; flores extrà-axillares subsolitarii aut conferti.

S. umbellata, caule erecto herbaceo ramosissimo hirto, foliis ovatis rugosis nitidis acutis : floralibus geminis, umbellis axillaribus pedunculatis cernuis, floribus plicatis, filamentis basi barbatis.

Saracha umbellata. DC. hort. mosnp. 1813. 142. Link enum.1. p. 180.

Bellinia umbellata. Rom. et Schult. syst. 4. p. 684.

Atropa umbellata. Jacq. schoobr. t. 493.

Perennial. Root large, tuberous. Stem erect, hollow, much branched; branches spreading, bluntly 4-sided, green and glossy, or slightly tinged with purple, slightly hairy, the hairs pellucid and recurved. Leaves ovate, acute, rugose, glossy, margins rough, generally in pairs. Petioles winged, channelled on the upper side, and rounded on the lower. Umbels 3 to 5-flowered, nodding. Peduncle short, a little above the leaves, generally betwixt the two, angular, sulcate, very hairy. Pedicles nodding, angular, sulcate, very hairy, scarcely as long as the peduncles. Calyx rotate, 5-cleft, hairy, purple at the base ; segments ovately-lanceolate, concave, bluntish, keeled 
at the back, fringed. Corolla rotately-campanulate, plaited, 5-cleft, of a greenish white colour, segments cordately ovate, taper-pointed, spreading. Stamens 5, inserted in the base of the corolla; filaments subulate, gibbous and bearded at the base, and smooth upwards; anthers incumbent. Germen globular, smooth and glossy. Style smooth, about the length of the stamens. Stigma capitate. Berry globular, green when unripe, lighter at the point, where it is crossed by 2 white lines; when ripe, of a glossy jet black.

Our drawing of this curious plant was made at the Nursery of Mr. Colvill, where it was raised, last year, from seed received from the Botanic Garden at Berlin ; some of the plants flowered the same season, but not till late in Autumn; some were planted in the open border, where the roots, this year, grew to a large size, and produced numerous branches, which attained the height of 18 inches to 2 feet, and produced abundance of flowers and fruit. It is a native of Peru, but appears to be quite hardy ; as some of the roots were exposed to all last Winter's frost, in small pots, without receiving the least injury. Its season of flowering is from the beginning of July till the end of September, or later, if the weather prove favourable. It succeeds well in the common garden soil, and is increased by dividing the root, or by seeds, which ripen in abundance.

1. Calyx spread open, showing the Germen, Style, and Stigma. 2. Corolla spread open, showing the insertion of the Stamens at the base. 3. Stamen detached, showing the gibbous bearded base. 4. Ripe Berry. 



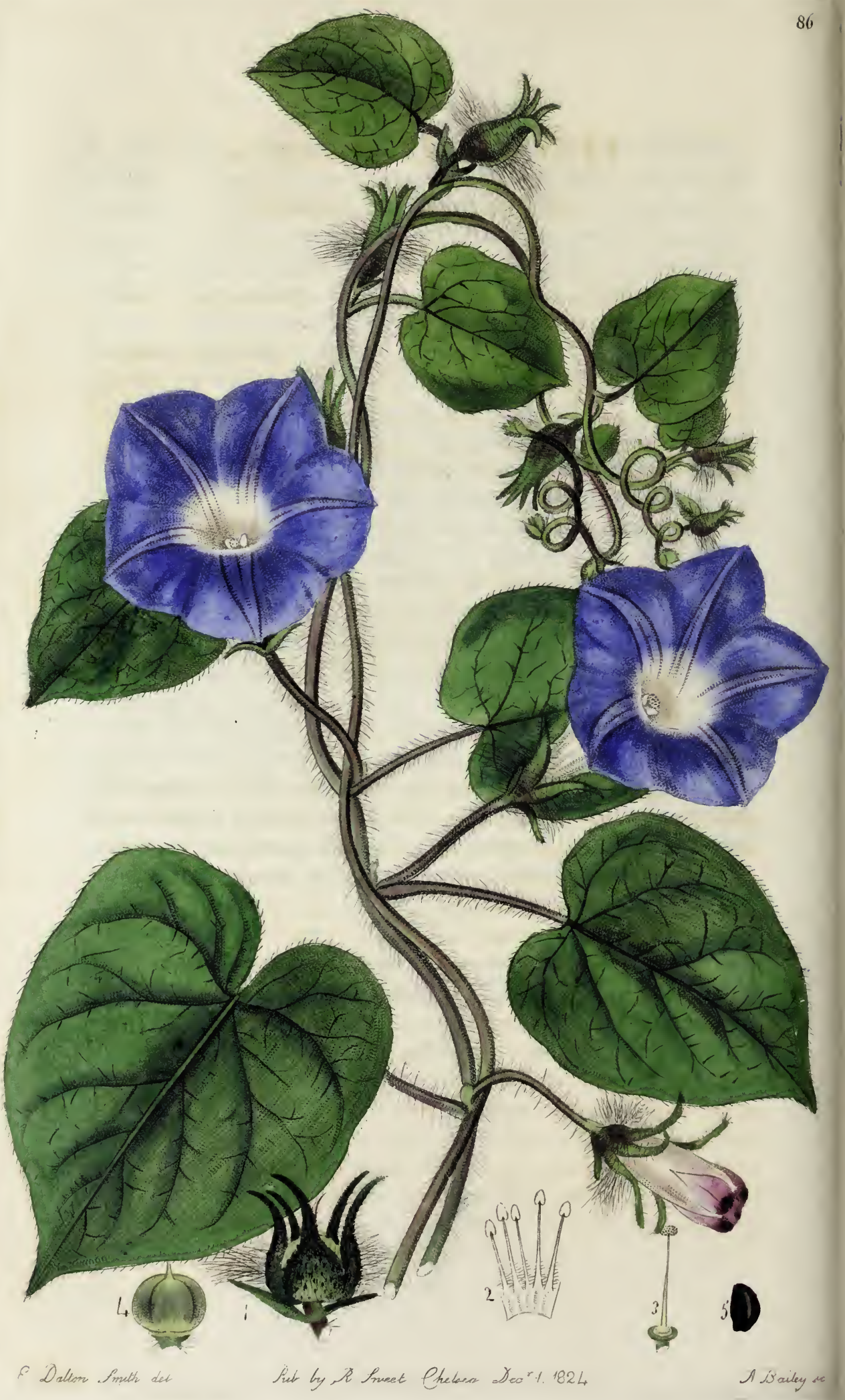




\section{6}

\section{IPOMOEA barbigera.}

\section{Bearded calyxed Ipomoa.}

Natural Order. Convolvulacea. Brown prodr. 481.

Sect. I. Ovarium unicum.

IPOMOEA. Calyx 5-partitus, nudus. Corolla campanulata v. infundibuliformis, 5-plicata. Ovarium 2-3-loculare, loculis dispermis. Stylus indivisus. Stigma capitatum, 2-3-lobum. Capsula 2-3-locularis.-Herbæ volubiles, quandoque erecta. Folia indivisa v. lobata, nunc pinnatifida. Semina in quibusdam comosa. Brown prodr. 484.

I. barbigera, caule volubili retrorsum pubescente, foliis late cordatis acuminatis integris postice rotundatis utrinque hirsutis, pedunculis unifloris petiolo brevioribus juxta calycem bibracteatis, laciniis calycinis acuminatis patentibus apice reflexis basi dense barbatis.

Annual. Stem climbing, more or less branched, thickly clothed with long white reflexed hairs, and shorter ones intermixed. Leaves broadly cordate, taper-pointed, entire, rounded, and nearly closed at the base, hairy on both sides, reticulately veined underneath. Petioles deeply channelled on the upper side, and rounded on the lower, thickly clothed with unequal reflexed hairs. Peduncles 1 -flowered, shorter than the petioles, slender, and smooth at the base, of a dark purple, the upper part green, thickened and hairy. Bractes 2 , at the base of the calyx, linear, taper-pointed, spreading, very hairy. Caly $x$ 5-parted; segments nearly equal in length, keeled at the back, densely bearded at the base, with long spreading white hairs, each seated on a gland; points long and taper, spreading, slightly reflexed; inner segments rather z 2 
narrower than the outer ones. Corolla between campanulate and funnel-form, 5-lobed, slightly crenulate, limb of a bright azure blue; tube pale, or nearly white. Stamens 5, unequal in length, inserted in the tube a little above the base; filaments densely bearded near the base, and smooth at the points; anthers sagittate, joined by their base to the filaments, 2-celled, bursting in front to discharge the pollen, which is composed of small globular white grains. Style quite smooth, about the length of the stamens. Stigma capitate, scarcely lobed, papillose. Capsule smooth, 3-locular, with 2 seeds in each cell. Seed black, roughish, pubescent.

Several plants of this beautiful annual were raised this year, at the Nursery of Mr. Colvill, from seeds received from North America; we believe it to be a new species, as we do not find it any where described; it is nearer related to I. hederacea than to any other with which we are acquainted; but the leaves of that are deeply 3-lobed, while those of our plant are always quite entire, more like I. purpurea, but broader, and more taper-pointed.

Plants that were raised from seeds sown in April, began to flower in June, and continued to bloom till the end of September; some of the seeds were ripe the beginning of July, and, for an experiment, we sowed some of them immediately, as soon as gathered; they were up in 3 days, and began to flower in a fortnight, growing very strong, and continuing to bloom till near the middle of October, and also ripened their seeds. The flowers are in the greatest perfection early in the morning, before the heat of the sun becomes too powerful. It will attain the height of 6 or 8 feet, if trained up a stick, or wire, and thrives best in a warm border of rich light earth.

1. Calyx, enclosing the Capsule, and showing the 2 bractes at the base. 2. Tube of the Corolla spread open, to show the insertion of the 5 Stamens. 3. Style and papillose Stigma. 4. Capsule. 5. Ripe Seed. 


\section{$\checkmark$}

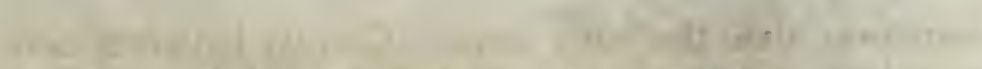

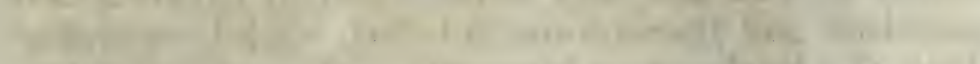

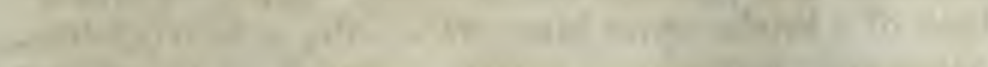

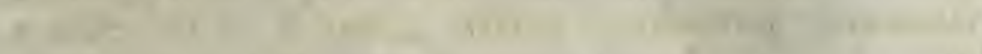

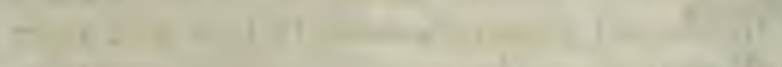

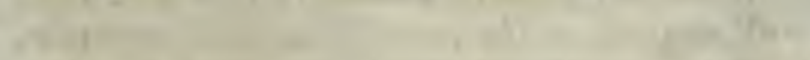

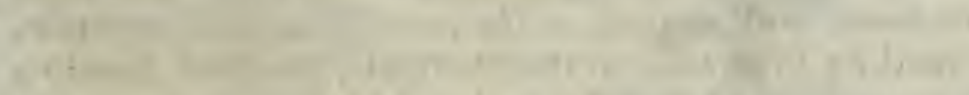

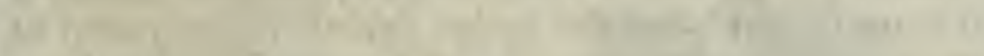

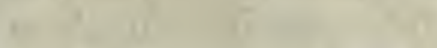

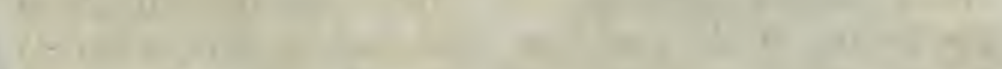

(20)

.

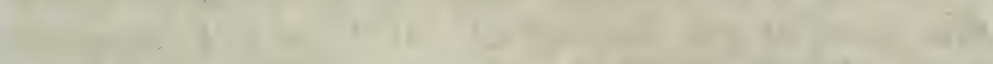

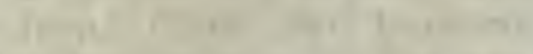

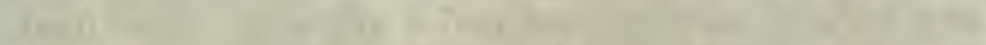

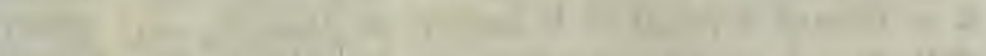
1) 1 |

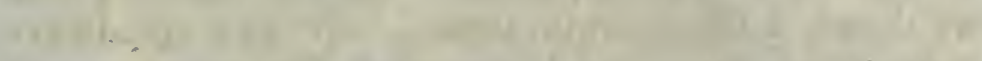

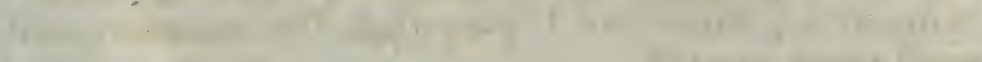

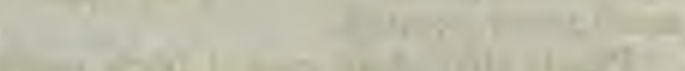

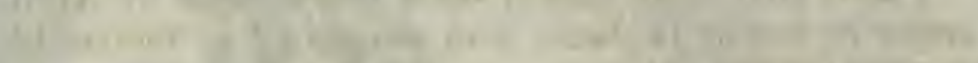

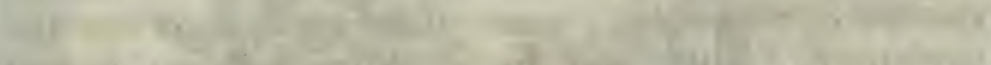

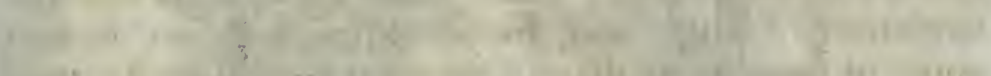

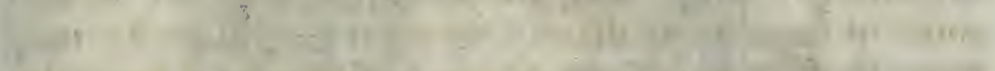

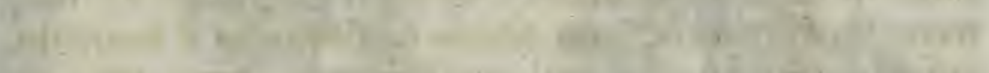

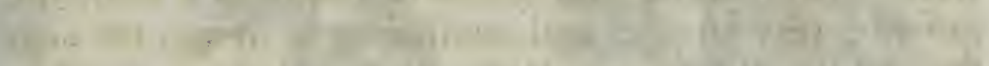

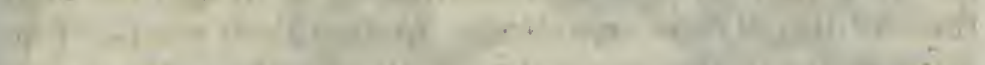

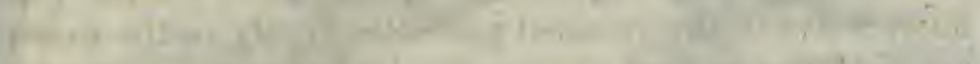

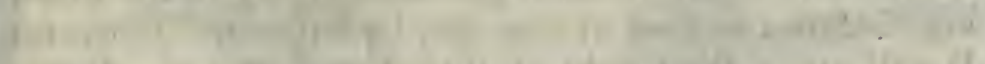

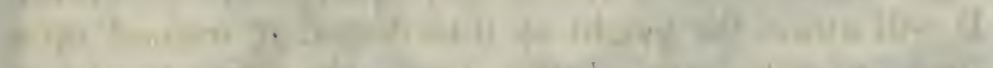

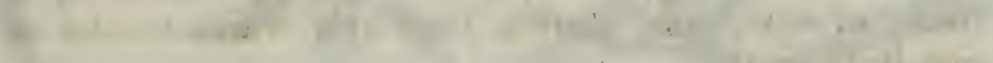

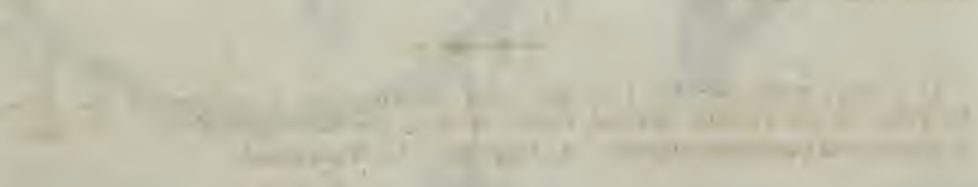




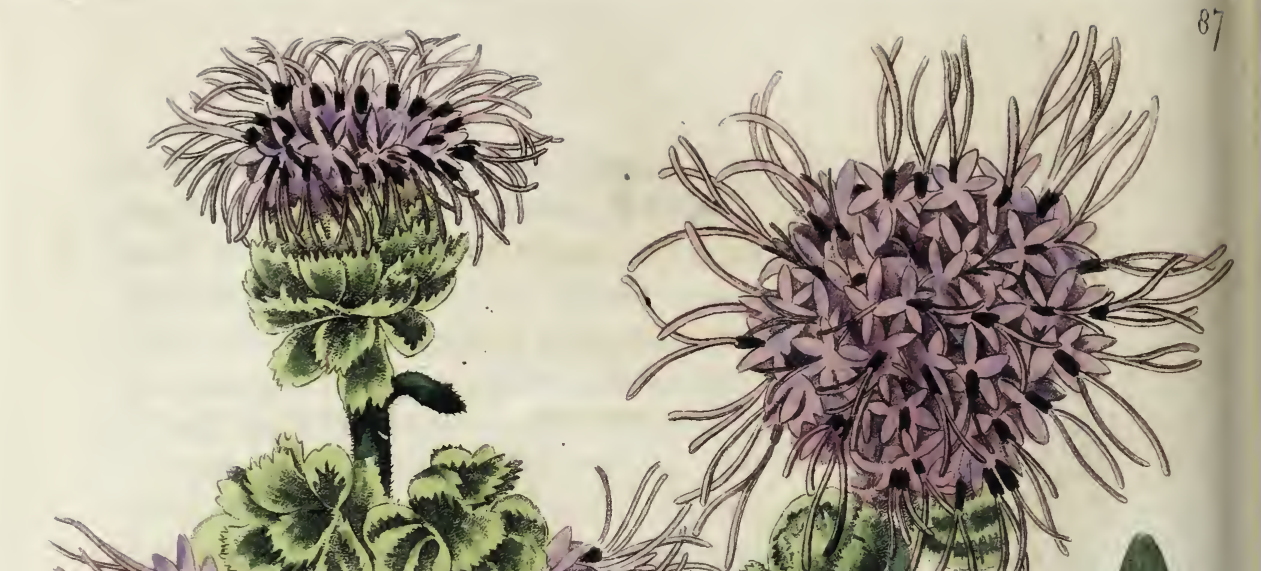

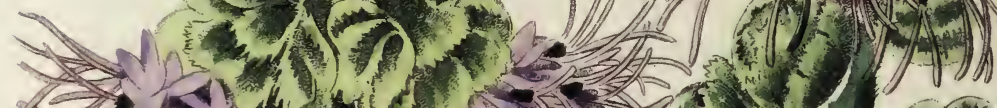

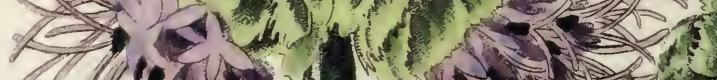

(b)

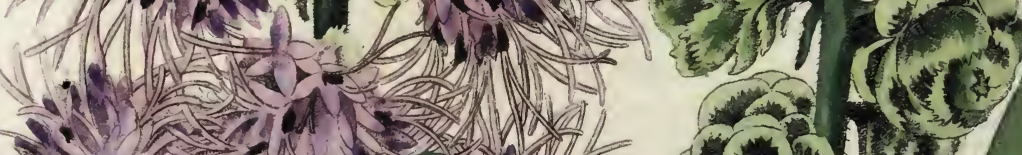

3.t.

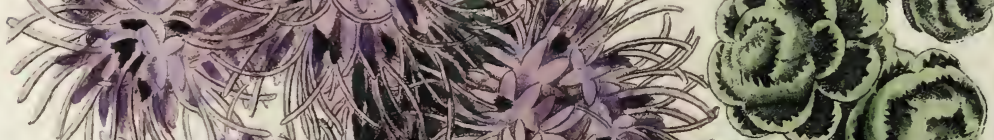

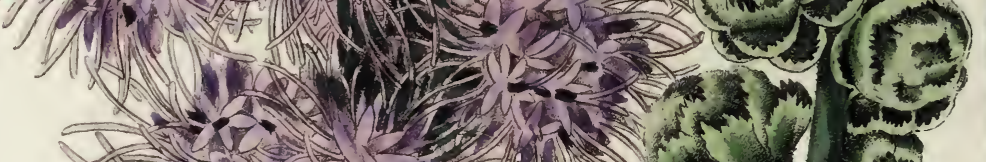

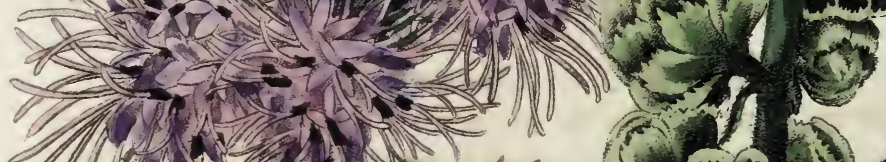

1) M
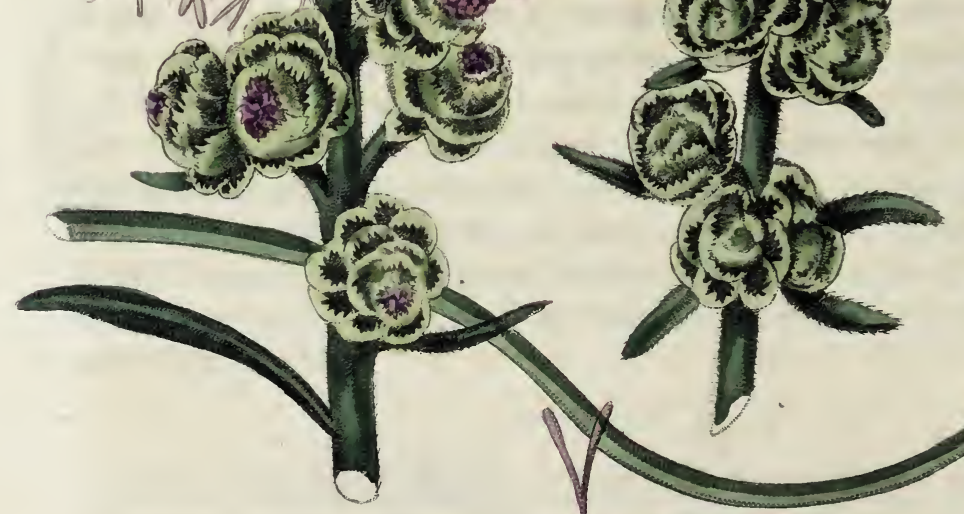


\section{7 \\ LIATRIS sphæroidea.}

Globular-cupped Liatris.

Natural Order. Composite. Adanson fam. 2.103.

Sect. II. CARDUACEE. Div. 5. Vernoniacea.

LIATRIS. Supra fol. 44.

I. sphreroidea, caule simplici pubescente, foliis lævibus subfalcatis obtusiusculis : inferioribus petiolatis lato-lanceolatis; superioribus lanceolato-linearibus, thoribus racemosis solitariis alternis subglobosis, involucri foliolis rotundato-obovatis concavis margine membranaceis ciliatis.

Liatris sphæroidea. Mich. flor. amer. 2. p. 92. Pursh. $f$. amer. sept. 2. p.509. Hort. sub. lond.p. 180.

Root tuberous. Stems simple, erect, pubescent, 2 to 3 feet high. Leaves quite smooth, numerously punctate, of a dark green, more or less falcate, bluntish ; lower ones petiolate, broadly lanceolate; upper ones lanceolately-linear, sessile, slender at the base, more or less twisted. Racemes long, many-flowered. Flowers solitary, alternate, rather crowded, upper ones opening first. Peduncles short and thick, pubescent. Involucre nearly globular; leaflets loose and spreading, roundly obovate, concave, ciliate, margins white and transparent, sometimes tinged with red, scariose; inner ones narrower, spatulate. Receptacle slightly convex, naked, punctate. Florets large, from 25 to 30 , tubular, 5-cleft, of a bright pink, or lilac; tube scarcely as long as the pappus, villous inside; laciniæ lanceolate, acute, spreading, more than half the length of the tube. Stamens 5, inserted in the tube; filaments slender, distinct, glandularly pubescent; anthers connected 
into a tube, but distinct at the points, of a dark purple. Style smooth, about the length of the stamens. Stigmas 2, long and spreading, sometimes twisted, or curled, slightly flattened, scarcely papillose, bluntish, of a bright lilac. Seeds striate, densely hairy, and crowned with a pappus of long white feathered hairs.

This very handsome plant is a native of North America. Pursh mentions it as growing on the high mountains of Virginia and Carolina, and flowering from August to October; our plant did not agree so well with his description of the leaflets of the involucrum as could be wished, yet we think there can be no doubt but it is the same species; in our plant, these were generally bluntly rounded; he describes them as more pointed : every other part of his description perfectly agrees with our plant.

The plant from which our drawing was taken, was imported last Autumn, from North America, by Mr. Colvill; it began flowering, this year, the beginning of September, but did not ripen seeds, owing, we believe, to the dampness of the atmosphere, as plants of this genus in general seed freely; it requires to be planted in a warm border of rich light earth, and it will also be well to protect some plants of it in frames in Winter, as they are sometimes destroyed by very hard frost, except covered with straw, or glass. It may be propagated, but slowly, by dividing the root.

1. Involucre. 2. Capitulum split through the centre, to show the naked dotted Receptacle. 3. Leaflet of the Involucrum. 4. Floret, showing the pappus on the seed surrounding the tube. 5. Floret laid open, to show its villous inside, and the nerves. 6 . Stamens, showing the distinct filaments and connected anthers. 7. Seed, terminated by the Style and Stigmas. 



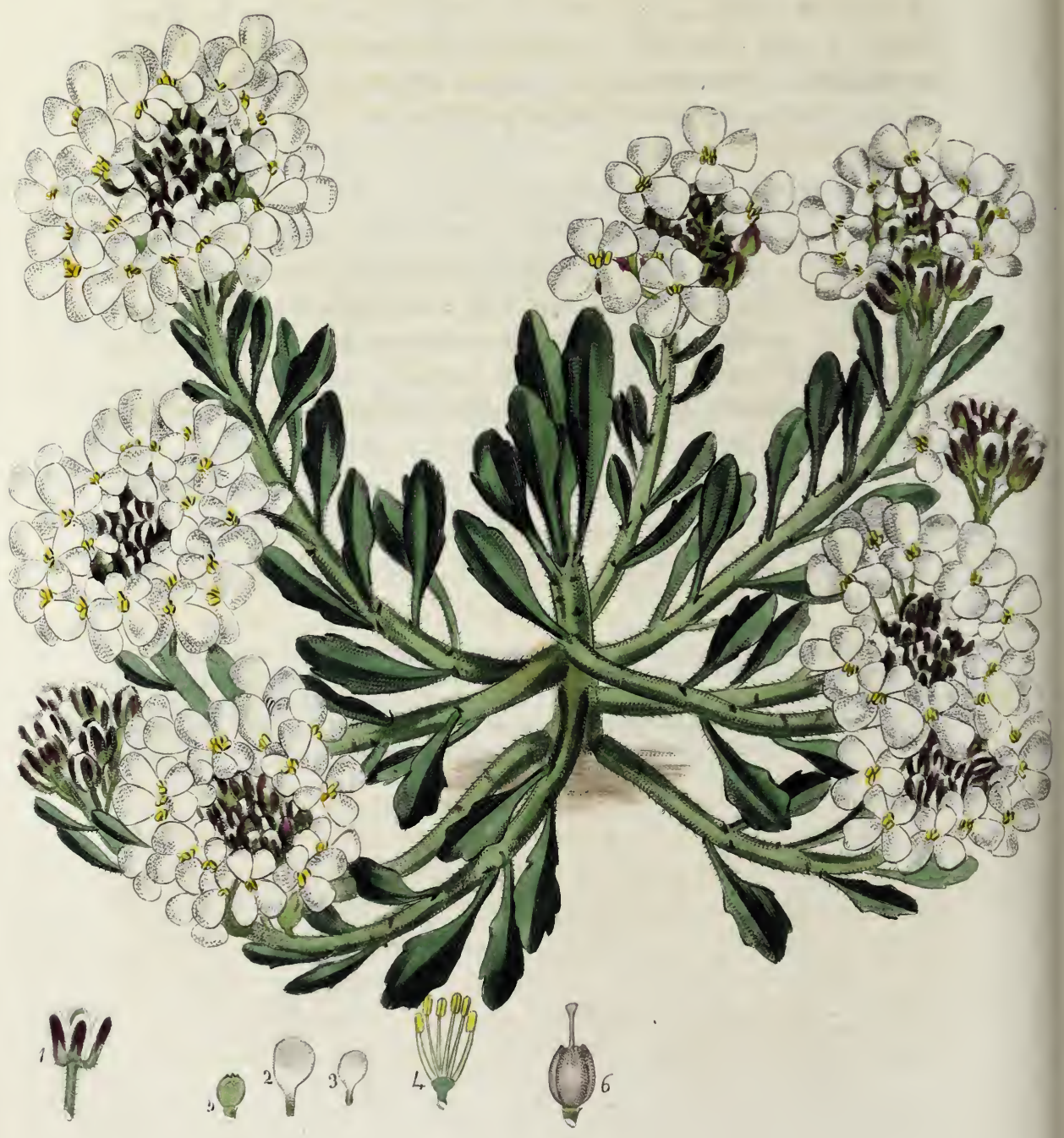




\title{
88
}

\section{IBERIS Tenoreana.}

\author{
Tenore's Candy-tuft.
}

Natural Order. CRUCifere. DC. syst. nat. 2. p. 139.

Subordo I. PleURORHIZEA. Supra fol. 46.

IBERIS. Supra fol. 50.

Sect. I. I Beridium. Radicula descendens. Semen im. marginatum. Septum simplex. DC'. prodr. 1. p. 179.

$\$ 1$. Pedicellis fructiferis corymbosis, caulibus suffrutescentibus perennibus.

I. Tenoreana, basi suffrutescens puberula, foliis subcarnosis crenatis : inferioribus obovatis basi attenuatis; superioribus oblongo-linearibus, siliculis subcorymbosis emarginatis. DC. Syst. nat. 2. p. 404. Prodr. 1. p. 179.

Iberis cepeæfolia. Tenor. prod. fl. nap. p. XXXviI, non. Lin.

Root perennial. Stems short, suffiruticose at the base, branching; branches 2 to 4 inches in length, slightly pubescent; side ones prostrate, ascending, middle ones erect. Leaves fleshy, slightly toothed, or crenate, slightly ciliate at the base; lower ones attenuated at the base into a kind of footstalk, obovate, blunt ; upper ones oblong, or inclining to linear, obtuse. Flowers umbellate, white, (sometimes purple, according to Decandolle.) Pedicles close together, densely pubescent. Calyx of 4 sepals, which are short, oblong, concave, obtuse, tipped with red, or purple. Petals 4, unequal, oblongly obovate, the outer ones 2 or 3 times larger than the inner. Stamens 6, 2 shorter than the others; filaments slender, smooth, attached to the back of the anthers. Silicles rounded at the base, 
emarginate at the apex; lobes and sinus acute. Style elongated beyond the lobes. Stigma slightly capitate.

The present little plant is well adapted for the ornamenting of rock-work, or for planting at the front of flower-borders. It was raised at the Nursery of Mr. Colvill, in 1822, from seeds received from the Continent; and several plants flowered the following May, but not so fine as they did this Summer, when they had acquired more strength; some of them bloomed again in Autumn, but not so strong as the Spring flowers; they appear to the greatest advantage before they are all expanded, as the red calyx of the unopened flowers, mixed with the white blossoms, gives it a pretty variegated appearance.

When grown in small pots, and protected in a frame, in severe weather, it will bloom much earlier in Spring, but it will not bear much artificial forcing, as it draws up very weak if kept too warm; it succeeds well in any rich light earth, or if planted in pots, a mixture of sandy loam and peat will suit it very well. Cuttings taken off in the young wood in Spring, and planted under hand-glasses, will strike root readily; it may also be raised from seeds, which are sometimes produced.

1. Calyx. 2. One of the large Petals. 3. One of the smaller ditto. 4. The 6 Stamens, 2 shorter than the others. 5. Silicle, or Pod, in a young state. 6. The same in a more advanced state, terminated by the Style and Stigma. 



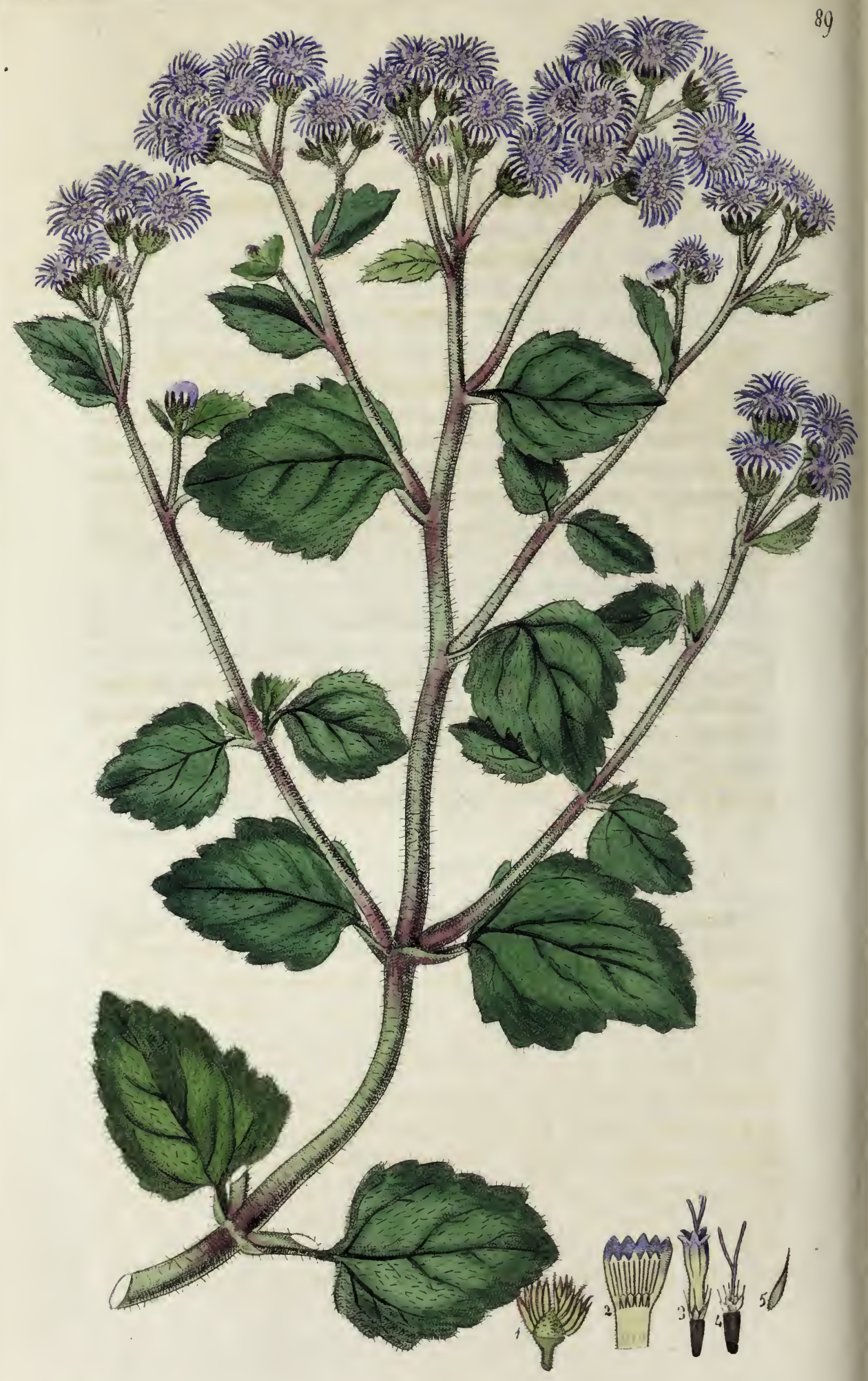




\title{
89
}

\section{AGERATUM mexicanum.}

\author{
Mexican Ageratum.
}

Natural Order. Composite. Adanson Fam. 2. 103.

Sect. III. EUPATOREAE. Kunth Synops. 2. p. 408.

AGERATUM. Involucrum campanulato-hemisphæricum, polyphyllum, subæquale, multiflorum. Receptaculum nudum. Flosculi omnes tubulosi, hermaphroditi. Anthera inclusæ. Stigma exsertum. Akenia quinquangularia, squamulis subulatis aut breviter aristatis coronata. Herbæ aut frutices. Folia opposita, integra. Flores corymbosi, violacei aut albidi. Kunth synops. 2. p. 437.

A. mexicanum, caule herbaceo ramoso diffuso; ramis adscendentibus hispidis, foliis rugosis crenatis piloso-pubescentibus obtusiusculis : inferioribus cordatis reticulato-venosis ; superioribus ovatis basi rotundatis triplinerviis, paleis pappi lanceolatis basi membranaceis apice aristatis subdenticulatis. Ageratum mexicanum. Bot. mag. 2524.

Annual, about a foot in height, much branched. Branches spreading, upper ones erect, the others ascending, hispidly pubescent. Leaves rugose, bluntish, crenate, or toothed with blunt rounded teeth, slightly hairy on the upper side, hairy and pubescent on the lower; lower ones as broad as long, petiolate, cordate at the base, reticulately veined underneath; upper ones ovate, triply-nerved, less toothed, or rarely entire, nearly sessile. Petioles deeply channelled on the upper side and rounded on the lower, glandularly hairy. Flowers paniculately corymbose, of a light blue, inclining to violet. Bractes several, some at the base of, others on the pedicles, the lower ones largest, 
lanceolate, acute; the others linear, or subulate. Pedicles slightly angular, hispid. Involucre hemispherical, many-leaved, imbricate; leaflets equal, lanceolate, taper-pointed, hairy and ciliate. Receptacle convex, naked. Florets numerous, crowded, all hermaphrodite, tubular, 4 or 5 toothed, teeth reflexed. Anthers included in the tube. Stigmas exserted, long and spreading, thickest at the points. Seeds black, 5 -angular, slender at the base, crowned with a pappus of 4 or 5 unequal lanceolate paleæ, which are flat and membranaceous at the base, and terminated by a long bristle like awn, or sometimes by 2 or 3 short teeth.

This handsome annual plant is of late introduction to our flower-gardens, the seeds having been lately brought from Mexico, by Mr. Bullock, and raised at the Nursery of Mr. Tate, Sloane Street, with many other rare and choice plants. The best method of raising it is to sow the seed early in Spring, in a hothouse, or green-house, or on a hot-bed, and to plant out the young plants in the open borders, where they will continue to flower all the Summer, and ripen their seeds. If the seeds are sown in the open ground, the plants will be later coming into flower, and there will not be so good a chance of procuring plenty of ripe seeds; to have the plants strong and healthy, they should be as much as 6 or 9 inches apart, as the branches spread considerably; they will thrive best in a rich light soil, and a sheltered situation.

Our drawing was made at the Nursery of Mr. Tate, last Summer.

1. Involucre, with the leaflets cleared from one side, to show the convex naked Receptacle. 2. Floret spread open, to show the insertion of the Stamens. 3. Seed, terminated by the floret. 4. The same divested of the floret, showing the awned pappus, and terminated by the Style and Stigmas. 5. Leaflet of the Involucre. 


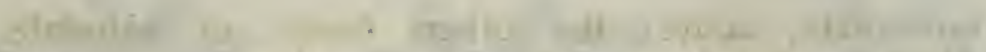

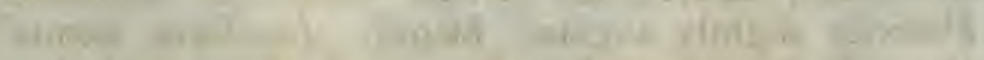

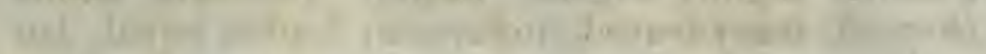

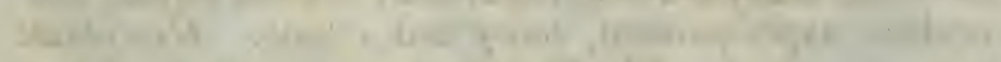

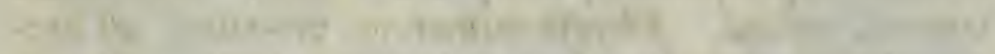

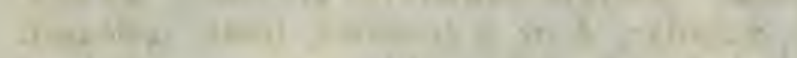

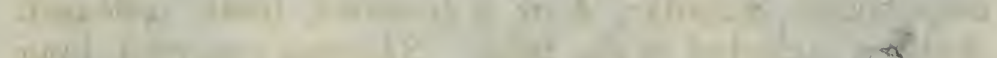

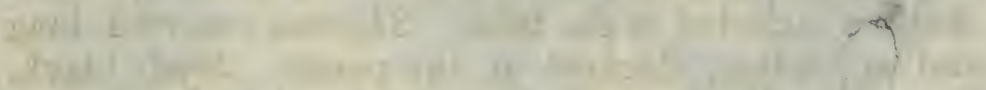

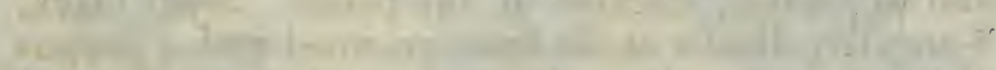

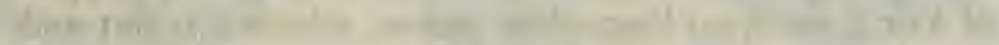

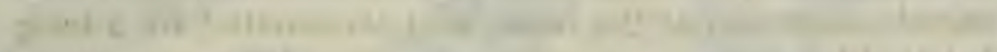

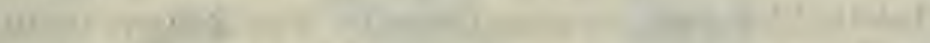

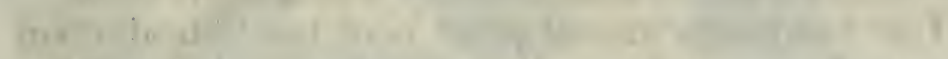

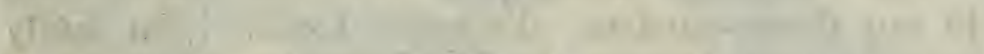

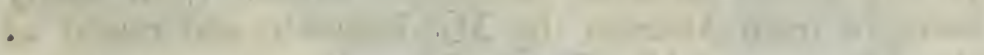

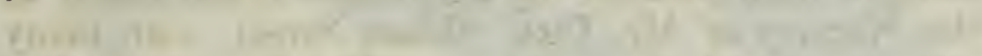

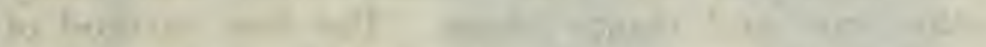

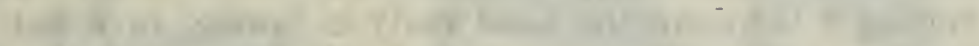

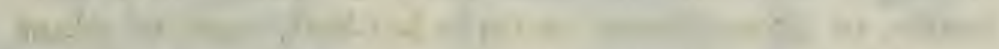

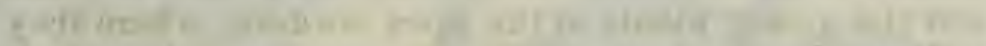

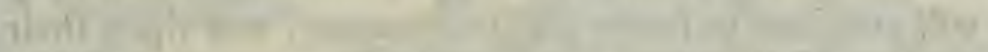

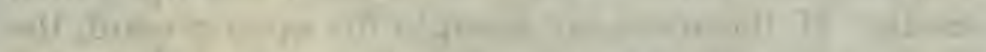

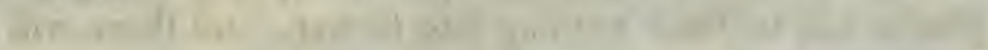

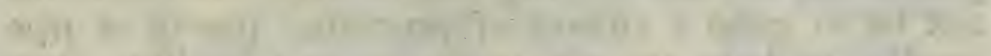

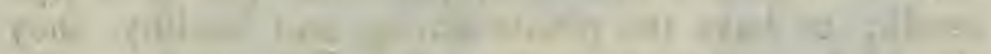

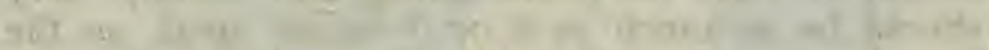

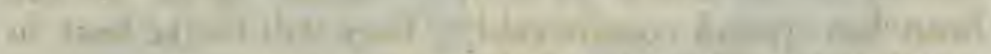

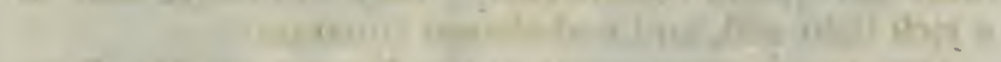

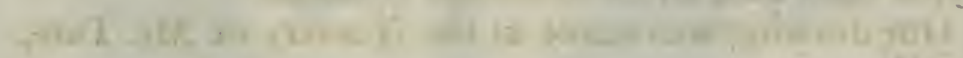

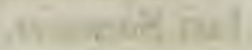

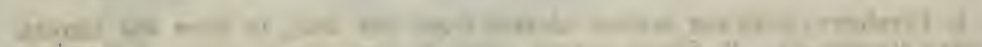
(2)

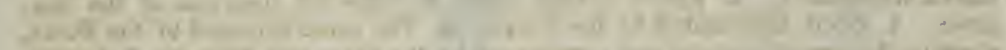

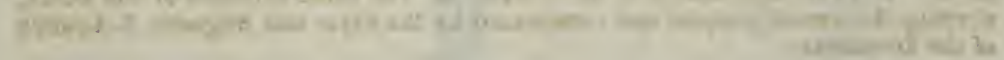




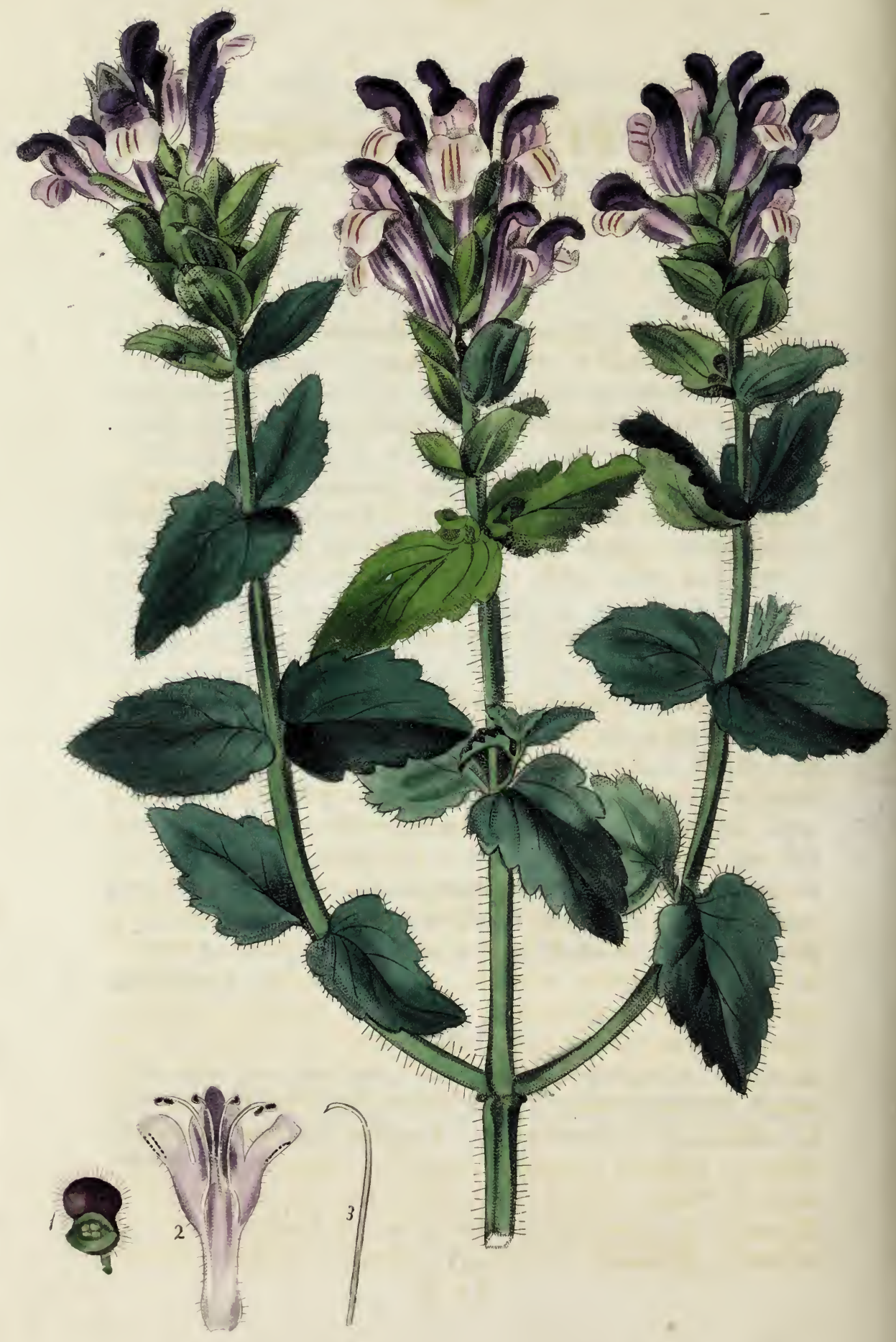




\title{
SCUTELLARIA alpina.
}

\author{
Alpine Skull-cap.
}

Natural Order. La віат有. Brown prodr. 499. SCUTELLARIA. Supra fol. 45.

S. alpina, foliis cordatis inciso-serratis crenatis, spicis imbricatis rotundato-tetragonis, bracteis flore duplo brevioribus. Willden. sp. pl. 3. p. 17. Pers. syn. 2. p. 136. Pl. rar. hung. 2. p. 146. t. 137. Hort. Kew. ed. 2. v. 3. p. 427.

Perennial. Stems spreading, quadrangular, thickly clothed with long villous hairs, branching in all directions. Leaves opposite, cordate, lower ones deeply serrate, upper ones crenate, bluntish, strongly and numerously nerved underneath, and furrowed above, hairy on both sides. Petioles short and flat, longest on the lower leaves, scarcely any on the upper, covered with long hairs. Spikes of flowers terminating the branches, 3 or 4 inches long, imbricate, roundly 4-sided. Bractes sessile, ovate, acute, cucullate, many-nerved underneath, thin and membranaceous, covered with villous hairs, about half the length of the flowers. Calyx 2-lipped, entire, villous, at first very small, but increasing in size before the fruit ripens, and in which it is enclosed. Corolla tubular, ringent, villous; helmet purple; lower lip emarginate, white, with 3 violet coloured stripes on the upper side. Stamens 4, inserted in the tube, 2 longer than the others; filaments declining, smooth; anthers incum-

2 A 2 
bent, fimbriate. Style smooth, about the length of the shortest stamens. Stigma a simple point. Seeds 4, naked, angular, enclosed in the calyx.

This pretty herbaceous plant is a native of Hungary ; it is quite hardy, and flowers from June to August, and sometimes continues in bloom till October; it seldom exceeds 6 or 9 inches in height; but the branches spread round to a considerable distance, so that it is requisite to cut it back in Winter, to keep it within bounds. It succeeds well in the common garden soil, and will grow in rather a shady situation, where many plants that are more tender will not thrive. It is readily increased by dividing at the root, or by seeds, which ripen plentifully.

Our drawing was taken from a plant at the Garden belonging to the Apothecaries' Company, at Chelsea, last Summer.

1. Calyx, opened at the mouth, to show the 4 Seeds. 2. Corolla spread open, to show the 4 Stamens. 3. Style and Stigma. 



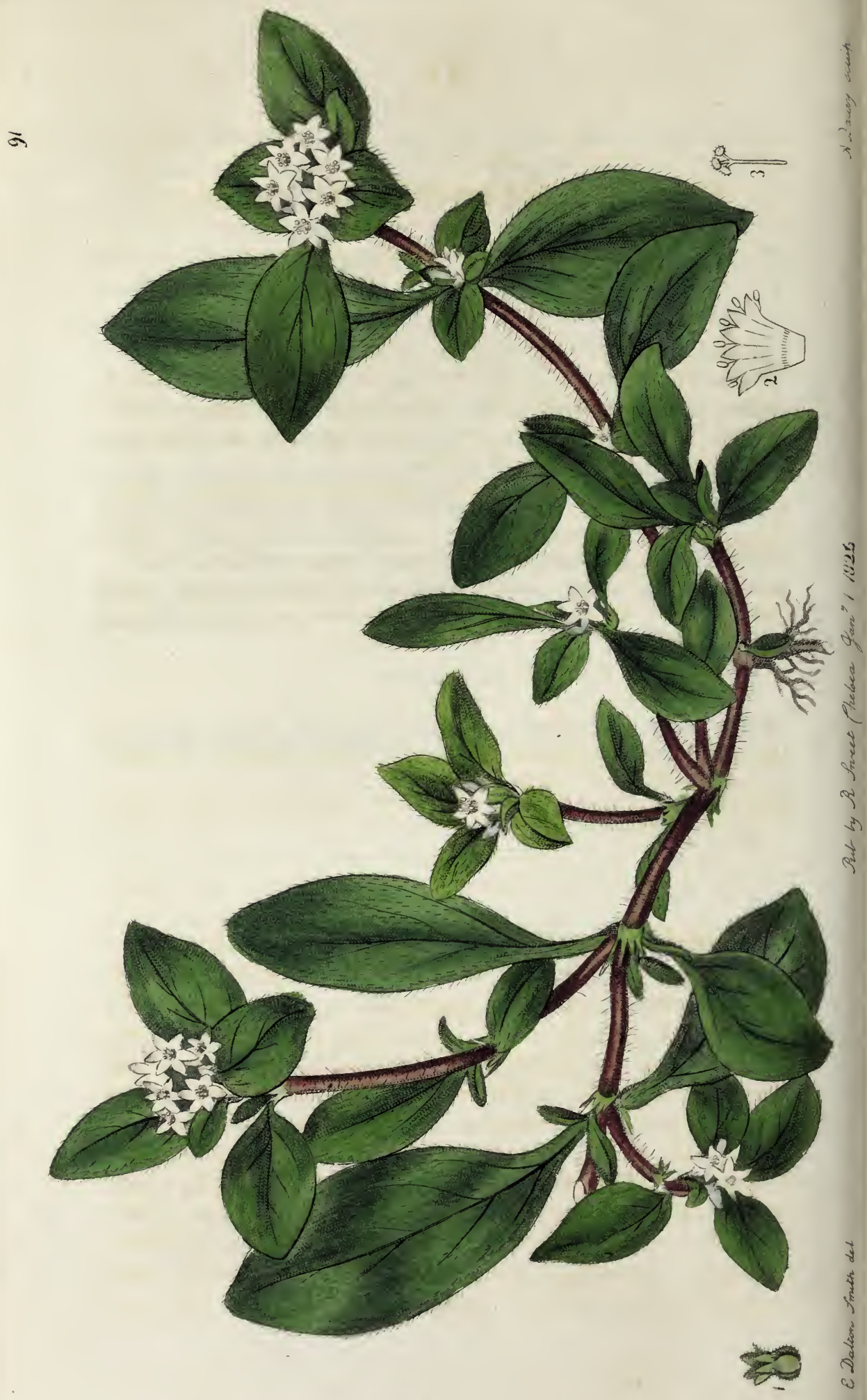




\section{RICHARDSONIA scabra.}

\section{Rough-leaved Richardsonia.}

Natural Order. Rubiacex. Juss. gen. p. 196.

Sect. II. SPERMACOCEA. Fructus bi-aut rarissime tricoccus, siccus; coccis monospermis. Stamina 4 , rarissime 5 aut 6 . Herbæ, suffrutices aut frutices. Folia opposita, mediante vagina ciliata. Kunth syn. 3. p. 14.

RICHARDSONIA. Calyx superus, 6-8-partitus; laciniis æqualibus. Corolla infundibuliformis; limbo 6-8-fido, æquali. Stamina 6-8, exserta. Ovarium tricoccum. Stylus 1, apice trifidus. Stigmata oblongo-capitata. Capsula tricocca, calyce persistente coronata; coccis 1-spermis. Herbæ diffusa, facie Spermacocis. Flores terminales, capitato-congesti, albi. Kunth syn. 3. p. 19.

R. scabra, caule hispido brachiato, foliis ellipticis nervosis scabris, involucris 2-phyllis.

Richardia scabra. Lin. sp. pl. p.470. Lam. ill.t. 254. Pers. syn. 1. p. 392.

Annual. Stems spreading, brachiate, thickly clothed with spreading unequal white hairs; branches ascending. Leaves opposite, elliptical or oval, gradually attenuated at both ends, narrowing at the base down the petioles, very rough to the touch, occasioned by numerous minute tubercles, on which grow short rigid decumbent hairs, margins ciliate, underneath strongly nerved, the nerves branching from the midrib at regular distances. Pelioles, or base of the leaf, deeply channelled on the upper side, and convex on the lower, fringed. Stipules joined to the base of the petioles, connate, sheathing the stem, membranaceous, and toothed with several sharp subulate teeth that are 
bearded at the points. Flowers terminal, white, in a close crowded head. Involucre of 2 broadly ovate sessile leaves, which are strongly and numerously nerved underneath. Calyx superior, 6 to 8 parted, segments radiately spreading, broadly lanceolate, acute, fringed. Corolla funnel-form, limb 6-parted, the segments equal, radiately spreading. Stamens 6 , inserted in the tube, and exserted beyond the mouth ; filaments stout, smooth; anthers incumbent; pollen white, granular. Style about the length of the stamens, smooth, 3-cleft at the point. Stigmas 3, oblongly capitate, rough. C'apsule 3-coccus, or 3 joined together, each producing one seed, and crowned with the persistent calyx.

This curious annual plant is a native of South America, and was raised last Summer at the Nursery of Mr. Colvill, from seeds received from Germany. It succeeds well in a warm border of rich light earth, where it should be sown about the middle of April, if the weather prove favourable; the plants will then have time to flower, and ripen their seeds; if sown later, there will not be so good a chance of the seed ripening. It seldom exceeds 6 inches in height, but spreads its branches to a considerable distance; so that the young plants should not be allowed to grow too close together, as they will injure each other, and will not thrive so well.

Our drawing was made at the Nursery of Mr. Colvill, in August last.

1. Capsule, crowned with the persistent Calyx. 2. Corolla spread open, to show the insertion of the Stamens. 3. Style cleft in three at the point, and terminated by 3 oblongly capitate Stigmas. 


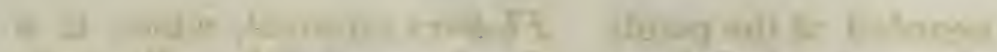

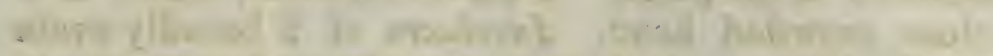

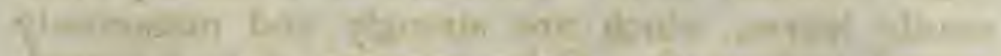

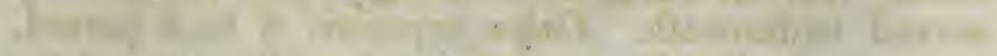

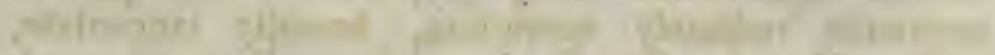

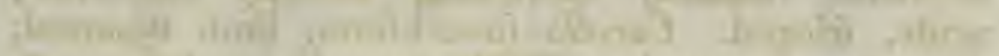

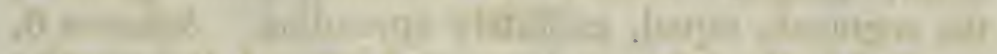

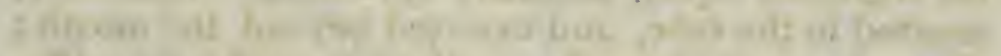

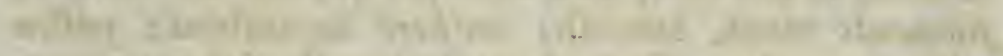
the

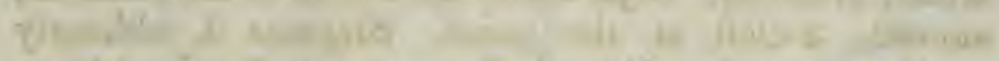

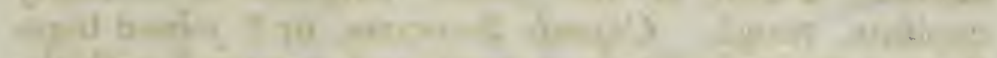

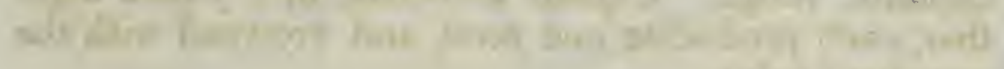

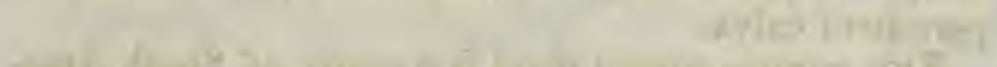

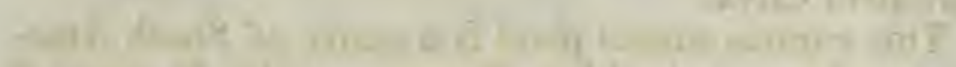

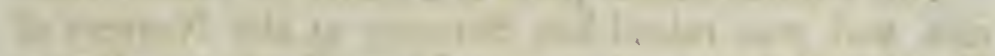

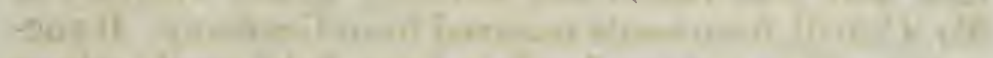

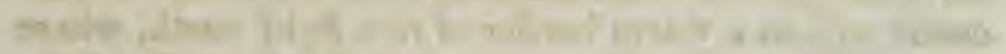

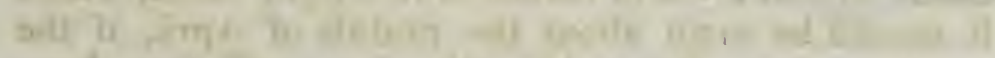

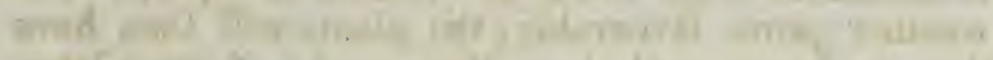

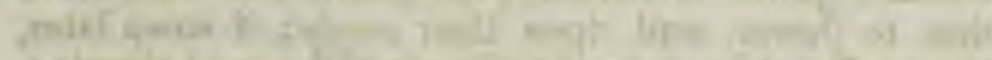

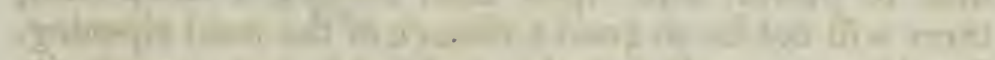

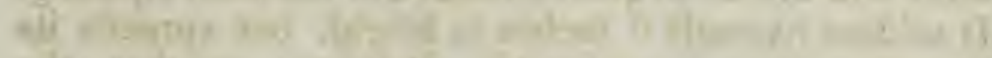

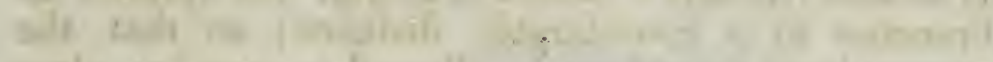

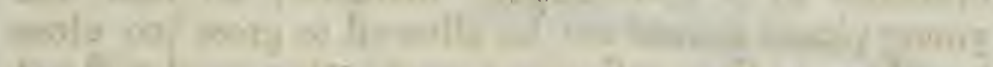

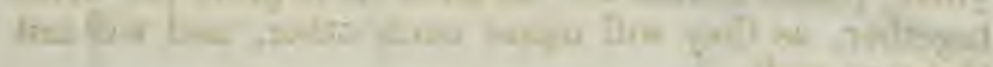
ink

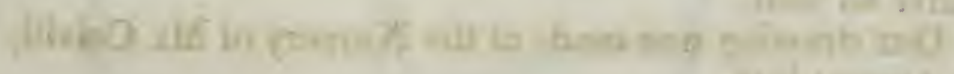
wh I f wirk, w

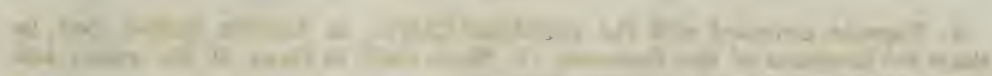

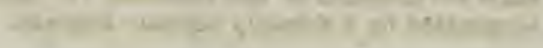




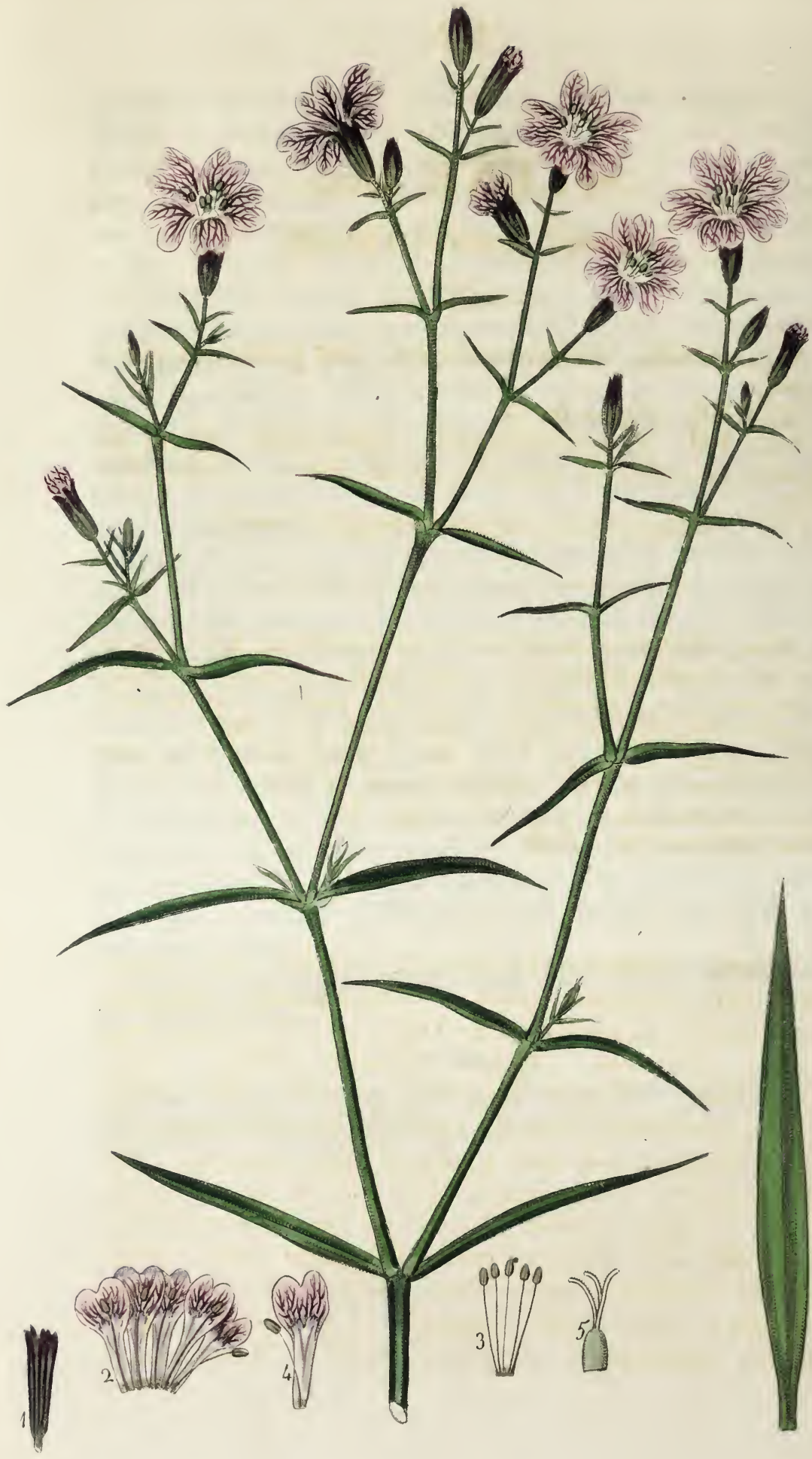




\section{2}

\section{SILENE picta. \\ Painted flowered Catchfly.}

Natural Order. CaRYophyllex. DC. prodr. syst. nat.1. p. 351.

SILENE. Supra fol. 58.

Sect. VII. Siphonomorpha. Caulescentes. Flores paniculati rarò solitarii; pedicelli oppositi breves. Calyx tubulatus.

$\S 2$. Floribus erectis, calycibus elongatis clavatis.

S. picta, caulibus ramosissimis vix pubescentibus, foliis inferioribus obovato-spathulatis : superioribus linearibus acutis, floribus laxe paniculatis, calycibus clavatis rubro-striatis, petalis bipartitis reticulatis. DC. prodr. 1. p. 380 .

Silene picta. Pers. syn. 1. p. 498. Willd. enum. 1. p. 477. Link enum. 1. p. 426. Steudel nomen. p. 779.

Silene anastomosans. Lag. gen. et spec. 15.

Silene Reinwardtii. Roth.

Annual. Stems erect, from 2 to 3 feet high, much branched; branches erect, dichotomously panicled, very slender, knotted at the joints, smooth and glossy, slightly glaucous. Leaves opposite, linear, acute, channelled. Flowers elegantly painted with purple stripes, proceeding from the upper forks of the branches, which lengthen out and produce other flowers. $P e-$ duncles short, some longer than others, nearly cylindrical. Calyx tubular, slender at the base, clavate, 5-toothed, and striped with 10 purple lines; teeth purple. Petals 5, unguiculate, the unguis longer than the calyx ; limb bifid, elegantly striped with purple, darkest underneath, all joined together at the mouth 
by the crown; crown on each petal bifid, decurrent down the unguis, each segment 4-toothed. Stamens 10, every other one attached to the base of the petal, the others inserted in the receptacle; filaments smooth, gradually tapering upwards; anthers attached by the back, a little above the base, 2-celled. Germen smooth. Styles 3, roughened inwards.

Our drawing of this elegant annual plant was taken in September last, at the Nursery of Mr. Colvill, where it was grown in the open air with other hardy annuals. It may be considered an Autumn flowering plant, as it continues to bloom till the frost destroys it. The seeds should be sown early in Spring, otherwise there will be no chance of obtaining ripe seeds; the beginning or middle of April, if the weather permits, is the best time for sowing them; they will succeed well in any common garden soil, and they require to be a good distance apart, as they grow to the height of from 2 to 3 feet, and branch round to a considerable distance, each plant should be as much as $\mathbf{9}$ inches apart, otherwise they will crowd each other, and will not thrive near as well. It is not at present ascertained of what country the present subject is a native, but from its habit we suspect it to be either Barbary, or the South of Europe.

1. Calyx. 2. The 5 Petals spread open, showing the 5 Stamens, each attached to the base. 3. The other 5 Stamens inserted in the receptacle. 4. Petal, showing the toothed Crown. 5. Germen, terminated by the 3 Styles and Stigmas, the latter a little roughish on the inward side. 


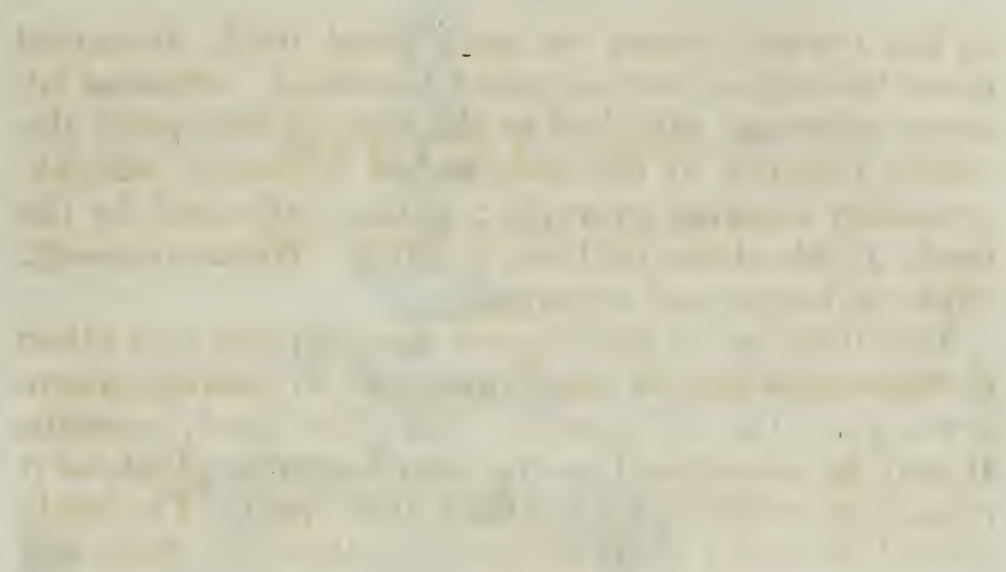

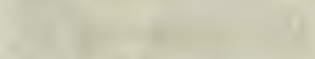

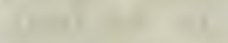

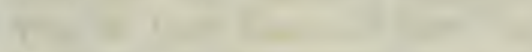

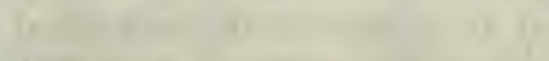

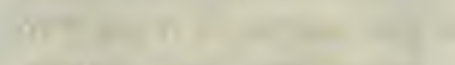

$-1+2$

(1)

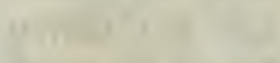

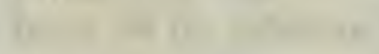

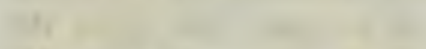

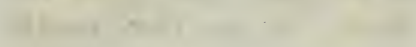




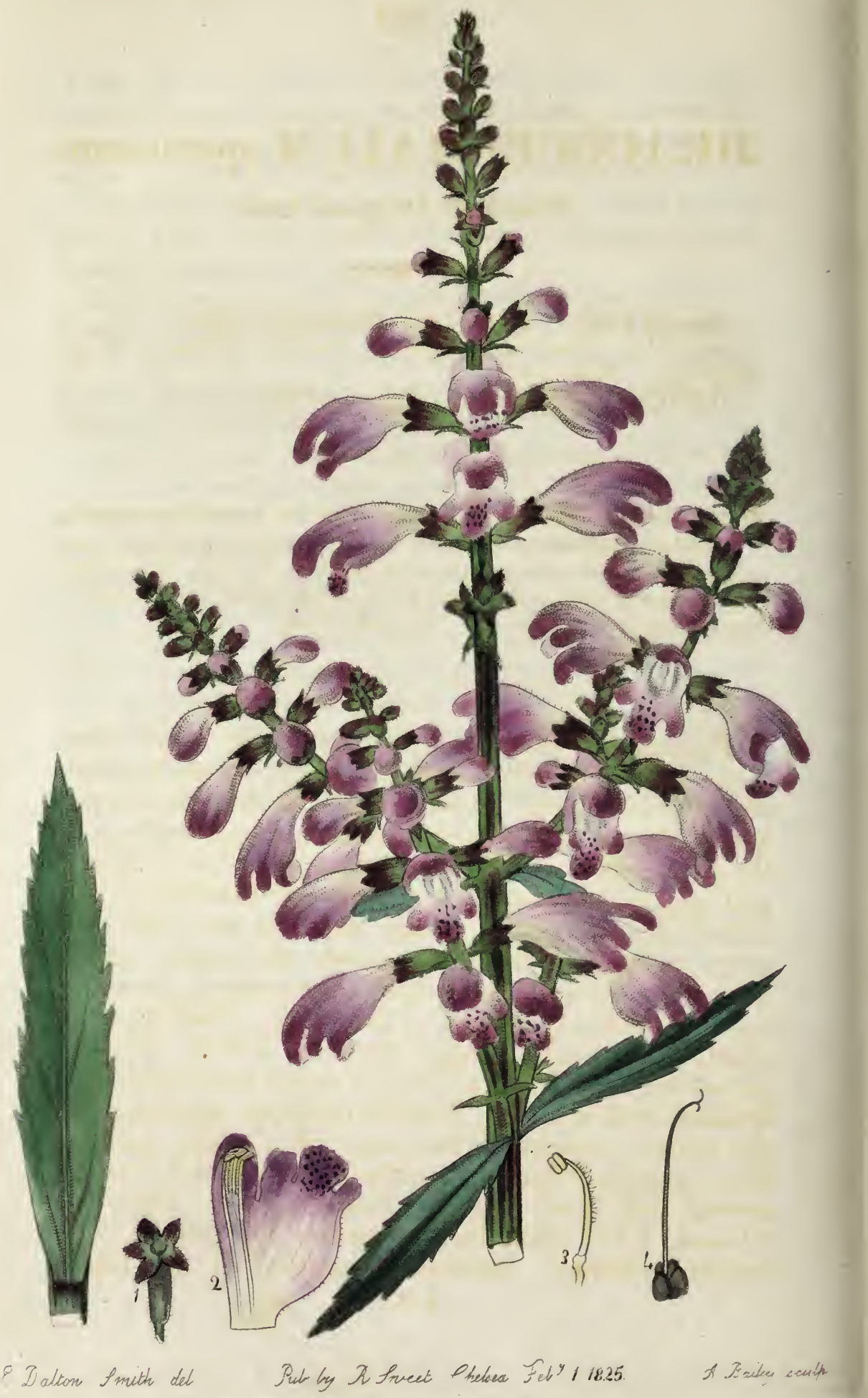




\title{
DRACOCEPHALUM speciosum.
}

\author{
Beautiful Dragon's-head.
}

Natural Order. La biata. Brown prod. 499.

Sect. IV. Stamina 4 fertilia. Corolla bilabiata. Calyx bilabiatus. Juss. gen. 115.

DRACOCEPHALUM. Supra fol. 38.

D. speciosum, caule erecto obtuse tetragono paniculato-ramoso, foliis lato-lanceolatis sessilibus argute serratis basi integerrimis, spicis elongatis tetragonis confertifloris, bracteis lanceolatis acuminatis, calycis dentibus acutis inferioribus longioribus.

Dracocephalum speciosum. Hortulanorum.

Perennial. Stems several from the same root, 3 to 4 feet high, erect, much branched, bluntly 4 -sided, smooth and glossy. Leaves sessile, broadly lanceolate, acute, deeply and sharply serrated, particularly near the point, entire at the base, rather succulent, smooth and glossy, many-nerved, the nerves branching, but rather inconspicuous. Spikes more or less panicled, erect, regularly 4-sided, elongated, the flowers rather crowded. Bractes lanceolate, taper-pointed, broad at the base, scarcely as long as the calyx. Pedicles very short, pubescent. Calyx tubular, 5-cleft, slightly pubescent : segments acute, the upper one rather the broadest and shortest. Corolla bilabiate, inflated near the mouth, slender at the base, of a bright reddish lilac, strongly veined at the back, from which branch several pale lines: upper lip entire, arched: lower lip 3-lobed, lobes spreading, truncate, the middle one largest, reflexed. Stamens 4, inserted in the tube, 
2 rather longer than the others: filaments bearded: anthers incumbent, 2-celled: pollen white. Style smooth. Stigma 2-cleft, with acute points.

This fine species of Dracocephalum is a native of North America, and has been introduced to our gardens within these few years, where it has always been cultivated under the name that we have adopted, but we do not find it any where recorded. It belongs to the same section of the genus as D. denticulatum, and 1). virginianum, but is readily distinguished from both by its panicled habit.

The spikes of flowers in this species are regularly 4-sided, although, when growing in the garden, the flowers are often seen to be all facing one way; this is owing to the short and weak pedicles, and the weight of the flower, keeping it so firm on the bracte, that whatever way the wind blows it, there it remains; so that when the wind blows strong from any quarter, the flowers are always facing the opposite direction. If a branch is cut off and held in the hand, the flowers may be moved by the other hand in the same manner, either all to one side, or some to one side, and some to the other, and wherever they are placed, there they will remain.

Our drawing was taken from a fine plant, in September last, at the Nursery of Messrs. Whitley, Brames, and Milne, at Fulham. It succeeds well in the open ground in a rich light soil, where it will attain the height of 3 or 4 feet; and it may be readily increased by dividing at the root.

1. Calyx. 2. Corolla spread open, to show the insertion of the Stamens. 3. One of the Stamens detached. 4. The 4 Seeds with the Style between them, terminated by a cleft Stigma. 



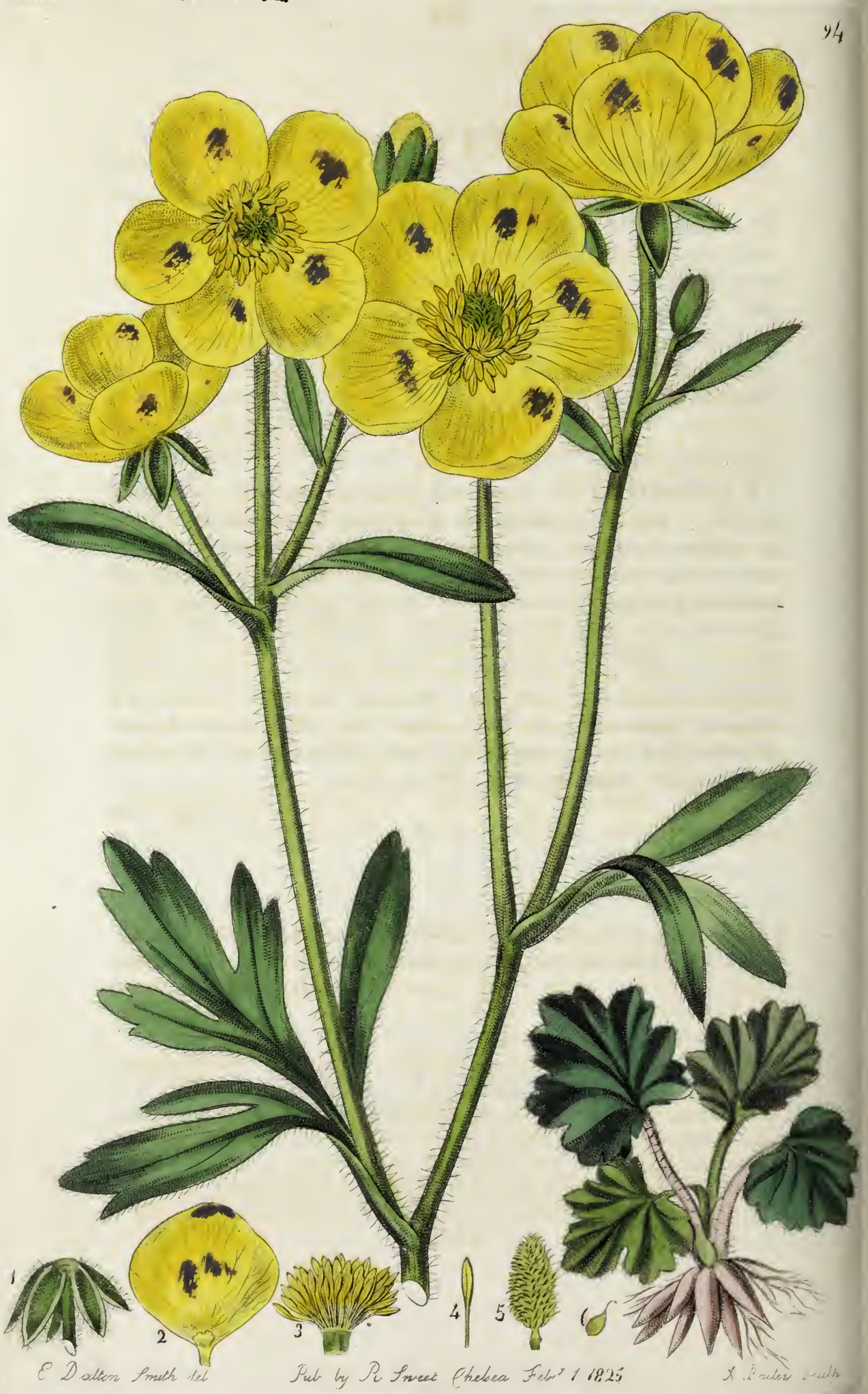




\section{RANUNCULUS monspeliacus.}

\section{var. $\beta$. cuneatus.}

\section{Wedge-lobed Montpelier Crowfoot.}

Natural Order. Ranunculacea. DC. syst. v. 1. p. 127. Tribus III. RANUNCULEA. Fstivatio calycis et corollæ imbricata. Petala bilabiata aut intùs squamulâ ad basin aucta. Carpella 1-sperma sicca indehiscentia. Semen erectum. Folia radicalia aut alterna. DC. p. 130.

RANUNCULUS. Calyx 5-sepalus, sepalis basi non solutis deciduis. Petala 5 rarius 10 intùs basi squamulâ foveolâve nectariferâ instructa. Stamina ovariaque numerosa; Cariopsides ovatæ subcompressæ, in mucronem aut cornu semine vix longius desinentes, læves striatæ aut tuberculatæ, in capitulum globosum cylindraceumve dispositæ. Herbæ annuc aut sapiùs perennes. Radices fibrosa, fasciculate aut grumosa; caules teretes, erecti procumbentes aut interdìm radicantes; folia integra dentata aut multifida, pleraque radicalia, caulina ad originem ramorum pedunculorumque sita. Pedunculi terminales axillares aut oppositifolii; flores albi aut lutei, rarissime purpurei, ferè omnes inodori. DC. p. 231.

Sect. II. RANUNCULASTRUM. Carpella lævia compressa, in spicam digesta. Radix grumosa. DC. prodr.1. p. 27.

R. monspeliacus, foliis lanuginosis; radicalibus trilobis ; lobis cuneatis trifido-dentatis; superioribus tripartitis; lobis integris linearibus, caule erecto pauciflora, calyce reflexo, carpellorum spica ovata. DC. syst. 1. p.260. Prodr. 1. p.28. Swt. hort. brit. p. 5. ined.

a angustilobus, lobis foliorum angustis elongatis. R. illyricus. Besl. syst. vern. ord. 1. t. 13. f. 1 . Willden. enum. 589.

ß cuneatus, lobis foliorum cuneiformibus apice trifido-dentatis. R. monspeliacus. DC. ic. gall. rar. t. 50. R. apiifolius. Desf. in pict. liort. par. 37. $i$. 73. non Pers.

$\gamma$ rotundifolius, foliis rotundatis trifidis, lobis dentatis obtusis. R. monspeliacus. Gou. fl. monsp. 279. Poir.dict. 6. p. 111. 
Roots clustered, tuberous, with fibres intermixed. Leaves at first nearly round, 3-lobed, lobes 2 or 3-toothed; the next are deeply 3-lobed, or 3-parted; the lobes or segments cuneate, trifid or dentate; upper ones 3-parted, segments linear, entire, or 3-toothed, all thickly covered with villous canescent down. Petioles a little flattened, and furrowed on the upper side, and rounded on the lower; the upper ones sheathing the peduncles, villous. Stem erect, from 6 inches to a foot in height, from 3 to 9-flowered. Peduncles cylindrical, downy. Calyx of 5 sepals, deciduous; sepals ovate, obtuse, concave, villous, reflexed. Petals 5, very large, broadly obovate, of a light yellow. Stamens numerous; filaments slender, smooth, attached to the base of the anthers, which are about the length of the filaments. Spike of seeds ovate. Seeds flat, smooth, obliquely taper-pointed.

A native of Montpelier, and, according to M. Decandolle, a very variable species; but that seems to be chiefly owing to the situation in which it grows. It is generally known in our gardens by the name of R. philadelphicus, but how it came by that appellation we have not ascertained. In a rich light soil, it will attain a foot in height, and produce about 9 flowers on a stalk; in poorer soil, it will be considerably less; the flowers are very large, of a bright yellow, and very ornamental, and the roots are very similar to the common garden Ranunculus, R.asiaticus. It thrives well in the open air, in the common garden soil, and readily increases by dividing at the root.

Drawn at the Nursery of Mr. Colvill, the beginning of last June.

1. The reflexed Calyx. 2. One of the Petals. 3. Stamens inserted in the Receptacle. 4. Stamen detached. 5. Spike of Seeds. 6. Seed detached. 


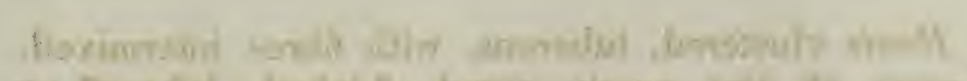

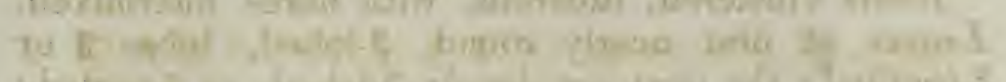

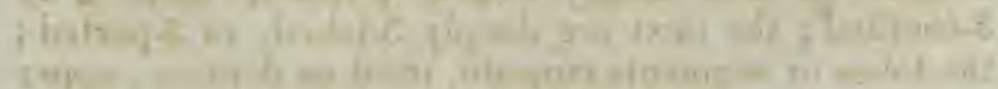

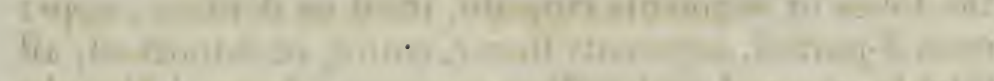

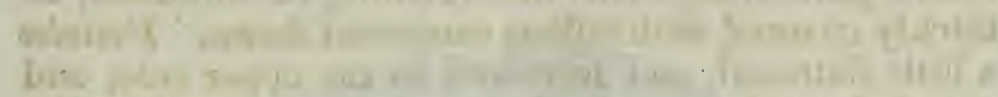

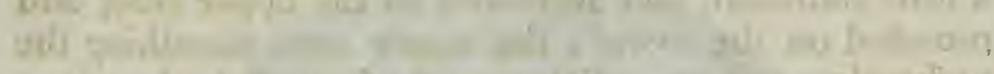

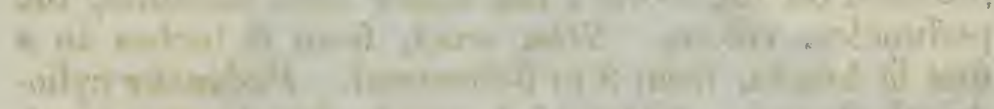

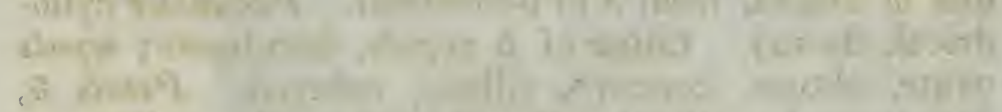

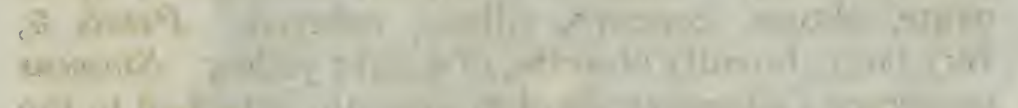

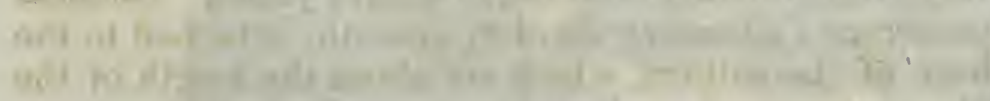
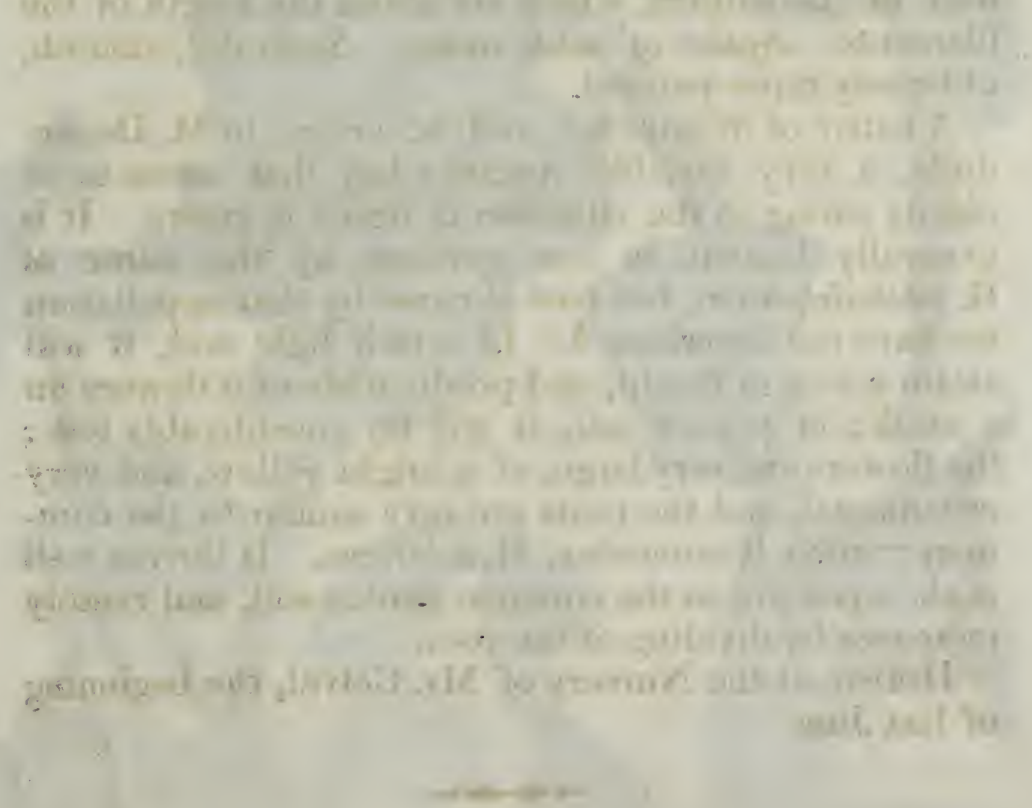

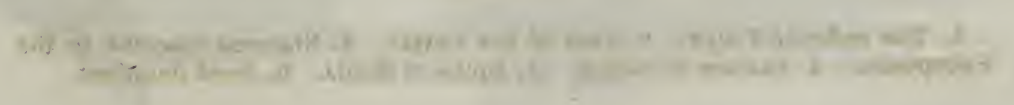




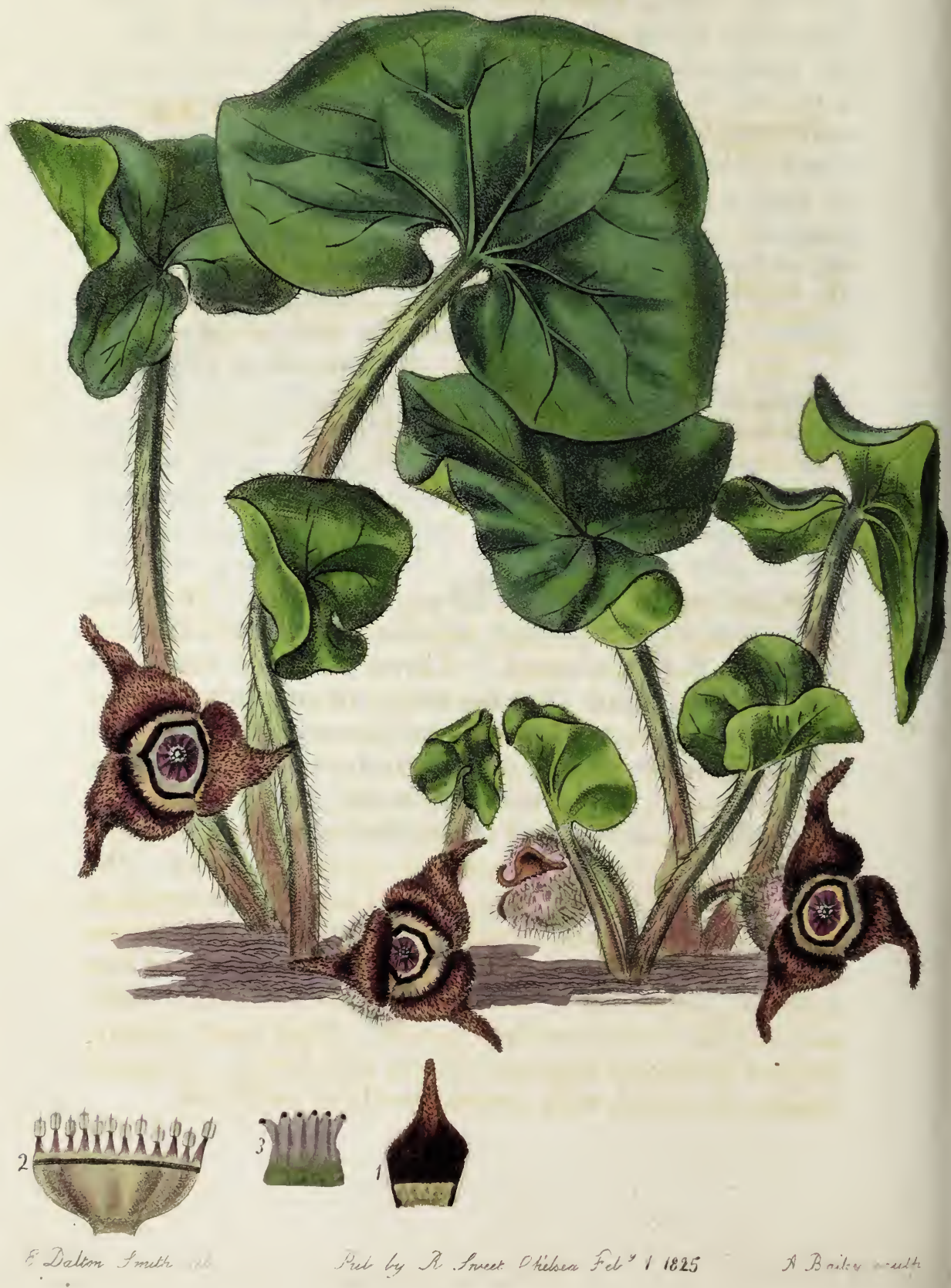




\section{5}

\section{ASARUM canadense.}

Canadian Asarabacca.

Natural Order. ARistolochie. Brown prodr. 349. ASARUM. Supra fol. 18.

A. canadense, foliis lato-reniformibus geminatis, perianthium lanatum profunde tripartitum : laciniis sublanceolatis reflexis. Asarum canadense. Mich. fl. amer. 1. p. 279. Willd. sp.pl.2. p. 838. Lam. ill. t. 394.' f. 2. Pers. syn. 2. p. 1. Pursh. fl. amer. 2. p. 596. Lodd. bot. cab. 889. Asarum carolinianum. Walt. flor. car. 143. Asarum latifolium. Salisb. prodr. 344.

Roots tufted, fibrous, of a spicy scent. Branches short, simple, spreading, terminated by 2 leaves, and a flower between them. Leaves broadly reniform; while young, acute, but becoming bluntly rounded by age, very soft to the touch, pubescent on both sides ; sinus generally overlapping at the base. Petioles stout at the base, and tapering upwards, flattened on the upper side, and rounded on the lower, densely clothed with villous down. Flowers on short footstalks. $P e$ duncles cylindrical, villous, nodding. Perianthium campanulate, villous, deeply 3-parted, of a pale brown colour ; laciniæ lanceolate, taper-pointed, more or less reflexed, sides rolled back. Stamens 12 , every other one longest, seated on the capsule. Style short, fleshy. Stigma stellately 6-parted, blunt, and fleshy. Capsule inferior, 6-celled, with several seeds in each cell. 
A native of North America, growing, according to Pursh, in shady rocky situations, from Canada to Carolina; " the root is highly aromatic, and known by the inhabitants of those countries by the name of Wild Ginger." With us it is quite hardy, producing its curious flowers in May, and thriving well in a light sandy soil, in a shady situation; this makes it the more desirable, as it will thrive where many other plants will not; its branches are short, but have an inclination to spread; the leaves are large, and the footstalks densely clothed with long villous hairs; this is not represented in Mr. Loddiges' figure.

Our drawing was taken from a plant that we received from the Nursery of Messrs. Whitley, Brames, and Milne, in May last. It is readily increased by dividing at the root.

1. One of the segments of the Perianthium. 2. The 12 Stamens spread open, to show their insertion, every other one longest. 3. The large 6 cleft Stigma. 


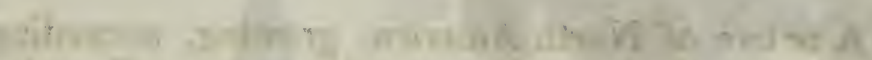

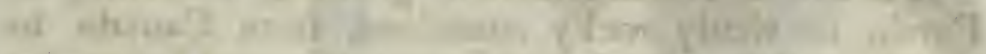

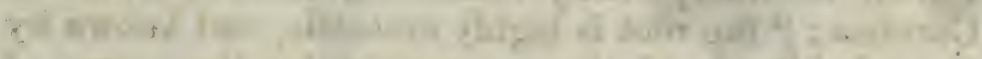

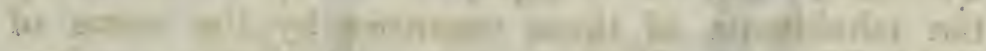

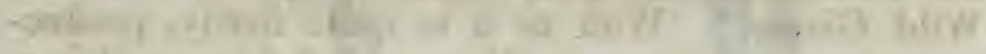

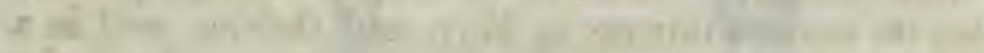

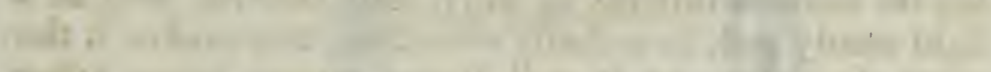

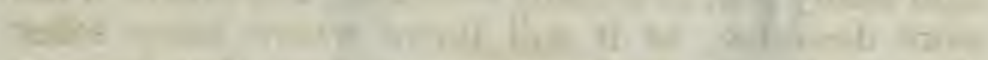

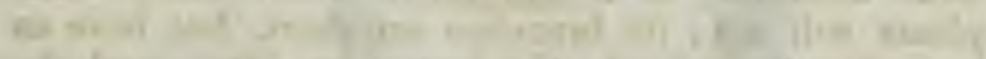

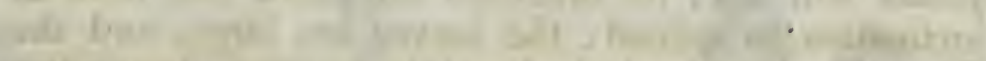

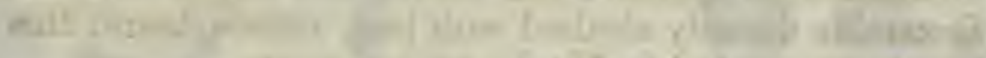

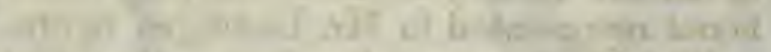

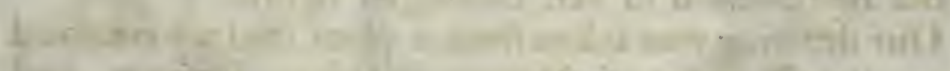

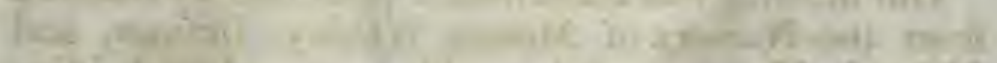

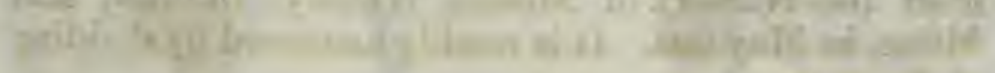

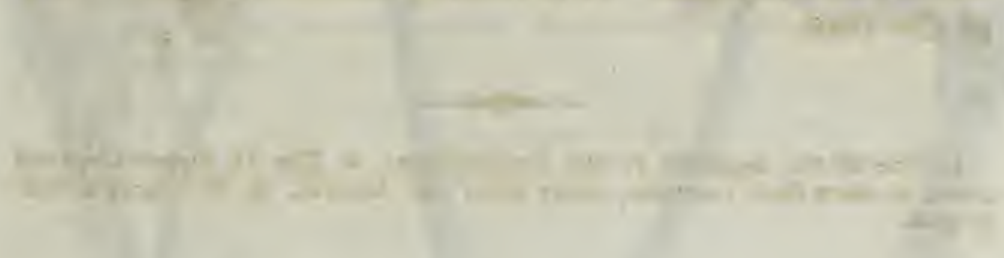




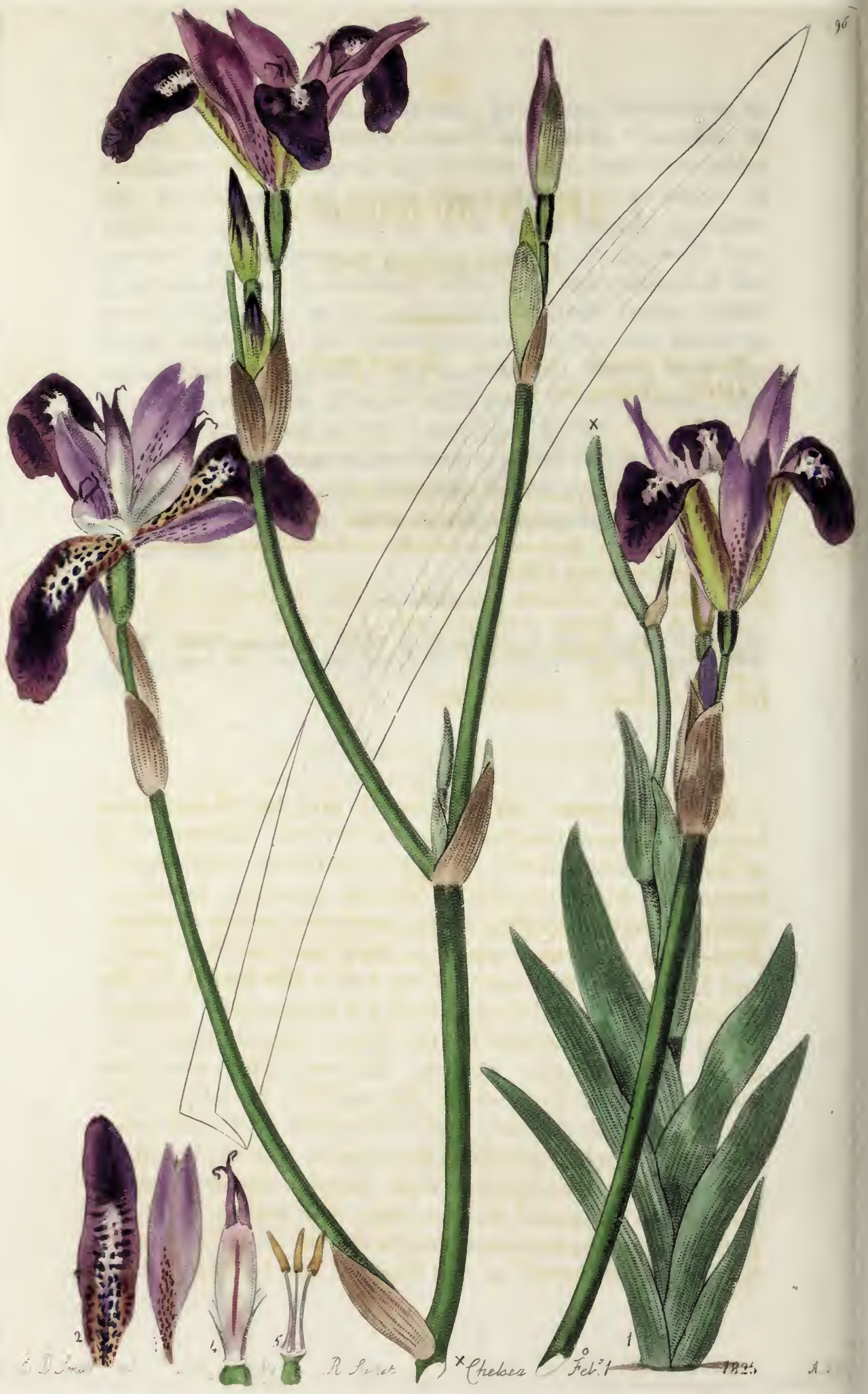




\title{
96
}

\section{IRIS dichotoma.}

\author{
Forked-petaled Iris.
}

Natural Order. IRIDEA. Brown prodr. 302.

IRIS. Supra fol. 68.

I. dichotoma, foliis ensiformibus falcatis, scapis teretibus paniculato-ramosis, spathis terminalibus diphyllis multifloris, perianthii tubo fere nullo: laciniis exterioribus subbarbatis; interioribus apice bifidis.

Iris dichotoma. Willden.sp. pl.1. p. 230. Pallas it. 3. p.712. t. A. f. 2. Rom. et Schult. syst. 1. p. 464. Pers. syn. 1. p. 52. Hort. Kew. ed.2. v. 1. p.120. Bot. reg. 246. Link enum. 1. p. 58.

Iris pomeridiana. Fischer Mss.

Root tuberous. Stem from a foot to 18 inches in height. Leaves ensiform, more or less falcate, of a white glaucous colour. Scape cylindrical, paniculately branching, leafy, smooth. Sheaths terminal, 2-leaved, many-flowered: leaflets ovate, concave, points scariose. Peduncles long and slender, flattened on the inside, and keeled on the outer, about twice the length of the sheath. Germen oblong, bluntly 3-cornered. Perianthium divided nearly to the base into 6 segments; outer ones linearly oblong, obtuse, with crenulate points, reflexed from about the middle, of a light purple tinged with brown, and variegated near the base, with a large white patch in the centre, slightly bearded, and more or less spotted with purple; inner segments obovate, attenuated to the base, the points bifid, or forked, and sometimes toothed, of a light purple. Stamens 3, inserted in the base of the laciniæ, about 
half the length of the stigmas: filaments flat, smooth : anthers linear, 2-celled: pollen pale yellow. Style short. Stigmas 3, petal-like, channelled at the back, and keeled inwards, deeply bifid, the segments taperpointed and twisted.

This beautiful and very distinct species of Iris, in habit, approaches the genus Pardanthus, and appears to be the connecting link between the two genera. It also differs from all the other known species, in the expansion of its flowers, those never opening till the afternoon, which occasioned Dr. Fischer to give it the appropriate name of I. pomeridiana. It is a native of Dahuria, but is rather more tender than some other species, suffering much from an over abundance of moisture, so that it should be planted in a dry open situation, and in a light soil, where the wet will pass off readily ; it is also well to preserve some plants of it in pots, to be placed in frames in very wet or very cold weather; they can then be planted in the borders in Spring. It may be increased by seeds, or by dividing at the root.

Our drawing was taken from a very strong plant, at the Chelsea Botanic Garden, last Summer, where it was raised from seed that Mr. Anderson received from Dr. Fischer.

1. Reduced figure of the Plant, showing how the scape terminates the Branch. 2. One of the outer leaflets of the Perianthium. 3. One of the inner ditto, showing its forked point. 4. Stigma, showing its bifid point, and the twisted tips. 5. The 3 Stamens. 


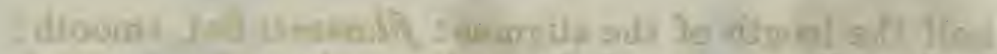

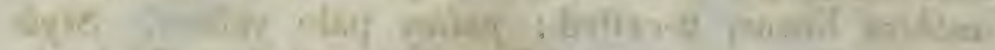

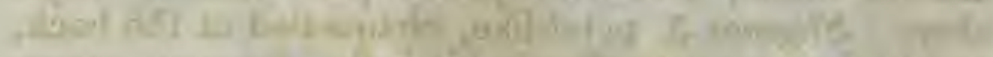

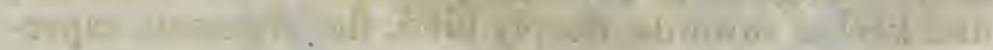

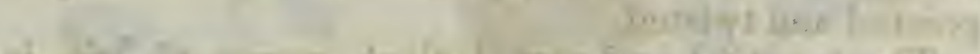

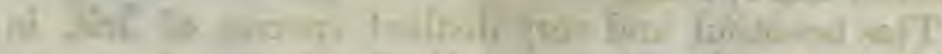

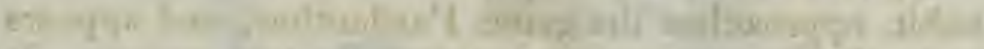

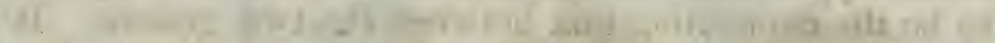

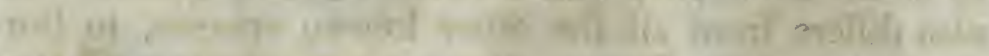

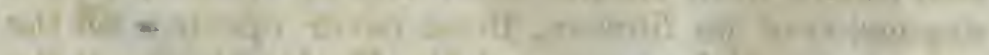

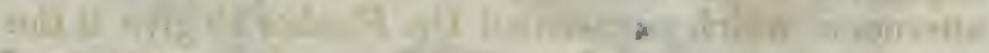

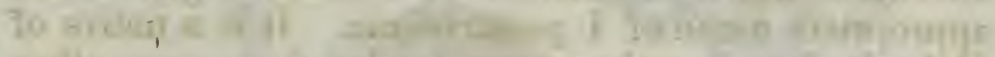

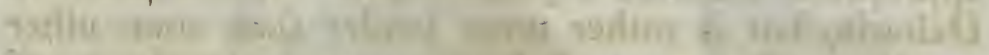

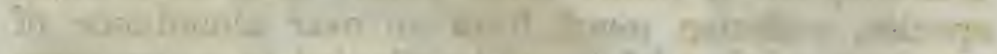

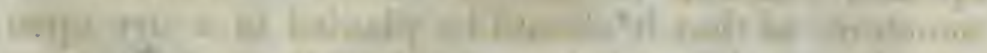

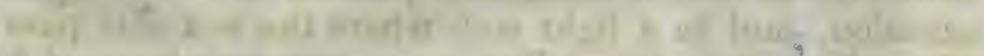

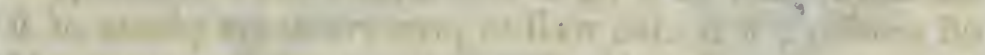

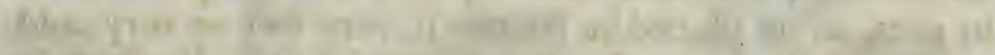

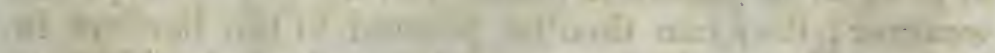

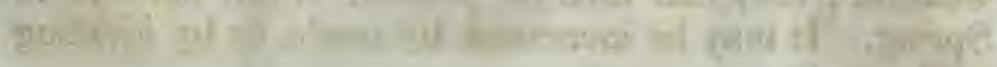

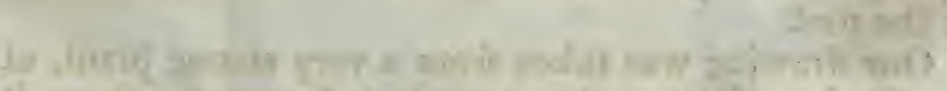

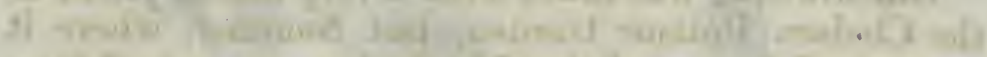

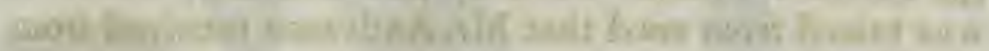
This 1 nol

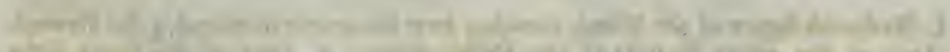

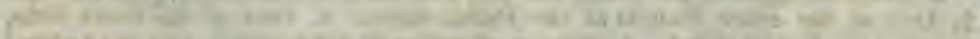

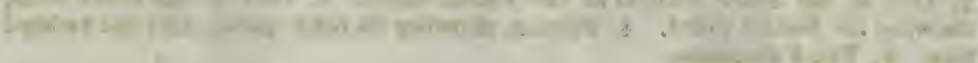




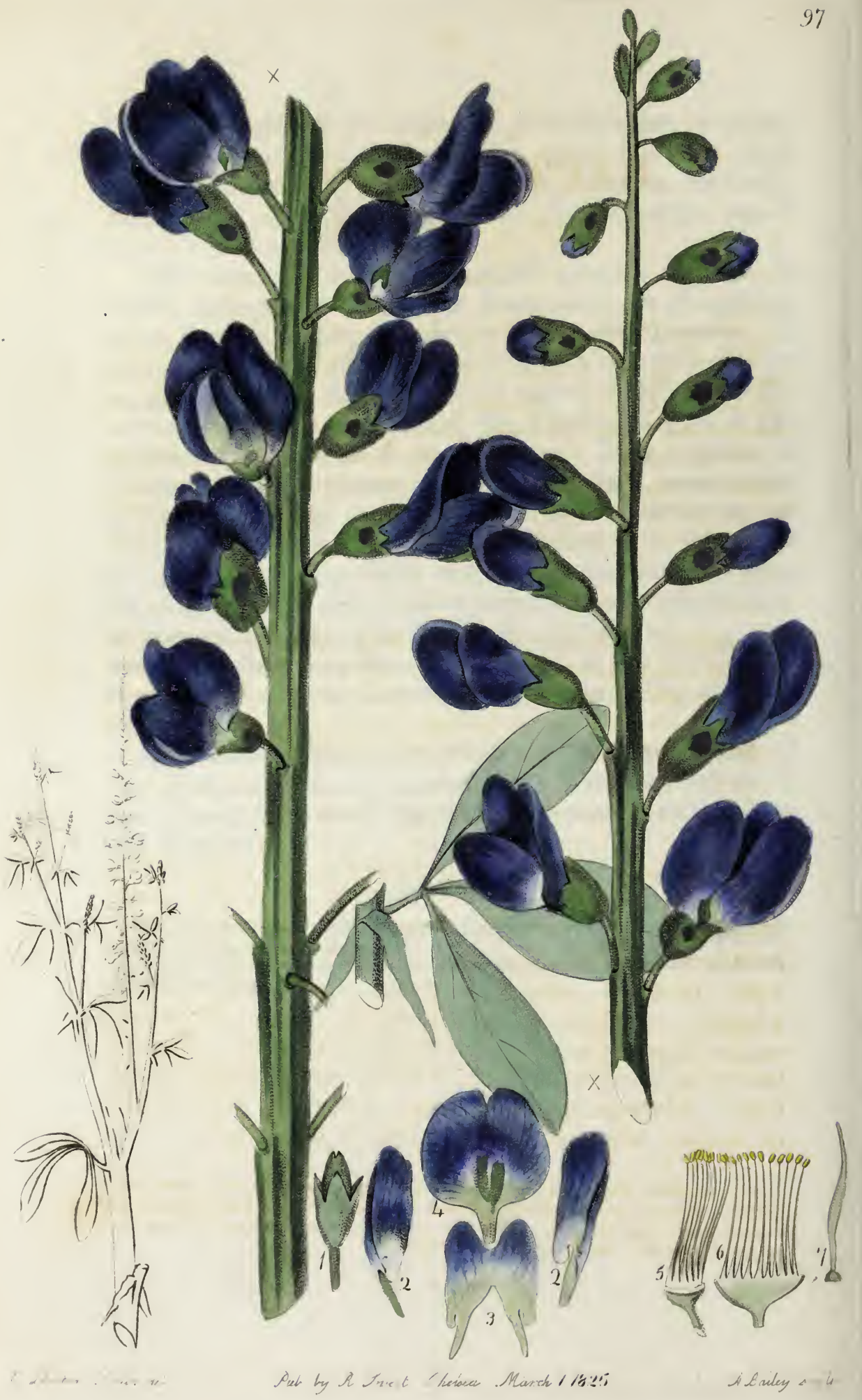




\title{
BAPTISIA exaltata.
}

\author{
T'all upright Baptisia.
}

Natural Order. Leguminose. Juss. gen. 345.

Div. IV. (PAPILIONACEA.) Corolla irregularis papilionacea. Stamina distincta, aut rarò basi coalita. Legumen uniloculare bivalve. Frutices aut herba; folia simplicia aut ternata aut impari-pinnata. Juss. gen. 351.

BAPTISIA. Calyx semi-4-5-fidus, bilabiatus. Corolla papilionacea, petalis longitudine subæqualibus: vexillum lateribus reflexis. Stamina 10, decidua. Legumen ventricosum, pedicellatum, polyspermum. Brown. Hort. Kew. ed.2. v. 3. p.5.

B. exaltata, caule erecto ramoso, foliis ternatis petiolatis ; foliolis lanceolato-obovatis petiolo quintuplo longioribus, stipulis lanceolatis acuminatis petiolo triplo longioribus, racemis multifloris elongatis ramis duplo longioribus, floribus sparsis distantibus, calyce 4-fido: laciniis inferioribus acutis.*

Perennial. Stems several from the same root, erect, branching, when in flower from 3 to 4 feet high; branches erect, smooth, furrowed. Leaves ternate, petiolate, smooth, glaucous : leaflets lanceolately-obovate, bluntish, about 3 inches long, and scarcely 1 broad. Peliole about half an inch long, channelled on the upper side, and rounded on the lower. Stipules lanceolate, taper-pointed, 3 times longer than the petiole. Raceme very long, many-flowered, above 2 feet in length when in flower, double the length of the

- B. unstralis, caule ramoso diffuso, foliis ternatis brevissime petiolatis: foliolis oblongo.cuneatis obtusis petiolo quadruplo longioribus, stipulis lanceolatis acutis petiolo duplo longioribus, racemis paucifloris ramis brevioribus, calyce quadrifido: laciniis inferioribus obtusis. 
branches. Flowers scattered, solitary, or in pairs, distant, of a dark blue colour. Pedicles about the length of the calyx. Calyx 4-cleft, segments scarcely as long as the tube; upper one longest, emarginate; lower ones acute. Corolla papilionaceous: petals 4, nearly equal, connivent, unguiculate, eared above the unguis, the inner ones of a lighter colour : vexillum shorter than the petals, unguiculate, emarginate, channelled inside, and keeled at the back, sides scarcely reflexed. Stamens 10: filaments distinct, smooth, nearly as long as the petals, included between them, attached to the back of the anthers: anthers 2-celled : pollen yellow. Style smooth. Stigma a simple point.

The present stately perennial plant is a native of North America, and was introduced from thence in the year 1812, by the late Mr. John Lyons, at the sale of whose plants it was sold by the name of Podalyria exaltata; we were afraid that it was again lost to our collections, until we were agreeably surprised, the year before last, in seeing it growing very strong, and flowering luxuriantly, in the Apothecaries' Garden, at Chelsea, where our drawing was taken. It is readily distinguished from B. australis, by its much stronger and upright growth; the latter species was growing beside it in the same collection, so that the difference was readily perceptible; we do not know that the present species exists in any other collection. It succeeds well in the open air, in the common garden soil; and we have no doubt but it might be increased by dividing at the root, in the same manner as B. australis; we also believe it would produce perfect seeds, if pains were taken to fertilize the stigmas with the pollen, when in bloom.

1. Calyx. 2. The 2 ala, or wings, of the Corolla. 3. The Keel spread open. 4. Vexillum. 5. The 10 Stamens. 6. The same spread open. 7. The young Pod terminated by a smooth Style, and simple Stigma. 



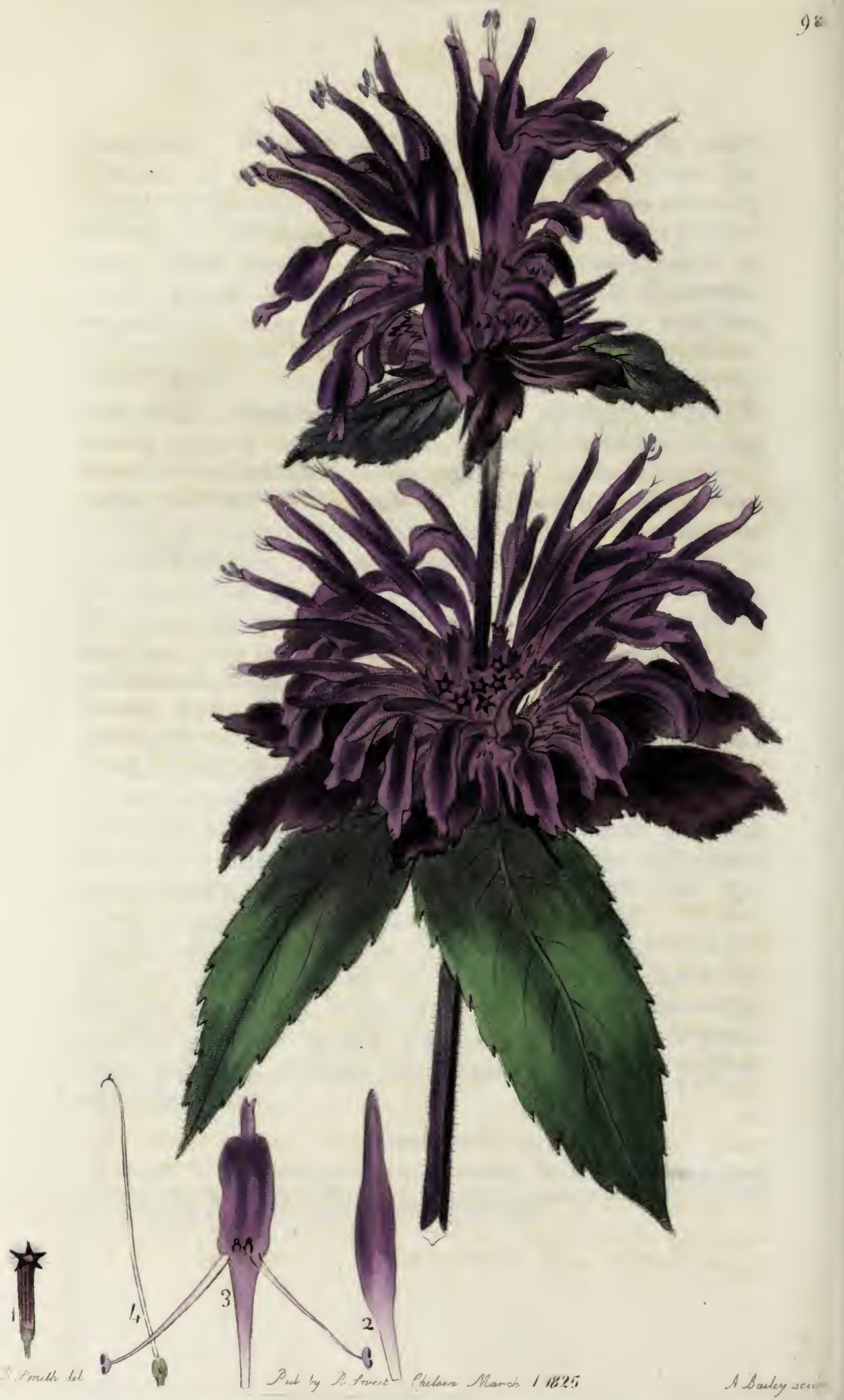




\title{
98
}

\section{MONARDA media.}

\author{
Bright Purple Monarda.
}

Natural Order. Labiate. Brown prodr. 499.

Sect. I. Stamina 2 fertilia; v. dum 4 fertilia. Antheræ omnium dimidiatæ.

MONARDA. Calyx cylindricus striatus 5-dentatus. Corolla cylindrica longior bilabiata: superius recta angusta integra, filamenta simplicia involvente; inferius reflexa latior 3-loba lobo medio longiore. Flores axillares verticillati, aut capitati terminales.

M. media, caule obtusangulo pubescente, foliis cordato-ovatis acuminatis grosse serratis rugosis supra nitidis subtus pubescentibus, capitulis magnis subproliferis, bracteis coloratis ; exterioribus ovatis acuminatis serratis ; interioribus lanceolato-linearibus integerrimis, labio inferiore lobo medio bifida. Monarda media. Willden. enum.1. p. 32. Link enum.1. p.9. Hort. sub. lond. p. 6

Stems erect, bluntly quadrangular, from 18 inches to 2 feet in height, branched, slightly pubescent, of a dark purple colour. Leaves opposite, cordate, ovate, taper-pointed, sharply serrate, rugose; upper side of a glossy green, underneath pubescent, particularly on the nerves, points a little reflexed. Petioles short, deeply channelled on the upper side, and convex on the lower, very hairy. Flowers in a close compact head, of a bright purple, the upper ones expanding first. Involucre of several purple-coloured bractes; the outer ones ovate, acuminate, sharply serrate, pubescent; inner ones much narrower, lanceolate, or linear, entire, and terminated in a long taper point. 
Caly $x$ cylindrical, 5-toothed, striate, bearded between the teeth, the teeth erect, rigid, of a dark purple. Corolla tubular, very slender at the base, gradually widening upwards, 2-lipped, pubescent: upper lip straight, narrow, the point slightly reflexed, bent in at the sides so as to enclose the stamens: lower lip broader, 3-lobed, side lobes short, obtuse, middle one long, cleft at the point. Stamens 2 , fertile, and the rudiments of 2 barren ones, which are very small and gland-like, all inserted in the tube: filaments very slender, smooth, longer than the corolla: anthers joined by their back to the filaments, connected. Style smooth, longer than the stamens. Stigma bifid, the divisions unequal, slightly reflexed.

A beautiful hardy perennial plant, native of North America, but when first introduced to this country we have not ascertained, but believe it was first brought home by Mr. Lyons; it is not described by Mr. Pursh, or Nuttall, in their Floras of North America, nor is it amongst Mr. Pursh's specimens now preserved in Mr. Lambert's Herbarium, which, by the kindness and liberality of the owner, we were permitted to examine ; the first account of the plant we find published, is in Willdenow's enumeration of the plants cultivated in the Botanic Garden at Berlin, where it had probably been received from the English Gardens. It is a very desirable plant for the flower garden, both from the beauty of its flowers, and its agreeable fragrance. It thrives well in the open air, in the common garden soil, and is readily increased by dividing at the root.

Drawn at the Nursery of Mr. Colvill, last Summer.

1. Calyx. 2. Upper lip of the Corolla. 3. Lower lip of ditto, showing the 2 fertile Stamens bent back, and the 2 barren ones between them. 4. Germen, Style, and Stigma. 


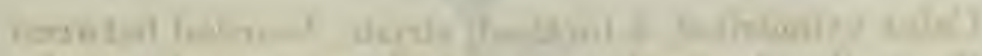

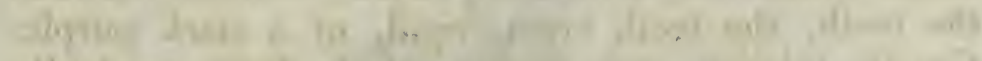

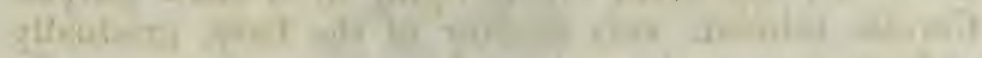

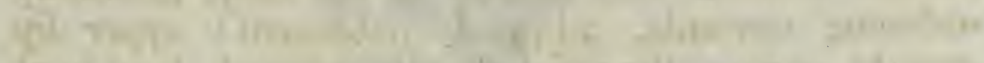

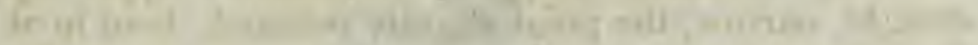

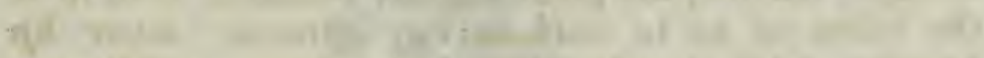

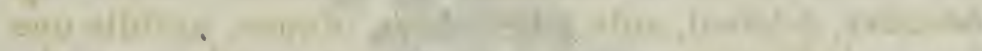

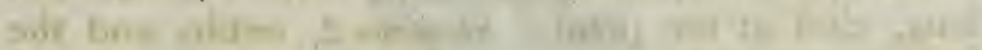

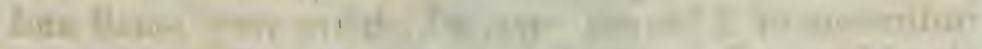

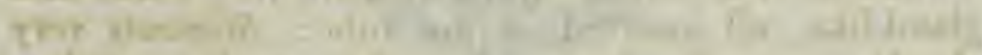

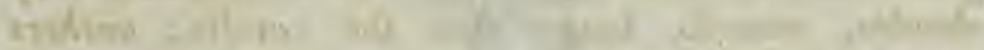

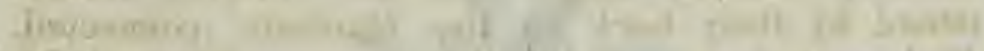
thash

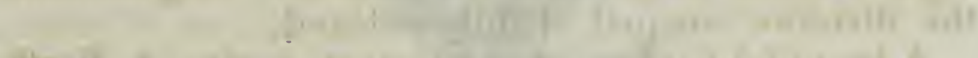

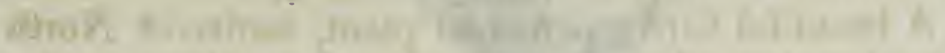

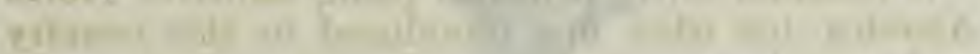

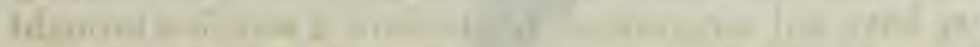

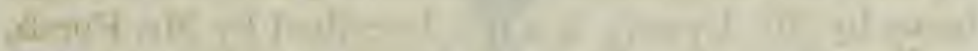

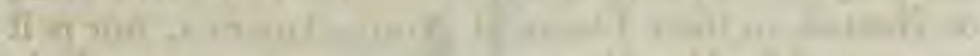

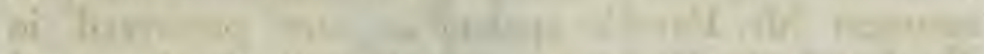

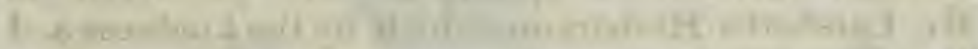

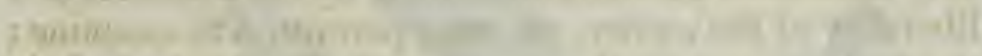

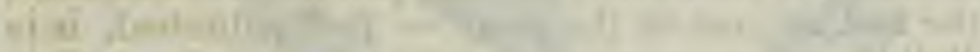

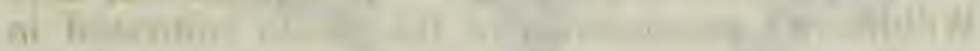

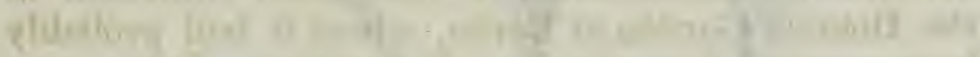

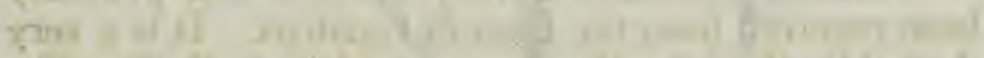

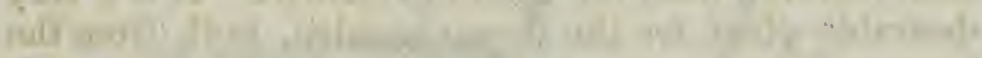

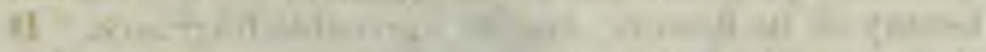

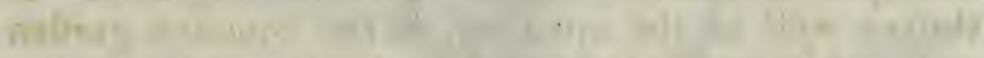

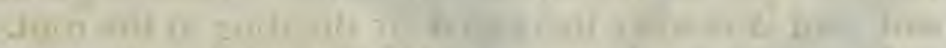

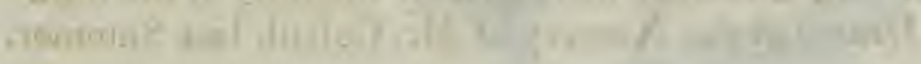

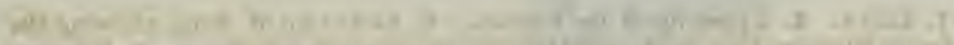

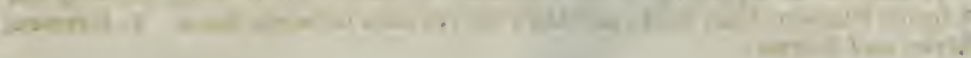




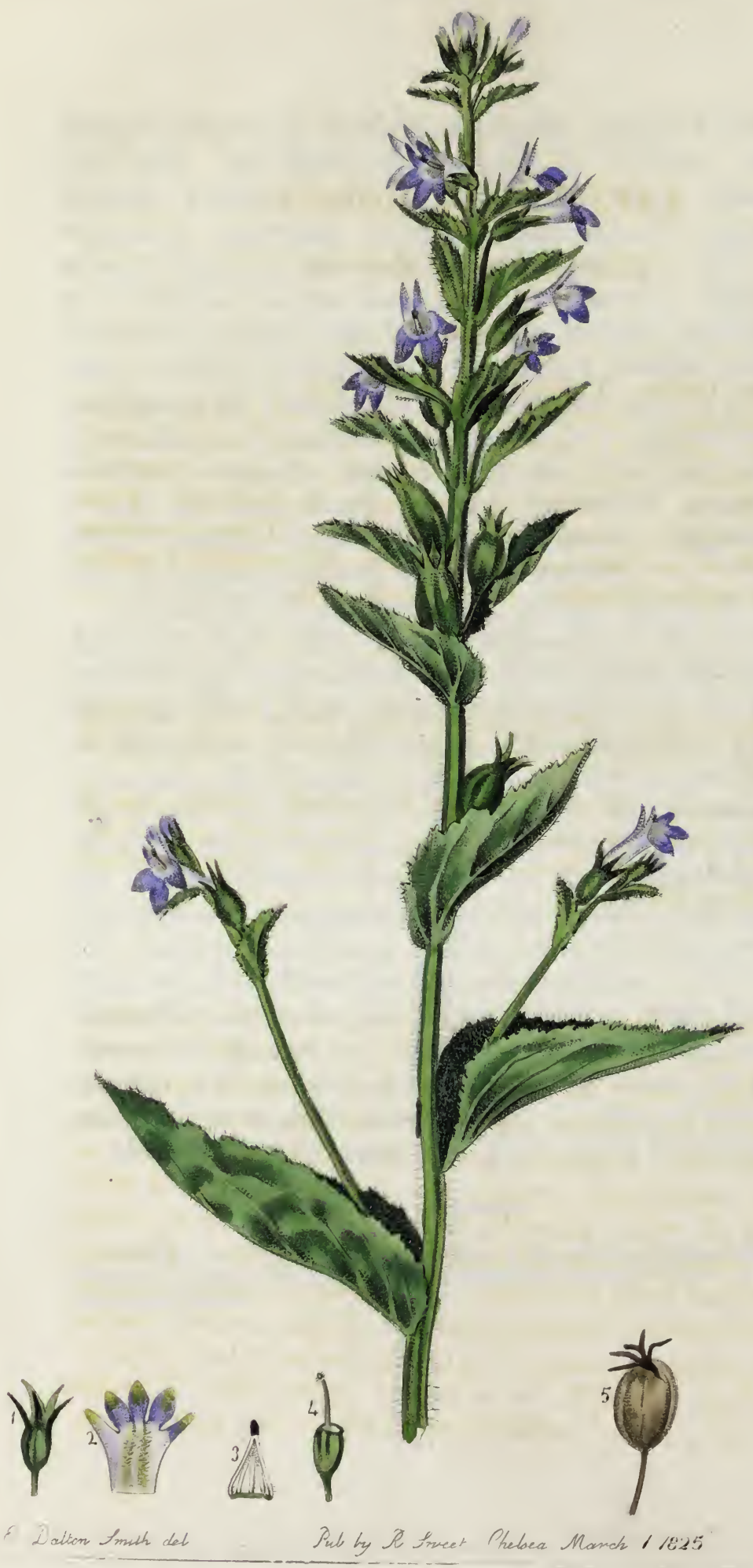




\title{
LOBELIA inflata.
}

\author{
Bladder-podded Lobelia.
}

Natural Order. Lobeliaces. Jussieu.

LOBELIA. Corolla tubo hinc fisso (rarò integro;) limbo 5-partito. Anthera connatæ. Stigma bilobum (nunc indivisum.) Capsula bilocularis (raro 3-locularis,) apice supero bivalvi.-Herbæ (v. Suffrutices) pleraque lactescentes. Folia alterna, integra v. laciniata, rarò fistulosa. Flores racemosi terminales, $v$. axillares solitarii, pedicellis bibracteatis $v$. nudis. Antheræ sapius barbata. Brown prodr. 562.

L. inflata, erecta, ramosa, hirsutissima, foliis ovatis serratis, racemis foliosis, capsulis inflatis. Pursh fl. amer. sept.2. p. 448.

Lobelia inflata. Willden. sp. pl. 1. p. 946. Pers. syn. 2. p. 213. Nutt. gen. amer. 2. p.77. Linn. in act. upsal.1741. p.23. t. 1. Hort. Kew. ed.2. v. 1. p. 359. Riem. et Schult. syst. 5. p. 53.

Annual. Stem erect, branching, very hairy, purple at the base, from 1 to 2 feet high; branches slender, spreading, hairy at the base, and smooth upwards. Leaves ovate, sessile, running down the stem in a wing on each side, concave, acute, the margins folded inwards, undulately serrate, the serratures tipped with a kind of white glands, more or less hairy on both sides, strongly nerved underneath, rugged. Flowers in terminal leafy racemes. Peduncles slender, shorter than the leaves, without bractes. Calyx 5-cleft, seated on the inferior germen, segments linear, taper-pointed, spreading, smooth, or scarcely pubescent. Corolla pale blue; tube longitudinally cleft on the upper side, 
h airy within, and bearded at the mouth ; limb 5-parted, upper laciniæ erect, or slightly reflexed, linear, acute; lower ones ovate, bluntish, spreading. Stamens 5; filaments distinct, hairy at the base : anthers connected. Germen ribbed. Style smooth. Stigma 2-lobed, fringed. Capsule inflated, nearly globular, crowned with the calyx.

Our drawing of this pretty annual plant was taken at the Nursery of Mr. Colvill, last Autumn, where it was raised from seeds received from North America. It is quite hardy, and may be sown in the open borders the latter end of March, or beginning of April; it prefers a rich light soil, and an open situation, as much exposed to the sun as possible; for if it grow in too shady an aspect, the seed will scarcely come to perfection, as its time of flowering is late in the season. It might also be sown in pots early in Spring, and brought forward in a greenhouse, or frame, and afterwards planted into the borders; by that means the plants will flower earlier, and the seeds will be more likely to come to maturity.

1. Calyx. 2. Corolla spread open. 3. Stamens, showing the distinct Filaments and united Anthers. 4. Germen, terminated by the Style and Stigma. 5. Ripe Capsule. 


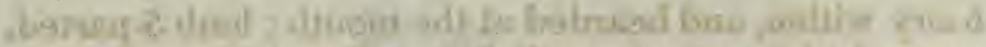

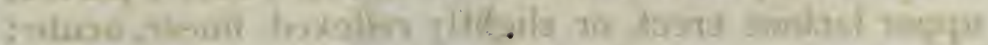

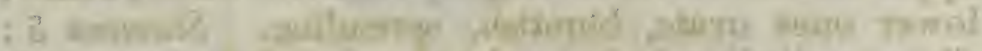

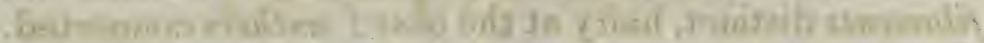

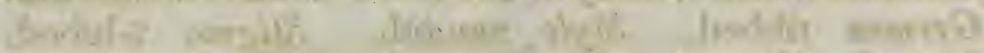

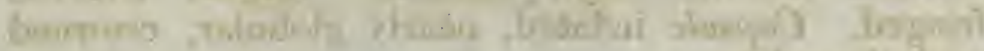
sivlos siltine

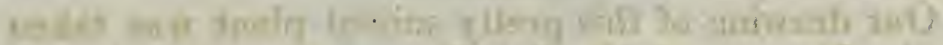

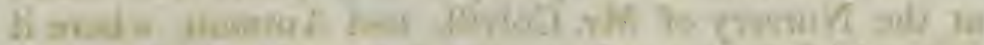

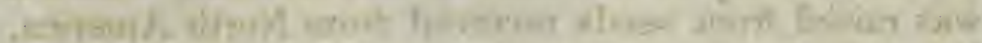

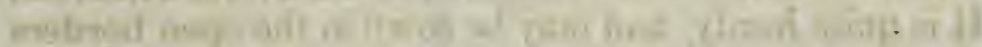

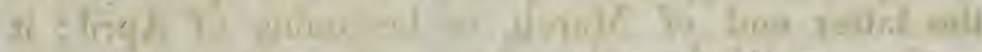

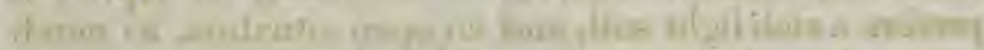

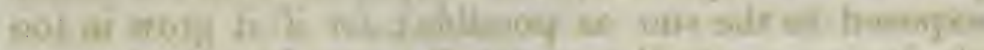

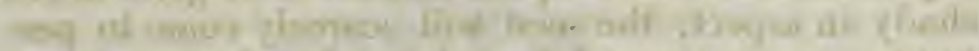

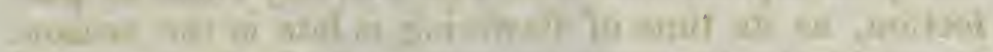

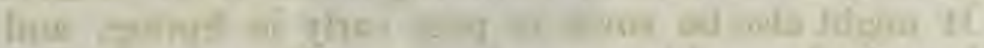

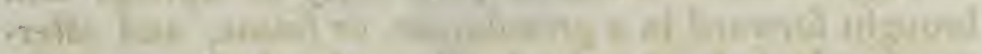

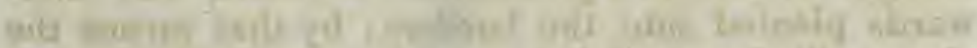

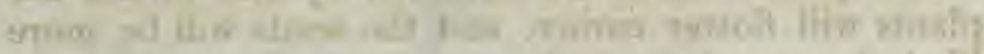

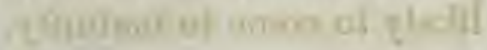

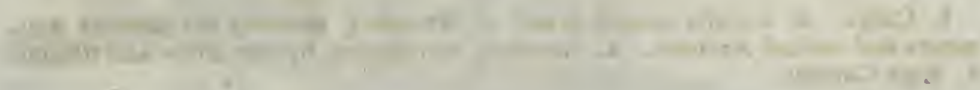




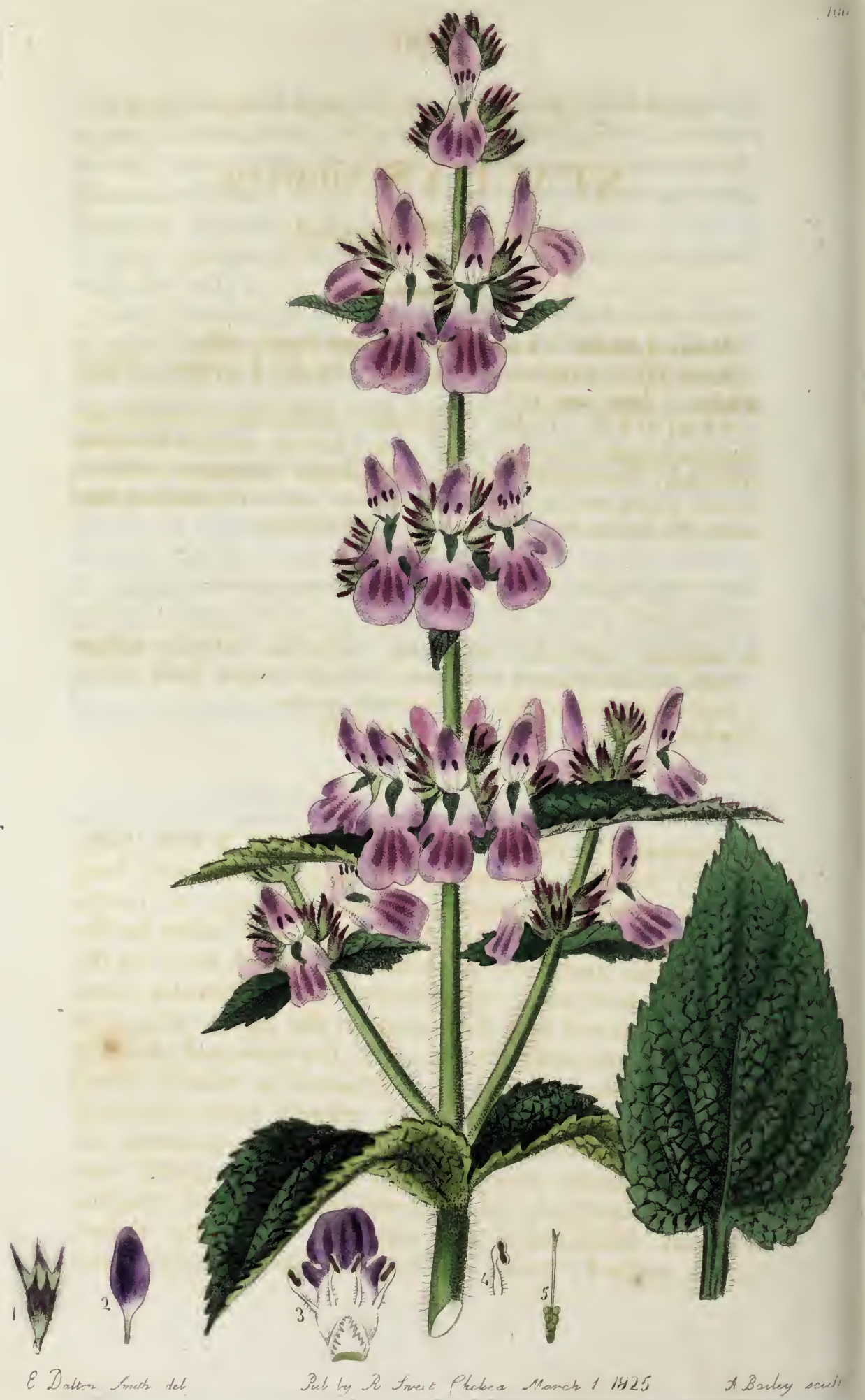




\section{0}

\section{STACHYS sibirica.}

Siberian Hedge-nettle.

Natural Order. La Biate. Brown prodr. 499.

Sect. III. Stamina 4 fertilia. Corolla bilabiata. Calyx 5-fidus. Juss. gen. 112.

STACHYS. Calyx angulatus 5-dentatus acuminatus. Corolla labium superius fornicatum; labium inferius lateribus reflexum; intermedia majore emarginata. Stamina deflorata versus latera reflexa.-Flores axillares aut verticillato-spicati verticillis bracteatis, proximis aut distantibus.

S. sibirica, verticillis multifloris, calycibus subpungentibus, foliis ovato-oblongis acuminatis serratis supra hirtis subtus mollissime tomentosis, caule erecto lanato.

Stachys sibirica. Link enum. 2. p. 109.

Perennial. Stems erect, from 1 to 2 feet high, bluntly 4 -sided, channelled, thickly clothed with long villous down. Leaves opposite, oblong, or ovate, tapering to a point, sharply serrate, very hairy on the upper side, and densely clothed with soft wool on the lower: lower ones cordate at the base. Petioles short, much flattened and furrowed on the upper side, and keeled on the lower, widened at the base and clasping the stem, densely villous. Flowers in whorls round the stem, of a bright lilac: whorls many-flowered. Bractes numerous, unequal, linear, taper-pointed, villous. Pedicles short. C'alyx ringent, angular, ventricose, 5 -toothed, villous, teeth taper-pointed, fringed. Corolla bilabiate, hairy outside; upper lip entire, ovate, arched ; lower one large, 3-lobed, rugose, sides 
reflexed; side lobes short and blunt; terminal one broad, truncate, margins uneven. Stamens 4 , inserted in the mouth, the 2 lower ones rather the shortest: filaments hairy: anthers incumbent. Style smooth, filiform. Stigma bifid, points spreading.

The present subject is a hardy perennial plant, thriving well in the open borders, in the common garden soil, where its abundance of lively blossoms make a handsome appearance; those are produced, in succession, from June to August. It is readily increased by dividing at the root, or by seeds, which ripen plentifully.

Our drawing was taken at the Nursery of Mr. Colvill, last July.

1. Calyx. 2. Upper lip of the Corolla. 3. Lower lip of ditto, showing the insertion of the 4 Stamens. 4. Two Stamens detached, showing the Anthers stuck to each other. 5. The 4 naked Seeds, with the Style, and divided Stigma. 


\section{SYSTEMATICAL INDEX}

Tò

VOLUME I.

1 Ranunculus monspeliacus, v. cuneutus $\quad$........... 94

Pronia lobata............. 70

Pronia paradoxa $\beta$ fimbriuta $\quad \cdots \quad 19$

Glaucium filvum ......... 35

Mathiola tricuspidata........ 46

Schivereckia podolica ...... 77

Iberis Tenoreana $\ldots \ldots \ldots \ldots . .88$

Iberis odorata $\ldots \ldots \ldots \ldots \ldots \ldots, 50$

Malcomia Chia ........... 40

Malcomia littorea .......... 54

11 Hesperis fragrans $\ldots \ldots \ldots \ldots \ldots 61$

12 Viola pedata $\ldots \ldots \ldots \ldots \ldots \ldots \ldots 69$

3 Dianthus latifolius .......... 2

14 Silene vespertina $\ldots \ldots \ldots \ldots \ldots .58$

15 Silene picta $\ldots \ldots \ldots \ldots \ldots \ldots \ldots \ldots .92$

16 Linum alpinum $\ldots \ldots \ldots \ldots \ldots \ldots 17$

17 Malva mauritiana $\ldots \ldots \ldots \ldots . .81$

18 Impatiens biflora $\ldots \ldots \ldots \ldots \ldots 43$

19 Coronilla iberica $\ldots \ldots \ldots \ldots \ldots .25$

20 Orobus albus $\ldots \ldots \ldots \ldots \ldots \ldots \ldots .22$

21 Astragalus tenuifolius ....... 73

Anthyllis montanus $\ldots . . \ldots \ldots$

Baptisia exaltata ...........

Cuphea viscosissima .........

Rhexia mariana $\beta$ rubella ......

Enothera macrocarpa .......

Clay tonia sibirica ..........

Saxifraga ligulata...$\ldots \ldots \ldots$

Richardsonia scabra .........

Centaurea suaveolens ........

Liatris spicata ............

Liatris sphæroidea $\ldots \ldots \ldots \ldots$

Liatris squarrosa ..........

Ammobium alatum ..........

Ageratum mexicanım .......

Coreopsis lanceolata .........

Coreopsis tinctoria ..........

Rudbeckia hirta ...........

Rudbeckia serotina ........

Galinsogea trilobata .........

Chrysanthemum sinense, $v$. involutum

Chrysanthemum sinense, ข. fusciculatum .............

Calendula hybrida ...........

Lobelia inflata ............

Gonolobus hirsutus $\ldots . . . \ldots$.

Phlox triflora ...............

Ipomoa barbigera ...........

Cuscuta verrucosa ...........

Nemopliila pliacelioides

$\cdots$

50 Verbascum pyramidatum......

Hyoscyamus agrestis........ 27

Hyoscyamus physaloides ..... 13

Hyoscyamus orientalis ...... 12

Saracha umbellata ......... 85

Veronica neglecta ......... 55

Teronica latifolia ......... 23

Wulfenia carinthiaca........ 66

Schizanthus pinnatus........ 63

Schizanthus porrigens ...... 76

Mazus rugosus ............ 36

Pedicularis canadensis. $\quad . . .667$

Linaria bipartita ........... 30

Monarda media .......... 98

Salvia Tenorii ............ 26

Phlomis laciniata $\ldots \ldots \ldots \ldots \ldots .24$

Phlomis pungens ......... 33

Stachys sibirica ........... 100

Dracocephalum speciosum $\ldots .93$

Dracocephalum argunense $\ldots .47$

$\begin{array}{lll}\text { Dracocephalum canescens } & \ldots & 38\end{array}$

Scutellaria orientalis $\ldots \ldots \ldots \ldots \quad 45$

Scutellaria alpina $\ldots \ldots \ldots \ldots .90$

Scutellaria Columnæ ........ 52

Primula Palinuri $\quad . . \ldots \ldots \ldots .8$

Soldanella montana $\ldots \ldots \ldots \ldots 11$

Cyclamen vernum ......... 9

Lysimachia verticillata...... 21

Grlobularia vulgaris $\ldots \ldots \ldots \ldots .20$

$\begin{array}{llll}79 & \text { Grobularia vulgaris } \ldots \ldots \ldots \ldots & 20 \\ 80 & \text { Globularia cordifolia } \ldots \ldots \ldots \ldots \ldots & 34\end{array}$

81 Taxanthema tatarica .........

8.2 Oxybaphus Cervantesii ....... 84

4483 Asarum virginicum.......... 18

$48 \quad 84$ Asarum canadense.......... 95

8985 Orchis spectabilis .......... 65

$10 \quad 86$ Hahenaria bracteata ........ 62

7287 Neottia cernua $\quad . . \ldots \ldots \ldots \ldots .42$

8288 Cypripedium parviflorum ..... 80

489 Cypripedium pubescens $\ldots . .7$ 7

5690 Iris hungarica $\ldots \ldots \ldots \ldots \ldots \ldots \ldots .74$

91 Iris verna ... ............ 68

$7 \quad 92$ Iris dichotoma $\ldots \ldots \ldots \ldots \ldots \ldots .96$

93 Renealmia grandiflora $\ldots . . .6 \quad 64$

1494 Muscari botryoides. $a . \beta . \gamma \ldots .15$

39 G5 Hemerocallis disticha $\ldots \ldots \ldots . .28$

9996 Lilium spectabile ......... 75

197 Tulipa pubescens $\ldots \ldots \ldots \ldots \ldots .78$

29 98 Yucca glaucescens.......... 53

8699 Comnelina colestis ........ 3

6100 Symplocarpus fotidus ...... 57 


\section{ALPHABETICAL INDEX}

TO

VOLUME I.

Ageratum mexicanum $\quad . . . . . .$. Ammobium alatum .............. Anthyllis montana........... Asarum canadense ............. Asarum virginicum $\quad . . \ldots \ldots \ldots . .$. Astragalus tenuifolius $\ldots \ldots \ldots \ldots .$. Baptisia exaltata ............. Calendula hybrida .............. Centaurea suaveolens........ Chrysanthemum sinense rar. fusciculatum ................

Chrysanthemum sinense var. involutum (................

Claytonia sibirica $\quad$. $\ldots \ldots \ldots \ldots$

Commelina cœlestis $\quad$..........

Coreopsis lanceolata ............

Coreopsis tinctoria $\quad \ldots \ldots \ldots \ldots \ldots \ldots$

Coronilla iberica...$\ldots \ldots \ldots \ldots \ldots$

Cuphea viscosissima ............

Cuscuta verrucosa .............

Cyclamen vernum ..............

Cypripedium parviflorum .........

Cypripedium pubescens $\ldots \ldots \ldots \ldots$

Datura Tatula................

Dianthus latifolius .............

Dracocephalum argunense ........

Dracocephalum canescens ........

Dracoceplialum speciosum ........

Galinsogea trilobata $\quad . . \ldots \ldots \ldots$.

Glauciunı fulvum .............

Globularia cordifolia ............

Globularia vulgaris $\quad \ldots \ldots \ldots \ldots \ldots \ldots$

Gonolobus hirsutus..............

Habenaria bracteata...$\ldots \ldots \ldots \ldots$

Hemerocallis disticha ...........

Hesperis fragrans ..............

Hyoscyamus agrestis $\quad \ldots \ldots \ldots \ldots$.

Hyoscyamus orientalis ..........

Hyoscyamus physaloides ..........

Iberis odorata..$\ldots \ldots \ldots \ldots \ldots \ldots$

Iberis Tenoreana .............

Impatiens biflora ..............

Ipomœa barbigera .............

Iris dichotoma ................

Iris hungarica $\ldots \ldots \ldots \ldots \ldots \ldots \ldots \ldots$.

Iris verna $\quad . . \ldots \ldots \ldots \ldots \ldots \ldots \ldots . . .$.

Liatris sphæroidea.............

Liatris spicata..$\ldots \ldots \ldots \ldots \ldots \ldots$

Liatris squarrosa ...............

Lilium spectabile $\ldots \ldots \ldots \ldots \ldots \ldots$.

Linaria bipartita ..............
89 Linum alpinum ................

Linum alpinum ......

Ly

ysimachia verticillata $\ldots \ldots \ldots \ldots \ldots 21$

Malcomia Chia .............. 40

Malcomia littorea ............ 54

Malva mauritiana ............ 81

Mathiola tricuspidata ......... 46

Mazus rugosus ................. 36

Monarda media .............. 98

Muscari botryoides. $\alpha . \beta, \gamma_{\bullet} \ldots \ldots \ldots \ldots 15$

Nemophila phacelioides ........ 32

Neottia cernua ................ 42

Enothera macrocarpa .......... 5

Orchis spectabilis $\quad \ldots \ldots \ldots \ldots \ldots 65$

Orobus albus ................ 22

Oxybaphus Cervantesii $\quad \ldots . \ldots \ldots .84$

Pronia lobata................ 70

Pæonia paradoxa $\beta$. fimbriata ..... 19

Pedicularis canadensis $\ldots \ldots \ldots \ldots \ldots 6$ 67

Phlomis laciniata ..............

Phlomis pungens $. \ldots \ldots \ldots \ldots \ldots \ldots . .33$

Phlox triflora ................ 29

Primula Palinuri .............. 8

Ranunculus monspeliacus $\beta$. ouneatus 94

Renealmia grandiflora .......... 64

Rhexia mariana $\beta$. rubella $\ldots \ldots \ldots .41$

Richardsonia scabra ............ 91

Rudbeckia hirta..$\ldots \ldots \ldots \ldots \ldots \ldots .82$

Rudbeckia serotina $\quad \ldots \ldots \ldots \ldots \ldots$ 4

Salvia Tenorii $\ldots \ldots \ldots \ldots \ldots \ldots \ldots .26$

Saracha umbellata ............. 85

Saxifraga ligulata ............. 59

Schivereckia podolica $\ldots \ldots \ldots \ldots \ldots \quad 77$

Schizanthus pinnatus $\ldots \ldots \ldots \ldots \ldots 63$

Schizanthus porrigens $\ldots \ldots \ldots \ldots \ldots 76$

Scutellaria alpina ............. 90

Scutellaria Columnæ $\quad \ldots \ldots \ldots \ldots \ldots .52$

Scutellaria orien talis ........... 45

Silene picta..$\ldots \ldots \ldots \ldots \ldots \ldots \ldots \ldots .92$

Silene vespertina $\quad$.......... 58

Soldanella montana ............ 11

Stachys sibirica $\quad \ldots \ldots \ldots \ldots \ldots \ldots 100$

Symplocarpus fotidus $\ldots \ldots \ldots \ldots \ldots 57$

Taxanthema tatarica ........... 37

Tulipa pubescens ............. 78

Verbascum pyramidatım ........ 31

Veronica latifolia .............. 23

Veronica neglecta .............. 55

Viola pedata $\quad . . \ldots \ldots \ldots \ldots \ldots \ldots .69$

Wulfenia carinthiaca $\ldots \ldots \ldots \ldots \ldots 66$

Yucca glaucescens .............. 53 


\section{ENGLISH INDEX}

To

\section{VOLUME I.}

Adam's-Needle, glaucescent $\quad \ldots$ r. Ageratum, Mexican $\quad . . . . . . .$. . Ammobium, winged-stalked ...... Asarabacca, Canadian ............. Asarabacca, Virginian ............. Baptisia, tall upright $\quad . . . . . . . .$. Bitter-Vetch, white-flowered ....... Candy-tuft, sweet-scented ......... Candy-tuft, Tenore's ............. Catchfly, evening ................ Catchfly, painted-flowered ...... Chrysanthemum, curled lilac ...... Chrysanthemnm, superb clustered yellow ................

Claytonia, Siberian $\quad . . . . . . . . .$.

Commelina, sky-blue $\quad . . . . . . .$. .

Coreopsis, dyeing, or Arkansa ....

Coreopsis, spear-leaved ..........

Coronilla, Iberian ..............

Crowfoot, wedge-leaved Montpelier

Cuphea, viscous ............... Cuscuta, warted-calyxed Nepaul .. Cyclamen, vernal........... Day-Lily, fan-like .............. Dragon's-head, beautiful .......... Dragon's-head, Fischer's ........... Dragon's-head, hoary-leaved ...... Flax, Alpine $\quad . . . . . . . . . . . .$. Galinsogea, three-lobed ......... Globularia, common or blue daisy .. Globularia, wedge-leaved........... Gonolobus, hairy $\quad . . . . . . . . .$. .

Habenaria, long-bracted ........... Hedge-nettle, Siberian ............ Henbane, Hungarian field ......... Henbane, oriental .............. Henbane, purple-flowered ........ Horned-Poppy, orange-coloured ... Ipomoea, bearded-calyxed ......... Iris, forked petaled............ . Iris, sickle-leaved Hungarian ....... Iris, vernal American ............ Kidney-Vetch, mountain ........... Ladies'-slipper, small-flowered .... Ladies'-slipper, yellow-downy....... Liatris, globular-cupped ......... Liatris, long-spiked ............. Liatris, squarrose-cupped.......... Lily, showy Siberian ........... Lobelia, bladder-podded ........... Loose-strife, whorled ............
Lychnidea, pubescent-stemmed .... Malcomia, dwarf branching ...... Malcomia, tomentose ........... Mallow, Ivy-leaved ............ Marygold, great Cape ........... Mazus, China $\quad$............... Milk-vetcl, narrow-leaved ........ Monarda, bright purple .......... Mullein, pyramidal ............. Muscari, grape ............. 15 Nemophila, Phacelia like......... 32 Neottia, nodding-flowered ....... 42 Enothera, large-capsuled ....... 5 Orchis, showy American ........ 65 Pæony, double fringed .......... 19 Prony, lobed-leaved .......... 70 Pedicularis, Canadian ......... 67 Phlomis, jagged.leaved......... 24 Phlomis, pungent bracted $\ldots . . . .33$ Pink, broad-leaved ............ 2 Primrose, unequal-bracted ....... 8 Rattlesnake's-master ........... 44 Renealmia, largest flowered ..... 64 Rhexia, Maryland, stained variety •. 41 Richardsonia, rough-leaved ....... 91 Rocket, evening scented ........ 61 Rudbeckia, great hairy $\ldots \ldots \ldots \ldots .82$ Rudbeckia, late flowering '....... 4 Sage, Tenore's ............... 26 Saracha, umbel-flowered ......... 85 Saxifrage, fringe-leaved Nepaul.... 59 Schivereckia, canescent $\ldots \ldots \ldots \ldots .77$ Schizanthus, spreading.......... 76 Schizanthus, winged-leaved $\ldots \ldots \ldots 63$ Sea-Lavender, Tartarian ........ $\mathbf{3 7}$ Skull-cap, Alpine ............. 90 Skull-cap, Colnmna's $\ldots \ldots \ldots \ldots \ldots .52$ Skull-cap, yellow.flowered ....... 45 Soldanella, mountain $\ldots \ldots \ldots \ldots \ldots 11$ Speedwell, broad-leaved ........ 23 Speedwell, canescent $\ldots \ldots \ldots \ldots \ldots .55$ Stock, three-forked ........... 46 Sultan, yellow sweet or Centaury $\ldots \quad 51$ Symplocarpus, fœetid or Scunkweed 57 Thorn-apple, pale blue ......... 83 Toad-flax, cloven flowered ....... 30 Touch me not, two-flowered ..... 43 Tulip, pubescent stalked ......... 78 Umbrella-wort, Cervantes' ....... 84 Violet, cut-leaved ............. 69 Wulfenia, Carinthian $\ldots \ldots \ldots \ldots \ldots 66$ 


\section{ERRATA.}

No. 6, over leaf, line 6 from the bottom, for " an hardy annual," read " a hardy annual."

No. 28, line 12 from the bottom, for "Thumb." read "Thunb."

No. 85, line 14 from the top, for " mosnp." read " monsp." line 17, for " Jacq. schocebr." read " Jacq. schonbr."

No. 94, line 6 from the bottom, 'for "Besl. syst.", read "Besl. eyst." 





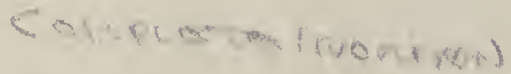

\pm Vols.

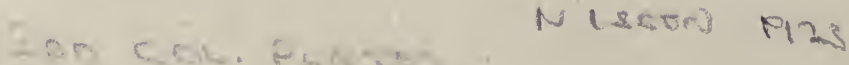


SPECIAL $84-B$

$$
\begin{aligned}
& 5287 \\
& V .1
\end{aligned}
$$

GETTY CENTER LIBRARY 


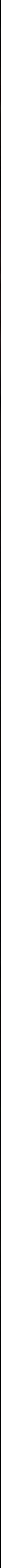

